
$6 x^{\circ}$

- 8

$\left(20^{x}\right.$

$10^{\circ}$

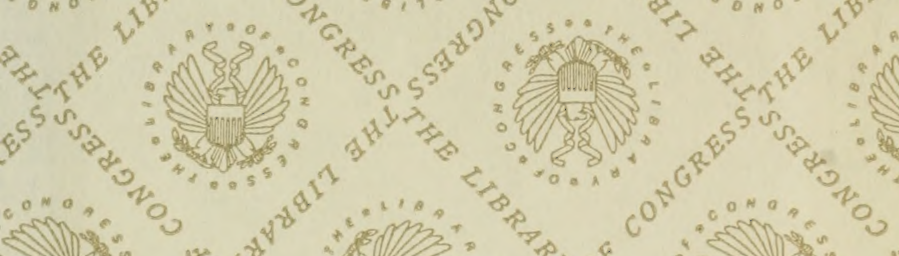

간:

"

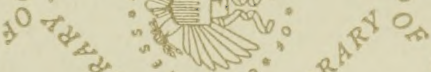

:avet:<smiles>[CH]</smiles>

in
(1)

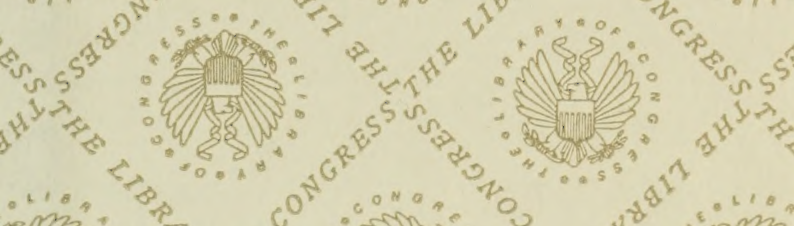

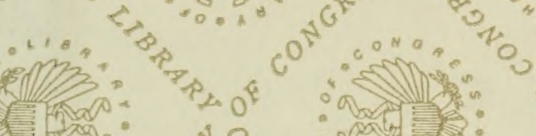

(n):

a 40

ant

- Ids

$0^{\circ} 0^{\circ}+\beta^{3}$

(1)

50

(in

${ }_{11} 0^{3}+0^{3}$

"थ

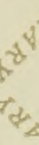

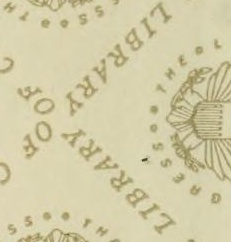

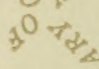


…

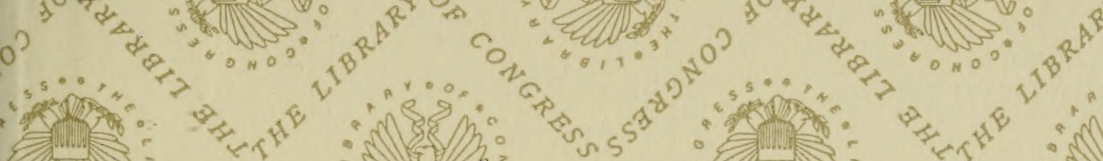
1.

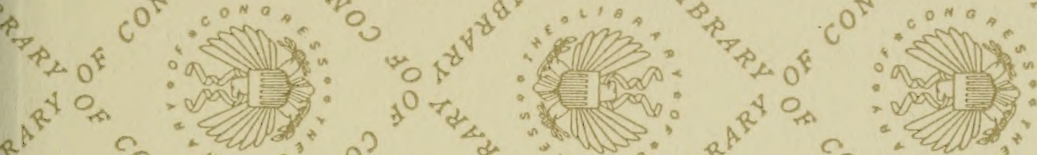

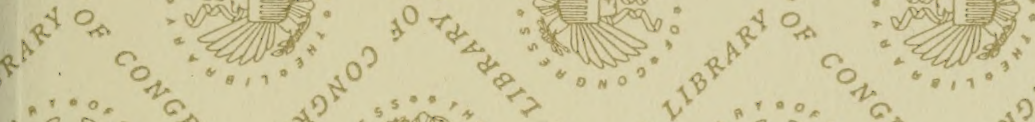
0
0

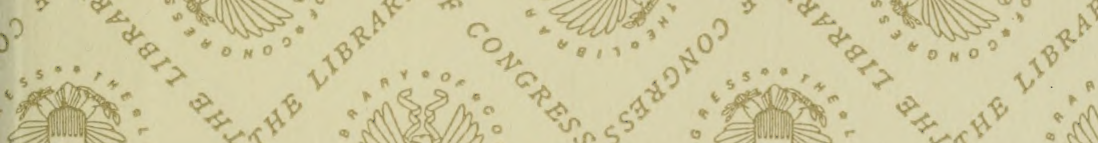
1)

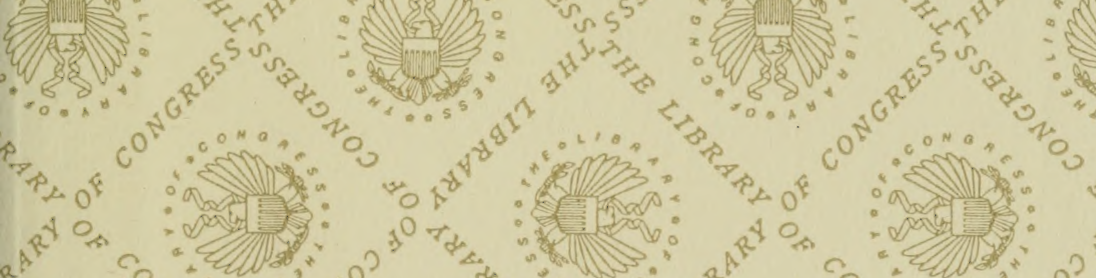

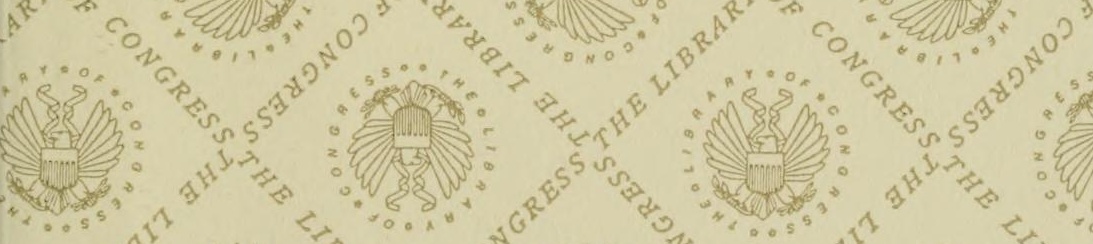

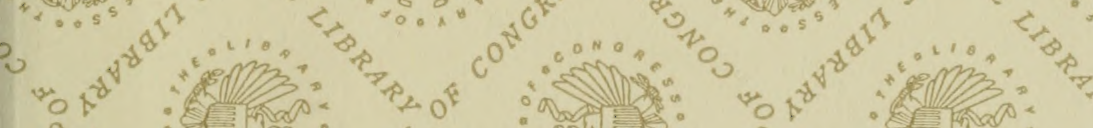

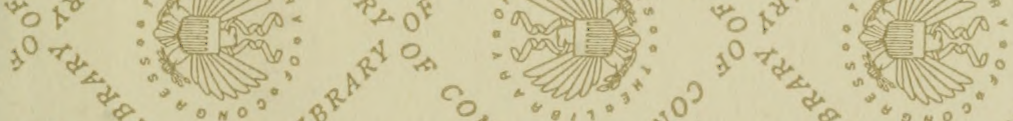

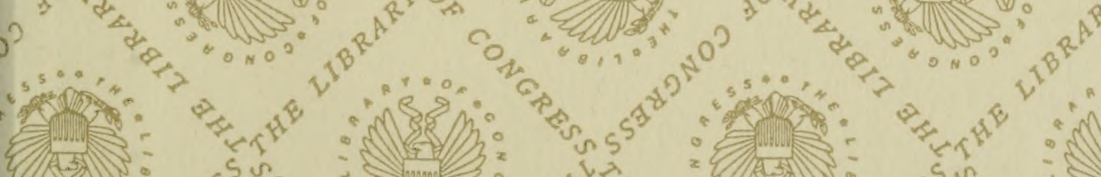

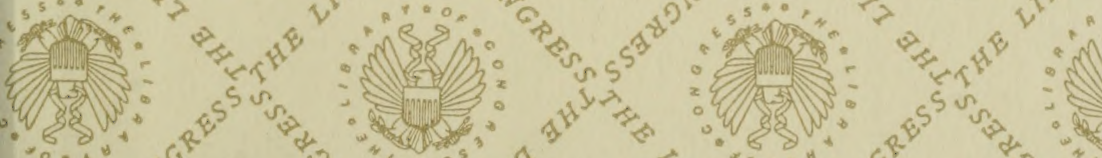







\section{THE BOYS' BOOK OF HUNTING AND FISHING}





\title{
THE BOYS' BOOK OF HUNTING AND FISHING
}

PRACTICAL CAMPING-OUT, GAME-FISHING AND WING-SHOOTING

\author{
BY \\ WARREN H. MILLER \\ Editor of Field and Stream \\ Author of "Chap Chaft," etc.
}

FOREWORD BY DAN BEARD

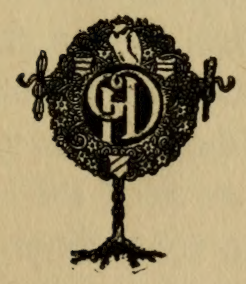

NEW YORK

GEORGE H. DORAN COMPANY 


\section{$s k^{33}$}

Copyright, 1916, By George H. Doran Company

Printed in the United States of America COPYRIGHT, 1914, 1915, BY THE BOYs' MAGAZINE 


\section{FOREWORD BY DAN BEARD}

Any sport which tends to keep our boys in the open is undoubtedly a good thing for the coming generation. The rod and the gun are neither of them instruments for indoor use, consequently a book devoted to the proper use of rod and gun is a book which tends to send our young people to the field, the forest, the river, and the lake; which tends to brighten their eyes, strengthen their muscles, and to quicken their perception and their selfreliance.

We must remember that all boys-yes, every one of them-will pick up the first firearm that comes within reach, and the danger of such an act is in proportion to the amount of their previous study and training in the handling and use of firearms. A well written book on the subject of the gun and rod is a much safer guide than the personal direction of some one who does not know. Almost all the deplorable accidents with firearms are the result of lack of proper training among those who use these weapons.

An amusing incident, which occurred at my log house on the shores of Big Tink in the mountains 
of Pike County, Pa., illustrates the attitude of all good sportsmen toward an untrained man or toward a man whom they do not know.

Two men, both trained woodsmen and crack wing shots but strangers to each other, were my guests. Upon their arrival I informed them that the venison was about gone and that there was but one ruffed grouse left hanging in the gallery, adding that if they wanted a good dinner they had better take their guns and dogs and hustle for it.

Never shall I forget the suspicion with which these men regarded each other and the searching looks which passed between them as the old-timers started away through the woods; how they watched each other like two feudists waiting for an opportunity to kill. Each well knew the danger incurred in going afield with a chump and a gun. I enjoyed watching them for I had often hunted with each of them and I knew that they would not find one another wanting. Sure enough when they came back from the hunt, loaded with game, they came arm in arm. They had gained mutual confidence and a new but warm friendship.

It is only a few days ago since the author of this book with his young son visited me at my log house at "Pike," as we all call it, and any one who had seen Mr. Miller casting on the lake would at once 
have recognised the fact that he was an adept, also any one who had seen his small son casting with the skill of a veteran would have been impressed with the fact that the author of this book is not only an adept himself but also a practical and capable instructor.

Furthermore, any one who had watched the boy, with his quick, self-reliant movements, his erect carriage, clear eyes, and manly bearing could not but have been impressed with the great value of outdoor training. The boy himself is a better preface to this book than I can write.

After all is said and done there is but one excuse for the men of to-day living in this world and that is to prepare the boys, the men of to-morrow, to run the world better. For, if the men of to-day are honest, they must confess that they have been guilty of some fearful and frightful bunglings in managing the world's affairs.

Some years ago in writing for boys I invented the phrase "the boys of to-day are the men of tomorrow," and the immediate use of that phrase by public men in sermons, editorials, speeches, and essays all over the English speaking world is the best guarantee that men realise the immense value of constructive character building work among boys. 


\section{FOREWORD}

Any one who will attend a banquet of lawyers, doctors, merchants, or politicians and look over the faces and bodies of the men he sees before him and then look over the faces of the men at a banquet of the Camp Fire Club of America cannot but be impressed with the difference in the appearance of the men, a difference which forcibly emphasises the beneficial effect of an outdoor life. In the Camp Fire Club of America there are lawyers, doctors, merchants, and politicians but they are of the outdoor type and the difference is so great between them and the ordinary city men that all guests at the speaker's table of the club are struck with wonder and admiration for the crowd assembled on Camp Fire Night.

Then let us give our boys an outdoor life, give them an opportunity to go to the open for their games and recreation, and I know of no better way to stimulate a desire for this than to put into their hands books of the outdoor world, books such as Mr. Miller writes.

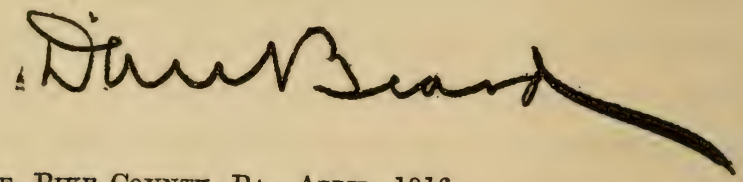

Log House, Pikn Countr, PA., Aprit, 1916. 


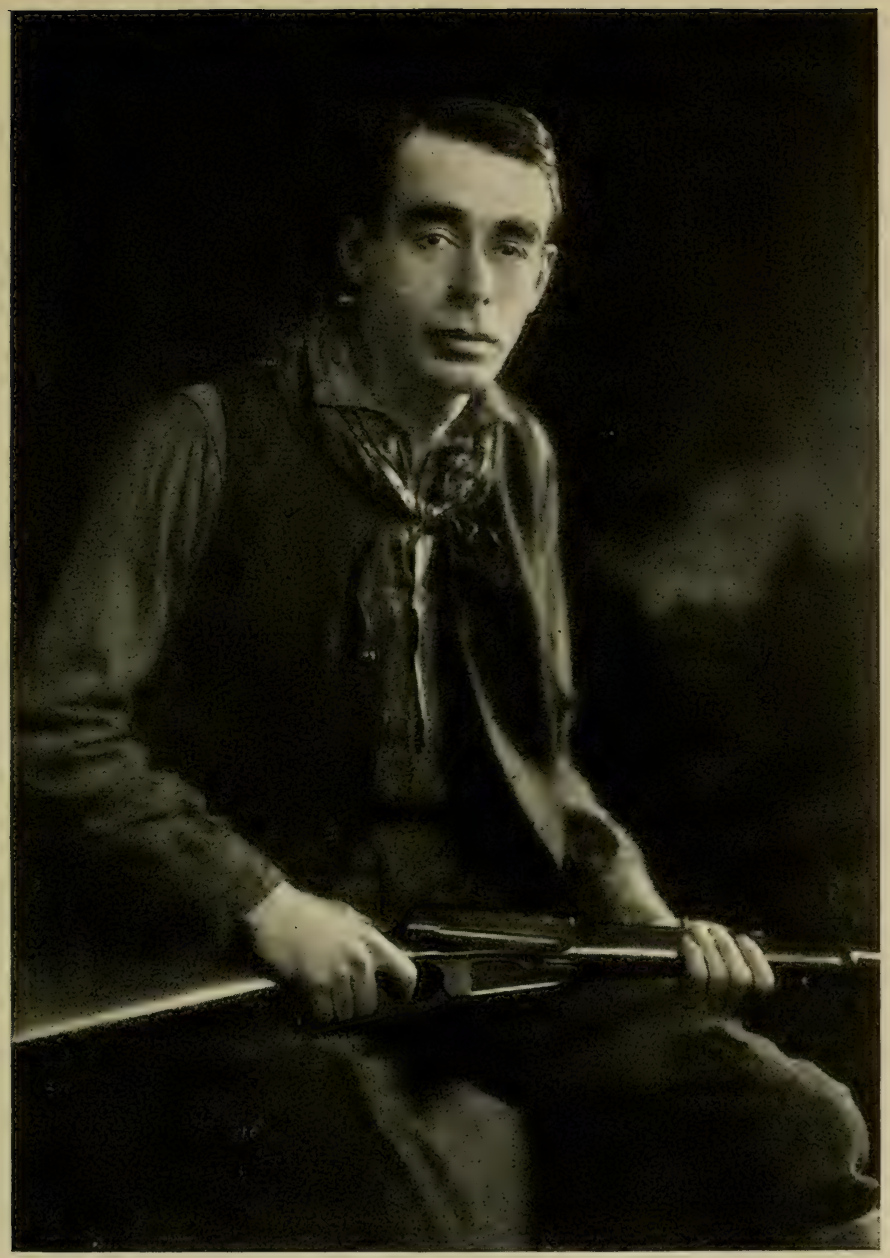

WARREN H. MILLER

Editor, Field and Stream 



\section{AUTHOR'S PREFACE}

"The Boys' Book of Hunting and Fishing" was written because there seems to be no book now in print which will tell the youth of twelve to eighteen years age how to start right in learning these fine arts of the outdoors, and how to get tackle and equipment which will not be out of reach of a young fellow's pocketbook, yet will be just the right thing for the beginner, honestly made, not having perhaps the wearing qualities of more expensive outfits, but efficient and capable for the purpose-which most cheap goods are not, from the very start!

The boy's books of the woodcraft type do not fulfil this requirement, for they stop just where the growing boy wants information; they tell him all about wooderaft and nothing about the right tackle to get and how to use it for trout and bass; nothing on how to learn to be a good wing shot and what guns and gauges to start in with; and little on how to camp out for weeks at a time with a light yet comfortable outfit, and one that will not make them liable to cold from exposure, or sick- 
ness from improper food. The men's books on camping, fishing and wing shooting cover these subjects thoroughly, but they suggest outfits that are altogether out of the financial means of any. but rich boys, and no fellow has a right to ask his father for equipment that costs far more than the presents that his brothers and sisters get, and that father himself, perhaps, can hardly afford to purchase. Yet there is good cheap equipment,-good enough for any beginner, man or boy,-on the market, but you must know what to look for to seek it out.

Again, most boys like to make their own outfits from the raw material, as being cheaper and adding zest to the game, particularly in camping outfits. The author has camped, fished and hunted since a boy of ten, and, having been so poor that nearly all his own outfits of that date had to be made by himself, has borne this well in mind in penning the chapters of this book.

It will be noted that the chapters on hunting are almost exclusively wing shooting, only one chapter on the rifle being included. My reason for this is that the shotgun is not only the most suitable weapon for boys, as being safer and more capable of getting game within a boy's reach, but proficiency in the use of the shotgun is the best possible 
training for skill in the use of the rifle in shooting big game. Military shooting, as it is now practised, is based on an entirely different set of conditions than big game shooting. The latter is practically wing shooting with the rifle, where a quick, accurate sight at bounding big game, going at full speed, must be taken and a hit scored. It has been the author's experience that boys under the age of eighteen have not the development and endurance needful for the hunting of big game, while, on the other hand, they can become quite as skilful as the men in upland and marsh bird shooting. The rifle, however, that boys can become intimately familiar with and masters of, is the .22 and its near relatives and cousins-rifles of comparatively low power but extreme accuracy. Such game as woodchuck, fox, rabbit, squirrel, etc., is fair game for the boy with his rifle, and skill in its use should be attained between the ages of twelve and sixteen years.

Again let me reiterate that this book is written with the poor boy in mind. There is a tremendous amount of shoddy outdoor goods on the market, and the average salesman unloads it on the innocent and confiding boy, who trusts him implicitly and parts with his hard-earned pennies for tackle and equipment that is entirely unsuitable 
for real game fish or real camping or wing shooting. While it has not been possible to name brands of rod, reel, line and lure as good yet cheap, I have given specifications which are met by goods now offered for sale at a low price by reliable houses, and it is up to the boys themselves to ferret out the goods. Knowing just what you want, and about what you ought to pay, it ought not to be hard to select outfits that will start you right. The rest is practice-and enjoyable practice, too-the only school of which you will never tire, if you live to be ninety years young!

INTERLaken, N. J., AprIL, 1916. 


\section{CONTENTS}

PART ONE: ANGLING FOR BOYS

CHAPTER

I Battling Bass and Will Trout . . . . 21

II The Tackle to Get and How to Use It-

Black BASS . . . . . . . 30

III The Tackle to Get and How to Use It-

Fly Casting for Trout . . . . . 41

IV Kinks on Catching Game Fish . . . . 49

PART TWO: SHOOTING FOR BOYS

I First Lessons with the Hand Trap . . 59

II Choosing a Gun . . . . . . . .

III The "Ping Pong" TraP . . . . . . 77

IV Practice with the Standard Trap . . 85

iV The Swift and Spiteful Twenty Gauge . 92

VI The First Day at the Gun Club . . . 103

VII A DAY IN the Uplands . . . . . . 114

VIII Shore Bird Shooting . . . . . . 127

IX Duck Shooting-Anticipation . . . 148

X Duck Shooting-Realization . • . 155

XI A Chapter on the Rifle . . . . . 162

$$
\text { xiii }
$$


xiv

\section{CONTENTS}

\section{PART THREE: CAMPING FOR BOYS}

OHAPTER

I Boy Camps of Long Ago . . . . . 185

II HIKING * . . • . • • • . • 196

III The Hunting and Fishing Camp • . . 204

IV CAMP COOKert . . . . . . . . . 216

$\nabla$. All About the Different Tents . . . 229

VI Camp Fires . . . . . . . . . . . . 241

VII WOODSMANSHIP . . . . . . . . . 254

VIII Living OFF the Forest • . . • • . 269

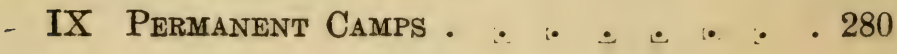




\section{LIST OF ILLUSTRATIONS}

Warren H. Miller, Editor Field and Stream . . ix His Luck . . . . . . . . . . . 22 Chums • • • . • • • • • • • • 24 An Eight-Pound Large Mouth Bass . . . . . 24 A Typical Mountain Brook Trout Stream . . . 28 Bully Good Bass Water . . . . . . . . 32

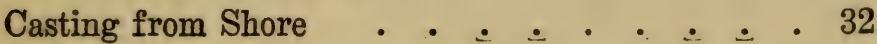
Bait Casting Rods . . . . . . . . . . 34 Bait Casting Reels . . . . . . . . . 34

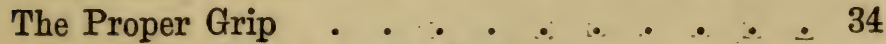
Landing a Pike on the Fly Rod . . . . . . 36

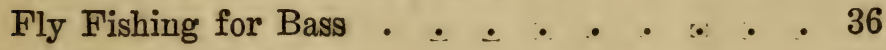
Fly Fishing Tackle . . . . . . . . . . 44 Eastern and Western Brook Trout . . . . . 46 Deep Water Trout Fishing . . . . . . . 50 A Boy Muskallonge Fisherman $\bullet . . \quad . \quad . \quad 52$

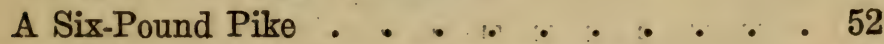
Some Prizes for the Bait Casting Outfit . . . . 54 The Hand Trap and Single-Barreled Shot Gun . 60 The Proper Straight Stock . . . . . . . เ. 72 A Comparison in Gun Sizes . . . . . . 72 Breaking Them . . . . . . . . . . 88 First Lessons in Wing Shooting . . . . . . 94 
A Boy's Gun Club at Practice . . . . . 106 Pepper and the Kid Starting for a Rabbit Hunt . 116 Our Beagles and Some Rabbits . .. . . 116 A Setter, Pointing a Bevy of Quail . . . . . 116 The Ruffed Grouse . . • . . . . . . . 124 The Pointer . . . . . . . . . . . . 124 Snipe Decoys Set Out . . . . . . . . 132 The Kid and Some of His Plover . . . . . 132 An Alligator Hunt . . . . . . . . . 132 Making Good at Trapshooting . . . . . . 150 Broadbill Decoys Anchored Off a Point . . . 158 A Mallard Hide in the Wild Rice . . . . . 158 Throwing Out the Decoys . . . . . . . 158 The Most Popular BigsGame, the White-Tailed Deer 164 Some Fine Wyoming Elk . . . . . . . . 170 The Author and His Cowboy Chum in Camp in Montana

Bringing Out Your Moose Head . . . .. . . 170 The Pendulum Deer Target \& . . . . . . 174 Some .22 Repeating Rifles . . . . . . . 176 Some .22 Single Shots . . . . . . . . . 176 The King of American Predatory Game . . . 180 The Old-Fashioned Heavy Wall Tent, with

Fly . . . . . . . . . . . . . . 190 The Author's Tent Home-Made When He Was a

Boy of Twelve Years . . . . . . . . 190 The Dan Beard Tent . . . . . . . . 198 The Forester Tent . . . . . . . . . 198 A Camping Outfit for Boy's . . . . . 208 


\section{ILLUSTRATIONS}

xvii The Author's Perfect Shelter Tent . . . . . 214 Off for a Week's Camp . . . . . . . . . 214 The Boy Scout Cook Kit . . . . . . . 222 The Stopple Cook Kit . . . . . . . . . 222 The Forester Cook Kit . . . . . . . . . 222 An Encampment of the Camp Fire Club . . . 234 In Camp in a Forester Tent . . . . . . 234 The Western Miner's Tent . . . . . . 234 The Indian Fire . . . . . . . . . . . 246 The Nessmuk Backlog Fire . . . . . . . 246 The Indian Teepee . . . . . . . . . . 274 A Primitive Cook Kit . . . . . . . . . 275 

PART ONE: ANGLING FOR BOYS 



\section{THE BOY ' BOOK OF HUNTING AND FISHING}

PART ONE: ANGLING FOR BOYS

\section{CHAPTER I}

BATTLING BASS AND WILY TROUT

Two boys went fishing in a mountain lake, located-well, anywhere from Maine west to Wisconsin and south to Virginia and Kentucky-take your choice! It was a lake with lily pads and tree stumps along its shores, and there were woods along the banks to camp in, with maybe a circle of forested hills surrounding it. One boy had his boat anchored out near a little rocky islet, and was still-fishing in eight feet of water with a worm, a dobber and a cane pole for big sunnies and perch. The other had a canoe and was paddling slowly along the shores, just outside the lily pads, and casting his lure at likely looking places where game fish might lurk. He possessed a wonderful accuracy with that rod and lure, and at nearly every cast sent it true to the chosen spot, maybe forty, fifty or sixty feet away, to some small bay 


\section{ANGLING FOR BOYS}

in the lily pads or quiet pool in front of a stump sometimes no bigger than a straw hat.

Presently the boy in the boat got a bite. A decided jiggle dipped his float and then it went under completely. He gave the pole a yank, and in a few seconds brought up a large orange-bellied sunfish weighing maybe half a pound, which came flopping over the side and was soon seized and strung with a lot of others on a fish line dangling over the side. The boy in the canoe went on casting. His lure sailed out and landed-ker chunk! right into the lair of a foxy old black bass. The boy started reeling it back when suddenly there was a furious splash, the water boiled around the lure and instinctively the boy struck. Instantly the old demon leapt clear out of water, shaking his head in a frantic effort to throw the lure; the boy gasped with excitement, but in the rush that followed his fingers were barked by the spinning reel handle and the bass would have gotten away except for the boy's ready left thumb which was braking hard on the reel spool. Then the bass turned and rushed towards the boat, while the boy grabbed the reel handle and reeled in line furiously, for to give that fish a single foot of slack meant to lose him. Under he went, straight under the canoe, but again the boy was master, for, giv- 


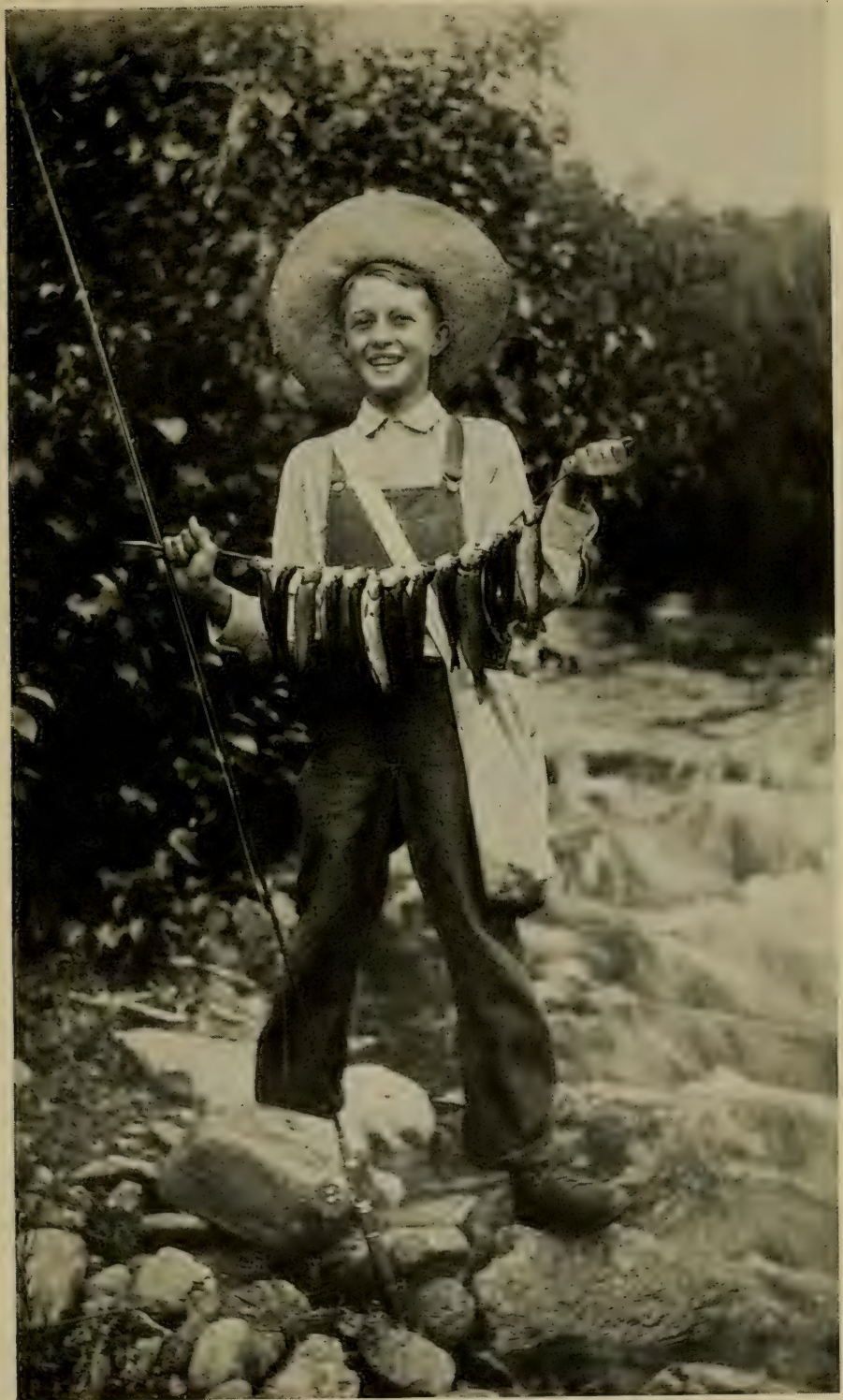

"HIS LCCK"

Taken on an inexpensive fly fishing outfit. Note, however, that reel is on wrong end of butt for good balance. 



\section{BASS AND TROUT FISHING 23}

ing him line as he thumbed the reel, the boy dexterously turned the canoe with his paddle, bringing the bass beyond the boat again and going strong, evidently bound for some hidden snag that he knew of where the line could be tangled up and broken. This would never do, so setting back hard on the rod the boy opposed its full strength to the bass' tactics and soon turned him. This time he came up to the surface with a magnificent splash and the boy's heart pounded wildly as he dipped the rod tip and pulled him down again.

"Jingo! another like that and he's off! Go it, you beauty!" he exclaimed exultingly. Again the bass started for the canoe, this time near the surface, the boy reeling like mad, and, taking advantage of the fish's momentum, he gave the rod a flip and the next instant the big bronze and green fellow was thrashing wildly about in the bottom of the canoe while the boy grabbed him in both hands. "Gee! He'll go three pounds! Some battle! Eh, what!" he whooped, holding him up by the gills. He despatched the bass mercifully with his hunting knife, tied him through the gills to the canoe cross bar and resumed his casting.

Now, which of those boys would you rather be, the one indolently watching a float and now and 
then pulling up a half-pound sunfish or perch, or this one who had learned the angler's art of bait casting and has been rewarded by a thrilling battle with a big game fish. You can become either. Age has got nothing to do with it for the boy that had the battle with the bass was ten years old. I know him well; in fact, he is my own son. The other boy was thirteen but the lily pads meant nothing to him-that kind of fishing he thought was for men, he was going after sunnies and perch, even in the very lake where he knew bass and pike and pickerel were to be caught-IF one knows how!

Pocket book has little to do with it. The rod, reel and line used by the boy who caught the bass cost, all together, under three dollars; he got the reel for his Christmas present (it cost Santa Claus about two dollars) ; the rod came with a subscription to a certain sportsman's magazine (it has landed a 21-pound muscallonge), and the line was the only thing he had to save up his allowances for. It cost 75 cents for 50 yards of it. Surely anything that will put you in the way of having all that sport is worth saving up for to buy the necessary tackle.

After getting the equipment the boy had to put in many an hour learning, first how to cast with- 


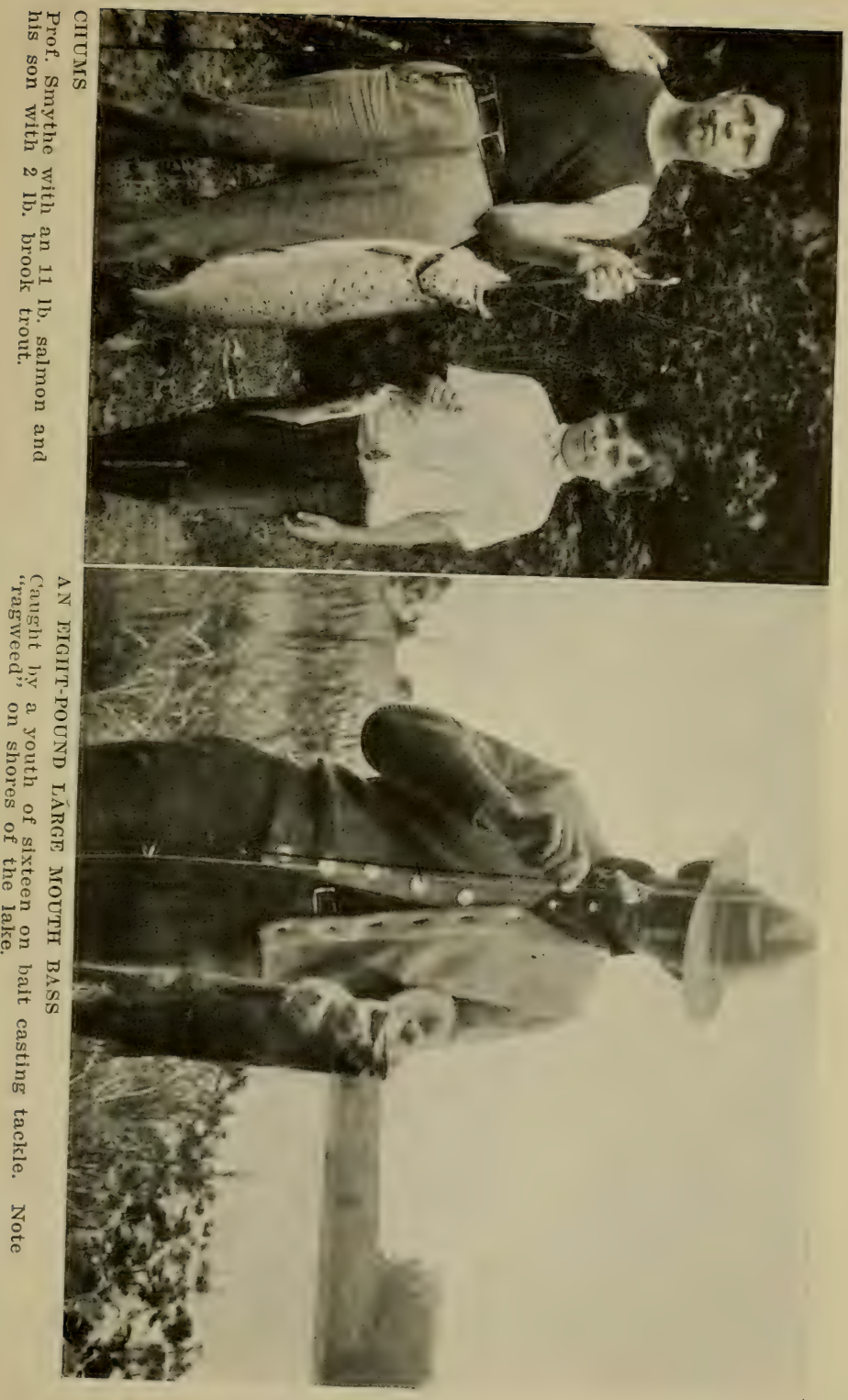



out back lashing or snarling up the line with the reel, and second, how to get sureness and accuracy so as to land the lure on any spot desired even if as much as eighty feet away. And learning this is good fun for any boy, as much fun as shooting a rifle, for every cast is target practice of a high order, and to learn the game you have to get into a boat and row along casting as you go, at first with a discouraging period of dubbism and finally "arriving" at a reasonable proficiency, after which perfecting yourself in the art is a rare pleasure.

In a word, the difference between the boy catching sunnies and the one bait casting for bass is that one is just a fisherman and gets relatively little fun out of it, while the other is a sportsman; he has acquired a fine and difficult art and he gets the thrill and excitement of many tussles with real game fish. Too difficult for a boy? Pshaw! Give him a chance and the proper rig and he will do as well as the men; look at the boys of seven to fifteen, and girls even, who win prizes with rig game fish in the Juvenile Classes of the Field and Stream Prize Fishing Contest, held every year during the whole open season for bass, trout, muscallonge and pickerel.

It's up to you; bait casting and fly casting are 
no more difficult to learn than good baseball, tennis, sailing, football-any of the outdoor sports which boys take to as a matter of course, as soon as they get out of tops and marbles. It is the object of these chapters to tell you what to get and what to avoid, how to learn to use rod and line, and what tactics have to be used in hooking and landing the bulldog bass, the gamey trout, the wolfish pike and that tiger of the inland lakes, the muscallonge. When twelve-years-old Jack White, the boy who goes fishing with Will Dilg, one of America's greatest bass fishermen, landed a twelvepound musky alone and unaided, he certainly showed that none of our game fish are beyond the reach of any boy's angling ability, provided that he keeps a cool head and plays the game according to the rules.

Let us move the scene a little further north, into the home of the trout, though bass and trout waters do overlap to a certain extent. The family goes to the mountains for the summer and you, the boy, are with them-you bet! There are walks to take and waterfalls to see and there is lots of tennis, with maybe some baseball. But you get tired of batting a ball over a net-a sort of hard work that gets nowhere-and you long for some real sport. Aha! a trout stream in the vi- 
cinity, three miles away between Hawk Mountain and Old Baldy! Do you cut an alder pole, dig up some worms, buy five cents' worth of line and a hook and go after them? No-by ginger, no! You have a 5-ounce fly casting rod, thirty yards of $\mathrm{E}$ line, a single click reel, some leaders and a few flies, say those old reliables-Parmacheene Belle, Coachman, Cow Dung, and Silver Doctor, and you put up a lunch and hike for that stream just as early as you can bolt a breakfast. Arrived there you know very well that that old worm and pin hook dodge won't work; these trout know far too much to go hang themselves on the first halter let down to them with a worm on it! Rather you keep out of sight and fish each pool upstream, because you know that the trout lie with their heads upstream and cannot see back of them for a space covering an angle of about 30 degrees each way from their dorsal fin. You joint up the rod, put on the reel and string the line through the guides. Next the leader, already wetted and pliant, is tied on and finally a fly, fished dry or wet according to the water. You choose a fly resembling as nearly as possible the insects hovering over the stream, and then you are ready to cast. Look for a clear back cast, making sure that no overhanging boughs are going to snare your fly, and then start 
getting out line. Each "false" cast, that is, a cast in which the fly is not allowed to drop in the pool, gets the fly out further and further as you strip line from the reel. Now you begin working the cast over some chosen spot-there's one alongside that big boulder, up near the head of the pool; there'll surely be a big one in there for they always usurp the best places so as to get the first of everything coming down from the ripples above. Now your fly is hovering right over him. You let it fall and it hits the side of the rock and tumbles onto the swift, dark water. Instantly there is a flash in the depths and a pink mouth rushes at the fly. Now is the time to strike-you can't take it away from him if you try-and a second later will be too late. You strike and at the same time he jumps and hooks himself hard. Now, watch out! There's a lot of alder roots hanging down into the water from that east bank and he darts over there to hide and snag your leader. Look out!-keep him off-give him the butt! Glory be, he's coming down the pool! Did you ever see such chain lightning darting about in a clear sheet of water in your life! Now he's gone to sulk under the big rock; we'll have to get him out of there and work him down into the shallows. Chuck in a pebble-that's the stuff! now 


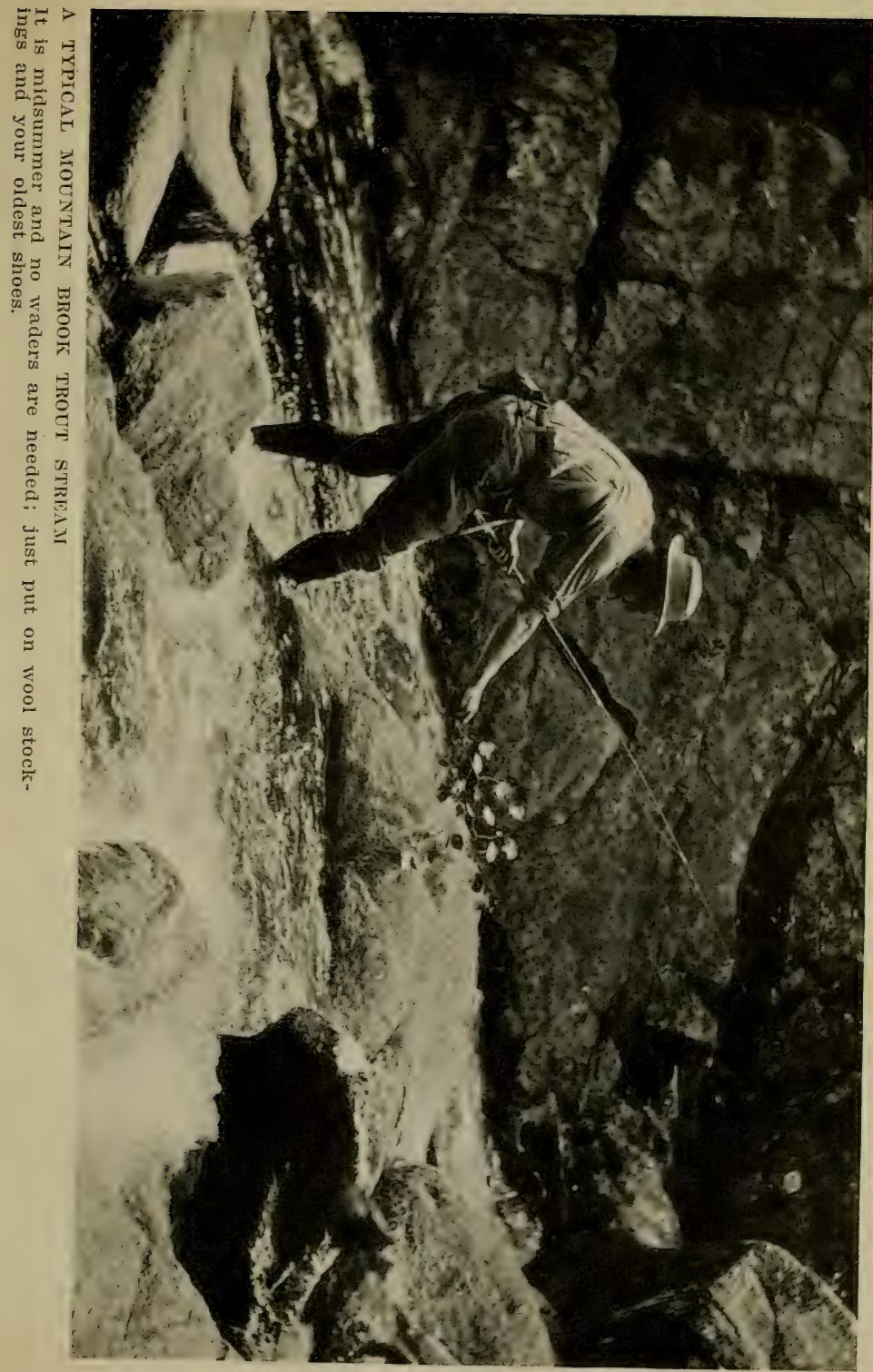



we've got him all over the pool again. Keep cool and strip in your line, holding it against the rod butt with your left forefinger as you go. Now work him into the shallows; now the net-head first-good! we've got him and did you ever see such a pretty trout in your life! He'll go thirteen inches and he's as cold and firm as solid muscle can make him.

Worth catching, eh! Some better than going over to Taylor's Pond after bullheads! Let's work upstream, casting every ripple and keeping a long eye out ahead for the next pool, for a new set of tactics will probably be wanted there.

- Such is trout fishing, another fine art; for fly casting is not to be learned in a day; and also with that same rod and larger flies you can fish the big streams and small rivers in the Eastern and Central States for small mouth black bass who love swift, deep, rocky rivers and rise to the fly as spectacularly as any trout. Boys, it's worth while learning those two games; bait casting and fly casting, and as far as it can be told you on paper we are going to have a try at it. The rest is with you-given a good rod and reel, I'll bet that you'll fly at the practising part of it with all the zeal that you ever gave to any game-and then for the big game fish! 


\section{CHAPTER II}

THE TACKLE TO GET AND HOW. TO USE IT-BLACK BASS

THene are two ways of taking the fighting black bass, viz. by bait-casting for him with the short rod and highspeed reel and by fly-casting with the standard fly rod, perhaps a trifle heavier than the usual thing for trout. Of the two, bait-casting is undoubtedly the more spectacular, harder to learn, and harder to land your fish when hooked. In principle bait-casting reverts to that old game that all country boys play of hurling an apple from the end of a pointed stick. You jab the stick through your apple, take aim at the opposing boy and soak him with it, and the speed and accuracy with which that apple goes far exceeds anything that can be done with hand throwing. Many is the battle royal that we boys had in the old orchard using the sling stick, and many the hard sting from the bullet-like little green apples ! In the bait-casting outfit you have a short rod 5 feet 6 inches long, a highspeed multiplying reel, a fine braided silk line of about 12 pounds break- 
ing strength, and a lure which may be a live frog, a pork minnow and spinner, or one of the numerous artificial lures. With this outfit you can cast that lure up to about 125 feet, and cast it with the greatest accuracy at the usual fishing distances of about 40 feet. An expert can pick up any one of a dozen floating objects at will with the hooks on his lure.

Black bass lie in wait for their prey under the lily pads along their outer edges, under the roots of old stumps, under floats and docks, and in lairs under overhanging bushes; and woe betide any luckless minnow or frog which ventures out across their lurking places. There is a splash and a whirl and froggie or minnow is grabbed and bolted whole before he hardly realises what has happened to him. The game is to work your boat slowly along about 50 feet outside the lily pads and cast every likely spot where a bass is apt to lie in wait. If artfully done, your lure so resembles a minnow or frog making a voyage of discovery that the bass at once strikes and is completely deceived, to his own undoing. Further than this, the bass is so pugnacious that he is apt to take a crack at almost anything struggling in the water or ploughing along on the surface; he honestly believes that he is the boss of that whole lake and he will pounce 
on anything that appears to be making hostile demonstrations. It is this quality that lies at the success of many artificial top water lures looking unlike anything under the sun or the waters beneath. So long as they struggle or throw up a splash they look good to Mr. Bass and he comes at them like a whirlwind.

Getting back to the tackle, the rod used is best made of split bamboo and may cost anywhere from one to ten dollars. It is short and stiff, not too whippy nor too long, about your own height is good, and for ordinary fishing for bass, pickerel and pike - up to about four pounds - the dollar rod will answer very well. Such a rod will be twopiece for convenience in carrying and will have three guides of nickled steel, two on the tip and one on the butt piece. The reel seat is ahead of the grip, not behind it as in trout fishing. The bamboo used in these rods is machine fitted and of fair quality, amply good enough for so short a rod to withstand any strains put on it in fishing. For about three dollars a better mounted rod can be had with agate tip, which prolongs the life of the line considerably since it is the friction of the constant casting of the line through the tip guide which wears both it and the line out. However, for a boy beginning to learn bait-casting I would 


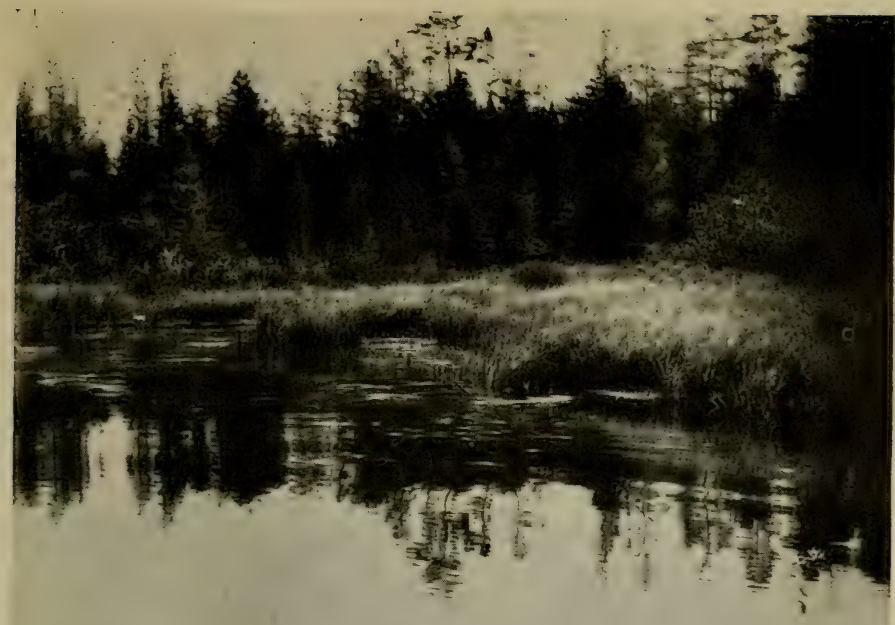

\section{BULLY GOOD BASS WA I'LR}

All these coves along shore deserve a cast from your lure. You float along in the canoe, about the distance from shore of the foreground of this picture, and land your lure accurately in these coves, reeling back immediately your lure touches the water. You may get a strike, any time, up to three feet from the boat.

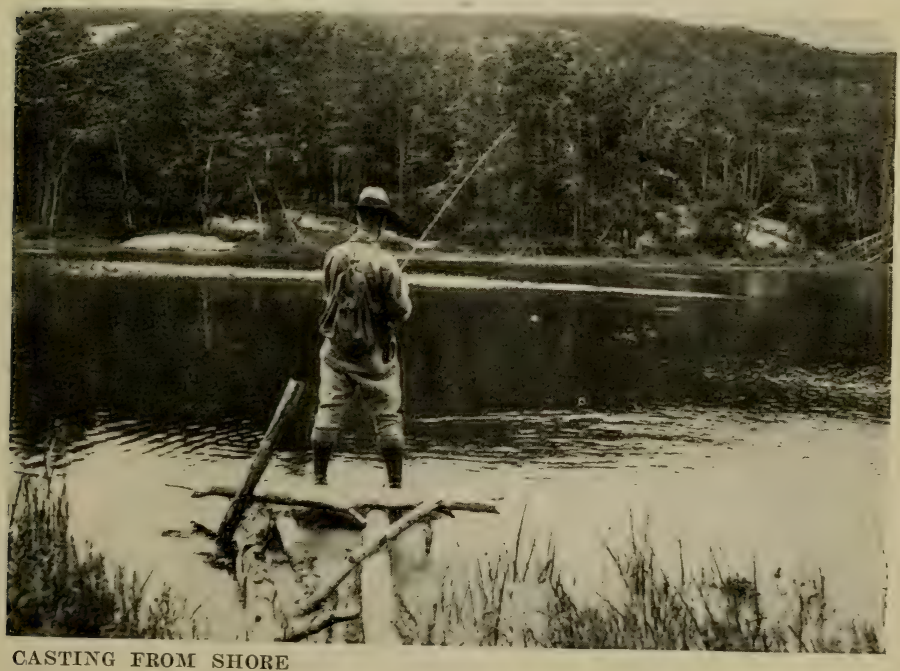

If you have no boat, cast from shore. This boy is using a revolving now and is liable to get a strike any time from where the lure is 



\section{TACKLE FOR BLACK BASS}

not advise a rod costing more than a dollar, at least for the first year or so.

The reel is the most important article in the outfit. Thousands of times during the day's fishing that reel spins at high speed, each time fifteen or twenty yards of line are cast off it and its gears and journals need to be well made and kept well oiled. Then a big four-pounder gets hold of your lure and yanks unmercifully on the reel and will strip every gear in it if poorly made. About the cheapest bait-casting reel that can be relied upon costs $\$ 2$ in brass, nickle plated. It should be quadruple multiplying, capable of spinning free at least sixteen seconds on one spin, rather wide in proportion to its diameter, and should hold 80 to 100 yards of No. 5 line. It should be easily taken apart and should be cleaned and oiled after every day's fishing. The frame may have stout pins or stanchions or else be cut out of a solid cylinder like many of the "Take-apart" reels costing around three dollars. My own boy has used a $\$ 2$ Shakespeare reel for the last two years and it has never yet failed him during week after week of bait-casting for bass and pickerel and I won several tournaments with that same reel before I got a better one.

The line used in bait-casting is of fine braided 


\section{ANGLING FOR BOYS}

silk, the finer the better; avoid coarse thick lines as they are very hard to cast and all accuracy disappears as soon as any distance is introduced. As the wind is constantly drifting your boat while you are casting, you need accuracy at all sorts of distances and for this the fine light braided silk line is needed. A good all-round selection is the Kingfisher No. 5 of 12 pounds breaking strength costing about $\$ 1$ for a spool of fifty yards, though there are many others nearly as good and cheaper, say 75 cents for 50 yards.

Equipped with rod, reel and line, pick out any artificial lure weighing about an ounce and you are ready to learn the art. In casting only the forearm is used; never swipe with your whole arm unless trying for a distance record. Begin the cast well over your shoulder with the rod pointing backward nearly horizontal. Put most of the impetus of your cast in the beginning of the stroke and stop the rod when it is pointing forward at about 45 degrees or even less. The lure should fly out in a rather flat are and your care will be to thumb the reel spool so as to prevent it over-travelling and causing a backlash. Here is the crux of the matter, getting that knack of delicate thumbing the reel, just enough to keep the spool from over running, not enough to retard 


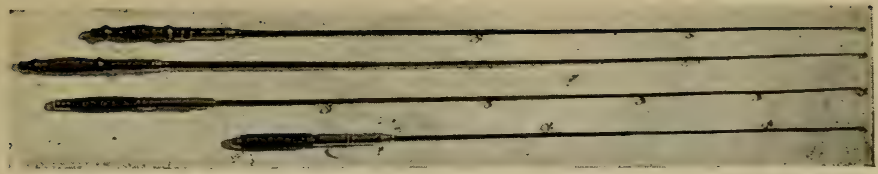

\section{BAIT CASTING RODS}

The top rod is a one-piece split bamboo with agate guides, 5 ozs., $5 \mathrm{ft} .2 \mathrm{in.}$ long, worth about $\$ 5.00$. The second is the famous Field and Stream rod, 5 ozs., 5 ft. 6 in., two-piece, with nickeled steel guides, worth about $\$ 1.50$; has caught a 21 lb. muskallonge. The third rod is all-steel, about $\$ 2.00$; a good boy's rod, as it has no wrappings to come undone. The fourth is a short, $4 \mathrm{ft}$. trolling rod.

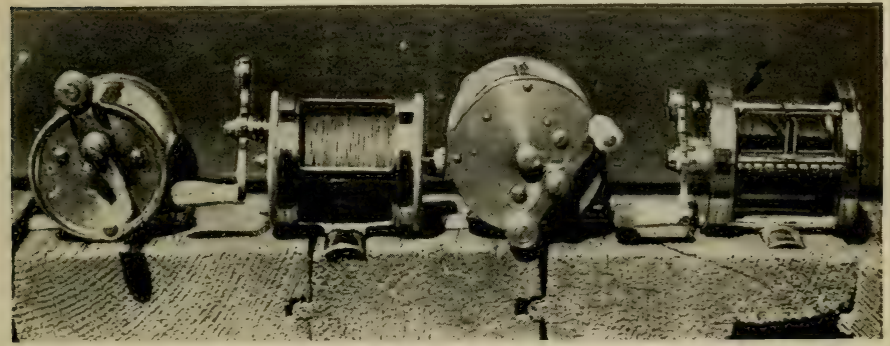

BAIT CASTING REELS

A good one should spin 26 seconds without stopping. The two on the left hand are "takaparts," worth about $\$ 3.00$, and on the right is one with a level winding attachment. A good, plain bait casting reel, good enough for anything but tournament casting, may be had for $\$ 2.00$. The line costs 75 cents for 50 yards, $121 \mathrm{~b}$, braided silk.

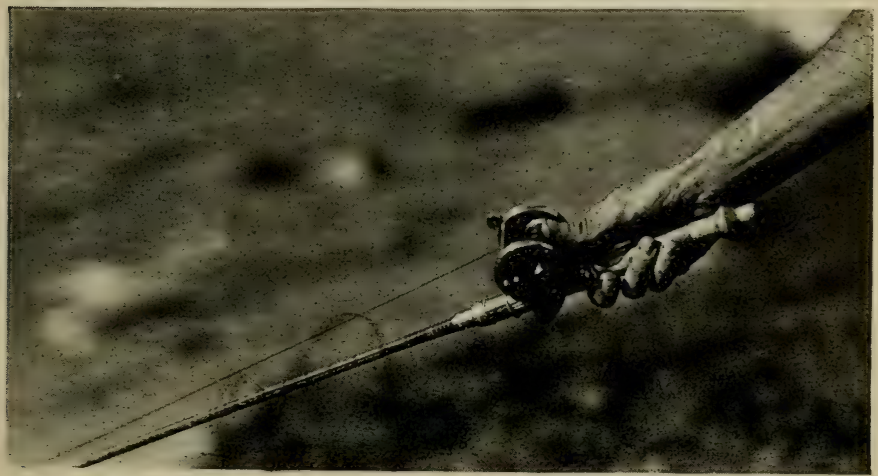

THE PROPER GRIP

Note thumb resting on reel pillar, with tip just touching the surface of the drum; also position of forefinger and third, fourth and fifth fingers in casting. 



\section{TACKLE FOR BLACK BASS}

the flight of the lure. The ball of your thumb rests solidly on one of the reel frame pillars and the tip of your thumb just touches the surface of the line on the spool. As the lure plays out, the thumb follows in on the drum (done by slightly raising your thumb knuckle). When the lure hits the water your thumb instantly stops the reel, the rod is transferred to your left hand and your right begins reeling in. Do not let the lure rest an instant but start it right back or the illusion of a minnow or a frog leaping into the water and swimming away is lost and the bass gets wise to your blandishments. In reeling in, keep the rod tip low and at right angles to the line so as to have maximum room to strike in, for when a bass hits your lure it does not take him a second to find out that it is a fraud and you must strike quick and hard as soon as he does. Once hooked, the whole game is reel play. The rod is so short that it only has about two feet of bend and will not give and take for nine or ten feet the way a fly rod will, so that you must manage your fish from the reel. Some brake the reel by their left forefinger over the rod in front of the reel drum; others use their left thumb resting on the frame pillar. I prefer the latter as it gives all the remaining four fingers to grip the rod. When the bass rushes let him go 


\section{6}

and brake the reel; as soon as he stops grab the reel handle and start him for the boat. Remember that if he gets a foot of slack he will shake his head and flip the lure out of his mouth unless very securely hooked. So keep a tight line on him, take it easy, keep cool, don't yank anything or break tackle and try to tire him out. Work the boat into deep water and get him away from snags, underbrush and lily pad roots, for if he gets you tangled up in them it's all off! Learning accuracy, and getting over the dub period of having a backlash at nearly every cast is slow, uphill work, but the practice is great fun for there is a fascination about bait-casting exactly like in rifle, revolver and shot-gun practice. It is shooting at a mark, with no expenditure for ammunition, for you wind up your missile every time and shoot it again. But, by being careful not to get too strong with your cast, putting most of your impulse into the beginning of the cast, careful thumbing of the reel spool, and careful spooling of the line when you reel it in, you will make good progress. My own boy got to be a fairly good caster in about a week's practice. By "spooling" the line is meant spreading it evenly on the reel spool, for, if allowed to bunch up anywhere, it will run out from under your thumb faster than the thumb 


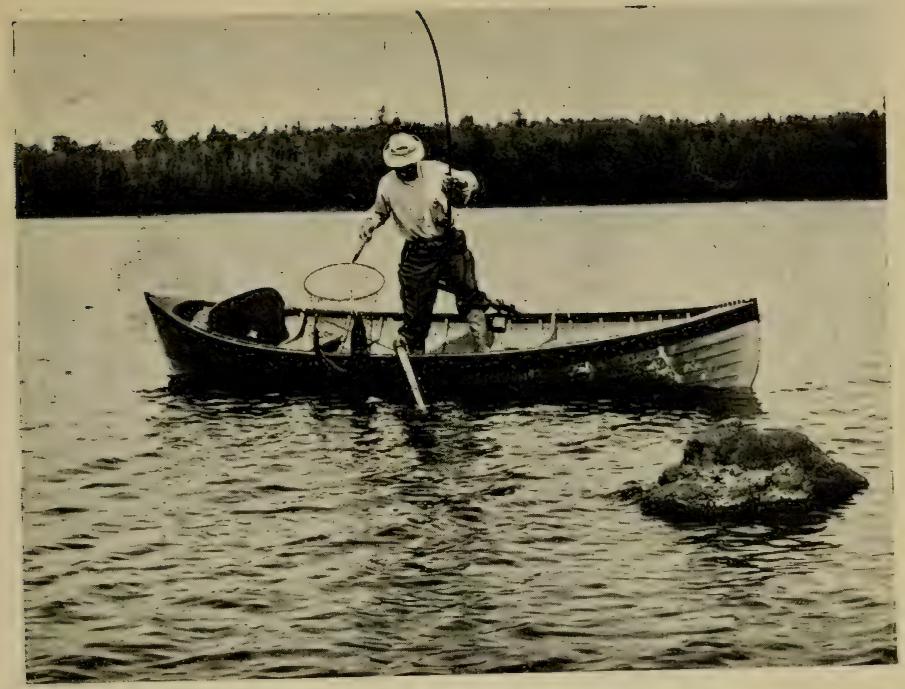

LANDING A PIKE ON THE FLY ROD

Note typical fishing skiff of the western lake region and large landing net - Don't get one too small if you want to avoid losing big fish at the last moment.

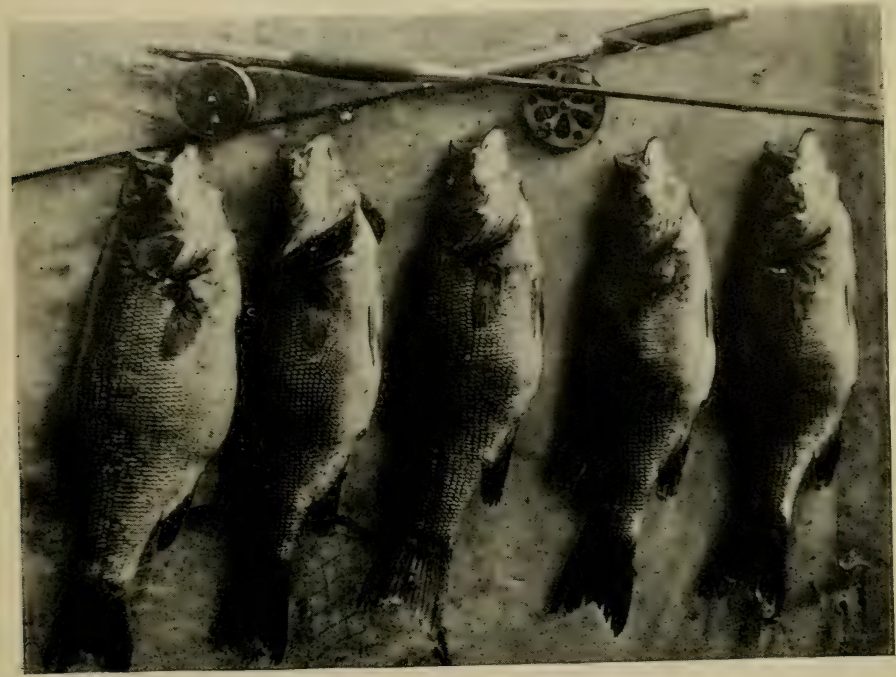

FLY FISHING FOR BASS

Note larger reels and heavier rods than are used for trout; about $6 \mathrm{oz}$. steel or split bamboo is right. 



\section{TACKLE FOR BLACK BASS}

can brake it and you will surely get a backlash.

Spooling is done by your left thumb, over which the line passes, and is laid back and forth over the reel drum by moving your thumb across the rod.

Now, as to lures. For lilypad lakes where the large-mouth black bass flourishes, the most effective are the live frog and the pork chunk or minnow, hung on a red Bing fly with a spinner in front. There is a special large weighted hook with a tie line for strapping the frog down by which he is tied around his waist, leaving his arms and legs free to move. After about twenty casts give your frog a rest, take him off and put him back in the pail, tying on a new one. The bass usually seizes a frog by his hind leg. Stop reeling and let him run off with it. You can feel him turn the frog and gulp him down, and then is the time to strike. I confess to a dislike for using live frogs for bait, and much prefer the pork chunk or minnow. The illustrations show how these lures are made. You have a large red "Bing" fly, weighted, costing about 50 cents. In front of this is a split ring, a brass swivel, a second split ring with a spoon in it, and another swivel ahead of it. In the bend of the hook is the pork chunk or minnow, the latter a four-inch strip 
of pork rind with an inch split at the end to make a forked tail. As this lure is reeled in past the lilypads, the spoon spins around, making a bright flash in the water to attract attention and at the same time making a waving current which wiggles the pork minnow as if alive. It will deceive any bass, and as he always strikes for the red throat of a minnow, he strikes at the red fly and hooks himself. If fishing for pickerel, which always strike at the tail of a minnow, put on a treble hook in the bend of the big red fly hook, letting it dangle alongside the pork minnow, and Mr. Pickerel is pretty sure to hook himself when he strikes at the tail.

For small-mouth bass in rocky waters without lilypads I have generally found the artificial lures good takers. They are easily cast, and are always ready for duty, and the bass seem to strike better at those that have plenty of red on them or at least a red stripe at the throat. Most of these lures are simply cast at likely spots and reeled in, the bass likely striking until within ten feet of the boat, but all the topwaters are fished on a different principle, the idea being to imitate something struggling on the surface of the water and not making any great progress at it either. Whereupon some bass concludes that here is a good meal 
for him-a frog or something or other in difficulties and trying to keep himself afloat.

Still other topwaters have a collar or revolving blades which flash, and to see that thing ploughing insolently along on the surface is more than any pugilistic bass can stand. He'll show you who's boss of this lake!-Biff!-if he doesn't hook himself he will knock that plug at least six feet in the air! For lakes filled with small bass ranging around a pound in weight, the casting lures generally fail; the bass are too small and afraid of the lure. In that case put on a small spinner with a couple of sinkers to make it cast easier and all will be well. Or try them with flies; one or the other will surely get results.

All these lures are useful in their proper place -the pork minnow through and over the lilypads and in the pickerel weed; the red underwaters along rocky banks, overhung with trees and strewn with boulders, which form deep, dark lurking places for piratical bass ; the topwaters in deep water, where one can hardly see bottom, but down there are the big fellows; and the pork chunk for stumpy waters and shallow bays, up in the flags where big large-mouth bass are lying in wait for frogs. It is the judicious selection of these lures and the circumvention of the bass with them; the 
accuracy required to place them right in the proper spot; and the coolness and skill required in handling these big gamey fish when hooked that make the angler's art of bait-casting so fascinating, and I do not know of an outdoor sport more appealing to boys. And, when you combine it with a camp for a week on the shores of a good bass lake-say, fellah, shake! 


\section{CHAPTER III}

THE TACKLE TO GET AND HOW TO USE IT-FLY CASTING FOR TROUT

I PRESUME it is the poets, with their song's about the gossamer lines and fairy wands of the trout angler, that have spread the false impression that a trout line is something fine as a spider's web. At least that is the popular idea, and boys pick up the same notion from what they hear. But let us look at the fundamentals of taking a trout and then build up the proper tackle to fit the case. In the first place you must present him a fly, apparently detached from anything else, and in such a way that the trout has no idea that there is a human connected with it in any way. That means distance from you to him, a line heavy enough to be cast that distance, and an invisible leader at least six feet long connecting the fly to this line. If the line was not heavy it would not shoot through the rod guides and that effectually disposes of any idea of using a thread for a trout line. What you really cast is the line itself, and the leader and fly follow along because they are 
tied to it. To cast a line you must have a long rod so as to put your throwing impulse into considerable weight of line; a short rod will not do because when you have from forty to sixty feet of line out you cannot pick it up off the water at every cast unless your rod is long. Hence we get the standard trout tackle; a light, pliant rod 9 to 10 feet long; a heavy, tapered enamelled line; a light "gossamer" (that's where the gossamer comes in), leader and a fly. With these you can take trout; without them not-unless he is a fool. You will note that the reel is hardly mentioned; it is in reality the least important part of the outfit, all it is for is to hold some 30 yards of trout line and occasionally it comes into play in handling the fish, but most anglers play him on the line alone, "stripping" it in as required and holding it under the left forefinger when taking a fresh hold on the line. The most important part of a trout outfit is, then, the rod. A good one costs money, for it is ten feet long against five for the bait-casting rod and only the best bamboo, well fitted and wrapped every few inches will give a rod stiff enough yet pliant enough to cast the line and play the fish when hooked. However, for a boy, from $\$ 2.50$ to $\$ 5$ will buy a rod plenty good enough to begin with. It should have a cork grip with a 
strong reel seat at the butt of the rod, "snake" guides every foot along the rod, three joints with an extra tip, and silk windings spaced about four inches apart. The material will be of split bamboo, the darker the better. Lancewood and steel have their advocates and the latter has the advantage for boys in that when neglected it will not deteriorate as rapidly as split bamboo, varnish and wrappings are sure to do. Lancewood is apt to lose its strength from dry rot if put away in a damp closet or garret, and, on the whole, the best action in your rod at a moderate expense is gotten with split bamboo. Avoid the swinging ring guides, for the "snake" type are much surer and stronger. Be sure that the reel seat is below, not above, the handle. The latter place is for a baitfishing rod and gives no balance for fly-casting. The line will cost you anywhere from one to seven dollars and its weight should fit the weight of the rod. For boys a 5-ounce rod 9 feet 6 inches or 10 feet long will be about right and it needs a size $\mathrm{E}$ line which can be had of fair quality, not tapered, for a dollar for 30 yards. Leaders are made of fine single gut, knotted into six-foot lengths, with a loop at one end for the line and at the other for the fly. The "mist" colour is the most invisible in clear waters, and you will need two or more lead- 
ers for one is sure to get lost in snag or tree. The reel should be a plain, single, click reel costing: from 50 cents to a dollar and the flies, half a dozen of each, need not be of more than four or five varieties, the best known killers in the part of the country you expect to fish. For all-round flies, the ones that appear to be almost universal in their attractiveness are Parmacheene Belle, a white fly with red whisp of a tail; Coachman, a brown fly with white wings; Cow Dung, a brown fuzzy specimen with brown wings; and some highly coloured type, such as Silver Doctor or Montreal.

Having the tackle the next thing is how to use it, and the first lesson is how to cast. All beginners thrash the rod about like a whip and wonder that no matter how much force they put into it the line fails to respond. The reason is that you are not giving the rod a chance. After you get through, the rod, being springy and having a heavy line on it, wants to keep on, so that it may even touch the ground behind you and is then in no position to cast the line.

Let us begin this way; with say, ten feet of the line out on the water in front of you, strip a yard off the reel with your left hand and raise the rod smartly, tip first. That action will not only throw the line upward and backwards but it will take 


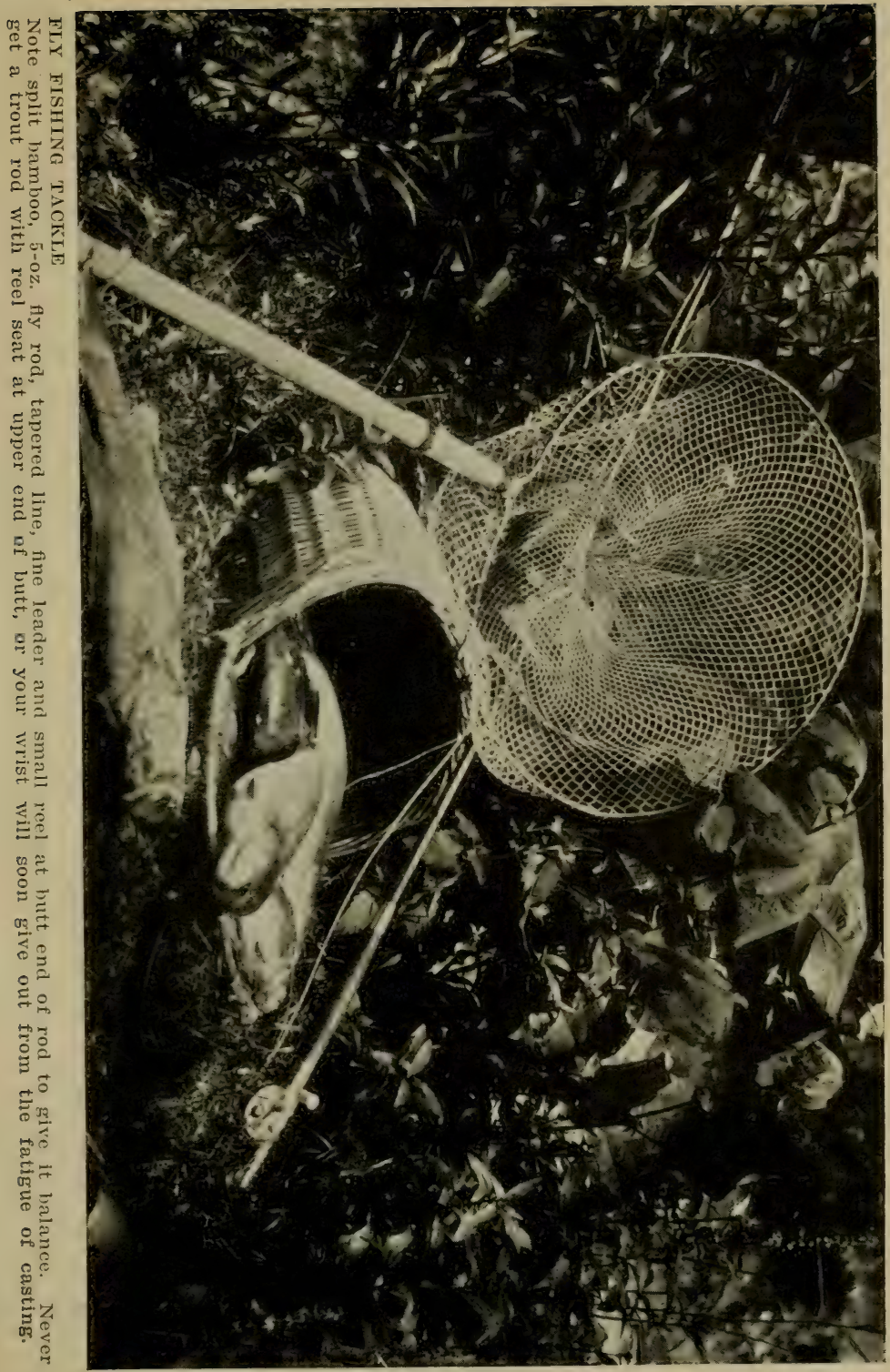



along the yard of line that you stripped. Now when your rod is perpendicular stop your hand (the whole movement is from your elbow to your wrist only). The line keeps on going backwards and bends the rod back with it. Pretty soon the line will straighten out backwards, straight back from your rod tip; it has bent the rod all it can and now the rod of its own accord begins to switch it forward. You can feel that instant distinctly in the action of the rod. Now is your time -you give it an impulse forward with the wrist only, and, as it shoots out forward, you strip a little more line off the reel and this goes out along with the forward cast and the whole thing rolls out straight ahead on the water. At the same time leader and fly straighten out beyond the line and the fly drops like a feather with no visible connection between it and the line. Now suppose a trout were lying there with his head upstream and that fly fell just in front of his nose-wouldn't he take it? Of course he would, unless there was something suspicious about the fly itself. There would be a flash and a pink mouth rushing at the fly and you'd have to strike right off or he would beat you to it and reject the fly before you could possibly set the hook.

Well, anyway, you had ten feet of line out, now 


\section{ANGLING FOR BOYS}

you have sixteen, not counting the leader and fly. Lift the rod and make another cast, stripping line off the reel so that with the next forward impulse you will have 22 feet. There's an art about beginning the cast that you might as well learn right now: Lift the rod high at the butt at the start, the object being to lift the line gently from the water before beginning to snap it backwards. A careless fisherman will whip it right back without trying to lift it off the water, with the result that his line cuts a regular streak across the water and frightens every trout into his hiding place. The fine art is to so lift your line that the fly jumps off it without a drag or a ripple-the chances are a trout will jump after it then and there! Be careful about beginning your forward cast until your back cast is all through; give the line time to straighten out behind, for if you start it back too soon it will be snapped like a whip and the fly will get snapped off in a few such casts. And above all, do not let your rod butt go back of perpendicular; its own springiness alone will take its tip backwards some forty degrees back of perpendicular and if you add to this with your wrist it will go back almost horizontal and have no leverage on the line for the forward cast, in fact you are handicapped almost as much as if you had a short rod. 


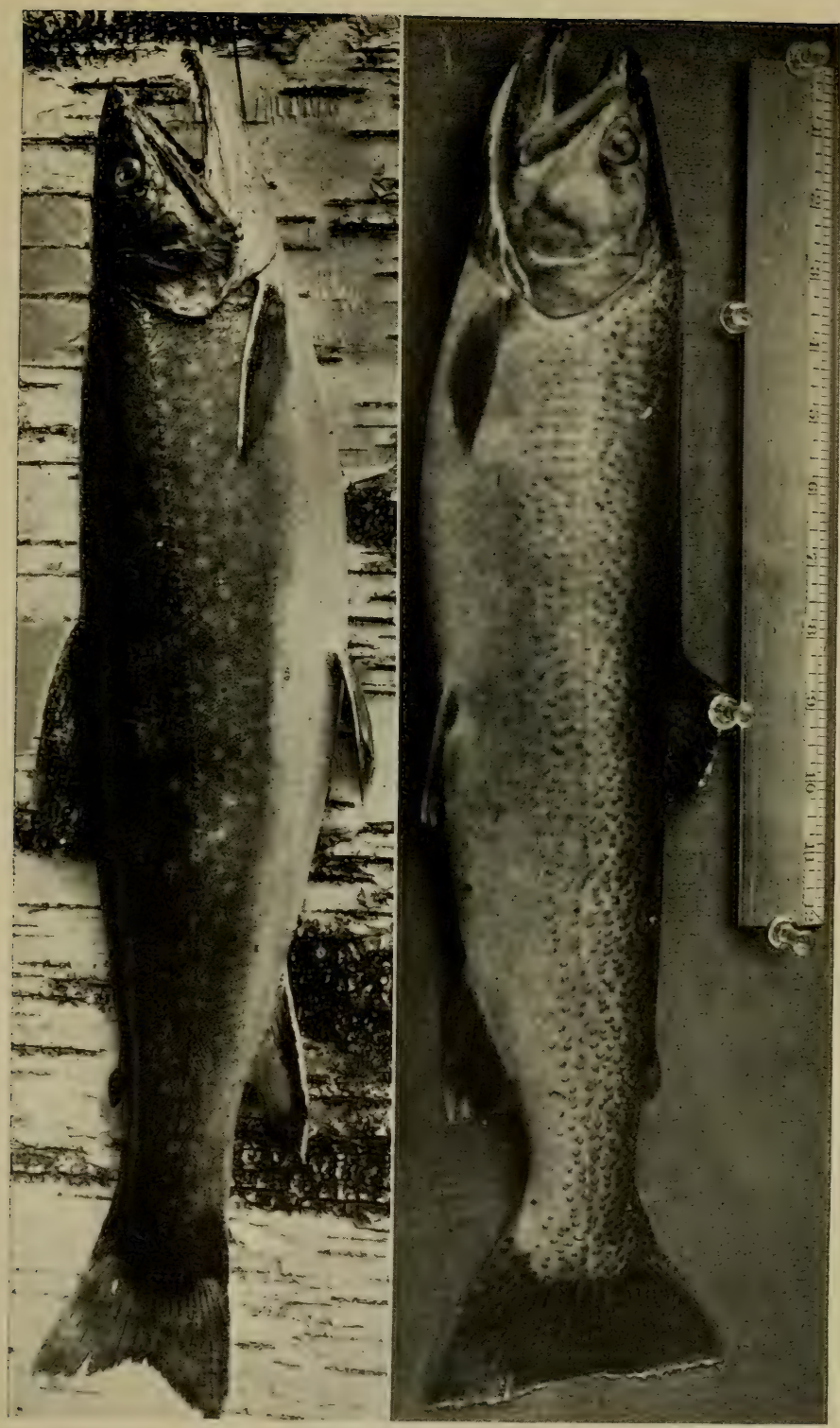

EASTERN AND WESTERN BROOK TROUT

On the left, the heantiful Eastern brook trout; right, the Western cutthroat trout, found in all the Rocky Mountain streams. 

The above describes the ordinary overhead cast. It requires some practice to get the knack of and to perfect oneself in, but not nearly so much as in bait-casting. It can be used in all streams where there is room for a back-cast, and the novice will have no trouble in getting out thirty to forty or even fifty feet of line with it-ample enough for most trout streams and too much for the majority of them.

The next thing to learn is the false cast. Say you have discovered a trout up near the head of a pool, or else good water where there is likely to be one. Now if you go splashing about that pool with your lure you will probably scare him, and if you climb around where he can see you it's all off. The thing to do is to get out lure without allowing your fly to touch the water until it is being cast right over him and then drop it on his nose. To do this we make false casts, that is we begin with, say, twenty feet of line in the air, stripping and casting, recovering each forward cast before the fly touches the water, gradually lengthening our line and working it over to the trout's position until it can be dropped right in front of him. The trick is not to let your rod go much forward of the perpendicular and begin your forward impulse a little earlier. Instead of aiming to cast forward 
over the water, try to cast at a point up in the trees. Your wrist now stops the rod a little back of perpendicular, and you start your back cast the minute the fly stretches out in the air ahead of your line and before it begins to fall. A little practice will get the knack, and still more, casting at a hoop floating in the water, will give you accuracy. Begin at thirty feet (which is easy), increase gradually until you get up to fifty feet, which is about the limit for accurate work.

On the stream you will need rubber boots or waders to really get all the fishing that is possible, for bank fishing is limited, by lack of room for a back cast, to very few possibilities. Much good water will be inaccessible for lack of waders and many fine spots will be hopeless because the bushes back of you are too thick to cast.

A creel or basket is useful, but not necessary, and a landing net is almost essential, as a trout is never more likely to get off than when right at your feet in the shallows and seemingly played out and ready to pick up by hand. 


\section{CHAPTER IV:}

KINKS ON CATCHING GAME FISH

IN our last chapter on fly fishing for trout we outlined what is known among anglers as the "wet fly" method of trout fishing. This is uniformly successful in troubled waters and in wild and little fished streams, where the trout have scarce learnt to regard human beings as deadly enemies and will take any old bunch of tinsel and feathers that looks like a fly. But, like all wild things, trout are a good deal smarter than the uninitiated give them credit for, and soon learn that any one along the banks of the stream, particularly if he waves a rod, is an enemy, and they soon learn that any fly which does not resemble a real insect is apt to have a deadly sting in its tail. The success of all four of the flies given in our last, Parmacheene Belle, Coachman, Cow Dung and Gray Palmer, is because they all closely resemble native insects, the Parmacheene looking very like a small white moth, the Coachman resembling a certain brownwinged beetle, which, with its white under wings, sometimes drops spent on the water, and the other 
two resemble common wood flies and gray moths respectively. In May the Yellow Sally is a particularly effective fly because of the great hatch of May flies which occurs in May and part of June. It is only recently that an American angler and artist, Mr. Louis Rhead; made a systematic study of the native insects of our trout streams, tied flies in imitation of these insects, and reported the results in Field and Stream. But in England the trout have been "educated" for a long time, and it is necessary to do more than get out a cast of flies to take them, so that the English method known as "dry fly" fishing has come into vogue in which not only are all the flies tied in exact imitation of the natural insect but this imitation, the cast being a single fly, not two, is dropped on the surface of the water where it floats with the current, precisely as does the natural insect when spent. If there is no suspicious drag of the leader visible in the water the deception is complete and the trout rises. This method is comparatively new in our country as the flies must be especially tied with bristles and wings cocked to make them float, and not many of our flies are so tied or attempt to imitate any particular insect. However, those that do-and there are quite a few of them that any boy can pick out after spending 


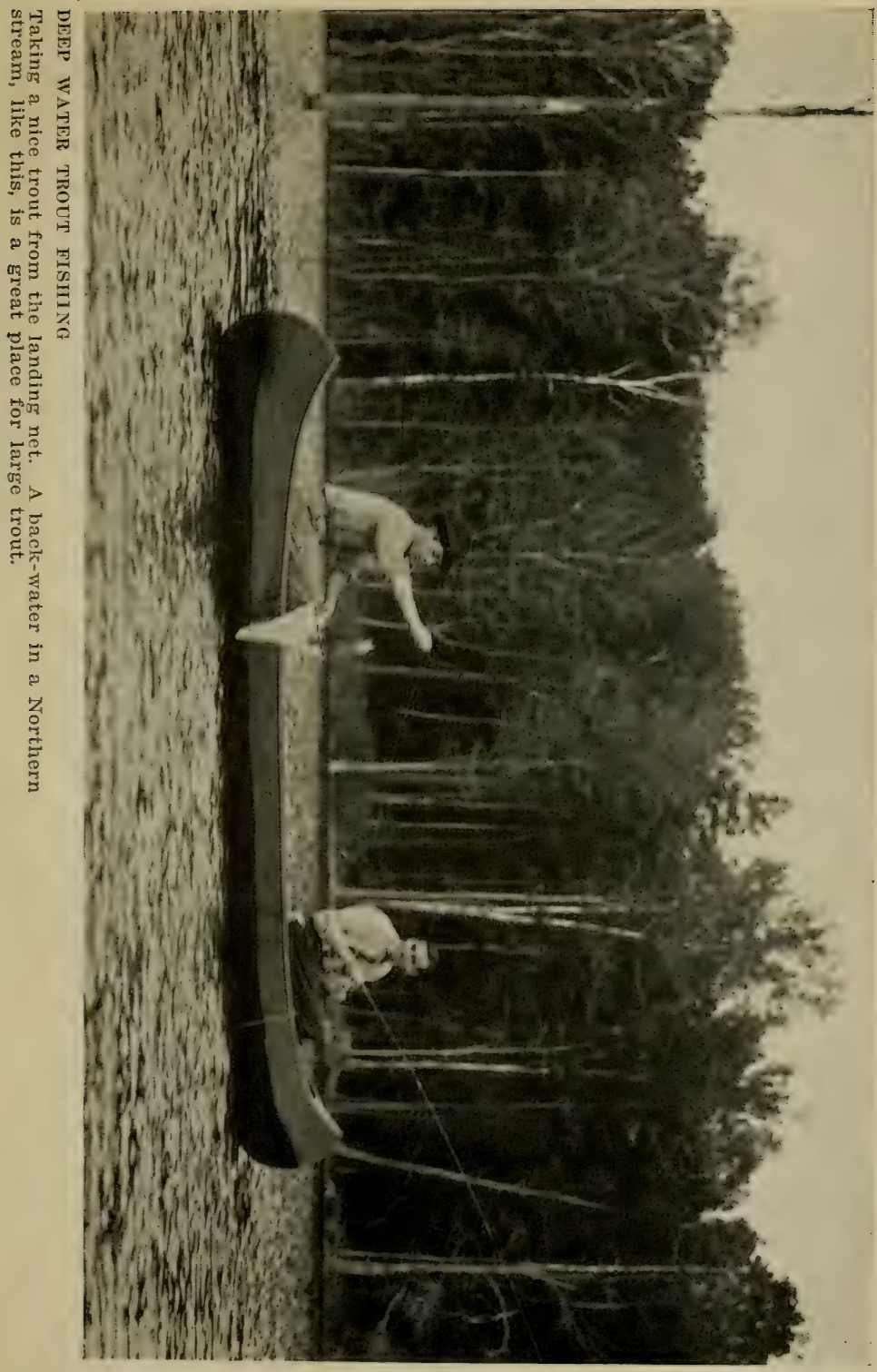



a day studying the insects of his particular trout stream-can be made to float by using "dry fly oil" or paraffine. It comes in a small bottle with a stopper to which a brush is attached. Daub your fly over with this and it will float nicely, even in troubled turbulent water, and will be a great killer, for our trout are wary of wet flies coming downstream under water but easily deceived by one which floats. After a few casts in rough water your paraffined fly will get wet and sink under, but a few false casts dry it enough to make it float again. The oil gradually washes out, so that it needs a new daubing every quarter hour or so, but I have found the dry fly method more taking than wet in most eastern trout streams. In very rough waters, where the natural fly is always sucked under and drowned before he reaches the trout, the wet fly method will always be successful even more so than the dry, but for fishing quiet pools and swift water not too white, the floating fly is the thing-fished upstream or across the stream, of course, and stripped in gradually as it floats towards you.

There are three species of trout which are found in the Eastern and Central States; native brook trout (salvelinus fontinalis); European introduced brown trout, which can thrive in waters warmer 
than the native trout can stand; and rainbow trout, which do not leap but are fine fighters for all that. Further west the cutthroat and bullhead trout swarm in the Rocky Mountain streams, together with steelheads, rainbows and native Salvelinus. These run large and prefer a spinner, or a spoon made of the belly of a whitefish, or else they will take a grasshopper-in any case rising to the fly also, which they want large; Royal Coachman instead of plain, etc. In all these trout, from East to West, the best fishing is got wading up stream because the trout cannot see back himself for 30 degrees on each side of the dorsal fin and he invariably lies head upstream. If you must fish from the bank conceal yourself from view and either drop the fly through the alders or willows and spin it on the surface, or cast from a point out of sight behind the bank. I have seldom fished a stream so wild that neglect of these simple precautions has not resulted in frightening the trout, putting them all down and spoiling the water for several hours.

In fly fishing for bass no such precautions are necessary. The boat is in plain sight as it floats along past likely spots, and the casts are made forty and fifty feet long dropping the fly over likely looking lurking places. The bass does not care a 


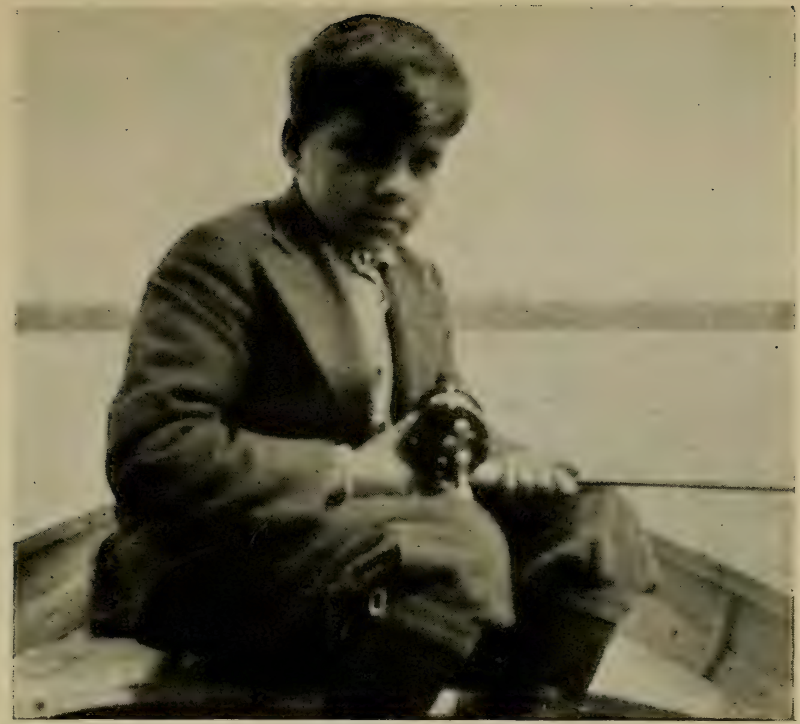

A BOY MUSKALLONGE FISHERMAN

Jack White, 11 years old, who caught a 12-1b. Muskallonge in the Field and Stream National Fishing Contest.

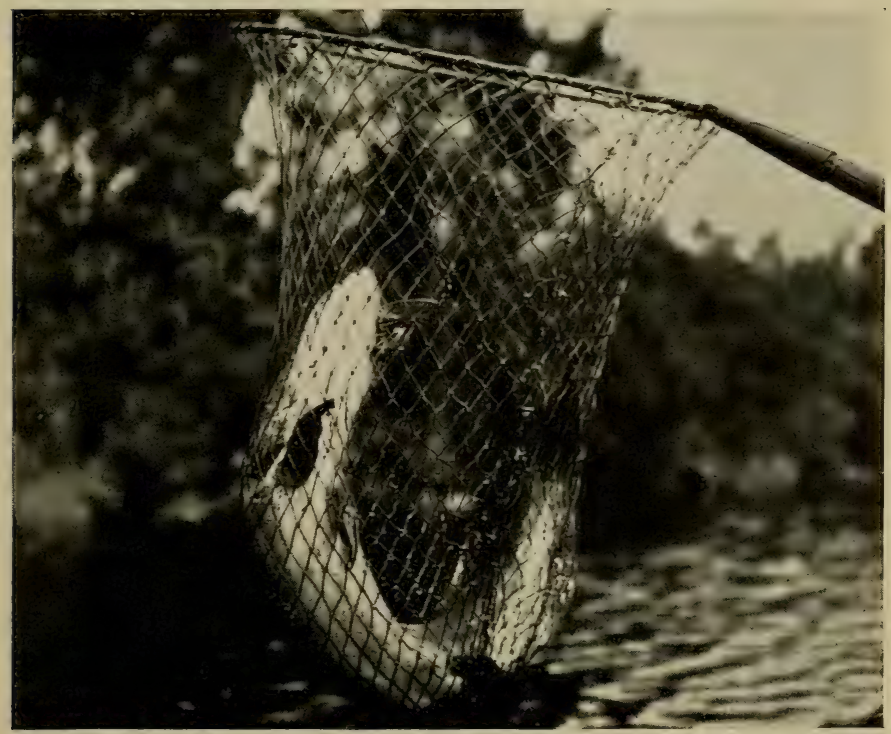

A SIX-POUND PIKE. Note lure in pike's mouth. 

whoop about the boat and has no fear of man or devil. He sees apparently a juicy fly above him and when he starts for it strike quick and hard, for the only place you can sink a hook is in his tongue, the mouth being of bony cartilage studded with many tiny sharp teeth. If he gets an instant to taste that fly he discovers and spits out the fraud faster than you can strike. In playing him the same line-stripping tactics are resorted to as with trout besides handling the boat when he tries to go under it. As the rod follows his every move with the fatality of Nemesis, he is much easier played than with the short bait casting rod and high speed reel. The bass fly rod, however, must be a fine stick of bamboo to withstand his rushes and head him off when he starts for the snags-not less than 5 ounce weight being strong enough. While a ten to fourteen inch trout is an event in the East, bass may run from four to five pounds, and he puts up a much sterner fight because of his weight.

Following the bass come the Esox tribes-pike, pickerel, and muscallonge. The pickerel is not much fun on the bait casting rod because he will turn somersaults out of water and is easily brought to boat, but on a fly rod, taken with a large white fly, he yields an excellent fight. They 
average from one to two pounds and a three or four pounder is quite a fish. With the bait casting rod any minnow, plug, or spoon is effective, provided that it has a treble hook in the tail. All the Esox families pounce on their prey from behind, while the bass strikes at the throat, and that big shovel-shaped jaw of the pickerel is solid bone with a lot of rat teeth studded around it. A single hook will invariably go flat and pull out between his jaws unless he has swallowed your lure, but a treble hook always presents one of the three in catching position while the other two lie flat against upper or lower jaw bone. Pike, especially the Great Northern pike or "pickerel," are much larger than the true pickerel which has never been known to exceed eight pounds. They average four or five pounds weight, and specimens up to 27 pounds are common. Spoons, spinners and the pork rind minnow are the best takers for bait casting along the outer edges of the lilypads, and for deep trolling a large spinner with live minnow is always good.

The muscallonge, the largest of the tribe, is common in the Wisconsin, Minnesota, Northern Michigan and Ontario lakes, and may run up to forty pounds though averaging 12 to 25 . He is taken trolling with spoon and bait casting rod, over beds 


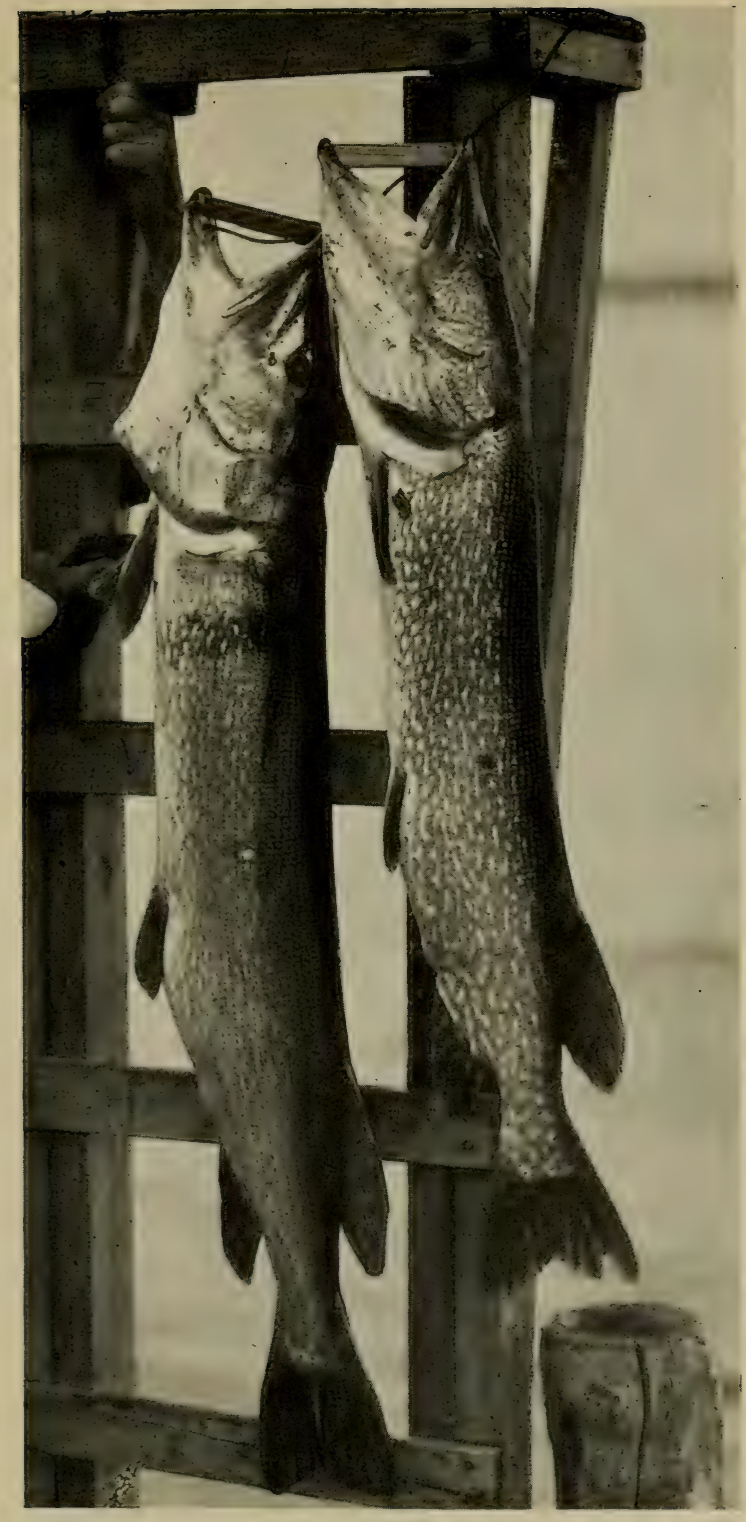

SOME PRIZES FOR THE BAIT-CASTING OUTFIT Great Northern Pike: $27 \frac{1 / 2}{1}$ lbs. and $26 \frac{1 / 4}{1 b s}$. 

where he is known to lie, also bait casting for him with large artificial minnows. Once on he puts up a spectacular fight and takes half an hour or more to land. The line should be braided silk of about 20 pounds breaking strength with a copper leader two feet long, for his teeth are pretty apt to saw through a gut leader or the line itself if attached directly to the plug. Any bait casting rod will answer provided it is reasonably stiff and strong. A 21 pound muscallonge was recently landed on the two-piece split bamboo rod given away as a premium by Field and Stream and costing in the open market not over a dollar.

In general the "star" times to fish are early. morning and from four to seven in the evening when the wind has died down and the sun sets over lake and stream in a blaze of burnished glory. At these two times the fish are about and stirring and will notice anything that looks like food. At midday, in common with all other wild things, they become apathetic and you might as well enjoy yourself about camp and rest up for the evening's fishing. With trout the same conditions hold to a lesser extent, the condition of the water and the rise of insects being more important than the time of day.

There are a thousand kinks and knacks in the 
art of angling which any bright boy will quickly pick up from older anglers; the thing is to get the right outfit and get started. A generation ago boys were loath to travel much in search of sport; if there was no bass or trout fishing near home they did not go at all or contented themselves with sunfish and perch. Nowadays they realise that a dollar or so for carfare to some secluded lake is money well spent particularly if a tent and camping outfit is taken along. Fishing for the game fish is good, exciting sport. I have tried in these articles to sketch out what it is like and to indicate tackle that is good yet inexpensive, well within range for a Christmas or birthday present, and not out of reach of pocket money savings if you go at it gradually. While only the most elementary directions have been given in the small space available what $I$ have written is advice that boys of my acquaintance have used to start in right with. You will soon make angler friends among the men, who are only too glad to help any ambitious boy sportsman along, and who will tell you many more of the finer points of the game than I have had space for. Try it, boys, you who love the woods and streams, and learn what a vast difference there is between "just fishing" and real angling for the fighting breeds of game fishes. 
PART TWO: SHOOTING FOR BOYS 



\section{PART TWO: SHOOTING FOR BOYS CHAPTER I}

FIRST LESSONS WITH THE HAND TRAP

THE Boy in this story, it should be explained beforehand, had been down to Barnegat on a surf fishing and snipe shooting camp in the sand dunes, where for three days he popped away in the blinds with the grown men of the expedition, giving a very good account of himself indeed and turning in thirty-four birds out of forty-seven shells. He used a light $4 \frac{1}{2}$ pound Stevens single-shot 28gauge with automatic ejector, a hard-shooting little weapon, and with his light charges of $5 / 8$ ounce No. 10's did quite as well as we men did with our big twelve-gauge guns and No. 8 shot. Everything from willets to lesser yellowlegs went down before that spiteful little gun, topping off with a marsh hawk shot for a specimen, and all of the Kid's shots were on the wing, too! In all it was a record to make any boy of ten years' age acquire a swelled head. But his stern father did not consider that he had any more than just begun to 
learn the art of wing shooting. The boy showed unusual promise, that was all, but I could see no reason for deviating from that long course of trap and field shooting that teaches one perfect form with the shotgun. And let me tell you that, much as I love fine work with the grooved bore, good rifle shooting eventually leads to the same art as the shotgun-quick, accurate gun pointing. The military shot may take his time and land in the thousand-yard bull'seye after due calculation of windage and miragé, but what the woodsman and the big game sportsman needs is the ability to take a swift and accurate aim at moving objects-say, a flying deer or an elk at a hundred yards-and get him! And this can only be done by the man who has had good form in handling a gun drilled into him from his youth. So the Boy, for all his fine record, started right in at the foot of the ladder, the hand trap at short ranges, set with an easy spring. This trap is shown in our pictures. It costs five dollars and three or four boys who are anxious to become wing shots will do well to club in and get one as it is money well spent, for being a good wing shot is an accomplishment that every gentleman should take pride in and the time to learn it is when you are a boy. With this trap you can throw clay pigeons quite as fast and accur- 


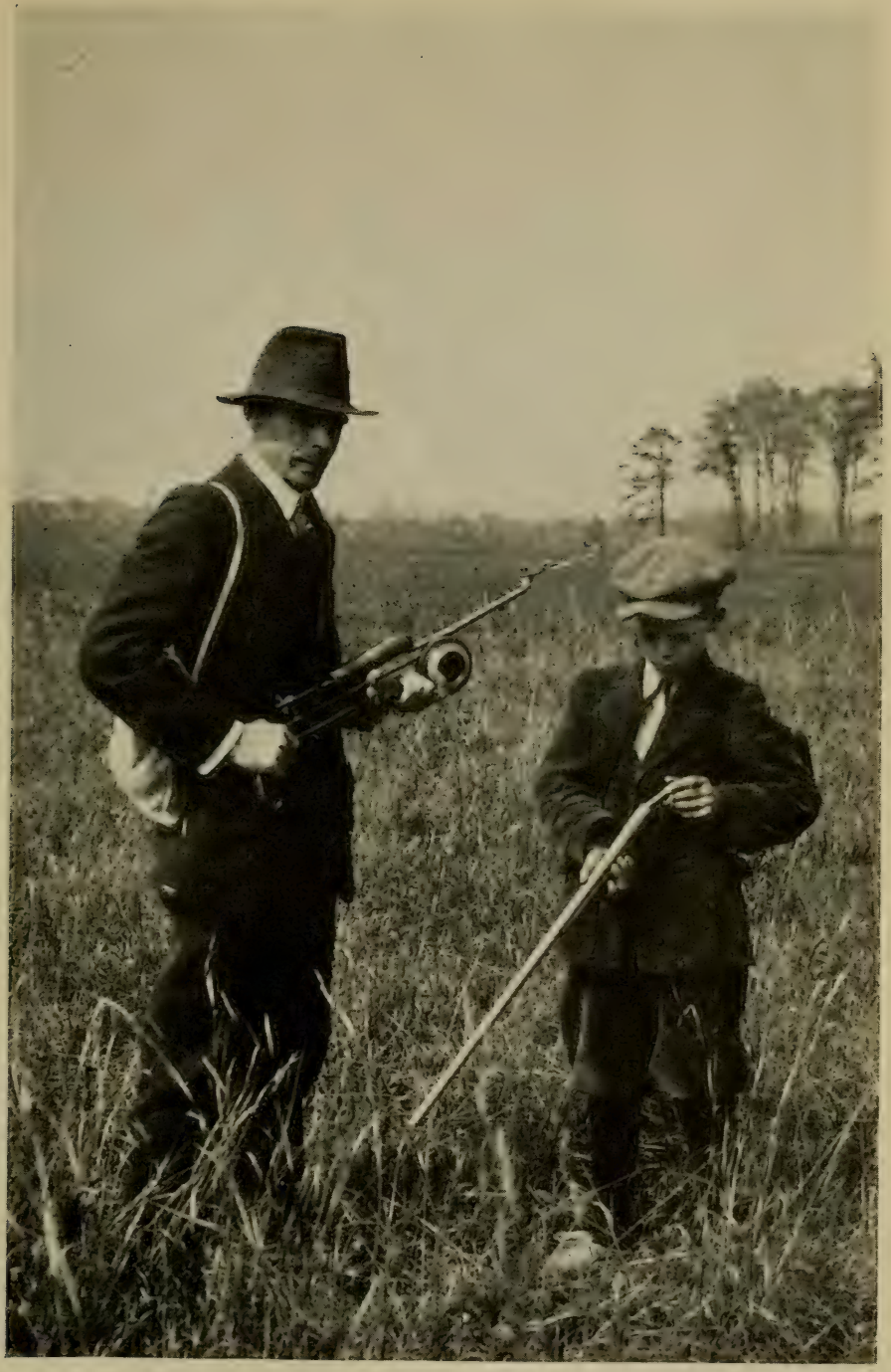

THE HAND TRAP AND SIXGLE-BARRELED SHOT GUN

All the equipment needed to learn wing shooting 

ately as with the standard fixed trap, and it can be carried easily to any specified spot where you have room to practise without danger of hitting any passing wagons or automobiles. It imitates fairly well the flight of the different game birds and is just the thing for all kinds of "surprise fire" stunts. The regulation trap spring, throwing arm, and finger holder have been transplanted to an iron frame shaped like a large horse pistol, weighing six pounds (about the same weight as a boy's shotgun), and it can be loaded and fired by any boy; that is, there is nothing about the handling of it that requires a man's strength. The boy carrying it has a canvas bag slung over his shoulder containing clay pigeons-those little four-inch black-and-yellow saucers which make such a satisfactory target for the shot-gun-and walks along behind the shooter, firing a clay pigeon at unexpected moments and at any angle that suits his fancy.

Of course we did not begin that way. The easiest shot, and the one that every man who goes afield should be the best acquainted with, is the low, straight-away "quail" shot directly ahead, much as the central bird in a covey of quail flies. Indeed it is this shot which is always given the visiting sportsman down South, where our chival- 
rous hosts insist upon your taking the station just behind the pointing dog, since there is always one quail which will fly directly away from the dog thus giving the visitor the surest shot. It was this bird that I started the boy in upon. Kneeling beside him I tilted the trap at a slight angle, told him just where the bird would go, and even allowed him to put his gun to shoulder before springing the trap. Result of our first shot, a clean miss! Hooray for Barnegat! There was a wire fence just twenty yards in front of us, which gave me an accurate guess as to how far away the bird was when he fired. He had shot miles too soon, blazing away before the bird was hardly over the fence. Now, as a clay pigeon, even with the spring set light, will go twenty-five yards in the first second, the kid was trying to hit 'em in less than one second-why, the veteran trap shots take four-fifths seconds for their aim, and here he was trying to equal them! All this I cussed into him -he never had a more forceful teacher-but the next two shots were also misses, all shot at too fast. Then I elevated the trap quite a bit, giving him more skyline as a background and more time to aim, and he smashed the first one. It was not a good smash, just a bird broken in half-probably two pellets hit it-but the Kid was pleased as 


\section{FIRST LESSONS IN SHOOTING}

Punch and he got back a lot of confidence in himself.

"That's the talk!" I encouraged. "Take your time and find 'em before you pull trigger! Remember that these are rising birds, and be sure to cover them with the gun muzzle before you shoot. If you see the bird over the sights, when you pull trigger on rising birds you will surely undershoot and score a miss. Try a shell loaded with No. 10's now." We had both ten and 71/2's chilled, as I was afraid that the spread of shot with a 28 gauge shooting the $71 / 2$ 's would be too great to get many birds, and so brought along a lot of regular quail shells for the 28 , loaded with tens chilled. These tens cannot be depended upon to break a clay pigeon however, as we picked up quite a few later with one and two pellet holes in them that had been scored as "Lost." This time however the range of these high thrown birds was comparatively short and the Boy pulverised the saucer in great shape and began to feel like Barnegat days again. Next we tried a shell loaded with $71 / 2$ 's and he broke that pigeon also.

I now felt that he had got his confidence well in hand and we started in on "quail" again. Kneeling beside the shooter you elevate the trap just enough to get a good sky line and spring it as he 
advances toward the fence. I started with easy straightaways and he smashed them in one-twothree order, shooting with both eyes wide open and always carrying the gun below the elbow, as in actual field work. Let me caution you right here as an old time shooter, never to allow the boy with the trap to go in front of the boy with the gun under any pretext whatever. He must always be behind the other, and this applies also to the temptation to shoot across the line of advance from a concealment in a thicket-never do it unless the boy with the trap is behind a rock or other impervious object. For a gun is always dangerous, and when it is cocked and the shooter looking for a target to spring suddenly before him, no one should be in front of him at any angle whatsoever. This as a rule will give rather short ranges for the hand trap, but the rule should be inexorable. When you want the bird to spring from the ground any distance in front of the shooter use a standard fixed trap, or else a shotproof pit or screen of some sort.

Getting back to our lessons. The Boy got to be a bear on straightaway "quail" right off, so I started them at unknown angles, still keeping them low. We used both tens and 71/2's and there did not seem to be any particular difference, as he got 


\section{FIRST LESSONS IN SHOOTING 65}

most of them just over the fence at about twentyfive yards from the gun muzzle. Taking them at unknown angles he averaged 65 per cent. hits, very fair for the first twenty-five shells.

On the second twenty-five we continued the "quail" shots, sprinkling in a few high fliers, and it was pretty to see him shower these into fragments like a bursting bit of fireworks, for which stunt he got a handclap from a passing automobile. He missed nearly half of these, principally because they were so unexpected that he made his old mistake of firing too soon. It is a good fault, however; far better than pottering over a bird until it is out of range, which is always a sure miss.

There are three other kinds of birds which can be imitated with the hand trap besides the "quail" flying away from you. These are, crossing shots as in pass duck shooting thrown from behind a board sign or big tree, the trap boy being some twenty yards in front of the shooter and not less than eighteen yards to one side of his line of advance; straight head-on shots, thrown from behind a bank on whistle signal, as in incoming ducks; and crossing high fliers, thrown from a rock ledge or high bank, overhead from the shooter's position. All the needful places for such shots can be found anywhere in a walk in the country, and generally 
in places inaccessible to the heavy standard fixed trap. And, to get the latter's capacity to fire pigeons from the ground directly in front of the shooter at sixteen yards' distance, as in trap shooting, all that is needed is some sort of a pit or a rock embankment three feet high, behind which the trap boy squats, firing his clays upon the whistle signal. But before I tell you of our lessons in these steps in the art of wing shooting I must give you some of our tests with a cheaper but efficient hand trap known as the "Ping-pong" trap," in effect a pair of fingers or holder for the clay pigeon bolted on the end of a hickory stick, the clays being thrown by hand, just the way you would sling a potato off a pointed stick. This trap costs but $\$ 1.50$ and in a subsequent chapter we will give some pointers about it and some comparisons with the spring style of hand trap. 


\section{CHAPTER II}

\section{CHOOSING A GUN}

When a boy sets out to buy a shotgun he has two things, nowadays, to bear in mind. The wild game is by no means as abundant now as it was when his father learned how to shoot, and, as the new shotgun game of trapshooting has come into such universal favour, the gun must be adapted to both wing shooting and trapshooting if you are going to get the most sport out of it. Of course if you have lots of money and can own an arsenal, a light brush gun of small gauge, a special trap gun, and a heavy, long-ranger for wildfowl would be your choice, but, as most boys' pocketbooks are limited, it is best to put all your money into one first-class all-around gun; one that will not handicap you at the traps, is not too heavy for brush shooting, and one that shoots a hard and close pattern enough to give a good account of itself in the duck blind. For it is a fact that many a farmer boy has won great trapshooting championships, gotten his limit of ducks every season, and made 
good on quail and grouse, all with a trap-grade twelve-gauge costing around $\$ 30$.

The qualities to be looked for are, first a dense pattern in the left barrel, putting at least 70 per cent. of the pellets in a 30 -inch circle at forty yards, the right somewhat more open, say 60 per cent. for brush work, and second, a straight-stock, from $2 \frac{1}{2}$ to 2 inch drop at the heel and $1 \frac{1}{4}$ to $11 / 2$ at the comb. While it is true that a good trap gun will always do well in the field, the reverse is not true, for many a field gun that does well enough wing shooting will hold the user to a limit of about 18 out of 25 clay birds killed at the traps. The reason is generally that the gun is stocked too crookedly; following rifle stocks, where one has all kinds of time to aim, our makers have a tendency to put out guns with 3 to $31 / 2$ inch dropjust right for a rifle but impossible to shoot well with as a shotgun. We are a nation of riflemen, and we therefore demanded the rifle stock that we were accustomed to, and the gunmakers furnished it as lots of well-meaning but prejudiced sportsmen insisted upon having it. But the English, who get much more bird shooting than we do, have learned better, for they always have a straight stock with no pistol grip (put on primarily because of that big drop) and our trap- 


\section{CHOOSING A GUN}

shooters soon realised that the English were right about this thing, and now the wing shots are following suit all over the country. I have been through the mill on this question personally, and also seen it work out on the other fellows too often to dispute it. I own a beautiful Sauer twelvegauge, as fine a handmade gun as you ever saw, and I got along well enough with it (with the usual quantity of unaccountable misses) on ducks, quail and grouse; but at the traps I hung around 14 to 18 out of 25 and could not better these scores no matter how well I pointed until I bought a Parker with straight stock, drop 21/4 inches. My very first score after that was 13 out of 15 . One of the best shots in our club (the Asbury Park Gun Club) used to do no better than 8 to 12 out of 25 with his good old field piece until he had it straightened to 2 inch drop, and since then he has been in the twenty-or-better squad.

In the field I have bagged six quail out of eight shots with this gun, and the same experience has been duplicated by every wing shot who has tried it. Of course there's a reason behind all this. With a straight stock your cheek becomes automatically the rear sight, and you see broad and clear, well above the gun barrel so that you just naturally point the gun instead of aiming it. 
With the crooked stock of 3 inch drop, the tendency to shut one eye and aim it like a rifle is irresistible, in fact it is hard to hit anything unless you do sight the gun. Not only is time lost and too much rigidity and pokiness thus acquired as a bad habit, but when you cheek the gun, it never comes twice to your shoulder alike and each time you have to use brain and eye to do a lot of adjusting. With the straight stock you have only to point the muzzle; the breech is taken care of by your cheek bone, you see the bird plainly over the barrel and can put your mind entirely upon swinging and judging lead and flight.

As to the gun to select, you have two types to choose from-the double gun and the repeater. It takes a good man to work and aim a repeater fast enough to get in more than two good shots, while the third is more or less a gamble. On the whole the double gun nowadays is preferable for allaround work, because you have your two shots quick and the two barrels are bored to give two different patterns, a great advantage over the single barrel which is limited to one pattern. If this is close enough for trap grade work it will be so dense as to blow a bird all to pieces that is too near you, besides making near shots exceedingly difficult because the charge of shot is still so close 
together. A good field and trap double should have its left barrel guaranteed to put 70 per cent. of the pellets of a load inside a thirty-inch circle at 40 yards, and its right barrel should be bored to give 60 per cent. pattern if you are going to use it for brush shooting for grouse, or 65 per cent. if your principal upland shooting will be for quail. With such a gun you use your left exclusively at the traps; give 'em the right for jumping quail or grouse, or ducks hovering over the decoys; and reach out with that tight old left for your second shot at upland birds or ducks passing at long range or digging away from the decoys as fast as their wings can carry them. That "trap" left on my Parker once reached out and grabbed a quail which had gotten by two guns of my Southern entertainers and was dusting off through a little opening between two long-leaf southern pines. He thought he was through for the day but I took a long chance with the full choked left and tumbled him over at 70 paces-which shot they still talk about down North Carolina way!

A good double by Parker, Ithaca, Smith, Lefever, Fox, etc., will stand you from $\$ 25$ to $\$ 37.50$, and, as they are kept in stock of drops from 2 inches to $3 \frac{1}{4}$ inches and stock lengths of $131 / 2$ to $141 / 2$ inches, any bore specified, one can pretty 
nearly order a gun by mail. I would however go to considerable trouble and expense to get to some large city where a number of guns are kept in stock so as to try them out personally, for if a gun does not fit you exactly it's all off as far as crack scores are concerned, no matter how hard you practise. First, it should hang well and balance nicely in your hands; second, it should come to shoulder instantaneously and without requiring any adjustment whatever subsequently on your part. Shut your eyes and throw the gun to aim, pointing at some object which you had in mind when you closed your eyes. Now open them; your right eye will be looking directly down the barrel and somewhat over it if the gun fits you. If your eye appears to be more than a quarter inch over the barrel it needs more drop; if you seem to be below the breech or too far down, the stock is too crooked for you, try another with a straighter stock. In the matter of stock length the trap and field guns are irreconcilable. The trap length will be too long for quick work in the field, not less than $141 / 2$ inches, while, for boys, a field length of 14 or even $131 / 2$ is essential unless the heel is to catch in your armpit every time you lay the piece. A good way out of the dilemma is to get the length that just fits you for quick work afield and then 

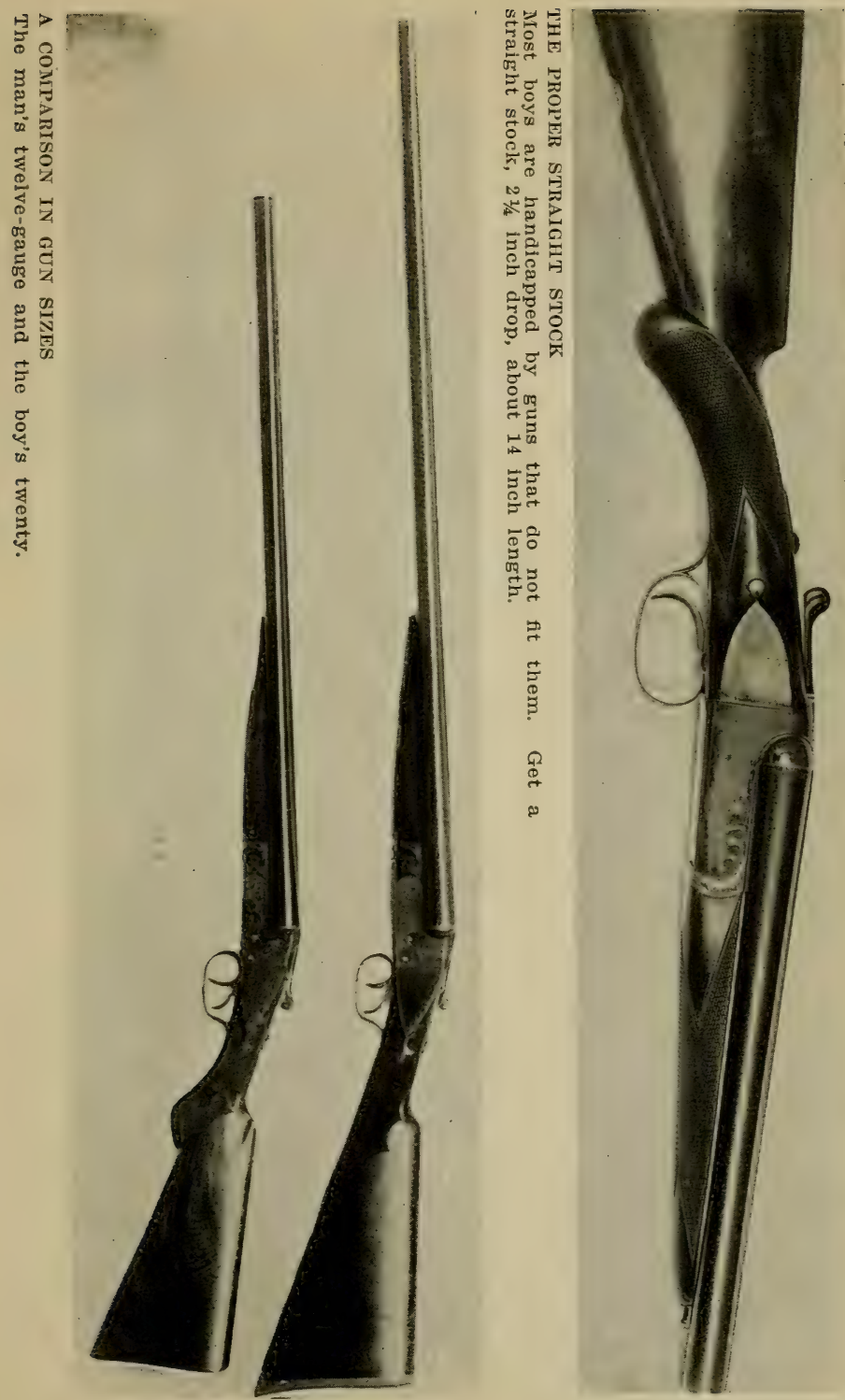

buy a rubber recoil pad, which is to be laced over the butt when trap shooting. Finally, weight; if you are a large youth and will make a sixfooter of a man, you want an eight pound gun. If light built, slender and wiry, 7 to $71 / 2$ will be much better. The same applies to barrel length: A big man will want a 32 inch barrel or else he will get the fault of overswinging. A light-weight could not swing such barrels with either speed or accuracy; for him the 30 or 28 inch, the latter for brush gun work particularly. If you can afford the additional charge for automatic ejectors by all means get them. You will bless the money you spent on them every time the ducks go crazy over your head and circle about like a lot of sheep while the ejectors give you instantly a clear gun into which to shove a new brace of shells.

Among the trap grade repeaters, Winchester, Remington, Marlin and Stevens all put out fine guns, weighing from $71 / 2$ to $81 / 2$ pounds, all guaranteed 70 per cent. pattern, all with matted top rib to avoid barrel reflection. The drop is fixed at about 2 inches at the heel and 11/4 inches at the comb, and the price runs around $\$ 33$ net. One of these guns, the Winchester, won the Grand American Handicap last year, shooting against hundreds of fine $\$ 200$ Daily and Westly-Richards special 


\section{SHOOTING FOR BOYS}

trap guns. In general the Winchesters excel in lightness and all-around trap and field qualities; the Remingtons are noted for their hard hitting, dense patterns; and the Marlin and Stevens for smooth and fast action. Like the double gun, it is impossible to designate any one of them as "the best"; it is entirely a matter of individual preference, and, as all boys are born gun-catalogue students, they know every piece in the action of all these guns by heart and have already made their own individual selection. This article deals with general points which any and all of them must have to meet the requirements of a combined trap and field gun within the range of the boy's pocketbook.

What of the boy who already owns a gun and has not yet gone into the trap shooting game? It may be a cheap Belgian, or one of the good old Remington doubles unfortunately no longer manufactured and now worth their weight in gold; it may be a hand-me-down Piper, Clabrough, Greener or Purdey that father used to shoot; or it most likely will be just a gun, one of those $\$ 7$ singlebarreled boy's guns which were and still are the first choice of the 12-year Christmas. Can these be used for trap shooting? First go out and pattern it. Fire a charge of $7 \frac{1}{2}$ chilled, factory 
loaded shell, at a piece of paper forty yards off, and then count the pellets in a thirty-inch circle drawn around the centre of the pattern, checking off each pellet with a lead pencil as you count it. One and one-eighth ounces of $71 / 2$ chilled contain 387 pellets, how many can you count in your circle? If averaging 70 per cent. for ten shells the pattern will do for trap shooting and you next take the gun to your gunsmith's to be straightened. If he tells you it is hopeless, get a leather cheek pad from any of the big sporting goods stores and build up the comb to around $11 / 2$ inches drop, so that when you cheek it your head will be properly laid over the barrel. Many a fine gun has been so equipped for trap work, its owner not caring to go to the expense and risk of having his fine stock worked over by some ordinary town gun and locksmith. These men usually spoil everything they touch in fine guns, but there are men in the big cities, like Dannefelser of New York, Wundhammer of Los Angeles, and Adolph of Genoa, N. Y., who can do fine work on fine guns and be entrusted with the most precious family heirloom in the gun line.

Most of these cheap guns will be found to shoot too open for trap work, but will answer for practice and learning the game of swinging and point- 
ing after having been adjusted to fit by adding recoil and cheek pads. After you have gone far enough to be convinced that there is the making of a trap shark in you, it is time to pull father's leg for the price of a fine gun such as I have outlined above. I know one youth who won back the entire price of his gun at the very first big shoot he went into. 


\section{CHAPTER III \\ THE "PING-PONG" TRAP}

As told in our first chapter, the Boy's first lessons were with the hand spring trap, and when he got so that he could do about 65 per cent. hits at all angles, the thrower standing beside him and releasing the trap without warning, I decided to try out the "ping-pong" trap, so called. This is a light affair, costing but $\$ 1.50$, weighing but nine ounces and consisting of a wooden hickory handle eighteen inches long with the standard trap throwing fingers bolted on the end of it, making it 24 inches over all. It will thus pack readily in a standard brown canvas camp duffle bag, so I stowed one in our baggage, together with 20 blue rock clay pigeons, when I took the boys down to Barnegat for a camp over the Fourth.

We made camp in a grove of pines the day before the Fourth, five boys and two grown men, and after the crowd had turned out early next morning and fired off all their crackers and used up all the powder brought for a small brass cannon, we got down to the serious business of the morning of the 
Fourth, which was trap shooting for the youngsters and revolver practice for the grown-ups. They all had a swim while we were looking over the ground (every boy had been in his bathing suit from the moment we hit the beach) and now they came shivering after us with their coat pockets full of shells and the precious 28-gauge ready for service. The first question was what could they do with the ping-pong trap? Could boys of from ten to thirteen make it go with any speed and accuracy? And the answer was that they could-some of them-as soon as they got the hang of it. One left-handed boy nearly blew himself up trying to throw a pigeon while everybody scattered and dug out for the bushes to get out of his possible zone of fire. Then he noticed that the trap will only work right-handed, that is the movable release finger works only to the left so that it must be thrown right-handed. We had several .300 batters in the gang but they could do nothing with the trap until they realised that you do not swing it like a baseball bat-you simply have that same sling to your arm that you would use in wielding a whip to get the finger to release properly.

The Littlest Boy, who was but a shorty, couldn't throw a pigeon a little bit because he thought he was a golfer, and the golf swing is "nix" with the 
ping-pong trap. We were throwing the pigeons across a sandy point where they could easily be retrieved whole after dropping, so we soon had two or three throwers in practice and getting accurate enough for the gun. The Boy stepped out with a shell in the 28 and I led off with the first pigeon-result a clean miss! it was miles out of range before he found it and fired. Then one of the boys threw for him, with the same result. We then found that they were going much too fast, and the remedy was not to try to throw them easy, for then they would not leave the trap at all, but to loosen up the tension on the movable throwing finger by the small nut for that purpose. You see, this movable finger grips on the pigeon and holds it by a spiral spring on a small steel rod which connects with the fixed finger. By tightening or loosening this spring, the trap will release the pigeon on a hard throw or an easy one depending solely upon the tension of the spring. So we set it loose and made an easy toss. The pigeon wabbled out slowly and The Boy nabbed it before it got twenty yards. Too easy! Tighten up the spring, my lads! Pretty soon we had the spring. just about right and began to experiment with angles. He could smash anything that went away from him at almost any angle; but I finally got his 
goat by stationing him behind a bush, while another boy threw the pigeon across him and he had to get it before it got out of sight behind a small pine which grew just beyond. He missed these regularly-I'll admit that it was a mighty hard shot-but just as soon as we began throwing them at him at a slant, Bang! Smash! he got time enough to pick them up over the sights.

I believe that he was not leading those crossing birds enough, for I have had them thrown to me from a regular trap house, and believe me, those incoming and crossing birds are some hard! In the first place they are right on top of you before you find them with the gun muzzle, and then they are so close as to be very hard to hit because the pattern of shot has not had any time to spread. As they get closer every minute until they almost land on your head, I found, after missing a lot of them that the trick required was a fast swing holding about four feet ahead of the bird with the gun muzzle going like the mischief. Every hit would then blow the clays to fine dust, showing how close the pattern was. Five straight was the best run I ever made with them.

As we had but twenty blue rocks, and, one after another, these got smashed or broken from falling we did not get enough of the crossing birds by The 
Boy to let him find the proper lead and I am convinced that at that stage of the game such shooting was too advanced for him.

Summing up for the ping-pong trap; as a light, cheap and easily carried pigeon-throwing tool it is all well enough, and if one cannot afford the hand spring trap, by all means invest in one of these. They are by no means as accurate in throwing in any desired direction, and in the hands of a novice are quite as apt to come out of the trap fingers and hit a bystander as to go out ahead where expected. One's general impulse is to duck for cover when some harum-scarum boy gets hold of this trap and proceeds to show the public how to pitch a pigeon -he is quite as likely to soak you as to throw it where he intended. All of which takes the shooter's mind off the real point of the game-to break that saucer with a shotgun. But a little practice will get a fellow so that he can put 'em over the plate with reasonable control, and, by speeding up by tightening the finger spring he can make them hard enough to require a fast gun.

But in general I should arrange the development of a boy wing shot as follows: First, the hand spring trap, then the standard fixed spring trap set at six to sixteen yards in front of the shooter, and finally the ping-pong, walking afield with the 
shooter and springing pigeons on him at unexpected intervals and unknown angles, such as shooting them through a glade in the forest, or an opening in the brush, just as the real bird makes his get-away. Such shooting is too hard for the beginner and it is a waste of pigeons and shells to attempt it before the intermediate steps have been mastered. Really, the next thing after the hand spring trap is to go straight to the standard trap, starting with the twenty-eight-gauge at six yards if the boy is around ten to twelve years.

This was the next step that I took with The Boy in this story, and as I realised that he would soon reach the limit of the twenty-eight and not come back to it until he might some day become a wonder gun pointer I decided to try him out with the 20 gauge. What I mean by the above is that, at a distance of around ten yards, the limit of the twenty-eight for ordinary shooting ability is reached, though a crack shot can take the 28 and stand at sixteen yards from the trap and still get a big per cent. of them. This is because he finds his birds so quickly that they are broken inside of thirty yards from him, while a slow man would not find them inside of forty yards when they would be out of range for the 28. But an ordinarily fast man is not handicapped at sixteen yards with the 


\section{THE "PING-PONG” TRAP}

20-gauge, and a boy will do better with it than with a larger gun because he can swing it quicker. A friend of mine breaks 24 out of 25 with his 20 gauge at the standard sixteen-yard distance and he is no crack with the 12-gauge either. So, for a boy, the 20 is the next logical step.

The Boy in this story is a husky individual for his age of $101 / 2$ years, taller and bigger boned than the boys of 11,12 , and 13 who camped with him. He stands 4 feet $71 / 2$ inches and weighs over 70 pounds, and so, although the 28 would undoubtedly be the best field gun for him, because of the quickness with which he can swing it, the 20 would have to be his gun for standard shooting at the traps.

The two guns compare as follows in weights and dimensions, both single shot, full choked weapons: 28-guage, weight $5 \frac{1}{4}$ pounds, stock length 13 inches, barrel length 26 inches, total 3 feet 4 inches, powder load 2 drams, shot load $5 / 8$ ounces. For the 20 -gauge, weight $53 / 4$ pounds, stock length $131 / 2$ inches, barrel length 30 inches, total length 3 feet 9 inches, powder load $21 / 2$ drams, shot load $7 / 8$ ounces. There you have the whole story. The kick of the larger gun will be about the same as the smaller because its additional weight compensates for the heavier charge, and the 20 will swing 
much slower because of its longer barrel. But, as the gun is already at shoulder in the standard trap shooting holding the long barrel is no handicap, as witness the 32 inch and 36 inch barrels used by professional trapshooters who would simply have to use a 30 inch barrel for a brush gun where speed in pointing is essential.

In our next we will have the story of how The Kid finished with the 28 and graduated into the 20 for standard trap shooting, after which he was ready to take his place in a regular squad. 


\section{CHAPTER IV}

PRACTICE WITH THE STANDARD TRAP

IN two chapters of this series we experimented with the hand spring trap and the ping-pong trap for throwing clay pigeons in taking the first steps in learning the art of wing shooting. Both of these can be made easy enough for the beginner, and yet at the same time too hard for the expert. By that I mean, that if the pigeon is thrown by either of these traps with easy spring and directly from the side of the boy shooting he will find it easy enough to break enough of the fleeting clays to encourage him to practise as long as there are shells to shoot. But if you attempt to go direct from this sort of practice to all sorts of surprise stunts as well as crossing and incoming birds the per cent. of hits at once drops so low as to utterly discourage the beginner. An intermediate step is necessary, something in the line of the standard trapshooting outfit with the trap in front of the shooter. This cannot be had with the hand trap or ping-pong without considerable danger unless 
a pit is dug or a board screen put up in front of the shooter. Of course if you spend your good money on a hand spring trap the thing to do is to put up a board screen or dig your pit, so as to have the advantage of both standard trap practice and field practice with the same trap. It is much quicker than the standard "expert" stationary trap used in the open field, for the latter you have to walk forward to reload every time, whereas a boy seated behind the screen with a pile of bluerocks and a hand spring trap can load it and fire it almost as fast as you can reload your gun, aim, and call "Pull!"

However, as I happened to have a standard stationary trap I put this on a cart and took it out to the field for our first experiments with the twentyeight in standard trap shooting. This trap is secured to a box by its screws and the box has two stout stakes driven into the ground behind it to take the kick of the trap. If you do not provide such a brace the trap will kick backwards and waste most of its energy that way, with the result that the pigeon will make only a feeble flight of a few yards. Having staked it out, I laid out a set of marks beginning at six yards from the trap, then ten yards, thirteen and sixteen yards, our idea being to find just how far back from 
the trap you could get with the twenty-eightgauge, and still hit 'em with any reasonable frequency. The shells used were loaded with 14 grains of dense smokeless powder, equivalent to 2 drams of bulk powder, and the shot load was $5 / 8$ ounces of No. 10's chilled. The Boy took his station at the 6-yard mark, aimed the piece over the trap and called "Pull!"

A straight-away_ "Dead! Nothing to it!" The next shot was an easy right quarter. "Pull!" - "Dead!-Well centred!" The next a straightaway again. "Lost! Shot too high, son." The next a hard right quarter-"Lost!-You didn't lead that fellow enough. Try again." Another in the same spot: "Dead!" Back to a straight-away again for his sixth shot, "Pull!"-_Dead! Say, Kid, you're a shark!'

Now I gave him one of my old discouragers, a mean left quarter. "Pull!"- "Lost!-Shot 'way behind him." We eased up the angle still keeping it left quarter. "Lost!-I guess those left quarters are too hard for you yet." Back to straightaway, "Pull!"-_Lost! We've got your goat now, Kid-brace up!" Another straight-away"Dead!-All to smash-now you're getting mad -soak it to 'em!" Another straight-away, "Dead! What?-again! We can't lose you!" 
Now a right quarter, "Pull!" "Dead! Bustec right in two-Humph, I guess we'll have to move you to the ten yard mark."

The above is no fancy dream but comes right off the score sheet, which is before me as I write. Adding up we get out of twelve shots, seven hits or nearly sixty per cent. which is encouraging enough for the beginner and better than most men do with the twelve-gauge for quite some time after beginning practice at the standard range of sixteen yards, all angles. Analysing, he got five out of seven straight-aways, two out of three right quarters, and missed both left quarters. That tells quite a story in itself, for trap shooting is like baseball and lacrosse and football-not to be learned in a day. I could see at least fifty shells to be expended, one after another, on getting the fast left hand swing required to hit those left quarters with any regularity, and a straight box of shells put in on the right quarters, both at six yards before going any further. And this would only be so much practice; it would tone him up a bit, but real solid improvement, the form that hits 'em every time, would not come until many boxes of shells had been put in on those birds. The straightaways would take care of themselves; they only bother the slow shooter, and The Kid was 


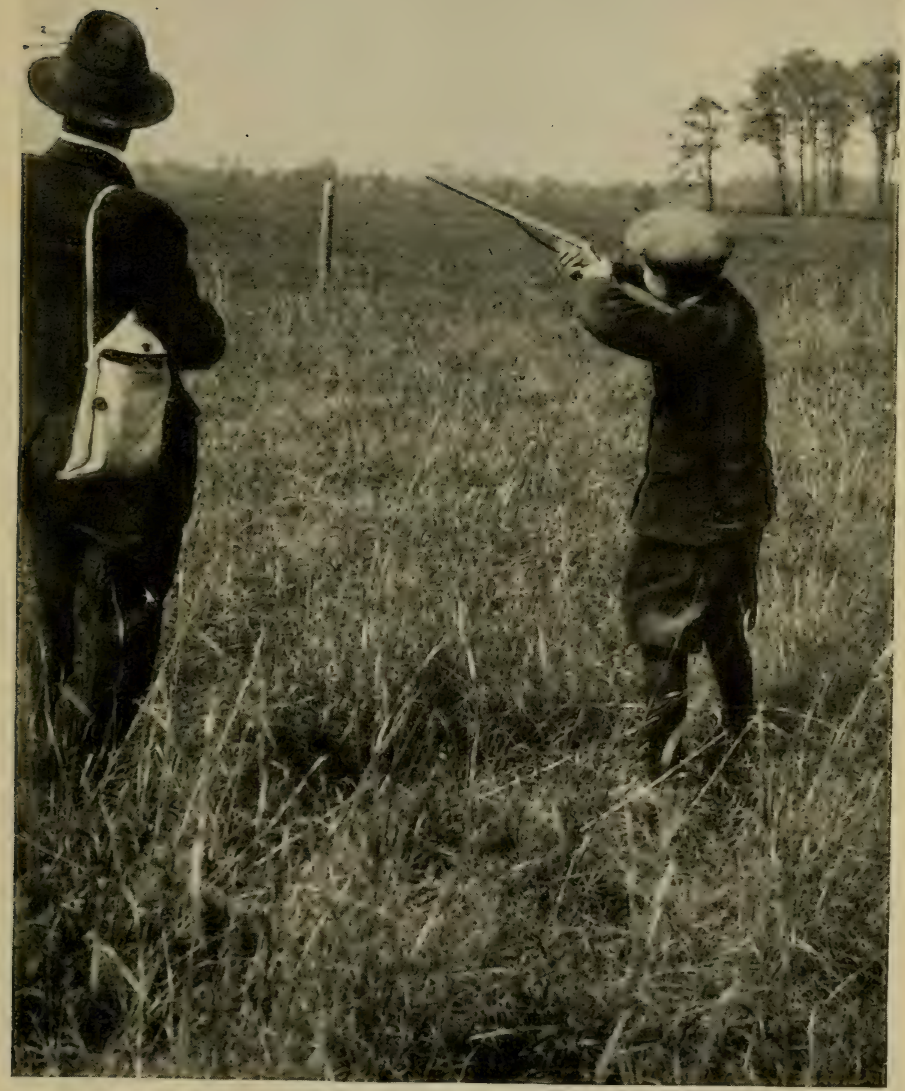

BREAKING THEM Field practice with the ping-pong trap. Note bag for carrying blue
rocks. 

quick-inclined to snap, in fact, and this can only be done with certainty by the veteran crack shot.

But this afternoon's shooting was to be devoted to finding the limit for the 28-gauge, and starting in with the 20 at this limit, so we tried five shells at the ten yard mark: "Ready, Kid?"

"Pull!"-_Dead!-Nice quick shot." Another straightaway; "Lost!"-_Guess you overshot, as you were a bit slow and the bird was dropping when you fired." Another- "Lost! Too quick, over anxious-let's try a right quarter." "Pull!"_- "Dead! Busted to bits!" A quartering bird sometimes has the same effect upon a boy's nervous make-up as doubles have upon a man. It is human nature to act quick and sharp when anything is visibly trying to run away, and if a man gets slow in his time at the traps just give him a few doubles and he will shoot like a fiend in trying to get both of them. In the same way a quartering bird scooting across your field of vision awakens all the shooting nerves into instant action. The next bird was an easy right quarter and he dusted it so we scored it as "Lost," for no visible chip fell out and that is the rule in trap shooting. The bird wabbled as it fell and had a stab from a single ten pellet in it when picked up.

Moving to the thirteen yard mark The Boy be- 
gan to show signs of distress. He got just one out of five birds, and when I tried it myself I missed all three birds thrown to me.

"Gee, Pop, but you're slower than running molasses with that gun!" commented the Kid on the parental misses. I certainly was slower than he, but I was holding accurately enough to have made all three of them kills with the 12-gauge. I think at 13 yards that we reached the limit of the 28 until the Kid with his faster speed could become considerably more accurate and judgmatical in his holding, so we decided to change to the 20gauge, as we were only three yards from the coveted sixteen which would let the boy have the ambition of his life-to go down to the gun club and shoot along side the men at the standard range, using his twenty-gauge.

But the particular gun that we brought along soon showed that it did not fit him at all. The drop of three inches was far too great, the stock length was too much to get the butt well in on his chest, and every shot gave him a jolt on nose or lip. Presently his lip began to bleed and I could see that he was flinching from the punishment and missing them much more than he ought. Now a boy of his size ought to shoot a 20 almost as well as a 28, provided that it fitted him. I had at 
home in the gun cabinet a beauty double 20 , a $\$ 60$ grade Sauer, and it fitted him like a dream, but was otherwise entirely unsuitable, being much too fine a gun for boys' use and being a double gun, much too dangerous for field shooting. But as he would need to go to 20 gauge both for standard trap shooting at 16 yards and for duck shooting in November, where the 28 would be too small, I decided to call off the shooting for the afternoon and take out the beauty twenty for practice, with one barrel only, the next time we went at the traps. 


\section{CHAPTER $V_{\text {s }}$}

\section{THE SWIFT AND SPITEFUL TWENTY GAUGE}

THAт the twenty-gauge shotgun can hold its own in competition with the standard twelve-gauge, the following table of scores will go to prove:

\section{Comparative Table of 12 and 20 Gauge Scores Cosmopolitan Gun Club, Manila, P. I.}

12 GAUGE-50 BIRDS

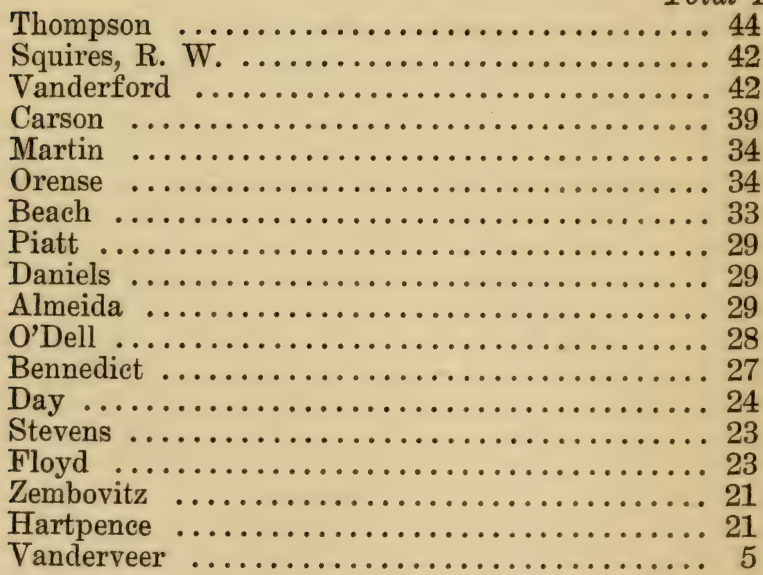

Total Dead

Squires, R. W. ............................ 42

Vanderford .........................42

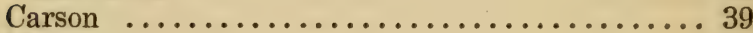

Martin .............................. 34

Orense $\ldots \ldots \ldots \ldots \ldots \ldots \ldots \ldots \ldots \ldots \ldots \ldots \ldots, 34$

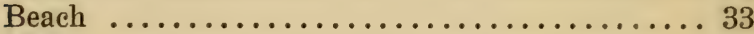

Piatt .............................. 29

Daniels ............................. 29

Almeida ............................ 29

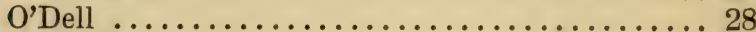

Bennedict .......................... 27

Day ................................ 24

Stevens ............................... 23

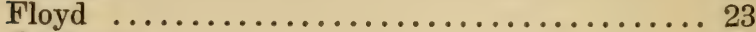

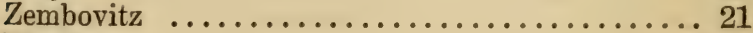

Hartpence ......................... 21

Vanderveer $. . . \ldots \ldots \ldots \ldots \ldots \ldots \ldots \ldots . . .65$

20 GAUGE-50 BirdS

Squires, C. D. ......................... 32

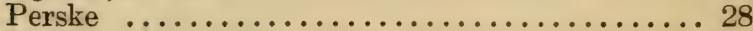

Hodges ........................... 27

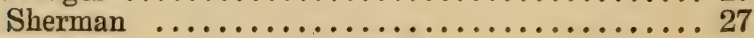




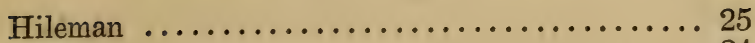

Carter .............................. 24

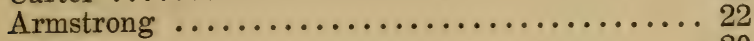

Cisar ............................. 20

These were shot for the Field and Stream trophy cup by the Cosmopolitan gun club of Manila, Philippine Islands. As there is necessarily a difference in per cent. between the two classes, the twelves and twenties were kept separate, but it shows what ordinary fair shots can do with the twenty-gauge. Experts, of course, can do much better, many crack shots with the twelve doing 95 to 97 per cent. with the twenty. As the little gun shoots harder in its effective range, a single pellet from it at thirty-five yards will break a pigeon, while one from a twelve at forty will only "dust" it. And, as the swift and spiteful twenty is an exceedingly fast-handling gun, there is no reason why a boy, with his quick sight and high strung nervous organisation, should not make better scores with it than he could hope to make with the twelve. As an example of being over-gunned, I myself had recently a striking example. With a fast, light twelve I had just made a 21 ; taking for the next squad an excellent but heavy special trap gun to test for a friend I at once dropped to 12 , although a heavy-built expert who took it in the next twenty-five did 20 with it the first time. 
With The Boy, the proposition of joining the Gun Club boiled down to the fact that if he could stand the kick of the twenty he could join the coveted men's squad at the Gun Club. He was already fast with the twenty-eight, but its effective range was limited to thirteen yards from the trap, an impossible distance for it would necessitate his standing three yards in front of the shooting stand. But between ten and thirteen yards from the trap his little 28 would "bust" them with great regularity, and so I now initiated a series of afternoons of practice with the twenty-eight at these ranges, giving him varying angles and a flock of main right and left quarters. Personally I could do nothing at all with the little gun, not having anywhere near speed enough, but the boy got to be as quick as a cat with them, and his snipe work along the Barnegat dunes this year, with his decoys and making his own blinds, was good enough to please the most fastidious. Getting down to figures it averaged one to three birds better than the total number of shells fired, showing what good trap practice will do for one's field form.

This fall there came up stronger than ever the question of graduating to the twenty-gauge. Since these lessons began he had grown seven months older and heavier, and was already sure of himself 


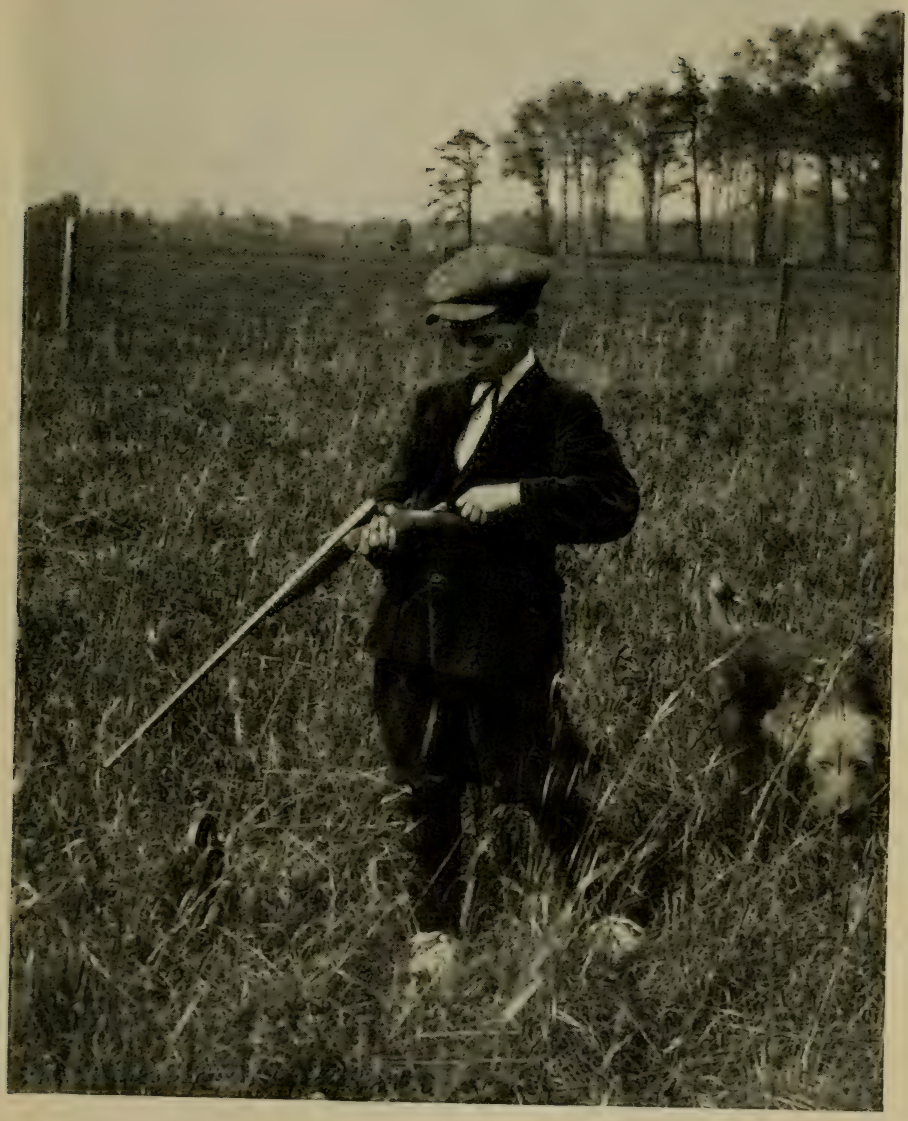

FIRST LESSONS IN WING SHOOTING

The 28 -gauge single-barreled shotgun is just right for a boy from 11
to 13 years old. 

with the twenty-eight. You will recall that the last experiment with the twenty was a few shots with an extremely "crooked" gun, one that had $31 / 4$ inches drop at the butt and a high comb. While the shoulder kick was not appreciably heavier than with the twenty-eight, he was badly punished about the face and his lip began to bleed at the third shot. The shoulder kick, even if it bothered him could easily be remedied by lacing on one of the standard leather and rubber shoulder pads, for sale at any gun store, but there is no cure for a crooked gun. It must fit, not only for comfort but to be able to hit anything with it. Many a boy has struggled along and given himself up as a dub with the shotgun simply because his gun did not fit him in the first place. A drop at the heel of two to $2 \frac{1}{4}$ inches is ample, and at the comb it should be from $1 \frac{1}{4}$ to $13 / 8$ inches, which you can easily test for yourself by putting the gun barrel down on the floor with the butt up and measuring: from heel and comb to the top line of the barrels, which will be the floor line itself.

In order to let him join the gun club, I could do two things: lend him my beauty Sauer 20, a $\$ 60$ high grade gun; or buy him a single shot 20 of the same make as his 28 , with automatic ejector short 26 inch-barrel, 2 inch drop at the heel and 11/2 
at the comb, 131/4 inch length, full choke bored, weight $53 / 4$ pounds. Such a gun would cost $\$ 6$, and he could neglect it a bit without ruining it, while the least scrap of rust anywhere in the works of a high grade gun puts it off its fit and necessitates a trip for it to the gunsmith's. Another thing; my man's-sized twenty, while only $53 / 4$ pounds weight, is stocked for field work for a man's frame, 23/4 inch drop and 141/4 inch length, and it therefore would be hard for him to shoot. However, as the right length is not as essential for trapshooting as it is in field work (because at the traps your gun is already at shoulder when you call "Pull!"), I decided to try him out on a few lessons with my fine twenty before going any further.

We bought a box of shells and started in at ten yards. This time he did much better, partly because of the extra practice with the 28 , and partly because my 20 was a short brush gun with 26 inch barrels and he could swing it quite as fast as his own 28 which has the same length and weight. There was still some face punishment however, due to the big drop as it made him get his face right down behind the breech to aim properly. This I corrected by having him raise his face and compensate by taking the birds a little below, but it was only a makeshift, for your cheek bone is 


\section{THE TWENTY GAUGE}

your real rear sight and the gun should be cheeked tight every time, leaving you nothing to worry about but finding that bird with the front sight.

Soon he got to hitting them around sixty per cent. and I moved him back to the standard sixteen yard distance and began with straightaways and easy right and left quarters. He dropped down at once to thirty per cent., but even that is fair for the standard sixteen yard distance. How many men with a twelve gauge, or boys fifteen and over for that matter, do better than that on the start? The principal difference however was that The Boy did not stay at this per cent. long; all that previous practice with his 28 stood him in good stead now, and as soon as he got the hang of it and began to pick up speed his per cent. rose. Then I began to tighten up the spring on the trap and speed up the birds. I set a goal of fifty per cent. average with the twenty, with a new "Nitro special" of that gauge and an entrance to the Gun Club as reward. It does not take long to tell how we struggled through to that goal, but it actually took a good many afternoons to really do it, for there is a lot to "hitting the clays" and under no two weather conditions do they fly alike. I have seen a whole squad of cracks undershooting all their birds simply because a strong breeze was 
blowing directly towards the traps and the pigeons were soaring instead of dropping in their usual curve. I missed my first five straight on that occasion before I tumbled to the fact that the usual aim, seeing the bird a little over the sights, would not do, and on that particular day you had to cover them as you pulled trigger.

All this The Boy had to pick up day by day while learning to point the twenty and swing it as fast and accurately as he used to his 28. On cold windy days he would get slow, and as we had both a standard fixed trap and a hand trap we got them both to work and he had to be quick with the first bird or lose them both. If he was missing quartering birds it was a sign of a falling off in gun swinging and I would have him go around to one side of the trap until the birds were flying nearly across his face. It is easy to put in these variations to correct especial faults with your own trap: it is impossible to do them at the club stand where the birds are sent away at all angles and there is no chance to hammer away at any particular weak point until it is cured. It is not too much to say that, unless a boy has particular aptitude for wing shooting, he will be a long time getting ahead at the club trap in a regular squad, and 
will spend enough on shells to pay for a trap before he arrives at proficiency. Even to own a cheap ping-pong trap, firing it from a pit or behind a screen is much better than starting in blindly at the standard trap game. I was over a year in correcting a tendency to miss left quartering birds, simply because I had no chance to hammer away at the fault until discovered. You get a left quarter about every fifth bird, sometimes two of them in a row, always more or less unexpected, and as I was strongly right-handed I was always too slow and inaccurate in swinging on them, until I had a chance to correct it by banging away at fifty of them in a string.

All this practice meant considerable cartridge expense, more than any boy's pocketbook can reasonably be expected to take care of. I considered it unfair to let that expense come on The Boy, as the accomplishment of wing shooting lasts a lifetime, like swimming or skating, and ought to be paid for out of the parental exchequer just as are music lessons for the girl of the family. But as a boy's time is not excessively valuable there is one way in which he can help father out on the expense a great deal, and that is by reloading his own shells. Any reasonably steady boy of twelve 
or over can be entrusted with the job, provided that some older person sees that there are no fires, cigarettes or matches in the room where the reloading is being done. The twenty-gauge shell takes 2 drams of bulk smokeless, then a thick wad of soft felt, one thick one being better than two thinner ones of the same total thickness because often the latter capsize in the gun barrel letting the gases get by the wad when their propelling force upon the shot is lost. You can note this often at the traps whenever you see a wad spinning out on its edge and falling a considerable distance away unmutilated. After the powder wad, comes $7 / 8$ of an ounce of No. $71 / 2$ chilled shot, a thin cardboard shot wad, and the shell is crimped in the crimping machine. Cost of reloading about three-quarters of a cent each, whereas loaded shells cost around sixty cents a box of 25 in twenty gauge. Most modern paper shells are good for at least two reloadings. You can tell when a shell is getting too old by the black powder rim that begins to show on the paper above the brass base of the shell. We boys, when we were fourteen and fifteen years old and had graduated to twelvegauge double shotguns, used to get all our shells, powder wads and shot wads for nothing by going around to the gun club grounds after each shoot 
and picking up the discarded cartridges at the stands, looking around in the grass some fifteen yards in front of the stand for powder wads, which were to be had in quantities and in good condition, and a little farther on we found the shot wads. Our only expense for ammunition was then primers, powder and shot. With primers at 35 cents a box of 250 , powder at 65 cents a pound can, and shot at eight cents a pound, we could always find ourselves in ammunition enough for field shooting, though never enough for trap shooting unless it was with the home trap. A reloading set costs about a dollar and should comprise a crimper, capper, decapper and rammer, powder and shot measure and funnel. A reloading bee where two or three fellows get together of an evening after a good day's shoot is always great fun; there is no better way to put in the time, for a bunch of good fellows who love shooting and guns.

By the time The Boy showed a fair fifty per cent. gencral average on those occasions when he took an examination so to speak with the twenty after steady practice with the twenty-eight, I felt bold enough to present him at the gun club and ask the men to let him join a squad next to me. Meanwhile the quail season had come on and there was a good deal of upland and brush shooting for him 


\section{SHOOTING FOR BOYS}

with the twenty-eight. What he learned about the ways of quail and how he got started at regular trap practice at the gun club will be told in our next. 


\section{CHAPTER VI}

THE FIRST DAY AT THE GUN CLUB

Ar last the great day arrived, The Boy's first shoot at the Gun Club! Our club has two Leggett traps, in trap houses set on piles out over the ocean, and the city board walk runs right behind the trap stand so that there is always a large and interested audience when shooting is going on. The Club has two hundred and fifty members, so that if there is much of a turnout both traps are in use, the south trap for experts shooting in runs of 25 birds, the north trap for beginners and practice work, their shoots being usually of ten and fifteen birds. The Kid and I each had a box of twenty-five shells, and he had elected to start in with his favourite old 28-gauge, the gun that gets meat for him every time in shorebird shooting. This year at Barnegat he had turned in more birds than shells, because of several neat doubles made with the single gun.

I have outlined the preliminary practice that he went through before venturing down to the 
Club; it was mostly 28-gauge practice at six, ten and thirteen yards; now he was to start in at sixteen yards from the trap, and those traps are speeded up far beyond the average, throwing the birds at least 28 yards a second, so that if he found his bird inside of four-fifths of a second and fired it would be 44 yards away from the gun muzzle, a very long range for the 28-gauge. But as that was the gun he knew best, the Kid was bent on starting with it, hoping to make up in quickness what he would lose in range power, for my 20gauge never fitted him very well, kicked him too much with the standard load, and he never hit as well with it at any time during our field practices as he did with his 28. But, to appreciate the handicap he had as compared with a boy of fourteen shooting a twelve-gauge, just remember that the 28 takes $5 / 8$ ounce of shot against $1 \frac{1}{4}$ ounces for the twelve, only half as much; so that he would have to lead and hold twice as accurately.

However, the men welcomed him cordially and looked over the tiny shotgun and its fire-cracker shells with keen interest. The Kid drew position No. 4 in a ten-bird squad and we went out to the stands before all the crowd. He did not notice the people much and "nerves" or stage fright was the least of his troubles. He slipped in a shell, 


\section{FIRST DAY AT THE GUN CLUB 105}

with the gun still broken, and waited while No. 1 fired.

"Now, then, Kid, take it easy and close your gun when No. 2 fires; now cock it and lay it carefully over the centre of the trap house, for No. 3 is firing and your turn is next-now!"

"Pull!" rang out the clear, treble voice. The bird rose, and Pank! went the little 28 before it had hardly begun to soar. The Kid was certainly going fast after them with a vengeance. "Lost!" wailed the scorer.

"Too fast, boy ; you're almost snapping them in your anxiety to be quick." But there was no holding back the Kid; he kept worrying about that 44 yards and wanted to get them if possible inside 35 yards anyhow, so his next turn was a snap almost as fast as the other and a lost bird also. We moved to No. 5 position, for in ten-bird shoots two birds are fired at at each of the five positions.

"Now, kid, this is going to be a mean place; if you get a right quarter you'll have to lead him a mile-and for heaven's sake, take your time!" He got the mean ones all right; one right quarter and one straight away; which at this position is very hard as you have to lead it somewhat, too. Missed them both.

"Now it is time to move to No. 1 position," I 
admonished; "carry your gun empty and open, so that every one can see that it is empty, holding it vertically in front of you, muzzle up. Hurry, now, with your shell and close your gun for your turn is coming immediately," I added, as we got to No. 1 at the left end of the line. Now the Kid slowed down a whole lot; too poky at first, for he missed both birds at No. 1, but when he got to No. 2 and the shooting got easier (for the birds from there do not get away at such terrible angles) he broke his first one. Clean in two, and my! what an encouragement! The next he struck with a single pellet and wabbled it, so it could not be scored, but the Kid was just as pleased for now he was "getting them." At No. 3 he was in the central and easiest position; dusted one and lost the other, a hard right quarter, which bird always bothers him, the Kid being left handed. This ended the first shoot, and the scorer had only one tally to show, but we checked it up as three hits in our minds, for even a dusted target ought to score with such a small gun as a 28. I shot in the next squad with a 20-gauge double brush gun and only got two out of ten with it although I can usually account for 7 or 8 out of ten with the twelve-gauge. Holding high and holding low I spent a number of shots in finding out just where the gun placed its target 


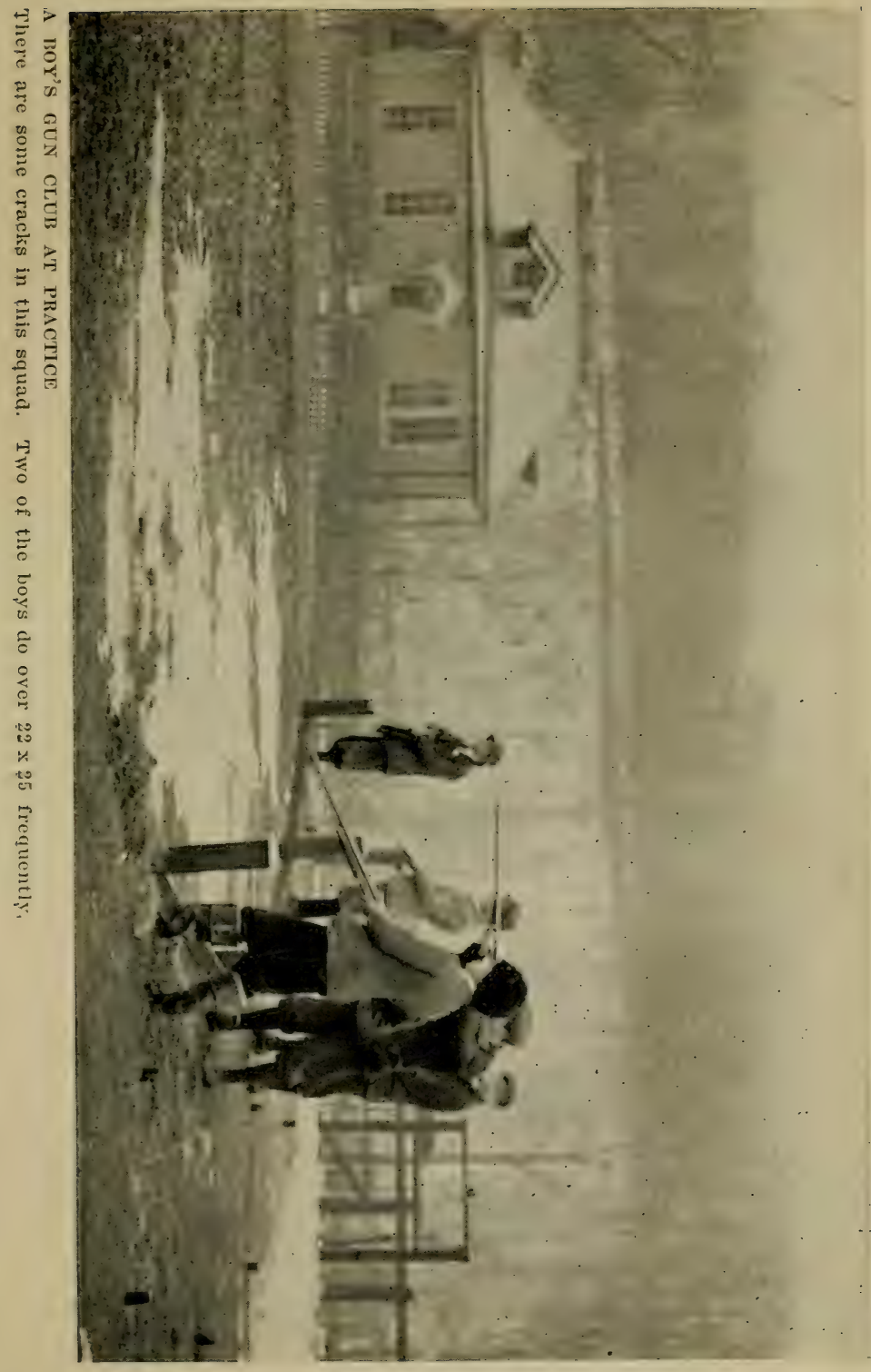





\section{FIRST DAY AT THE GUN CLUB 107}

before I was sure that you had to hold it a good deal lower than with a standard trap gun to get them. Even easy straightaways that were "sure dead" with the twelve, soared away unharmed principally, I believe, because I shot too deliberately. One of our fast men took the same gun later and did six out of ten with it.

The Kid next entered a fifteen-bird squad drawing No. 1 position. I stood back of him coaching as before. Before we went out to the stand I gave him a "once-over" on trap etiquette: "Put those fifteen shells in your right pocket, son, so that you will not have to fumble and search for any of them; never delay the squad firing on any pretext whatever; put in your shell and leave the gun open just as soon as you have fired and ejected the empty; close it and cock it when the second man ahead of you has fired; lay your piece and hold over the centre of the trap house while the man next you is firing; take a last look over the gun and see that it is held straight, not tilted to one side, that it is cheeked correctly so that your breech and front sight are in central alignment, open both eyes, look at the trap house and call 'Pull!',

This time, after missing all three of the birds at No. 1, the Kid got right after them and shot in 
excellent time, smashing two and dusting one at No. 2 ; smashing another at No. 3 and dusting the other two; getting a smashing right-quarter and breaking up a straightaway at No. 4 and missing all three at No. 5. The scorer then had a tally of four broken birds to show at the end of the shoot, and mentally we made it seven out of fifteen, counting in the three dusted and wabbled birds as struck with at least one pellet. The Kid was much elated over his first go at the regular game, for many a man with the twelve-gauge does not show nearly as well his first time. And then a heavy hand was laid on his shoulder and a deep, kindly voice said, "Kid, you did first class with that little popgun; come down again and shoot some more-you'll make a trapshooter all right!', It was the President of the club who had been shooting alongside of him in the fifteen-squad.

And so the Kid walked home on air and clouds, cleaned his pet gun, fed the dogs and vowed that he'd get down every Saturday and have some more of that good sport-you bet!

But now the brown October days were filling the forests with scarlet and gold, the corn sheafs stood like regiments in the fields, and the game laws opened up on quail and rabbit. Setter and hound had been chafing at the delay ever since the Sep- 


\section{FIRST DAY AT THE GUN CLUB 109}

tember frosts set in, and now they galloped out with us into the hunting fields. Quail keep together in coveys of a dozen to twenty-five birds, and the places to look for them are in the corn fields, the brown pea weeds around the edges of old truck patches, and berry and briar patches where the seeds of overlooked berries have dried out and fallen to the ground to be scratched for by hungry quail. The Kid with his 28 and I with the twelve spent our Saturdays in long tramps into the back country, with Scout, the setter, quartering the ground ahead while Pepper, the hound, worked up old rabbit trails in the thickets and woods nearby.

Presently Scout comes to a point. His body stiffens and his spine trembles with eagerness. "Now then, Kid, they're right ahead; you take this position right behind the dog, for at least one quail will fly directly away from him, giving you a dead easy straightaway shot!"

We creep forward as though treading on eggs, guns just below shoulder at a ready. Suddenly, Brrrrrr! up jump a dozen swift, brown bullets, Pop! goes the 28 and Blam-Blam! roars the twelve. "Three down; steady, Scout. Mark! there they settle over by that weedy ditch. Fetch dead bird, Scout!' and the faithful setter noses 
out and brings us, mealy-mouthed, the three brown beauties. " "Nice clean kill, Kid," I comment.

We walk over toward the ditch and again Scout points.

"Ready, boy!" We edge forward, trailing the right foot on the ground, for if that foot is in midstep when they rise, you lose the instant required to put it down again and take firing position, probably losing the bird also. "Where are they, anyway?" For a creep of twenty feet raises nothing. Scout makes a short dash ahead and again stands rigid. "They're roading; come on, along the ditch!" We work up much faster, and this is too much for the scattered covey who rise like a thunderbolt here and there and head for the woods. Bang-bang! Pank! "Missed that fellow clean, Kid, he caught you with that foot off your guard. Reload now, and we'll follow them into that thicket over yon."

"Pep's got a rabbit, father; hear him yip and bay.' Pepper certainly was making the woods ring, and we ran over to the catbriers at the edge of the woods, for the rabbit would certainly circle, and might run out into the field if he did not make for these briers. The chase worked around our way, punctuated with the yelps of the eager 
hound. "There he goes! Run up that log road, Kid, and you'll get a shot; aim high; lead him a mile and take him at the top of his jump."

Rabbit is not easy to hit, but one pellet of tens will settle him if you land it. Often you must fire from the hip, and never is there a chance for a decent aim, lead what you can see about a yard.

Borp! rang out the 28 under the wood aisles, and "I got him! Le'go, Pep; you houn' dawg! Git away f'm here!" shrilled a treble voice. The Kid was full of excitement and talking a triumphant string of adjectives as he came down the road, dangling a long furry cottontail, while Pep jumped all around him. We then started across the fields for the thicket where we marked down the quail, and in an old turnip patch Pep struck another rabbit trail, gave tongue and was off.

"Let him go; we'll attend to birds for the present; hang that rabbit to your belt, Kid." Scout had no use for rabbits; he knew that to follow them meant a licking so he was broken, "rabbitproof" as the dog men say. He galloped across and across the field ahead of us and presently made game.

"A single, by George! Easy, now, he's frozen." Scout lay down with his head canted rigidly 
upon a tuft of weed. "Hiding in there, by jingo! Now give him time, Kid, or you'll blow him all to pieces." We walked forward until almost on top of the hiding quail. I made a kick and Brrrrr! away he went low down and straight as an arrow. The Kid let him get twenty yards away and then bowled him over as if struck in the head with a brick. Scout had him to bag in one jump.

"Lone bird, I reckon; here we come to the thicket."

But the covey had either flown farther or had run through the leaves and got into the swamp, for Scout failed to make any game. We kept on, up into a little, moist leaf-strewn ravine and here the dog came to a shivering point. "Gee! he's excited this time, Pop. What is it?"

"Don't know; easy ahead, now." Suddenly Weet-weet-weet-weet-!! a swift flash of wings up through the bare branches, and both guns spoke. Two birds fell; "Woodcock! by all that's holy! Kid, you've killed your first woodcock!-shake!" We picked them up and called it a day. Five quail, two woodcock, and a rabbit; enough for a game supper, and outside of big-game hunting and wildfowling, there is no better sport. Which is only another way of saying that, no matter what 


\section{FIRST DAY AT THE GUN CLUB 113}

you hunt in those grand months of the year when the Hunter's Moon is shining you will have a thrill and a zest in following dog and gun that no manmade game can begin to approximate. 


\section{CHAPTER VII}

\section{A DAY IN THE UPLANDS}

The Boy did not often go down to the gun club with his 28 in the fall months, in fact the gun club itself put up its shutters temporarily, for the royal month of November was in full swing and every member was off shooting. One or two tries at ten and fifteen birds at the standard trap ranges with the 28-gauge shooting tens chilled, resulted in too many "dusted" birds to be encouraging. We could see the clay saucers jump and hop as the shot struck them, but only a few broke so as to enable the scorers to mark them up as "Dead!" And the brown uplands, the brown marshes with their wastes of gray waters were calling, calling for The Boy to come out afield and try the 28 on rabbits and ducks.

We decided to let the traps alone for the present and come back when the tournament season should begin again with the big Thanksgiving shoot. One bright clear Saturday, early in November, the Boy and I rose before dawn, piled into an auto 


\section{A DAY IN THE UPLANDS 115}

already crammed with sportsmen and dogs, and the whole works buzzed off into the back country with the freezing wind whistling about our ears. An old barn near a great rabbit and pheasant swamp was our objective, a "swamp" in that country meaning a dense thicket of brush and timber intersected with numerous streams. Three men, the Boy, three beagle hounds, one fox hound and three "pocket" hounds tumbled out of that automobile and we all jointed up our shotguns. It was great country to hunt in; tall brown weeds choked the fields and tangles of thicket jutted out here and there wherever a little rill worked out of the fields into the woods. We formed in a long line, with the dogs snuffing and quartering the ground in advance. The first shot roared out within ten minutes of the time when we entered the first thicket. It was Charlie, on our extreme left, who had put up a fine cock pheasant in a dense catbrier thicket. A beautiful shot, snapped from the hip; and as handsome a bird as you ever laid eyes on. These are State-planted English pheasants, a lot being liberated every year so that there are a few of them to be found in almost every big tangle of brush of four or five square miles in area. Suddenly, over in our centre, one of the "pocket" hounds let out a yip, and immediately Brownie 
and Spot, the beagles, joined in, and then came Pepper, the foxhound's deep bay. Then-Spank! went the twenty-eight from the depths of the thicket, and the Boy's clear yell, "Missed himby gorry! He's a big fellow and going like sin!"

"Run, everybody!-out for positions on the road! You come out here, Kid, and stand where you can command the edges of this field, for he will surely circle back and you'll get a shot."

The rest ran out on the main road and strung out a hundred yards apart, while I tore up a backwoods road on the chance that the chase would head that way. Things were lively enough in the thicket; the continuous yips of the small hounds, the screaming yelps of the beagles, and the constant baying of Pep told that the rabbit was in sight ahead of them. Hither and yon it circled and doubled. Presently there was a faint rustle in the brush near my position and a large rabbit hopped out, saw me, put on a raft of power and beat it into the brush. But the old Parker barked out and rolled him over and over-the deadest rabbit since Lazarus' time! Along came the hounds in full cry, following every double and sidestep until they ran right over the spot where I had picked the rabbit up, proving that he was the one that had made all the trouble. 


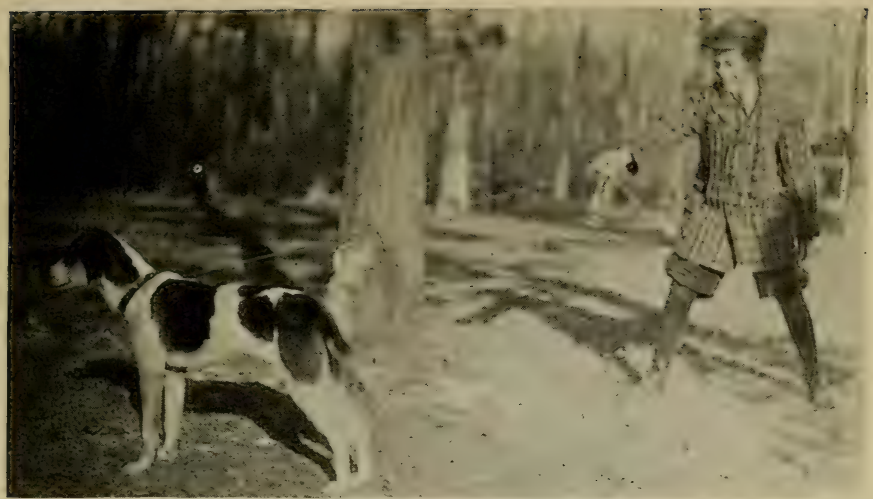

PEPPER AND THE KID STARTING FOR A RABBIT HUNT

Note: Pepper's tail is not docked; he has only wagged it out of the picture.

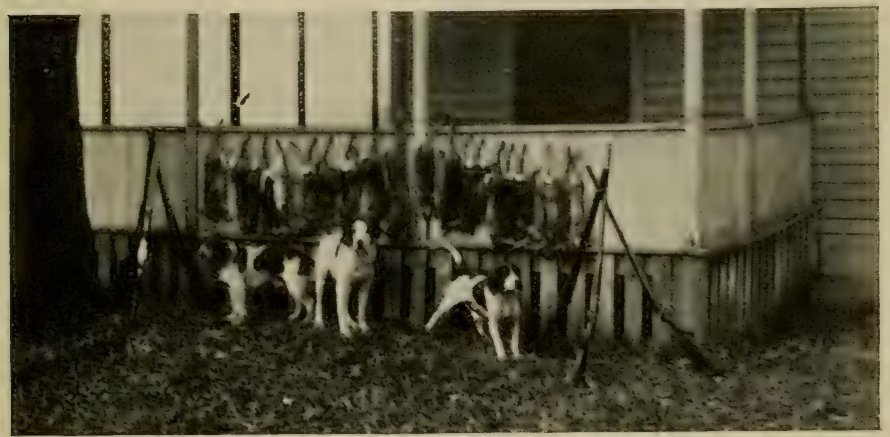

OUR BEAGLES AND SOME RABBITS

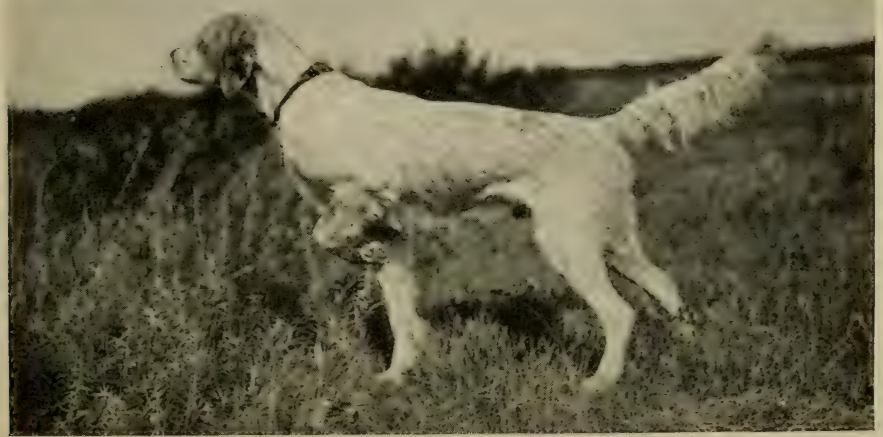

A SITTER, POINTING A BEVY OF QUAIL 



\section{A DAY IN THE UPLANDS 117}

Into the swamp again, everybody; twisting and turning and dodging briers and crawling under and through alders, always with the gun at ready for any moment a sudden roar of wings would denote a flushed grouse or pheasant, or a bobbing of white tail would tell of Molly Cottontail on the move. Then, off somewhere in the bushes, a little pocket hound-Beauty it was-squeaked, and then her mates, Punch and Judy, took it up. Pep had been snuffing among the leaves near me; now he whined approval and was off on the jump for the spot. Then a ripping, tearing bray told that Spotty had taken the trail and another rabbit had been started for the stewpot. This time the Boy out in the field was the lucky man. Bunny came tearing out, looking neither to right nor left, with the eager dogs not fifty yards behind him, and the Boy put his sights well over him and pulled trigger, bowling him over neatly.

We now crossed over into a great ravine, full of tall timber and not much clogged with underbrush. The brown, fragrant, autumn leaves crackled crisply under foot, the keen Northwest wind sang overhead and it was good to be alive and afield with dog and gun! The hounds threaded their way through the forest, snuffling tracks in the leaves. We worked up a big ridge and down into a ravine 
grown up with catbrier at its head. "Now, look out, kid, this is a likely place and we ought to start something," I admonished. "Cock your gun, but don't forget to uncock it again when we get into less likely country.",

"'There he goes!"' yelled Frank, and Bang! went his Winchester pump. "Got him! Look out, you fellows, there's another coming down your way!" The dogs all went wild at the gun report and rushed to the scene of the kill, and Frank soon had them on the fresh scent of the other cottontail. Down they all tore through the timber, but that old fellow was too foxy and made good his escape by a side jump and a double. Then, from out the field at the head of the ravine, came the unmistakable pop! of the 28-gauge. "What did you get, Kid?" I yelled.

"Quail!" chirped the treble voice. "Come out here quick, there's a bevy of them!" We all climbed out of the ravine. "Oh, pop, he was a dandy shot!" crowed the Kid, holding up the quail. "Got up out of the grass by that old grape vine and I knocked him just as easy!"

"Where did you mark the rest down, son-he's a nice one, fat and full feathered-",

"They lit over in that field beyond those chicken sheds, Father."' 


\section{A DAY IN THE UPLANDS 119}

"Well, let's get them up before the hounds get back and flush them; we sure ought to have brought Scout, the setter."

We formed in a line beyond the abandoned chicken sheds and swept up the field. Then, over on the right near the woods. Brrrrr!! up got the covey and Blam-blam-bluie-bluie! ensued. The Boy and Charlie on the right did the honors with a single and a double; the rest of us were too far away to do anything but mark down. I spied two, making off through some green tops of small pitch pines, and was off after them with gun at a ready. The going was uphill, with the view finer and finer at every step, but just then I could spare no eyes for anything but quail, for without a dog they get up so unexpectedly as to make a hit in the brush a hard matter. The first one waited until I was within four feet of him and then jumped and whirled right past me downhill, so that I had to turn completely around to get a shot, as, when circling so near me, to shoot would either be to miss entirely or to blow him to mincemeat. By the time the gun was following him he had gotten through the pine tops again and I scored a miss anyhow. I met the Boy coming up with his second quail. "He went right down into that valley in the woods, pop," said he. "Let's go get him." 
"This is going to be some hard stuff, Kid, and I want you to take a try at it. Any one who can get his quail in thick brush is some shot, as the little rascals are quicker than a grouse to put a tree between you and them. You take the lead and try your hand."

We worked our way down into the leaf-strewn valley. Oh, for Scout and his infallible nose! "Careful, now; he pitched down about here and will not move far at first. Easy, now; keep your right foot on the ground and trail it, for he's likely to jump any minute-there he goes!' The Kid flashed his twenty-eight to shoulder but the quail had dodged as quickly, and he scored a miss, while I got no chance at all at him until he was sixty yards off and going like the wind through the tree trunks. "Better fire and miss than not fire at all," as the old saying is, so I reached out for him with the full-choked left, but did not draw a feather.

"Well; he's earned his liberty, Kid; hear the row the dogs are making over there to the north. I'll bet that catbrier swamp is plumb full of rabbits!"

We hastened over through the woods, the yells and squeals becoming more complex every minute. "Pop, they've got a dozen in there!' exulted the Boy, changing his load from tens to $7 \frac{1}{2}$ 's as he 


\section{A DAY IN THE UPLANDS 121}

ran. We ripped through a tangle of briers as high as your head and-started a rabbit on our own hook! The Kid got him, firing from the hip as he bobbed underneath the briers. But all the dogs were barking stationary, and when we got there Frank and Charlie were forming a mining company limited, with a crooked pole, all three "pocket" hounds were completely out of sight in the earth their barks coming up like muffled throbs from below ground. Brownie, Pepper and Spotty were digging like mad, and a rank musky odour came out of the hole. The lair was under the roots of a huge overturned stump, a monarch of the forest that had once dominated this gully and whose removal had caused the growth of catbrier brush and the thicket of saplings.

" 'Coon or 'possum-or I'm a Jew!" I pronounced, sniffing the hole. "We'll have to smoke him out." If 'coon, the dogs had evidently caught this fellow out late away from his tree, for they usually leave the swamps for the forest fastnesses very early in the morning. If 'possum, it was doubtless his regular lair. The first thing to do was to get those pocket hounds out and leashed up. Built like a miniature beagle, the peculiar excellence of these little dogs is their wonderful nose, their ability to get through brush and briers that 
no beagle or foxhound would care to tackle, except on extremely hot scent, and their ability to work into almost any ground hole. Beauty, Punch and Judy were all up in the bowels of the earth somewhere, burrowing and barking like mad, and to get them out seemed hopeless. However, each was negotiated' at arm's length by his own tail, and soon we had a smudge going, while a ring of dogs, men and the Boy awaited results. It did not take long; suddenly out of the hole burst a grey furry streak, followed a jump or so behind by all the frantic hounds. Then he turned and fought them, screaming and biting savagely, his high, shrill squall rising above the babel of hound voices. But the dogs killed him in less than fifteen seconds, old Pep getting a throat-hold and shaking the life out of him; a smallish raccoon of about 5 pounds weight, but constituting the best trophy of the day, so far, besides the cock pheasant. We foresaw a roast 'coon supper for the crowd, and the pelt was voted to make a hanger in the Boy's den.

After this we went back to the barn for lunch, and the fry-pan, bacon, hot coffee in thermos bottles, cakes, sandwiches and apples made a welcome feed. "Now, who's my friend when lunch time comes?" chirped Charlie the Quick, when the 


\section{A DAY IN THE UPLANDS}

hounds crowded around him for tidbits and scraps. It is not well to feed them but a tiny bit until the day's hunt is over, for each dog will promptly curl up and go to sleep until he has digested the meal.

We next piled into the auto and ran for another famous swamp, where there were pheasants and rabbits and a few grouse known to be. It lay two miles inland from where we were, and was in the shape of a triangle a mile on edge, with a wood road, a sand barren and a cabbage and brier patch on the three sides. Here we put in the dogs. The dense huckleberry brush made the going under the pines and oaks nearly impossible, but if you fought your way through with ready gun you might be rewarded with a ruffed grouse. Another very good place for them was the wood road mentioned before; all grouse love the old lumber roads because they find here spots to dust in and because there is there a sparse growth of forest grass, occasionally some oats sprung up from ancient droppings of oat feed by the lumber horses. The Boy and I decided to try the old road, leaving Charlie and Frank to guard the cabbage patch and sand hills. The dogs hadn't started a rabbit yet, nor had any thunder of wings told of their flushing a grouse. We followed the old road under the 
pines. The last wheel-marks made here were buried deep in pine needles and dead oak leaves, while scanty growths of huckleberries had already gained a foothold, and among these I peered sharpeyed for the brown neck and dark ruff or collar of the grouse.

"There's one, Kid! Just crossed the roadwent into those bushes at the left!",

"Where! where!" exclaimed the Boy breathlessly. "I didn't see a thing."

"Have to have an eye like a hawk for game to get your share of it, these days," said I grimly. "Now start in by that bush and work up with your gun just below shoulder, for he'll jump like a flash." Suddenly with a roar ten times louder and more startling than that made by any quail, the grouse flushed, and instantly rang out the crack of the Kid's ready 28. I caught a glimpse of a large brown bird, sailing through the trees with fast-fluttering wings, and laughed.

"Missed him-oh, I'm a dub!" wailed the Boy. "And he looked easy, too, the way he got up."

"You hit him, all right; I can tell by the way he flew-what did you have in?",

"Eights or $7 \frac{1}{2}$ 's, for rabbits, I'm not sure which."

"Those boys will fly with eights in them as long" 


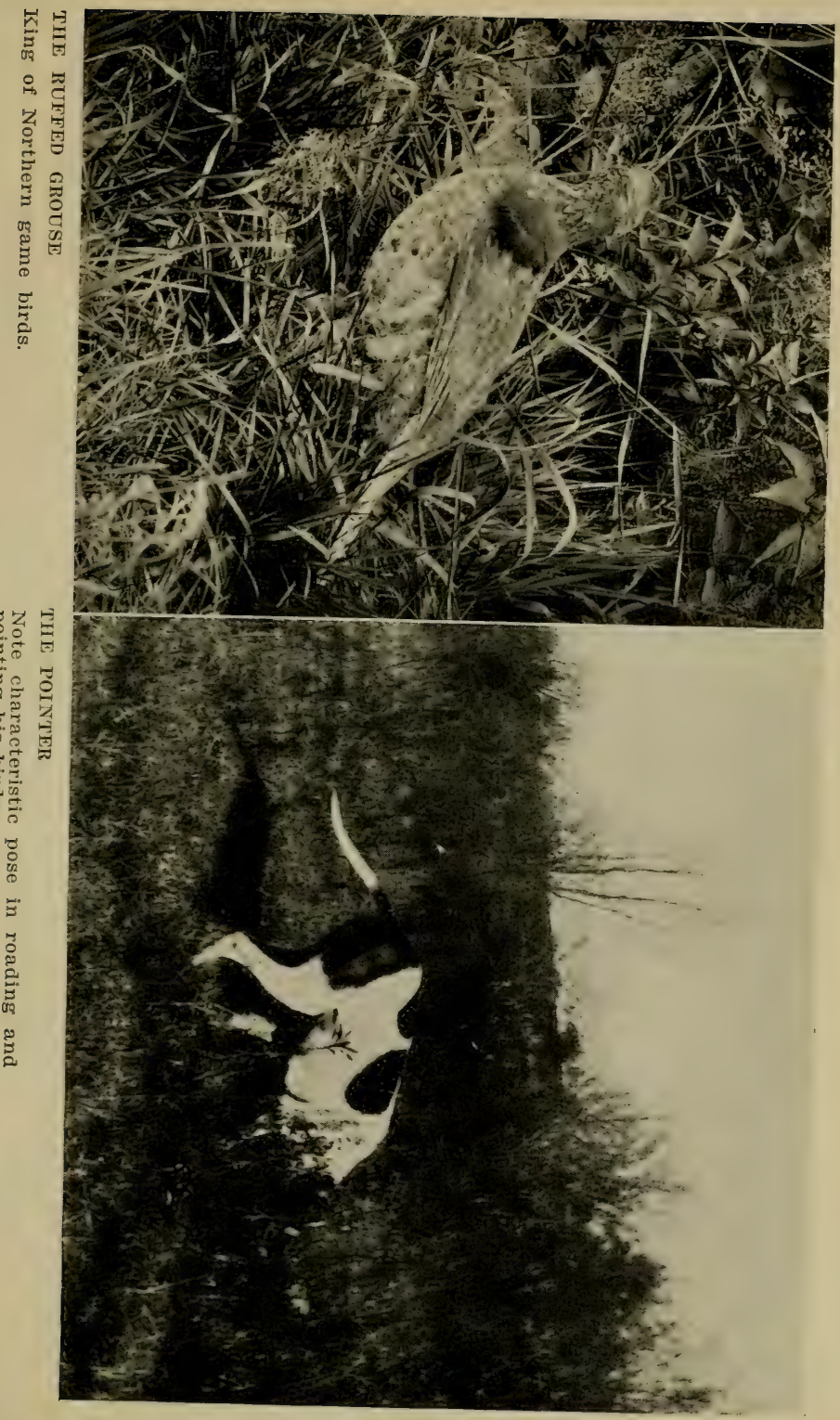





\section{A DAY IN THE UPLANDS 125}

as they can move a wing. We'll look for him; I marked where he went down."

We followed the course of the grouse when last seen, down into a choked and tangled huckleberry swamp, both guns at full ready for either a fresh flush if not hit or an expiring flutter if already wounded. Across this we waded and fought, and thence into a dry pine slope where presently a quivering that attracted us in the leaves disclosed the Boy's first grouse.

"The best prize of the day!" exclaimed the Kid, holding it up proudly. "Gee, pop! I'm going to mount him myself. Some trophy for the den, eh! My first grouse!"

Charlie and Frank each got a rabbit out of that swamp after a long afternoon's work by all the dog's, for it was almost impossible to be at the spot where Molly came out at just the right time to be ahead of the hounds, in trying to guard such a big front with only four of us. At no time did fortune favour the Boy and myself but the eager music of the dogs as they followed the screaming scent up and down and around the big triangle was fun to hear. But we were content, when about four o'clock the sun went down and we whirled back home in the calm of a November evening. And just such a hunt as I have described, the kind that 
we take, with variations, every Saturday during the hunting season, is entirely possible to any set of boys in almost any part of our country where the game is reasonably protected.

But, as the whisper of "Ducks at Barnegat!" began to grow louder the later it got in November, we decided to go down there for a camp and a duck shoot after the next big northeast storm; and so the Boy went down to the traps to practise with $71 / 2$ 's in his 28 -gauge shells, for 6 's would be the smallest shot permissible with ducks and he would have now mighty few pellets to rely on and must send them straight indeed. 


\title{
CHAPTER VIII
}

\author{
SHORE BIRD SHOOTING
}

\section{"MARK south, papa!"}

Every one froze in the blind, for when the Kid called "Mark!" it always meant that his bright blue eyes had seen game coming. Rigidly we crouched in our circle of sage, not daring to move a muscle, looking cornerwise out through every vista available while thrills of anticipation raced through our nerves. Up, out of the south, they came, suddenly being visible in the vast greenness of the marsh, a shimmering of white underwings and a wheel of grey pinions as they circled the decoys down-wind. The safeties clicked and I heard the hammer sear of the Kid's 28-gauge clink home as every bird cupped his wings and hovered over the stools.

"Now!" gritted Walter through his teeth. Crack! spoke the little 28, and Blam-blam! Bluiebluie-bluie! roared the double and the pump. Birds crumpled and fell right and left as the flock flashed into lightning action, bursting in every direction like a feathered bombshell. 
"Down! Every one!" barked Walter, grabbing the Kid's shoulder and forcing him to earth as he fumbled for the bone snipe whistle dangling at his neck. We crouched motionless while the shrill Dzree-u-ee! of the black-bellied plover call floated out over the marsh. But the flock would have none of us, and would not return for any snipe calls, however seductive.

"Seven down!" called Walter, wading out to pick them up. "Say, these are the queerest blackbellies I ever saw! One-year birds, maybe; I dunno." He brought in the bunch of large black and white plover, their wings dangling all awry, and tossed them on the tarpaulin floor-cloth of the blind.

"Where's the hind toe?" I demanded, examining the legs of one of them. "Black-bellied plover, nothin'!- these are young Golden Plover, man! Glory be! the first I've seen on these marshes in many a weary year!"

Walter grunted incredulously.

"In the first place, the herring-bone on their backs is too yellow for black-bellies, even first-year birds," I argued. "In the second place, where are your black feathers under the wings nearest the body? And, in the third place, the hind toe is wanting, and that settles it!" 
"I believe you, my boy!" said Walter with rising exultation in his voice. "Who says the game is not coming back! This is only the third year of that no-sale-of-game law that you fellows put through, but I tell you I never saw such an increase in all kinds of snipe, duck, and geese in this bay as has come this year and last. Those are the first golden plover that I've seen in-let's seewell, sixteen years anyway."

We three were out for a shore bird cruise-a week's end from Friday to Tuesday, in September -shooting snipe on the marshes, fishing the hole at Jones' Inlet for big tide-runner weakfish-the kind that run six to eight pounds-and tackling the surf at night for kingfish and blues.

This morning we lay in the balmy sunlight with a comfortable black oilcloth spread under us on the marsh and nothing to do but talk and keep a bright lookout through the interstices of the blind for passing flocks over the rim of the far horizon, shimmering green and lovely in the mild heat of autumn. Every fifteen or twenty minutes the tense call, "Mark southeast!" would arrest all movement and send one's fingers sliding ever so gently along the tang of the shotgun to where the knurled ridge of the safety jutted up. Millions of peeps and sanderlings hovered about or played 
among our decoys unmolested, and now and then a flock of big birds would visit us; one time three incoming willet, that flew high overhead, presenting the hardest kind of a shot; another time half a dozen summer yellowlegs, who wheeled in to our cheerful hu-hu-hu's; again, a couple of creakers, who flashed in unperceived until right over the blind, and then were handily picked out of the air by a left quartering double made by the writer, and causing him a four-inch expansion of chest measure!

But these golden plover were "something else again," the finest eating and rarest of all plover in the East, and there seemed to be quite a few of them using here and there in the marsh. When you realise that that marsh is some twenty miles long and ten wide, it meant that our chances of being visited were so infrequent as to cause a bright lookout for the least sign of a fluttering wing on the horizon and a sharp ear for the faintest suspicion of a snipe call floating over the marsh.

The morning wore on with varying thrills and now and then a long sunny spell with nothing to do but loll in the blind and enjoy the salt tang of the southeast breeze blowing in from the open ocean. Finally Walter went out of the blind-fatal mis- 
take, for something always happens when you are not attending strictly to business-and in less than five minutes a sudden "Hist! Mark southeast, papa! Look who's here!" in the Kid's clear treble, made us both bow flat to the earth, for this time a big flock of black-bellied plover were approaching, as we could tell by their white rumppatches as they wheeled up-wind. They didn't like Walter's huddled, motionless form and alighted, just out of range, across our pond.

"Kid, if you dare bat an eyelash I'll massage your dinner basket with the butt of this shotgun!" I whispered to the excited boy, who was cautiously edging the blue barrel of his little weapon out through the scrub. The flock played, gamboled, pecked at each other and chivied one another about, occasionally dipping their bills in deep in search of small crustaceans; but they kept off about forty-five yards and seemed to be working gradually away from our dumb decoys. Out of the corner of my eye I saw Walter executing an incredible flank movement in the face of the enemy; humping along flat on the wet marsh a yard at a time, he was working into a position where the birds would go towards our stools by preference, giving his strange and unusual shape a wide berth as always. Gradually they played and fed over 
until they were fairly among our wooden effigies, and one of them even pecked peevishly at a toothpick bill.

"Ready, Bo," called Walter out of his left ear. "Let the Kid fire first, and you take those two on your end-Now!",

Like a flash the Kid was on his knees, and Spank! went the 28, dropping the bird nearest, while Walter and I crashed into the main flock. Five crumpled up, while Walter knocked over another as the flock was whirling out of range, passing him up-wind, as is their invariable instinct.

"Fine teamwork, old top! Eh, what!" I called as Walter waded out to gather in the slain. "Six down, or I'm a Jew!'”

"Wait till they've hung a day or so and I get a chance to make you a béccassine à la risotto out of them," grinned Walter, stumbling in with the dangling birds. "You'll wish the whole earth was plover and you had to eat your way from the centre out!"

Back in the blind again, while quiet settled over the whole vast marsh, with its thousand ponds basking placidly in the sunlight. Now and then the querulous call of a gull would raise all the heads in the hide expectantly, only to drop again when a glance at the wing motion assured us it was 


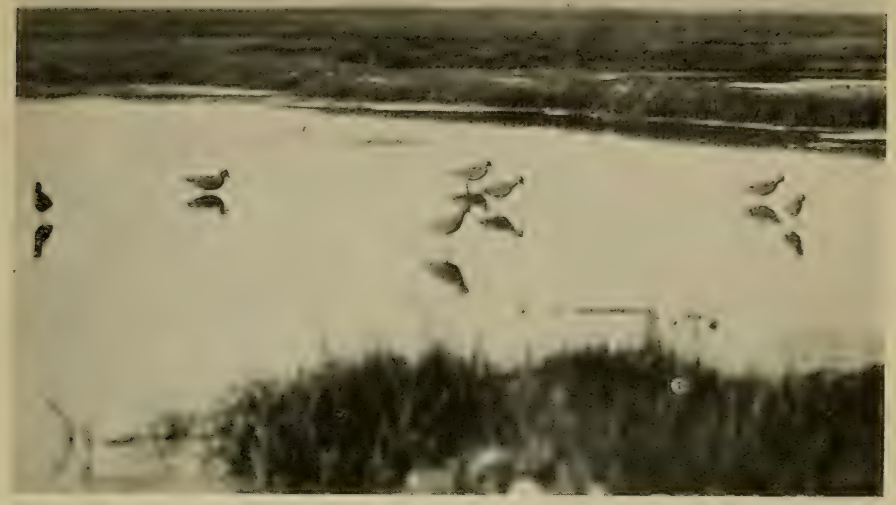

SNIPE DECOYS SET OUT

They should go 18 yards from the hide to the farthest snipe, should face up-wind and not be hunched too much.

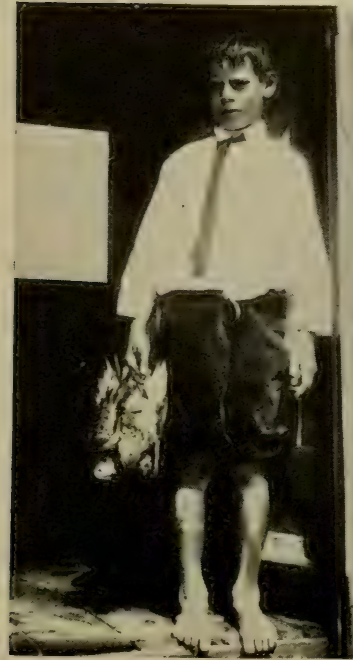

THE KID AND.

SOME OF IIIS PLOVER

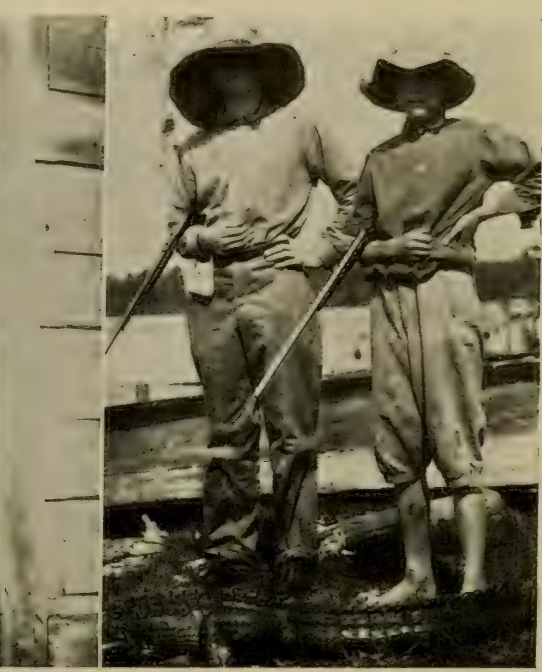

AN ALLIGATOR HUNT

Killed with a .22. 



\section{SHORE BIRD SHOOTING}

not a willet. Walter sniffed the air uneasily. "Man," said he at length, "I've never yet seen conditions so exactly right to fish the Hole as they are this morning. The tide is just starting to ebb and the wind is making up strong out of the southeast. The birds are about done for the day, so what do you say to an hour's fishing the Hole and then get grub for-",

"Mark southwest!'"-thus the humble historian of these events, who owns the longest ears on any animal save a donkey, and had heard the liquid notes of a tattler or greater yellowlegs abroad in the marsh while listening to the above exhortation with the other ear. Now a quick flash of wings on the far horizon caught our eyes and everybody crouched.

"He's at least a mile off, but I'll try calling him," muttered Walter, raising the bone whistle to his lips. Hu-hu-hu-hu! drooled the call, and presently the answer sounded, nearer, and we saw the foolish bird, still nearly a mile away, turn from his course and rush to his doom to the tune of our seductive blandishments. Walter redoubled his efforts. "Wouldn't sell this old pipe for a million," he ejaculated between calls; "made her myself, and the tone is just right. Here he comes-down! you beggars!', 
The big fellow cupped his wings and craned his long neck down over the decoys. "Tsearp!" chirped Walter, coaxingly. " "Come on in, the feedin's fine!',

But either the Kid or I must have wiggled a fin or flickered an eyelash, for suddenly, with a suspicious swoop, the big bird put on a raft of power and whirled by us like an express train.

"Shoot!" barked Walter. I blundered to my knees, fumbled the gun to my shoulder, took a long, careful aim, and scored-a clean miss!

"Je-hos-o-phat!" exploded Walter, "but you were slower than running mo-lasses with that bird! You hung over that aim so long I thought you would finally decide to take it home with you and petrify the pose for a keepsake!"'

"I wanted to make sure of him," answered I meekly enough. "He certainly went by like a bat out of-well, let's go fish the Hole!"

For answer Walter waded out and gathered up the decoys, stepping over his boot-tops in a hidden marsh hole and adding much to the hilarity of the occasion thereby. I picked up the slainfive golden plover, seven blackbellies, two creakers, seven yellowlegs, one willet-and put them and the shells in the tarp, while Walter and the Kid followed me to the boat with armfuls of decoys and 
guns. We apprehended the duckboat and pushed off to the Ladybird. There was a strong sea on, rolling up Jones' Inlet, and I foresaw squalls ahead for the Kid, who was addicted to seasickness.

The guns were laid on the cabin roof, so as to be handy for passing shots, and Walter went below for the basket of shedder crabs for bait.

The tackle rig is a stout three-way swivel with a 4-ounce pyramid sinker on a 9-inch line at the lower end of it, the 18-strand main line at the upper end, and a strong twisted gut leader a yard long: attached to the middle loop of the swivel. This leader may have one or two hooks, as preferred. It is imperative to cast at least a hundred feet from the boat if you want big fish, and the water in the Hole is 27 feet deep, with the tide scouring into it like a mill-race; so light tackle is out of the question. I once tried a standard black-bass baitcasting line in the Hole, but-never again! You had to "play" even an ordinary sea crab harder than a two-pound bass to land him, and every big salt-water fish that took hold broke the 12-pound bass line I was using.

Be that as it may, we three rigged our surf-casting outfits and baited up as soon as possible. Walter and I cast two hundred feet from the boat, 


\section{6}

\section{SHOOTING FOR BOYS}

while the Kid, with a light boat rod, fished directly under the Ladybird for flounders. He also was the first to report a bite. An unmistakable yank on a rod that refused to budge told us that he was anchored into a big fish-and then a prodigious "hurrah's-nest", broke out below! The Kid could not turn the reel handle during the fish's rushes, but he could thumb the reel spool, and he stuck to it like a puppy to a root, with the rod butt under his armpit and some of it sticking out beyond his shoulder-blades.

"Gee, papa, how he pulls!" would come the perspiring bulletins as the red-faced 11-year-old cranked away at his reel during the intervals when the fish wasn't bent on taking soundings to the bottom of Jones' Hole. Finally he came to the surface and Walter netted him deftly, a big flounder a yard long that went five pounds flat.

The Kid swelled with pride as he beheld his vanquished foe flopping about in the cockpit. "Gee, papa!" he burbled, "that's the very biggest fish I ever caught in my life!"

"I'll grab his grandfather for you in a jiffy," chirped Walter, despatching the flounder with a club, and he picked up his rod, took a feel of the tide-strain on sinker to assure himself that there were no crabs chewing his bait, and resumed his 
attitude of tense expectancy on the engine hatch in the stern of the Ladybird.

Presently, "Whoa, there, you Betsey Jane!" We all watched him and distinctly saw the second faint tug which denotes a big tide-runner weakfish taking hold.

"Now, you Betsey Jane! you behave yourself !" said Walter sotto voce, scolding his rod as if it were a pet dog. Yink!! The Kid's fish was as nothing to this baby! Nearly two hundred feet from the boat and twenty-seven feet under the waves, he slashed the line through the water like a ripsaw, circling and summersaulting about, while the master-fisherman at the other end of the debate gave him line when he got too fierce, and reeled him in, inflexible as Destiny, the rest of the time. As he neared the boat the action became swifter and swifter; he circled the duckboat, forcing Walter to pass his rod under the painter of the latter; he had to be held back by main strength from taking a turn about our anchor rope; he dove under the power-boat, wrapping the stout Betsey Jane around the Ladybird's bottom; he bored straight down for the depths of the Hole, tugging the line foot by foot and yard by yard from under Walter's reluctant thumb; and pandemonium broke loose by the yellful as I finally 
scapped him and Walter beat his brains out in the cockpit with the oaken billy.

"Eight and one-half pounds and as long as an oar," announced he, holding up the scales, while the Kid stood around with popping eyes and openly adored him. It was a big ocean weakfish - thirty-one inches of iridescent silveriness, gorgeous with red and pearl and opal scales flashing in the sunlight; the sea trout, one of the most beautiful fish that swims in the ocean and as unlike the little quarter-grown bay weakfish in his fighting powers as bass is unlike perch.

All this time my line had received no more attention than a flea on a pig, and Walter had more than once broadly hinted that it was about time that I began catching something else besides seacrabs and festoons of seaweed. The Kid had added two more flounders to the mess-where was his dad coming in on this as a meat man, he would like to know! They were just about promulgating a rule that no one should eat any fish except those he personally caught, when something pounced vigorously on my line and began flirting about the Hole with it.

"Kingfish!" pronounced Walter. "I can tell by the way he took hold of you. Don't lose him -that's our supper you've got there, man!' As- 
suming this tremendous responsibility, I played him in without incident, considerably disappointed at the meager fight he put up. But Walter was overjoyed as he weighed up the $3 \frac{1}{2}$ pounds of barred brown and lavender kingfish that we lifted from the net. "Now we'll have the finest feed you ever flapped your lips over!" quoth he. "If there is any better eating fish than the kingie, I have not yet come up with it. This bet takes in all trout and bass, as well as the whole salt-water tribes!"

Unaccountably the fishing went flat in the Hole after my kingfish came aboard. Walter could not understand it, as minute after minute went by with three idle lines going. "Never in my life were conditions better for good fishing, and I sure can't make this out!" he averred. "With the ebbing tide all the big fish come off the flats and make for this hole to get the tide scourings, and with the wind as it is we ought to get some good fish. I sure want to see that kid of yours fast to a big fish!' But still they refused to bite, and an hour went by, while a state of somnolence crept over us. "Better start dinner, Walter," said I. "There's nothing doing here-_"

"There isn't, hey? Look at my line, will you! Look at that!--whoa, there, you Betsey Jane!" Walter's line was creeping steadily out, a yard at 
a time, and now he struck savagely. "Get your camera, quick! I've got the whole U-nited States on the other end of this here!"

I dove below and soon brought up the camera, cocked and primed. Four times during the fell fight that ensued Walter was almost yanked from his feet into the sea, and as many times I tackled him around the waist from the cockpit and held him on for dear life. At the end of fifteen minutes the big fellow was still going strong, in huge circles about the boat, while the reel steadily worked him in. "Get the gaff, fellah!" gasped Walter"for'd-under the-starboard-bow deck!"

I heard squeals of excitement from the Kid as I hurriedly ferreted out the gaff from the mass of decoys, crab-nets and fishing "props" under the bow, and rushed on deck in time to see a fish five feet long swimming alongside. A swift strike of the gaff and we had him impaled, and the two of us hauled him aboard, biting and striking, a big shark with malignant green eyes and teeth like a wolf. The gaff was our only control over him, but to that I held with an iron grip while Walter stabbed him with a hunting knife and the Kid clubbed him with the billy. Then Walter got a toe-hold on his tail and I withdrew the gaff as he swung him aloft with a giant swing and brought 
down full force on the cockpit coaming. Then we returned him to his relatives in the fishy deep.

"And that's the reason why there has been no fishing for the last hour!" declared Walter, as soon as he could get his breath. "That 'sooner' scared every fish out of the Hole and there won't be any more until the next tide." He reeled in as he spoke and went below, whence sundry savoury odours and inviting sizzlings soon spread a ferocious appetite about the cockpit. We became too feeble to fish and, in fact, used up the very last of our strength in staggering down into the cabin, where, sitting face to face with a great pot of coffee, a pail of creamed spuds and two square feet of fried kingfish, soon brought us to again. The cabin pitched and rocked like a Coney Island tumbler. Walter and I, having cast-iron digestive apparatus, warranted not to hop, did not notice the reeling and tossing in the least, but the Kid turned yellow about the gills and the cabin was all moving walls to him. Presently he left hurriedly for the outer ramparts.

"S'Smatter, Kid? What's coming off out there?" I called with paternal solicitude.

"Chummin' (hic) for weakfish, papa," chirped the game youngster, who would have his joke, even in the throes of death! 
"Guess we'd better up anchor and make for the Shack," vouchsafed Walter, "or we'll have him down with a bad headache. It's past three now and we have ten miles to go."

Without losing any further time I snubbed up the mudhook while Walter groomed the engine, and presently we were under way, speeding up this channel and down that, through the endless labyrinth made by the green islands of the marsh. Our objective was a little board shack put up by Walter some years before near the Pass, a famous duck wingway leading in from the ocean-front dunes to the marshes. Only those who have been there can realise the vastness of this great archipelago of marsh islands, the whole forming one green expanse, with the channels out of sight between them, so that ships and boats seem to be cutting their way through the solid marsh. At first our shack was a mere black tooth jutting up on the far horizon, but as we spun along down the intricate map of waterways, known like an open book to Walter, keeping all the while a sharp lookout for snipe flocks, we gradually brought it nearer to us until it was only about a mile off in a direct line.

Suddenly, "Holy Mike! Mark north!" I yelled, pointing across the marsh. "Only look at them, 


\section{SHORE BIRD SHOOTING}

man, dear!', They were as big as gulls, but their wings fluttered like winnowing machines and there must have been at least fifty of them in the flock.

"Jack curlew!"' barked Walter excitedly, shutting off the engine. "Mark where they light."

"There they go down-in line with that brushstake and that church over on the mainland," I called.

"Hold it!'" cried Walter, starting up again, and he swung the Ladybird towards the marsh-bank following my bearing. We shoved her nose on the bank and got the anchor out on the marsh. Then Walter and I crept on all fours over the grass a hundred yards apart, rising up cautiously now and then to look.

Suddenly Walter changed his plan and began a set of manœuvres that were to me inexplicable. First he stood up, in plain view of all the birds in the marsh; but when I essayed to do likewise he waved me down so energetically that he could not be disobeyed. Then he strolled unconcernedly back to the boat, but when I attempted to follow I got a furious signal to keep down. Then he and the Kid got into the duck-boat, and soon their heads began to move along just above the marsh, while I began to sense glimmering's of a game of strategy that should have been obvious to the in- 
telligence of a frog in the first place. Evidently there was some obstruction in the marsh, like a deep wide creek, and the birds were beyond it, so Walter had taken the duck-boat up the main channel to get on the other side of them and thus give us all a shot.

This plan went swiftly to completion. Soon the heads had reached a point directly opposite to me, a quarter of a mile away, and presently two humpy figures crept little by little across the marsh towards me. Nearer and nearer they came, in short creeping runs; suddenly the flock rose out of the marsh pond and Pank! went the Kid's 28, bringing one to earth. Then Walter arose and opened up like a tornado, his old scatter-gun dealing out swift death like a vast invisible flail that struck down bird after bird with every discharge. One cripple fled shrieking across the marsh, only to be overtaken by the same swift death as Walter's fourth report rang out.

The flock came directly down-wind in a bunch towards me. I squatted, a motionless hump in the marsh, as inert as the log I sat on. "Tsearp!" I whistled coaxingly. "Don't mind all that noise back there, friends, but come on in and settle here." Those fool birds actually cupped their wings and started to alight on my very hat! This 
would never do; they would get blown all to bits! Up, Guards, and at them! The flock wheeled sharply as my gun flew to shoulder, and at a neat 22 yards I opened up and dropped the first curlew stone dead across the creek. Then that old fullchoked, hard-hitting trap left on my double reached out and grabbed two more at about 40 yards, and my part of the programme was over. Walter's little game of strategy had been completely successful and we had seven curlew to show for his knowledge of their flight and habits.

By the time the spoils of conquest had been gathered and the Ladybird gotten under way again, the sun had set over the green-and-gold marshes. As we sped along we passed the shack again at, maybe, five hundred yards, but still a wide stretch of marsh and channel lay between us and it. Then a wide turn around a final point, and we were headed down a broad channel towards the open ocean, with the white lines of surf breaking on the bar at the lower end of it. The heavens were still filled with roseate splendour as we zigzagged our way through tortuous channels across the shoals to the shack; but down over the Pass was a sight to make any gunner's pulse beat the faster, for moving over it like a vast cloud was a queer shape of tiny black stipplings, constantly altering, now 
a long, attenuated serpentine figure, now bunched up like a pear, now with a lower lip hanging down, and then drawn up again as a curtain.

Walter far-sighted it, his sunburned face puckered up in a wuzzle. "Black-bellied plover going through the Pass," pronounced he with bated breath; "there must be at least a thousand in that flock!"

Presently we made the shack and unlocked its weather-beaten door. The incessant wind howled about its corners and wailed through every crack and crevice in its walls. There was a large marshpond behind the shack, with three great blue herons feeding in it-suitable fowl for our back-door yard! Walter and I busied ourselves about the little rusty stove, while the Kid stripped and went in for a swim in the clear salt water of the channel. For supper we had béccassine sautée à la Créole, which, in good United States, is golden plover and onions, steamed and basted in the frypan with a squeeze of lemon; weakfish steaks from that big one who got too argumentative with Betsey Jane; creamed potatoes; a bucket of tea; and a pailful of stewed apricots and prunes mixed. The Kid tucked away some three or four assorted plates of this sturdy grub and was then himself tucked away to bed, for he had had a busy day. 


\section{SHORE BIRD SHOOTING}

Walter and I lit our pipes, grabbed our surfrods and started along the strand for the beach, to fish the ocean on a flooding tide by moonlight. The surf was high, as often on this coast, but by walking along the beach a mile or so we at length found a hole that could be fished, and landed two kingfish, a blue, and a couple of flounders in about an hour's fishing. I was more interested in the stage setting, however; fascinating to me were the moonlight on the restless ocean, the ceaseless whistle and whine of the wind, the continuous roar and wash of the angry surf, the ghostly white dunes with their inky shadows in the moonbeams, the litter of wreckage on the lonely beach, and the flash and stare of the distant lighthouses, sole reminders that the world was still inhabited. It was a wild place, and it was good to feel oneself again a mere infinitesimal atom in the vast scheme of Nature's world. 


\section{CHAPTER IX}

\section{DUCK SHOOTING-ANTICIPATION}

As the wintry blasts of late November began to drive the ducks southward, The Boy and I abandoned the quail uplands for the salt marshes. Our first problem was what would be the best duck load for the Boy's 28-gauge. With a light twelve, such as a boy of fourteen or fifteen could shoot, the standard load for salt water ducks would be $11 / 4$ ounce No. 4's chilled, because it takes a heavy pellet to penetrate their thick coat of feathers. For fresh water ducks-mallards, teal, redheads and the like, fives are better because of the increased number of pellets in the shot pattern. But, for a 28 or a 20 , fours and fives would be out of the question, because their little loads of $7 / 8$ and $5 / 8$ ounces of shot, respectively, would contain so few pellets as to make it a very scattering shot pattern at the ranges ducks are shot at over the decoys25 to 35 yards. Now, an old duckshooting friend of mine has a boy known to fame as The Cub, and he shoots ducks with a 20 -gauge, picking them out 
of the air with the little gun as accurately as a man can with the twelve. Also, another great sportsman friend of mine, Frank Stick, the artist who does many of the Field and Stream covers, shoots a 20 by preference and he uses it for all feathered game from ducks to quail. Both of these 20-gauge shots use 6's for ducks and seldom make any cripples, and with this to guide us we chose 6's for the 28 , with some shells loaded with 7 's to fall back on in case the misses with the 6's got too heartrending.

The next thing to do was to fix on a date for our duck trip to Barnegat. It will not do to just pick out a hard and fast date suitable to business or school conditions, for a fair calm day is the worst possible one for ducks, and any such day in a fairweather spell will turn out a failure. The time to go is just after a big northeast storm that has torn plenty of food loose from the bottom, and stirred up the great rafts of ducks and made them break up into restless small groups flying from point to point. Such a storm will surely come late in November, and then is the time to break away from business, play hookey from school, and GO! for your really good duck weather only occurs but a few times in a season.

Standard trapshooting is of little value in hit- 
ting ducks-they do not fly away from you as do the clay pigeons, but your shots will all be jumping shots, circling, crossing, and overhead, flying right at you. As the Boy did not want to go down to Barnegat totally unprepared for ducks we set aside several afternoons in November for practice with the fixed and hand traps, imitating duck flight as seen from the blind as closely as possible. For this we did not use No. 6 shot as we would in duck shooting but rather No. 8's chilled because the clay pigeon is enough smaller than even a small duck like a teal or a ruddy duck as to require a correspondingly small size of shot and dense pattern. The commonest shot in duck shooting is when they jump up from the decoys, a hard one to hit for they go up like rockets and you must either hold three or four feet above them or else wait for the top of the rise and take them when they stop to circle away horizontally. With broadbill the jump is not over fifteen feet, and the shot is rather easy if you only keep cool and wait. A black duck or a mallard may climb seventy-five feet before he stops to fly away horizontally and if he is far out the only thing to do is to hold above him with fast rising gun and stop him on the jump.

To imitate these two shots I hid in a narrow ravine in an open field, giving the Boy the same open 


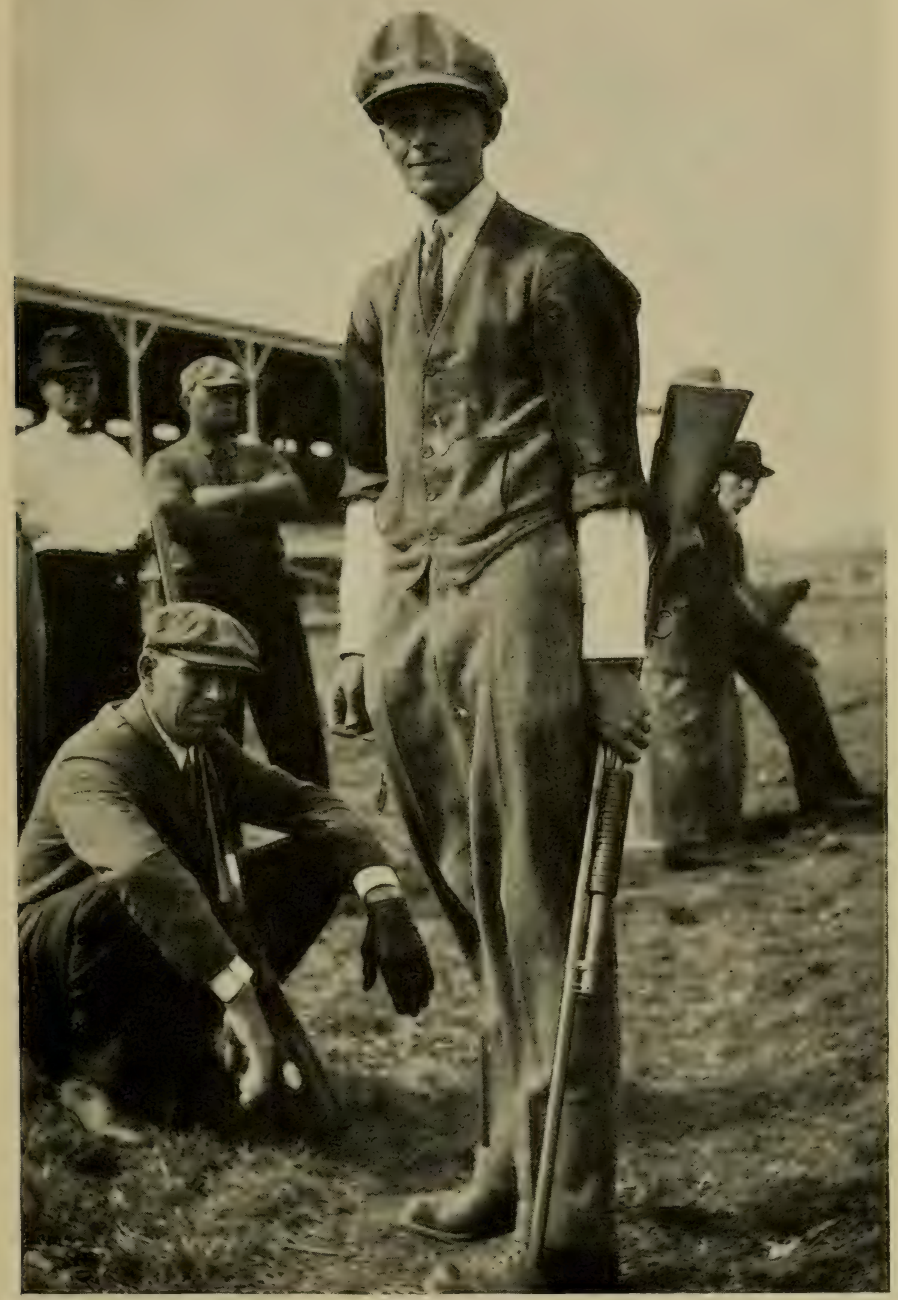

MAKING GOOD AT TRAPSHOOTING

Youthful winner of the preliminary handicap at the Grand American Trapshoot. 

skyline for his shots as in duck shooting, and I stationed him 20 yards away - the standard distance from the blind to the centre of the decoys-and then I threw up the blue rocks by hand to imitate the jump of a broadbill and shot them up with the hand trap on rather weak spring to imitate mallards. When he steadied down and began to smear them regularly at the top of the jump, I increased the tension on the spring and sent them up at considerable angle, making the Kid hold above them and break them on the rise.

Another common shot in duck shooting is when they circle about the decoys and you can tell by their actions that they do not intend to settle but will keep right on faster than ever, being suspicious of what they have already seen of the decoys. To get this shot we set the trap to shoot at right angles to the Kid's position, so that the birds would pass him at about 25 yards, the trap being set 30 yards to the right of his position. A lead of from four to six feet, with quick swinging gun enabled the Kid to hit these crossing birds after a little practice. Next I trained him on the hardest shot of all, incoming ducks which come right on over the decoys and over the blind, sprigtail doing this quite low and almost impossible to hit, and black ducks usually sheering high and passing 
overhead about 75 feet up. With sprig your best chance is to turn around and rake him astern, holding well below; with black ducks the overhead shot with gun on top of shoulder, fast swinging and leading him six to eight feet is the best bet.

In all this practice shooting for ducks the Boy was not allowed to stand up and take them easy, but was rather forced to lie down in an improvised blind and rise and shoot, sitting or kneeling, upon the whistled signal. How much difference this makes in one's ability to hit them must be tried to be appreciated, but that is the way your duck chances come, in point and battery shooting, and it is well to get used to handling the gun from all sorts of impossible positions before you go after the ducks themselves.

At last the great storm came, and after it a windy day when the sky was rained out, the grey clouds raced across the sky overhead, and one could almost smell ducks in the misty air. Early in the dark before dawn we boarded the Barnegat train, with our guns, shells, a dozen cork decoys in a gunny sack and a dozen folding paraffine paper decoys in the Kid's knapsack. We each wore rubber hip boots, wool sweaters, light drab canvas coats and trousers, and light drab canvas hats. A dark hat is fatal in the blinds, the ducks can spot 
it a mile and one cannot peep a head above the reeds to be on the lookout without being seen.

Soon we piled out of the train at Seaside Park and hired a duck boat. This is a low, broad craft with rounded deck, a small sail and a centreboard, and a railing around the cockpit in which to stick up a screen of sedge grass for concealment. The little sprit sail was set and we spun off before the wind, over the dark tumbling waters with no other guide but the low, black shores and the winking and flashing lights of the various Bay lighthouses. About two miles down the Bay on the eastern shore we chose a point and ran the boat on the beach. First mooring her, broadside to, in a little indentation, the Kid piled wet sea-grass all over her decks while I made a high fringe of sedge grass sticking up all around the cockpit. When we had finished by piling dry marsh hay inside and covering it with the tarpaulin we had a comfortable hide, completely merged into the shore line and seemingly an integral part of it.

Next we waded out with the decoys into the shallow water off the point. They should be about twenty yards from the hide to the inner ones of each group. The cork decoys were anchored in a group of twelve, each one attached to an anchor with six feet of fishline, the anchor being a 4 ounce 
pyramid sinker. These decoys represented broadbills or scaup ducks, and, as the black ducks will not associate with them, a second group was made of the dozen folding paper decoys which represented black ducks. This second group was placed a few yards to windward of the broadbill group. The folding decoys are made of paraffined paper, with a flat board float shoved inside. An adjustable weight serves to keep them on an even keel and also keeps them from tipping over from the wind. They are anchored the same as the cork decoys, and each one must have room enough to "visit" about as the wind drives it, to the end of its anchor line without colliding with the nearest neighbour. In a heavy wind and choppy sea these folding decoys are apt to upset and come to grief, so that one's main reliance should be on the cork decoys. This job finished, we climbed into the cockpit of the duckboat, lay down side by side, and were ready for the ducks. 


\section{CHAPTER X}

DUCK SHOOTING-REALISATION

Now the first grey streaks of dawn appeared in the east, and with fingers numb from handling the wet decoys we got ready the guns and lay down in the cockpit of the duckboat, which, as you will remember, in our last chapter had been converted into a point blind by covering with seaweed and putting up a screen of sedge grass through the railing around the outside of the cockpit.

"Now, Kid, load the 28 and put three shells on the cockpit coaming, sticking through the sedge and handy to get at."

I did the same with the shells of my double twelve-gauge Parker, instructing him also to lay the gun with its barrels poking through the sedge in position for instant use. So long as the barrels remain motionless the ducks seem to consider them as part of the scenery and mind them not at all.

"Now, you watch all the bay you can see to the north and northwest, while I will do the same with the south and southwest. Most of the birds will come directly in from out in the bay, circle upwind 
and make for the decoys-after which, goodness only knows what they will do!"

For some minutes we lay motionless, peering through the tops of the sedge screen around the cockpit. Then-"Mark, northwest, father!" came the Kid's low, tense whisper.

Over they came, over the grey waves; fifteen dark specks, flying low with fast-flapping wings, fast as bullets and heading directly for the decoys.

"Broadbills, son!" I exclaimed, laying a restraining hand on the Kid's shaking shoulder.

"Prrrh! Prrrh!-Get ready, Kid!"

We crouched down in the hay with finger on trigger while the flock circled upwind. Half a dozen dropped out and splashed down amid the decoys. The rest circled once again and started to fly away. Seeing this the six in the decoys jumped.

Bang!-Bang! Spank! went the ready guns, taking them at the top of the jump. "Reload for all you're worth, son!" I cried. "Never mind that cripple just now-take that fellow crossing!"

The bunch had exploded every which way at our fire, one bewildered duck turning completely around and flying across the stools to regain his comrades. Him I dropped on the Kid's miss.

"Three down, anyway-quick!-hit that cripple 
before he dives!" The Kid's 28 flashed to shoulder and his shot splattered the waves where the duck had been. "Gee, that was a hen redhead, Boy! Watch out for her bill, for that is all you will see when she comes up again."

We waded out to pick up the slain. "Good shooting, kidlet! You got that duck just as pretty at the top of his rise-Shoot!-there she comes!" Both guns roared together, spreading a veritable shower of shot where a bill stuck up out of the waters not twenty feet away. "Got her that time! That makes four; some clean-up! Hurry, now, back to the blind."

Half an hour passed without incident. We opened a thermos bottle and each took a nip of hot coffee to drive away the chills. "Mark west!" I yelled, hastily corking the bottle. "Down! Down! Keep down, Kid; they're flying high!"

A flock of five "Jakeys," as the black ducks are called by the baymen, flapped towards us, flying high, as is their wont. We lay flat as pancakes.

"Keb! Keb! Keb!" I called alluringly. But the old leader was wary. He stretched down his long, snaky neck inquiringly. Those wooden decoys didn't look good to him; suddenly he sheered up, put on a raft of power and they went directly over us, 25 yards high. 


\section{"Shoot! Quick, Kid!"}

Blam! spoke the twelve as the Kid wabbled and pottered about, trying to balance his gun on top of his shoulder. The old leader came down with a thud not more than ten feet from the boat. "Gee, Boy, but you were slower than molasses in January with that duck! Remember that they are going only about 110 miles an hour, and you haven't got all day to shoot in!',

'The Kid brought him in to the boat, a big duck, 22 inches long from bill to tail feather. We settled down again without a shot for some time, but the wait was full of thrills, for ducks in flights small and large were winging up and down the bay, all more or less out of range, but each near enough for us to dodge down flat and call our best.

Then, "Mark north, papa!"

A flock of broadbills was winging low over the waves, 'way to the north but headed to pass our decoys far out.

"I'll try and get them in, son," said I, grabbing" off my hat and swinging it quickly once or twice in a vertical semicircle above the sedge screen. Instantly they veered and swung into our stools. "They're wild and are not going to stop, Kid; get ready!-Now!", 


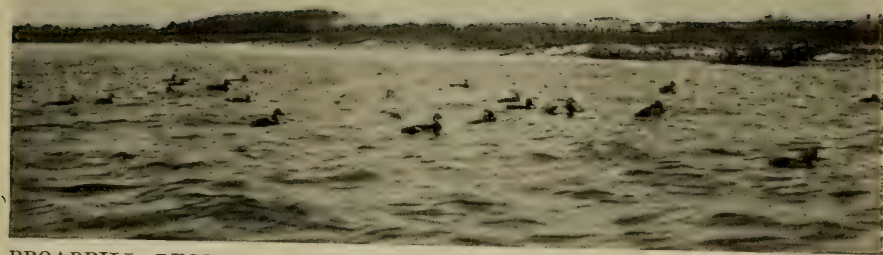

BROADBILL DECOYS ANCHORED OFF A POINT The distance is about 20 yards from the blind; proportion of females
to males, 3 to 2 .

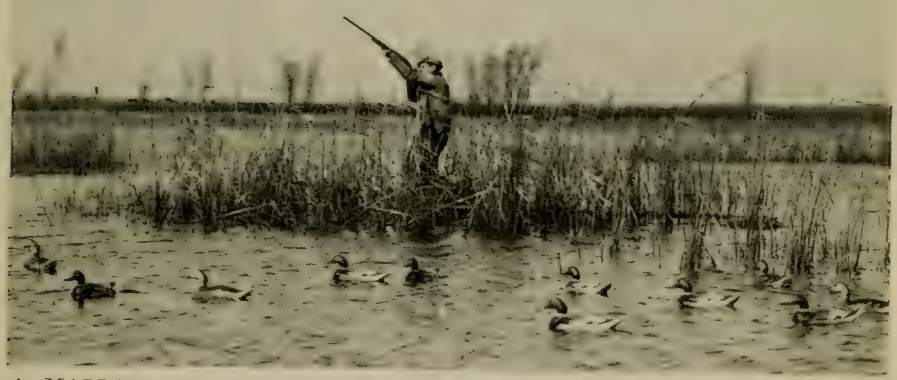

A MALLARD HIDE IN THE WILD RICE These decoys are too near the hide and too many drakes. The hide
on the point to the left would be better.

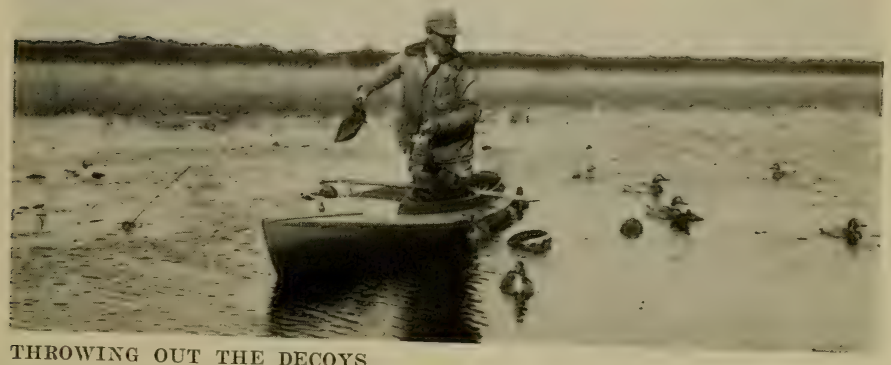

THROWING OUT THE DECOYS

Each one has a $6 \mathrm{oz}$. lead anchor and a few yards of strong twine so that they can visit about as the wind blows them. 
$-$ 
We both arose and gave them a greeting as they swung over the decoys. Two dropped, nice cross shots, both of them.

"Now I'll explain a bit," said I as we waded out to pick them up. "That hat stunt was to imitate a duck jumping off the water and alighting a yard or so further on. They often do that when visiting and feeding. One duck pecks another and he jumps and tumbles again a little further on. The flash of that hat above the sedge looked just like feeding ducks to them at the distance that flock was away. Without attracting their attention that way they would have never noticed our decoys at all. And I could tell by the way they sheered up when they circled that they weren't going to alight. Some day I'll teach you the difference between the Keb! Keb! Keb! of a scolding mallard hen and the Miamph! Miamph! of a duck with his mouth full of feed. Meanwhile, try your hand at this duck call. Put the wooden end of it in your mouth and close your hand over the metal end. The trick is to flap it open simultaneously with making a quack with the call. Only so can you get a convincing quack. Try it.', The Kid grabbed the duck call, and, after some ludicrous efforts, soon got quite expert with it, manipulating his hand simultaneously with the blow for loud quack- 
ing calls and covering it artistically for the low conversational duck talk that goes on while a flock is feeding. In the midst of which-

"Drop it!-Heavens, mark southwest! Down! Flat down!"

A great flock of jakeys were fluttering across the sky in a long silent V. Artfully we quacked, one blatant, squawking, scolding call, and then were silent, crouching down with ready guns. They circled high, cupped their wings and volplaned down. The air was full of ducks. Thirty dropped out and began visiting among our stools. The rest hovered, and duck after duck dropped down on the water. The Kid shivered with excitement-never was such a thrilling moment!

"Now, Boy, take it easy!', I admonished in a low tone. "You've only got one shot and had better get your eye on one particular bird and take him the instant he flashes up from the water. I'll get one on the rise and one of the top of the jump -if we have luck! They'll get onto those paper decoys in a moment!-Now!!"

We rose to our knees, and with a deafening roar of wings the great flock jumped for the sky. The 28 knocked one right off the water and crippled another, the twelve got two on the rise and stopped another dead at the top of the jump. Then a lot 


\section{DUCK SHOOTING}

of promiscuous firing into a maze of circling ducks and the flock was off and out of range.

"Gee, pop-what a day!" gasped the Kid, his eyes dancing with excitement.

"Pretty good, for Barnegat-or Great South Bay either-these times. But it's about over, son, for here comes the rain."

It came down in sheets. We ate lunch under the "tarp" and later decided it was to be an all-afternoon downpour.

"No use, Kid; no ducks paying any attention to decoys in this rain; it's time to up stools and go home."

So we took up the decoys, packed them, cleaned up the boat and set sail hilariously in the rain for Seaside Park, with six black ducks, seven broadbills and a redhead to show for the day's sport. Like all games where one follows the shotgun or rifle, it called for grit in enduring hardship, skill in woodcraft and the use of the gun, besides a host of minor accomplishments such as sailing a boat in a storm, canoeing, hitting the trail and portage, camp craft, cookery, and, above all, a sunny and gloom-proof character. 


\section{CHAPTER XI}

\section{A CHAPTER ON THE RIFLE}

WE are a nation of riflemen. Pessimists are inclined to shake their heads and put it "we were a nation of riflemen," but as a matter of fact there are a good many more riflemen in the country now than ever before. The United States Biological Survey puts the number of licensed hunters in this country at four and a half million in round numbers, and this takes no account of the great southern section of the country where the State license system has hardly yet come into existence. During the agitation for national defense Field and Stream made a canvass, covering all sections of the country, to learn how many and what arms the four and a half million licensed hunters carried, and it found that they owned one shotgun, one rifle and half a revolver per man. That accounts for the query, "where do the arms manufacturers dispose of the big game rifles that they sell at the rate of over a million a year?" Judging from what you see in the great cities, none of our citi- 


\section{A CHAPTER ON THE RIFLE 163}

zens know anything about a rifle; but go into the country, the farms and small towns which contain the vast bulk of our population, and you will find the rifle and proficiency in its use, as of old.

Most of our riflemen become experts when boys. We all begin with the accurate, hard-hitting air rifle, and usually at the age of ten to eleven years.

When I was a boy the "star" air rifle was the red "Chicago," a weapon with a brass tube and brass air chamber mounted in a red stock of hard wood. It had a powerful spring and it took all your strength to load. But it shot hard and accurately and was good for squirrels, rabbits, larks, high-holers and robins, all of which were in copious abundance in those days and formed the boys' game and meat. A pound of BB shot kept you in ammunition a long while, and enabled thousands of shots to be fired in practice at little cost. I wore out three of those rifles before graduating into the .22 powder rifle, and, together with all the rest of the tribe became a nail driver, that is, we could drive in a nail by hitting it on the head as far as we could see it. Such a mark as a grape or a dime at twenty-five feet was a cinch to us, we just couldn't miss it, and, for game, the red air rifles kept us always with plenty of meat in the stew. The city boys used to come out into the 
country armed with cheap, nickle-plated iron air rifles of no power and no accuracy, with a huge cast-iron front sight that could not be set or adjusted and so untrue to themselves that never twice would the rifle put its bullet in the same spot. At first we looked with awe and envy on those shiny guns, as appearing exactly like a "real", gun, but the first shooting match against them dispelled the illusion!

But, alas! for frail boy nature-the lure of that shiny weapon proved too much, in the gun store, to sell a "wooden" gun against it, and the nickle cheap-and-nastys drove the honest hard-hitting red gun out of the market, just as the white man has driven out the red. Then came a period when the air rifle fell into just disrepute; it became a dangerous plaything in the hands of the grasshopper-brained city boys, and soon all the big populous States legislated against it. We forest dwellers took to the .22 rifle and its heavier brother the .32-and paid the price for the city boys' foolishness, the while we mourned the lost red rifle. But, of late years a change has come. A new rifle is on the market, for about $\$ 3$, three times as much as the red rifle cost, but it is as hard shooting and accurate as the old red gun. Besides, it is a fast repeater, with a sliding wooden 


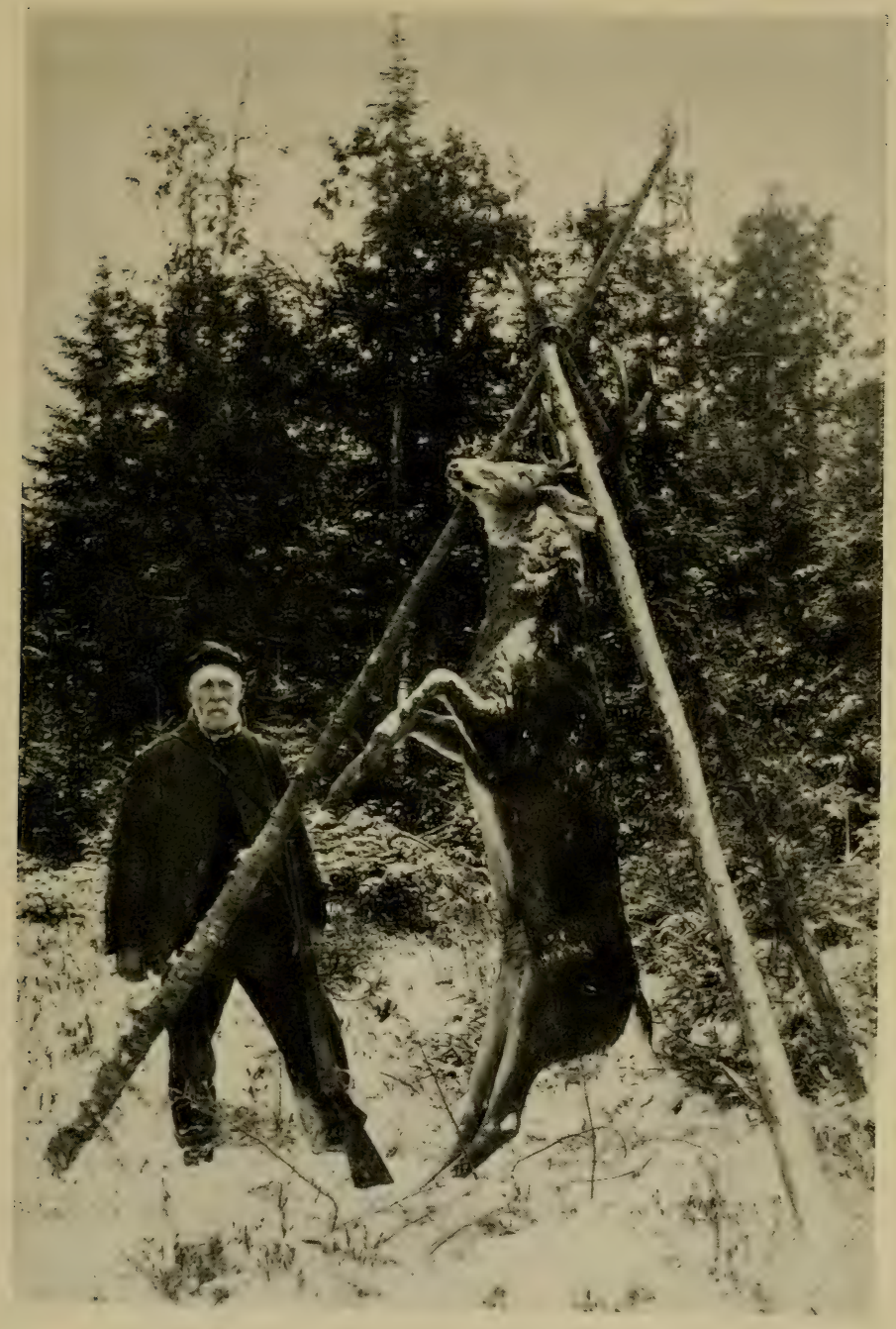

THE MOST POPLLAR BIG-GAME, THE WHITH-TAIIF DIER

With a tripod you can hang up your deer alone and unaided, moving
one foot of the pole at a time. 



\section{A CHAPTER ON THE RIFLE 165}

grip under the barrel just like a Winchester or Remington pump; it holds about fifty shot in the magazine, has a take-down screw so it can be taken apart and packed, and all its metal parts are dull blue steel. A fine weapon for $\$ 3$-how we boys would have jumped at it in our time! This gun I can recommend to any boy between the ages of ten and twelve years-pass over the cheap dollar rifle which cannot hit anything and save up for this one. If you can afford a little more, the steel air rifles that shoot heavy darts and slugs are almost as powerful as a .22 and are entirely accurate. With a few darts almost unlimited practice can be had very cheaply, for you simply pull them out of the board target and use them over again. In the woods the slugs will be effective on anything you can hit.

In all woods hunting with the air rifle you are in the Indian's class in stalking your game. Get up close by superior woodcraft, silence, and stealth before firing the fatal shot. All song birds, larks, flickers and small shore birds are now protected by the Federal Government, so your list of shootable game is much reduced; but a new form of hunting, pest killing, has grown up. Try your skill on the wiley crow, jays, hawks and other vermin and see how very much woodcraft and 
hunter's knowledge you will have to display to win out. Squirrels, rabbits, large shore birds, larks in the south, wild doves-these are about all the game the laws still leave to the boy hunter with his air rifle, so its principal use nowadays is preliminary practice for the .22 and the shotgun.

In learning to shoot, discard anything you may have read about military rifle shooting systems. There is no "prone" nor "offhand" nor any other particular position in game shooting; most often it is standing up and shooting from the shoulder. A quick accurate aim is the ideal to work to. The military systems make for extreme accuracy, but, alas! they take no account whatever of time, and your wild game seldom or never stands still. The fleeting moment when he stops all motion is your one chance to paste him, and a quick accurate aim is the only thing. Few realise how lightning-quick the eye is. The instant you see the game over the sights is the time to fire. A second later the muscles will have moved the sights away and another aim must be had. The thing, then, to train is the trigger finger and eye to work together instantly on orders from the brain. The eye tells the brain that the sights are lined up on the game and at that instant the trigger finger must release. That's all there is to it, 


\section{A CHAPTER ON THE RIFLE 167}

but there is a long road between the beginner and the attainment of that ideal. As a boy I reached it in about four months of steady rifle practice, firing maybe fifty thousand rounds of BB's out of the red air rifle.

The first thing to train is the muscles that hold the gun in position. They get tired and tremble just like any other muscles and must be hardened through much practice. A cheap way to do it is to have a tack head somewhere in your room and give at least fifteen minutes every day to aiming at it and firing the empty gun. With some rifles this cannot be done without hurting the gun, but if you keep a few empty shells and extract them each time, turning them to a new firing position at each shot the wear on the firing pin will be small. This silent practice is almost as beneficial in training the eye, the trigger finger, and the muscles of arm and shoulder, legs and body as actual firing at a target, only there is no "answer" as to where your shot hit.

Supplement it with frequent practice at standard paper targets until your scores tell you you have acquired steadiness. In all this work take some time to each aim; it will not help your accuracy much, but it does help harden the muscles which do the work of holding. The standard tar- 
gets can be bought very cheaply from any sporting goods store. Begin with the inch bullseye at 25 yards, the paper targets costing about a nickle for two dozen. Then the two-inch at 50 yards, followed by the four-inch at 100 and finally the 8inch at 200 yards. Theoretically all these targets are equally easy to hit with the same holding, for they are all in direct proportion to the distance. Actually they are increasingly difficult owing to difficulties in windage, seeing clearly, mirage, etc. The limit of range for the air rifle is around 25 yards; start the target at 15 yards and work back to 25. Never try too long a range at the start, it is a pure waste of ammunition. The limit of the .22 rifle is 100 yards for accurate work using the long rifle cartridge. Here again start with easy ranges, fifteen to twenty yards, using the inch bullseye target and gradually moving it back to twenty-five yards. From there work back to the fifty-yard range with the 2-inch bull and then to the hundred-yard which is about as far as one needs to use the .22. A boy can become very accurate at even this range. Only a few days before this was written we were all shooting at the hundred-yard range, my own 11-year-old boy using his Stevens "Favourite", and long rifle cartridges. In his first round the Kid ran up $39 \times 50$ against my 


\section{A CHAPTER ON THE RIFLE 169}

36 and was so chesty about it that I challenged him right off, as befitted the head of the family. So we went to it in earnest, and his next string showed a total of $44 \times 50$. This meant that all his shots were in that blessed four-inch bullseye except a couple, for we were shooting at a target that penalizes you one point for every inch or fraction away from the edge of the bull. This would never do! so, pulling myself together, I went after him red-headed and rolled up a $47 \times 50$, which means that they were about all in the bull, only three points out of fifty penalization.

But target practice is a bad thing except as a record to assist you in drawing closer and closer into the bull. You get too easily satisfied with shots that nearly hit the bull, counting up almost as high on your score as the bull itself, whereas in real game shooting "a miss is as good as a mile." In other words, if you cannot hit the bull, all the close misses in the world will not help. So, as soon as your scores show a reasonable accuracy, drop the target and begin on marks, glass bottles, pebbles, tin cans, clay pigeons, anything that can be hit and made to bounce with a bullet. These ought to be out in the woods or on a fence post in an empty field so as to get you used to sighting conditions in the woods. The greyer and 
more indistinct the object the better, for we now come into a new phase of rifle shooting-sighting. Formerly we saw the bull plainly, black on white paper, no easier thing for the eyes could be devised, but now, in the woods, sights and game or object are all one blur of grey colour, and we cannot see the front sight in the notch clearly nor the game distinctly. And another thing now comes up-range. Any one can hit a vertical mark, like a string or an upright withe, but to hit the same mark held horizontally takes good holding.

So you have two new things to learn, how much of your front sight to see to get the right range, and how to hold so as to see at all. The front sight wants a white or bright point on it. For an ordinary leaf sight this is easiest obtained by filling a forty-five degree flat on the corner of the sight facing towards the rear sight. With this to reflect the sky light back into the shooter's eye, not only is the front sight clearly distinguished but it can be seen much later in the evening and earlier in the morning than any other front sight, a point of importance to hunters. Holding this on a grey or brown object the front sight appears a light shaft sticking up through the rear notch. The latter must be black, with either a flat bar and white line or a distinct $U$, so that the front sight 


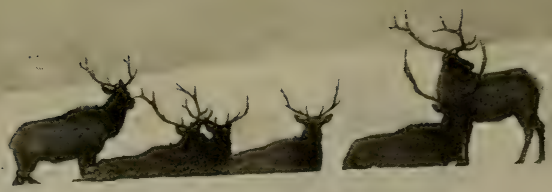

SOME FINE WYOMING ELK

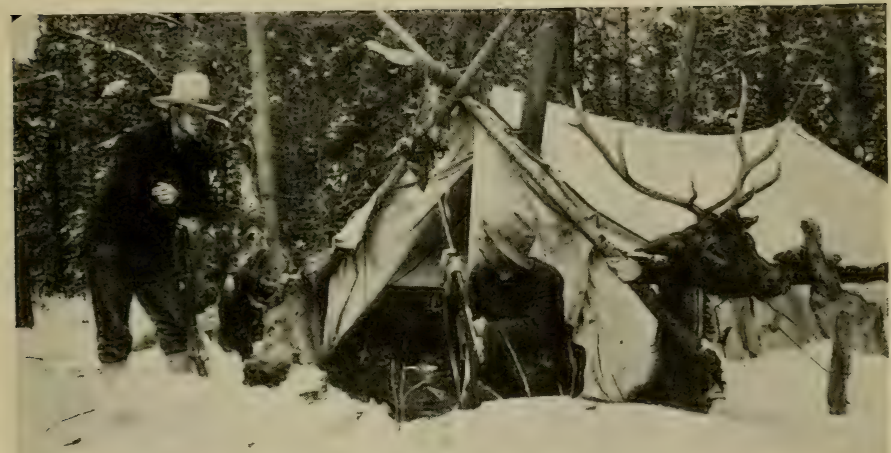

THE AUTHOR AND HIS COWBOY CHUM IX CAMP IN MONTANA

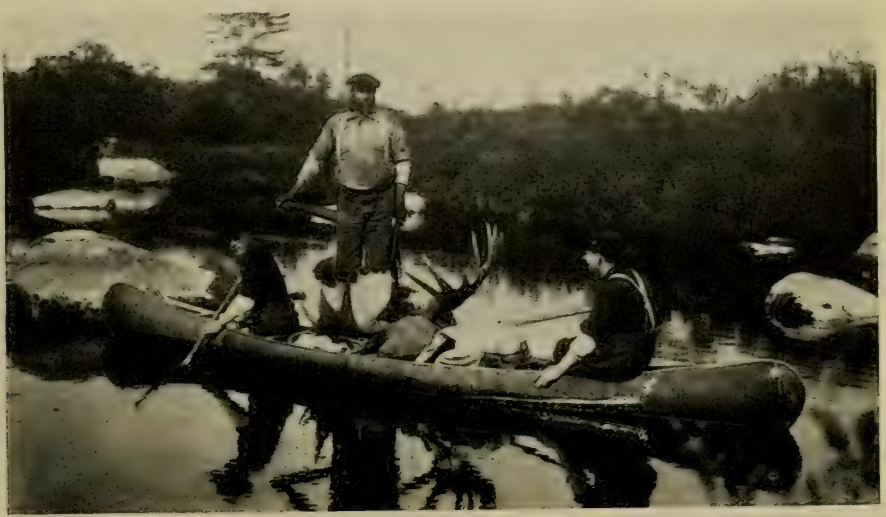

BRINGING OUT YOUR MOOSE HEAD

Note birch bark canoe and birch calling horn. 



\section{A CHAPTER ON THE RIFLE 171}

can be seen clearly in it without blurring. When sighting game, look at the game and align the sights at one glance, thereafter keeping them in mind only so far as to know that they have not gotten out of line while you concentrate your attention on the game. How much of your front sight should be cut off by the rear $U$ : at different ranges can only be learned with practice with your particular rifle at various marks until you get to be good at estimating distances in the woods, a deceptive thing at first. In general, set your sight so that the top of the front sight comes on a level with the top of the $U$ when you are due to land fair and square on a horizontal mark at fifty yards; above and below that distance draw coarse or fine as your experience tells you. Do not fool with adjustable sights and elevations. Leave those matters to the military, who have all the time in the world; when you see your game you have no time to monkey with sight adjustment, estimate your range, draw fine or coarse, and chuck it to him!

So far, so good, if the beast would only stand still! But as a rule he doesn't, or at best for a very brief period. Your previous training on quick accurate firing has prepared you for the brief stop period, but often he sees you first, and 
your first glimpse of him is a grey or brown streak going as fast as four legs can take him! Are you to sit and gape at him or wait helplessly hoping he will stop? Not at all, you just lead that running animal as you would a bird in wing shooting. The rifle sights are held rigidly in line and the rifle swung on the game and ahead of it, swinging and following through just as in wing shooting. The only difference is that, as you have but one bullet, a much greater care must be exercised in holding the sights true when the rifle is being swung.

The best practice for this sort of shooting is to make a pendulum deer, and it is great fun to shoot at him, too. Get a long flat strip of white pine moulding from the mill-fourteen feet is none too much. One of you climb a tree with a saw and cut off a branch about eighteen feet up to leave a short stub from which the pendulum can be swung free. Another boy will be cutting out of cardboard a miniature deer about eighteen inches long from hind foot to nose. Tack him to the bottom of your strip of pine and brace him by adding a flat strip like a kite brace so he will not curve or crumple when the wind strikes him. Tie on behind the deer a weight of about two pounds, an old flat file will do, and he is ready to hang. The boy up the 


\section{A CHAPTER ON THE RIFLE 173}

tree now drives a wire nail through the upper end of the pine strip pendulum and into the stub, so that the deer is free to swing in great ares of about eighteen feet. He will be going something like thirty feet a second in mid-swing, and you make a rule that he is to be taken in mid-swing or not at all. Shots at him when he is slowing up at the ends of his swing do not count. You can have a fine time with that deer, using the repeating air rifle described above at about 25 yards. The boy with the rifle takes his stand at that distance perpendicular to the line of swing, while the other boy raises the deer up to the end of his swing. At the word "Go!" he releases the deer which swoops down and up the other side of his swing. The boy must fire as the deer passes in mid-swing. If he fails to fire it counts a miss. No firing allowed on the back swing, nor after the deer has made his fourth swing, for by that time he is only going about ten feet to the swing, and therefore much slower. It's a great game, and the rifle can be reloaded plenty quick enough for a shot at each swing. The best I ever could do with it was four hits out of five, and the Kid does two to three hits in each string of five. You have to lead him about two feet ahead with fast swinging rifle. As the speed of the air rifle bullet is about the same 
over 25 yards as the .22 long rifle is over 100 , you would have to lead the real deer about the same at the latter range.

In general, the principles of woods riflemanship may be summed up as follows: In aiming never come down from above, as that blots out a clear view of your game, always come up from below. Get the sights in line as the rifle rises, draw the right amount of front sight as you come up into your game, and, when the front bead or sight top is in behind the shoulder (or ahead of the shoulder for running game), release the trigger instantly. Never jerk or flinch when pulling the trigger; always release with both eyes open, watching the game all the time. By noting where your sights were when the rifle went off you can "call your shot" as military men say. It is a good habit to get into and always helps in improving your shooting. Take your time on running game-he can't get out of sight just yet; watch for a favorable opening through the forest and catch him there. Hold low, and shoot when he is coming down in his bound. The commonest mistake in big game and furred game rifle shooting is over-shooting. In his anxiety to be sure to see the sights and the animal plainly, the rifleman sees altogether too much front sight, with the result that he throws 


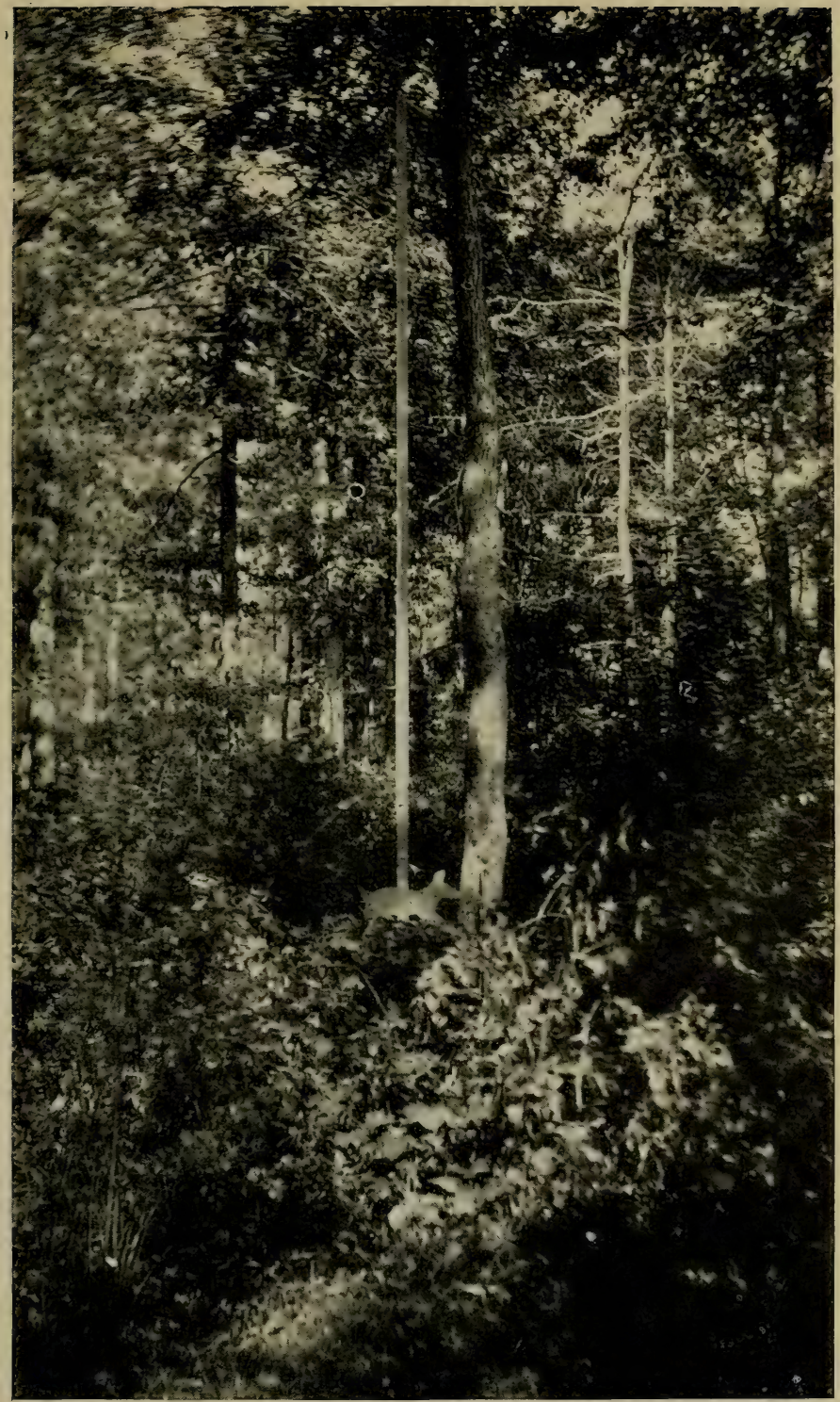





\section{A CHAPTER ON THE RIFLE 175}

his bullet clear over the animal's back. All animals are much harder to hit than they look; any one who cannot get in the target four ring at two hundred yards every time is not a good enough shot for big game, for your total circle of hitting area does not exceed 24 inches diameter. It would seem impossible to miss a bear as big as a cow at a hundred yards, but the thing is done with surprising regularity by the best of shots; they get excited and hold a bit too coarse and overshoot, and all the rest of the bear doesn't count! Do not use a rifle sling in game shooting; a strap just long enough to carry it over your shoulder or back is fine, and this strap should be adjusted so that when your left elbow is crooked into it the rifle is rigidly to shoulder. So aimed it is a great help to steadying, particularly in a wind, and you can take aim that way nearly as quickly as with no strap at all. Have a canvas case, never a leather case, for your rifle; the leather case easily gets watersoaked on the trail and takes forever to dry out again.

And now, what rifle shall we get for a boy of ten to fourteen years' age? I should advise: ten to twelve, the air rifle, a good one, not a tin toy gun; and twelve to fourteen, the .22 rifle, either single or repeater. Do not get this too cheap- 
the steel in the barrel is what counts and it cannot be had for nothing. A cheap rifle costing around $\$ 2$ to $\$ 3$ will have such soft, poor steel in the barrel that it quickly rusts inside, and the smokeless cartridges simply rot it like paper. In a few months the cheap rifle that shot so well at the start (having been forgotten maybe as to cleaning, once or twice) is astonishingly inaccurate-will miss a four-inch clay saucer at fifteen feet every time, if you will believe me-and no amount of cleaning will restore its former accuracy. You might as well throw it away, for an inaccurate rifle is no rifle at all. " "To thine own self be true," as Shakespeare says, is just as applicable to rifles as to boys. But, around $\$ 4$, we begin to get rifles that are made of good steel and will shoot true, year in and year out, even if somewhat neglected in cleaning. The Winchester bolt .22, the Stevens Favourite, the Remington single shot takedown, and the Savage, Jr., are all fine little single shot weapons, taking .22 shorts, longs and long rifles, built to last and to shoot. They all take down, that is, come apart at the breach so as to be easily packed, and all weigh about $41 / 2$ pounds, and cost from $\$ 3.50$ to $\$ 5$. Then, in repeaters, we have the Savage bolt action at $\$ 6$ and the Remington, Marlin and Winchester slide actions all costing around 


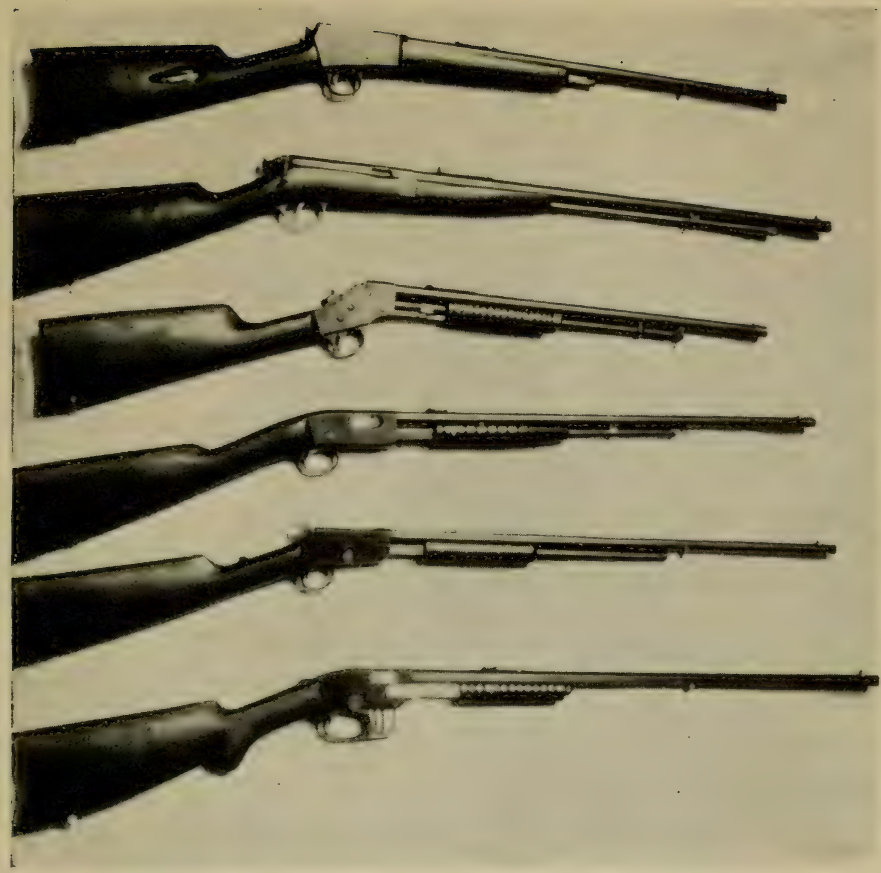

SOME .22 REPEATING RIFLES

Top to bottom: Winchester Auto, Hopkins and Allen, Stevens, Remington, Marlin and Savage.

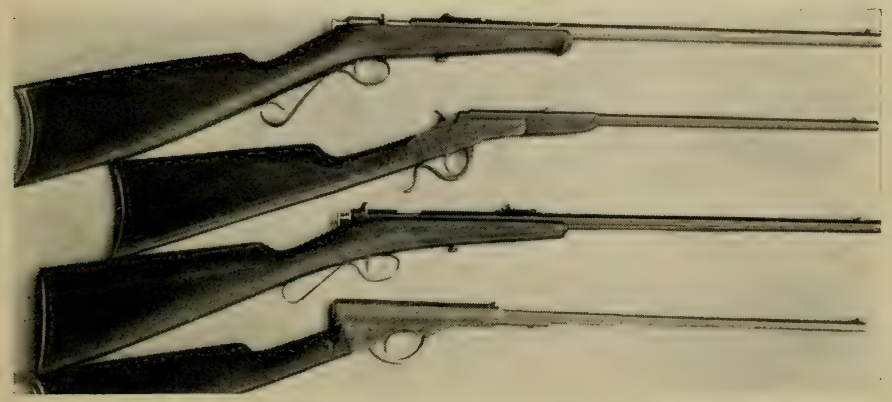

SOME .22 SINGLE SHOTS

Top to bottom: Winchester bolt, Stevens-Maynard, Savage bolt re. peater, Quackenbush .21 cal. air rifle. 



\section{A CHAPTER ON THE RIFLE 177 .}

$\$ 11$, and as good and accurate small rifles as are made. So equipped, the boy is armed for a trap line in winter, when he can play with snowshoes and toboggan as much as he likes; can shoot frogs and snakes in the spring; practice in the summer, and get out into the woods in the fall after game when the season opens up. Even in summer he can make a good penny shooting woodchucks, that pest of the farmer's field. I have one boy friend who camps each year in August in a good woodchuck country and all the farmers welcome him for they know he is a fine shot and will "lay." for Mr. Woodchuck until he gets him.

Remember that all these rifles, in all their cartridges, are deadly to human life, so don't go monkeying with them, but chastise any boy who gets careless or foolish with such a weapon. The long rifle cartridge will kill wolf, deer and small bear, and has done so time out of mind, so look where you shoot before you turn one of those express trains loose!

I do not believe that boys under sixteen years old have the endurance, courage and experience necessary to endure the hardihoods of the big game trail. It is a man's sport, and a real man at that, no weaklings or quitters need apply! But, around sixteen years the youth longs to kill his 
first buck, and he wants to graduate from the .22 into something heavier. One of the best allaround rifles is the .32-20 Winchester or Marlin, which takes three cartridges, the $.32-20 \mathrm{H} . \mathrm{V}$. for the minor big game such as deer and black bear; the .32-20 black powder for large furred game, such as foxes, woodchucks, raccoons, etc.; and the $.32 \mathrm{~S}$. \& W. shorts for all small game, like rabbits and squirrels. The rifle shoots all three cartridges without readjustment, and passes the first two through its magazine action. An excellent weapon for a youth on his first war-trail. Then the two new Savage weapons, the .22 H.P. and the $.250-3000$ should be considered. They are not good for even thinly settled country, but for the wilderness trail are fine and light and very powerful on deer, caribou, wolf, bear, etc. For moose and elk the .33 Winchester or Marlin is a very good youth's choice. It is light, $7 \frac{1}{2}$ pounds, powerful enough for moose or elk, has excellent sights, is inexpensive, and is much used by the North Woods guides and voyageurs. Probably the most popular deer rifle to-day is the $.30-30$, made by nearly all the arms manufacturers, a light, quickhandling little weapon, about twice as powerful as the .32-20. For small game all these rifles except the .33 have what is called an auxiliary cartridge, 


\section{A CHAPTER ON THE RIFLE 179}

a steel shell of the same shape as the bulged body of the regular powder cartridge, and recessed to take some such low-power cartridge as the .32 short. Such are somewhat of a nuisance to handle on the trail, but many a shot at grouse or snowshoe hare is presented while hunting big game, and with a nearly noiseless cartridge like the .32 S. \& W., much meat for the pot can be shot, saving the bacon until a kill at big game is made. But, if you take one of these, be sure to take along an extractor for it, or else you may have one break off in the rifle chamber, putting your rifle out of commission for the rest of the trip, for such a shell is hard to get out except with the extractor expressly made for this emergency.

Cleaning the rifle in all calibres is the most important duty you owe it. The.22 suffers most from dirt and neglect, and comes back at you by shooting abominably. Buy a bottle of nitro-solvent oil and a cleaning rod, and you will be insured against barrel troubles from the modern acid smokeless powders. Clean your rifle like a baby. You may laugh at the expression "trusty rifle," so overworked by cheap novelists, but you will not after your first big game trail. Your livelihood, and your life, many times, will hang on the trustiness of that same rifle, and a neglected rifle is not trustworthy. 
A final word, in these gunpowdery chapters - to the mother of the boy. The Indian placed Courage at the top of all manly virtues. Man is not naturally courageous, but grows more so the more his self reliance is called upon. No hesitating, vaccilating, timid boy or man ever gets far in this world. Sooner or later, and generally sooner, he is called to account for the sin of cowardice. There is no escaping it. The slings and arrows of outrageous fate seek him out, and unless he takes arms against his sea of troubles and ends them they will overwhelm him. To ask or expect a boy, grown to manhood with all his courageous faculties atrophied, to cope with life's battles like a brave knight of old, is like asking a horse to work without oats. Feed him courage as you would heavenly manna. Send him to the school of courage; yes-games are all right so far as they go, but they are not life, they are but games, and can be called off or stopped any time. But the great outdoors is not a game in that sense. The boy gets for the first time the experience of what it means to go on to the end. There's no backing out, no stopping that game! it's win or lose, come through master, as a man ought, or come through beaten by the great and relentless natural conditions that know no pity, take back and forgive nothing, pun- 


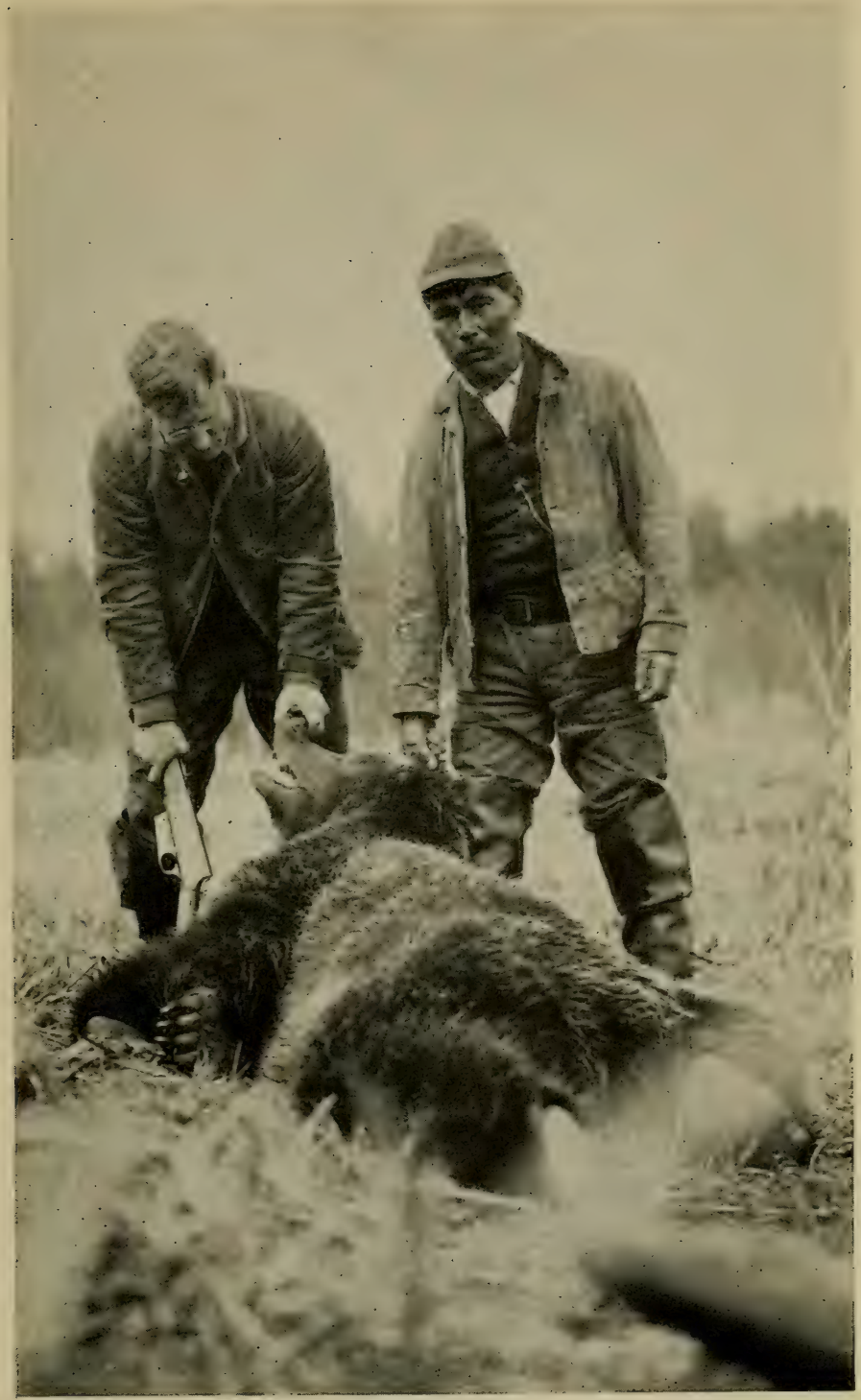

THE KING OF AMERICAN PREDATORY GAME

The great Alaska Brown Bear; his track is 18 inches long. 



\section{A CHAPTER ON THE RIFLE 181}

ish every fault to the limit. That is the true school of courage; those who have been on the trail can tell you how their courage is exercised constantly until it becomes second nature.

Woman shrinks at the idea of her boy taking animal life; of running dangers of upset, exposure, falls and tumbles, insects, snakes, and being shot in the woods for a deer; but life is just these things on a larger scale, and if your boy is to win out he must have courage and lots of it, so as not to quail when deadly sickness attacks his children, not to flinch when men threaten his livelihood and bully him of his rights, not to back down when something important must be decided. No mere game can prepare him for these things as can the great school of the woods; therefore, be wise, and see that he knows how to swim, to ride and shoot, to sail a boat, take care of himself in the open, catch game fish, do all those things that our wild ancestors did, as not only a preparation for the vicissitudes of life but as a recreation and relaxation to him in later manhood, for there is no vacation equal to the one afforded by the great woods. Let your boy learn the technique of it, and, no matter what he was when he started, I'll warrant he will be pretty nearly a man when he gets through! 

PART THREE: CAMPING FOR BOYS 



\title{
PART THREE: CAMPING FOR BOYS
}

\author{
CHAPTER I \\ BOY CAMPS OF LONG AGO
}

ALL boys like camping out. The utter freedom of it, the thrill of having all the world of nature to draw on for camp construction materials, of depending on one's own skill for comfort and sustenance, of having new country to see and explore, new birds, animals and insects to see, of sleeping out at night in the woods, by lake or bay shoreGee whizz! don't it come as near being perfection as any fun you ever had!

I well remember my first camp. I was twelve years old, and I and my particular chum had been the leading spirits in a great camping expedition to a wild shore three miles across the bay where shore birds were plentiful, clams and fish to be had in unlimited quantities, all the swimming you wanted, no clothing but a pair of bathing tights required, in a word, Freedom with a big F! Well, on the hour appointed two great thunder squalls 
arrived simultaneously out of the northwest and southwest with rain in bucketfuls. No one showed up but Chum and myself. 'Did we bemoan our luck and give up the camp? Not we! Not by a jugful! On went our bathing trunks, in went the duffle into our two sailing batteaux, up went the jibs, there being too much wind for our mainsails, and off we started through the roaring storm and were soon lost to view in the mist and fog.

We two boys, singing with glee in a pouring rain, ripping down to the South Shore under jib alone, all the goods and provisions under tarpaulinsthat was the way our first camp started. That night Eber, my chum, sailed back after the quitters, leaving me all alone on a stormy shore, having landed most of our provisions. Another heavy sea was getting up, night was coming on and the world looked rather lonely and inhospitable for a twelve-year-old kid. But I topped up the main boom, cast loose the foot of the mainsail and bent it around the cockpit coaming for a tent, pulled up my grating and laid it on the oars to form a long bunk comprising stern sheets, grating and middle thwart, and-lit my lantern. Instantly that cabin became a cosy little home with the rain pattering softly on the mainsail outside. The boat cushions made a comfortable bed, the 


\section{BOY CAMPS OF LONG AGO 187}

lantern lit up the interior, I tidied up the boat and let her pitch and rock to the storm outside. Gee, it was cosy and comfortable!

I read a book until nearly eleven o'clock when the storm blew out and a black stillness like a great mirror spread over the bay, streaked with the long lanes of light coming from the electrics on shore three miles across the bay, and the red path of light that came from the lighthouse. After a time, came a faint screech across the water; then more diabolical yells, sounds of people being murdered and falling down wells, all the fiendish noises that the human throat can invent. It was the Crowd, coming down in Eber's boat and the big sharpie. They rammed me amidships, full tilt when they finally arrived, nearly shaking the mainmast out of her, and I went ashore about twelve o'clock midnight to help them make camp. Such duffle! Three boatloads of it at least! In an hour everything was shipshape and they turned in. So did the mosquitoes. I went out to my boat to get some sleep but the rest, with no mosquito blind, were soon routed out of that tent, and the last I saw of them was a capering crowd of boys chasing each other about the beach in the moonlight at two in the morning. Unfortunately my boat was not out of range of rocks from shore, so 
that every now and then a bombardment would come aboard.

Finally I got off to sleep and awoke to find the boat aground on miles of sand flats and snipe wading about all along the shore. The rest had already got after them, and, as for me, I did not even take time to dress but in bare feet and shirt tail I set out with gun and cartridge bag as accoutrements and in an hour that bag was full of snipe and empty of cartridges, and my feet were cut to ribbons with oyster shells sticking up like knifeblades through the sand. Well, we had a week of royal sport over at that shore. We all slept out in the boats, at last, to get away from the mosquitoes, and the first boat awake would promptly ram the others. We treaded hardshell clams, each boy walking along the sandy bottom in water up to his shoulders, towing a box into which the clams were put after diving for them; we had some wonderful clambakes in our beach fires; we caught all the fish we could eat by the mere act of anchoring a mile off shore and baiting our hooks with a clam comb; we shot all the shore birds we needed for fresh meat; and we only came home when starved out by the absolute lack of potatoes and bread.

When I got home I could not sleep in a house at 
all; the walls and room seemed too stuffy for words. We had learnt a lot from that camp, principally that all our duffle was too heavy and bulky; but the fact did not press home so much until our next camp which was out in the forests in late September of that same year. Eber and I started out alone, as before, but this time we did not attempt to take the other fellows' duffle; our own was more than plenty to stagger under. We brought it out four miles from town in a borrowed cart, and, when we had driven the horse as far in the old lumber roads as he would go, we packed the rest in to the camp site.

Never will I forget that first woods camp. We jumped and capered and tore through the woods in sheer exuberance of spirits at being free once more. One week more and school would beginlet's make the most of it! We both went upstream for maybe half a mile before turning to report on a suitable camp site; and when we met again and described our selection it turned out that we both had picked the same site! It was a low knoll halfway down the ravine embankment with the brook at the bottom and a good drainage every way from the tent site. Followed a strenuous half hour of packing in the tons of stuff, and in an hour more 
the tent was pitched. This tent was one of the old Nessmuk shanty tents which I made on my mother's sewing machine of American drilling. It had too flat a roof so that bags would form in it with rain or snow and cause leaks, and it required several hours' work to make the frame for it. However, it permitted a bright open camp fire in front whose cheerful rays would penetrate to the farthest recesses of the tent and it was the very first advance on the old wall tent with its chilly interior and bulky paraphernalia, and to us it was the acme of camp comfort. We hustled the frame along, but, before we got half through, up came a howling thunderstorm drenching us to the skin and wetting down everything inside the tent unless we got it quickly into the grub box which was put in the only spot where there was no leak.

Then the sun came out and we took off all our clothes and enjoyed the naked freedom of the Red Man. Blankets were dried, grub started, night wood piles cut and a Nessmuk fire built in front of the tent. To make this we drove in two slanting stakes, piled up five six-inch logs four feet long one above the other against the back stakes, and put down two short logs for andirons and a forestick across their front ends to form a sort of boundary to the fire. A pyramid of sticks, chips, 


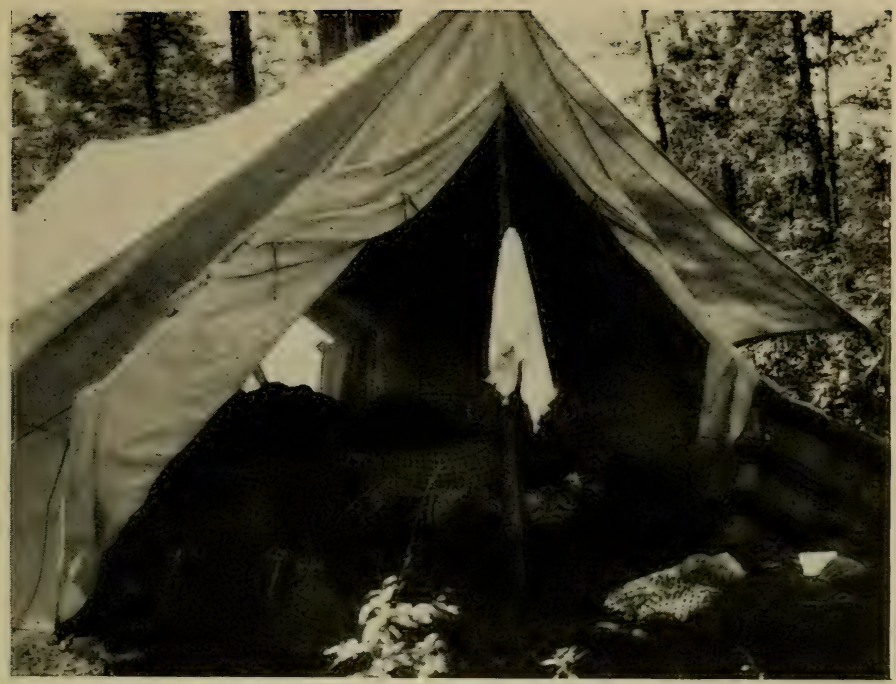

THE OLD-FASHIONED HEAVY WALL TENT. WITH FLY

Made of $10 \mathrm{oz}$. duck and weighing about 75 lbs. Note piles of duffle and heavy shoddy, blankets.

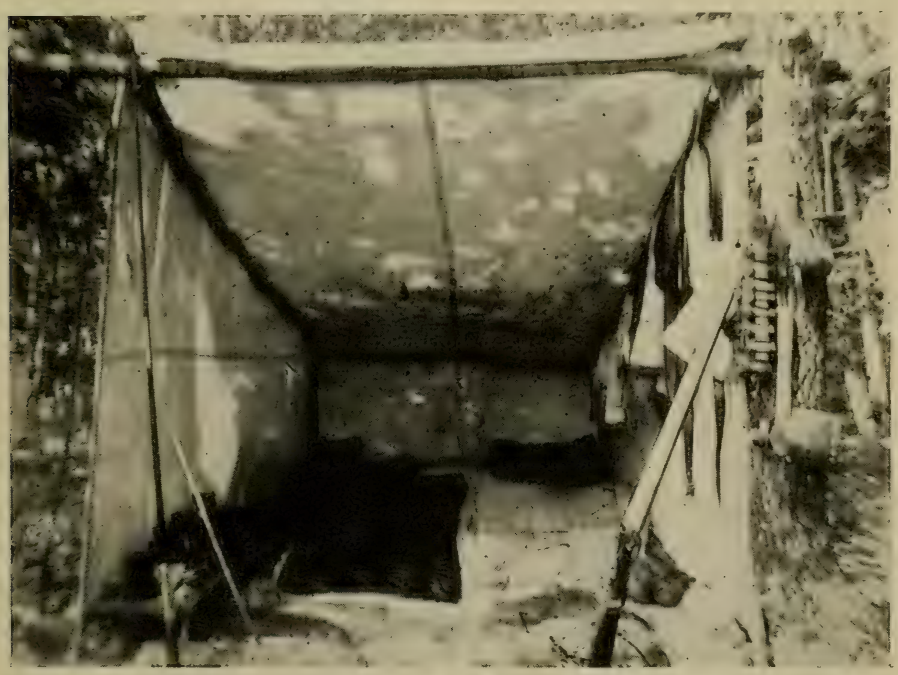

THE AUTHOR'S TENT HOME-MADE WHEN HE WAS A BOY OF TWELVE YEARS

This negative is nearly thirty years old. The gun is now used by the author's son and the tent is still in existence. One of the first for light camps, the tent slept three and weighed ten pounds. 



\section{BOY CAMPS OF LONG AGO 191}

etc., was piled in front of the backlogs and the fire was ready for dusk to come.

The cook fire was built of two parallel logs raised up on two short ones and staked fast, and over it went a dingle stick to hang pails on. Presently our first meal of fried ham, boiled spuds, bread and coffee was ready and we sat down to eat. Our cooks were fairly proficient, that is Eber and I were, for we were all there was of the camp so far, but in the middle of the meal we heard a grouse drumming out in the forest and immediately grub was forgotten and two eager hunters vanished into the woods.

Followed a long period of silence, and then suddenly there was a muffled roar of wings and the boom of Eber's gun. The noise started off a grey squirrel, far up in the tops of the great oaks over my head. He had been watching me motionless while I was stalking the grouse, but his move was fatal for he drew a quick bead and a hatful of sixes and tumbled to earth. Then, as silently as before, except for two triumphant war whoops denoting a successful kill, we returned to the meal. The grouse and squirrel were hung up with an emphatic "Ugh!" of approval on both sides and the grub finished off.

Our clothes and things dried off during the 
afternoon, and by the time the chill September night breezes fell we were clothed again and off in the forest for a still hunt. This form of hunting is wonderfully successful if done right. You find a big log in some great grove where one can see a long way in every direction, including the green canopy overhead. While you were walking, all the woods creatures had "froze" and were watching you in silence. Now that you are still they soon forget you and go about their businesses. The tables are turned. A call in the woods off to your right denotes game in that direction; a motion in the leaves overhead discloses a squirrel moving in the tree tops; a faint rustle in the dead leaves discovers Bunny-rab hippity-hopping along, totally unaware of your presence. A short stalk in the direction of the call, a quietly raised gun, from your very seat itself, will often get meat and the Mouse-trap is again ready for business. This afternoon I came upon a large brook pickerel, motionless in a pool in the brook, and how to have fish for breakfast immediately caused considerable scheming. First, I blocked up both ends of the pool with rocks; next I cut a broom of a young beech sapling, and finally, by manœuvring the pickerel to the shallow end of the pool I brushed him out on the stones with several vigorous 


\section{BOY CAMPS OF LONG AGO 193}

sweeps of the broom. Not that I got him the first trial; but after he and I had both had considerable exercise and both got rather excited, he made the mistake of running into the broom-to his undoing!

A little farther up the brook bed two woodcock jumped, and one fell to "Diana's" sharp report. Back to camp, for dusk was coming on and the whip-poor-wills were already tuning up. An orange glow in the trees showed the big chief already busy over the tea pail and another squirrel hanging up on the game pole. I plucked the grouse, cleaned him and broiled him on a sassafras fork while Eber got on a pail of tea and some prunes. In three-quarters of an hour everything was ready to serve, and we touched off the big Nessmuk fire. Instantly we had a blaze six feet high, glorious and warm, and plenty of light to set our table on the grub box. After eating and washing up, we rested a while and put on the first charge of logs and then we went skirmishing for browse. We lopped the lower limbs of several hemlocks and white pines and towed them to camp. Then, in the bright firelight we stripped off their browse feathers until a mountain of fragrant green filled the rear quarters of the tent. Spreading this out a foot thick we pegged down a canvas tarp over it 
and then made our beds. Old Man Morpheus hovered just outside in the shadows of the forest. We chucked on the second set of logs, sending a shower of sparks up into the trees, and then rolled in our blankets. . . . In two minutes it was morning-such a sleep!

That was thirty years ago, and we boys (and the men, too, for that matter) had no idea of what it meant to go light. To do that was to rough it with a big $\mathrm{R}$, for in those days light compact cook kits and light waterproof tents had not been invented. Nessmuk's book "Woodcraft" had just come out in print and we boys devoured it, finding it good and far in advance of his time. Little did I think then that I was to be the one who would write the legitimate sequel to "Woodcraft" in my own book "Campcraft," but the necessity for it grew with our increasing knowledge of materials and outfit. Nessmuk was fine, with the available things as he knew them, and even at that he had to make most of his outfit himself. But most of his stuff has been superseded by better designs and materials, better tents, light aluminum or tin cooking outfits, warm light sleeping bags, etc., and the boys of to-day have at hand much better and cheaper outfits than we of thirty years ago could possibly make or buy; and the purpose of these 


\section{BOY CAMPS OF LONG AGO 195}

chapters will be to show how up to date wilderness camping is done, how the good of the old ways has been kept, and the bad replaced by practical, light woods equipment. 


\section{CHAPTER II}

HIKING

I BeLIEve that it was the Boy Scouts who first initiated the art of hiking. When I was a boy the game laws opened up much earlier than they do now, and all our camps were hunting and fishing expeditions. We went on long walks with our elders, to see falls, climb mountains, etc., but they never thought of staying out over night. Always a hotel or an inn was their objective point, so that no outfit whatever was carried. But of late, particularly in mid-summer when the fishing is at low ebb and the hunting season far off, troops of boys under able leaders or scoutmasters, take long hikes, involving spending several nights out of doors and the preparing their own food. The outfits are very light, not over fifteen pounds per boy, and generally ten; they do not need the stern outfits that we had to take, for Jack Frost is not around the tent at night, and the stay is short that no great weight of anything must be carried. A light single mackinaw blanket will do perfectly 
to sleep in; a cup and fry pan answer for cooking; and if it rains, the party retires to the nearest barn for shelter.

With us, no single blanket sufficed, unless we expected to shiver all night or stay up and feed the fire; if it rained and the woods were dripping we needed clothing that would let us push right on regardless ; ammunition and rifle were to be considered in the load, and only good meals properly cooked would sustain us without intestinal upsets. Leaving this kind of camping for a future chapter, let us look over the essentials for a good hiking outfit.

Obviously a troop of twenty boys under a leader cannot take along a big tent. The lightest thing that would house them would be a large wall tent weighing sixty pounds. Most hikes are made along country roads through picturesque country, with some well known bit of scenery or a good fishing lake or stream as the objective. On the latter it is possible to cut tent poles, but the former is generally in too civilised country for that. The troop chooses a spell of weather when it is likely to remain clear, and sleeps at night in some summer house or barn chosen in advance by the leader and arranged for. In a simple hike of this character, it is just as well to omit the tent feature altogether, 


\section{8}

\section{CAMPING FOR BOYS}

but by providing three or four light tents, a great deal more freedom of movement is attained. A light "Dan Beard"' khaki tent, costing seven dollars and weighing ten pounds will sleep four boys on a floor space of six by seven feet, and four of them distributed among the party will accommodate sixteen. Perhaps as good a summer shelter scheme as any would be to take along several light "tarps" of thin paraffined waterproof muslin. These weigh but $41 / 2$ pounds and cover a floor space of $12 \times 13$ feet. The number of ways that they can be set up is legion, but a favourite is just two trees with a rope stretched between and the tarp guyed over it at one end and pegged down at the rear end to make an open leanto. A log or pole staked about two feet high at the rear will add to the head room at that end, and a pole set up in the centre to afford rainflow in every direction will make a big shelter of it and one where the party can cook and later clear the space for sleeping. Each tarp would accommodate eight boys. In the case of a driving rain, a windbreak of leafy boughs, thatched, will be ample to prevent drift under the edges of the tarp.

The Indian teepee will sleep more boys than any other form of tent for the weight. It is best put up with a tripod of long poles outside giving all 


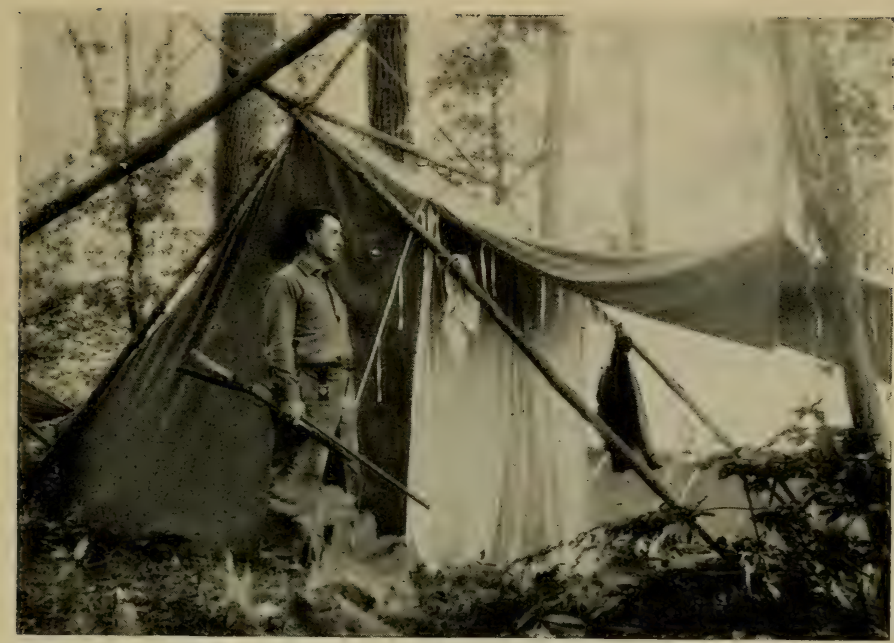

THE DAN BEARD TENT

Also called the "camp fire" tent; a fine model for a party of four boys; plenty of room to stand up in it and a $6 \times 6$ foot size, in brown shelter-clothing, can be had for $\$ 7.00$.

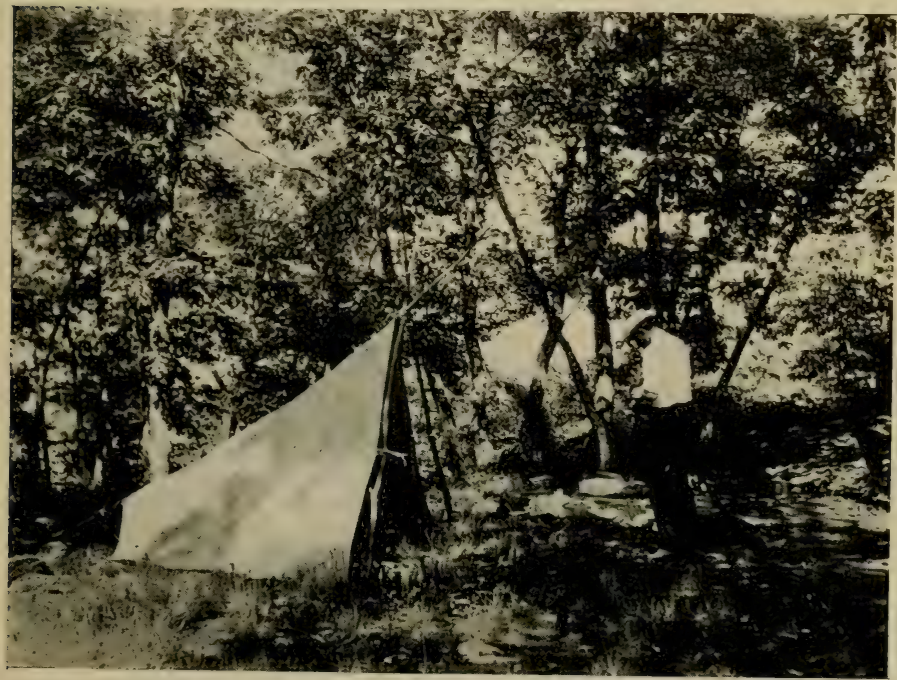

THE FORESTER TENT

Designed by the author ten years ago and since extensively used. A warm, tight tent for two; weight, $4 \% / 4$ lbs.; cost about $\$ 6.00$. 

the inside space for free room. The twelve foot diameter teepee, $101 / 2$ feet high, will weigh thirteen to fourteen pounds in light water proof tent textiles, and will sleep twelve boys, lying like spokes of a wheel.

In cooking food on the hike, the general plan is to deal out rations all around and let each individual boy cook his own food in the manner that suits him best. It is a good scheme, in that it takes the load of preparing food off the shoulders of one or two and develops the individual resource of each boy, and it will work for a short hike. For a regular camp I should not recommend it, for there camp organisation is essential and the work must be divided among the boys that know their own specialty best. Not all boys are even indifferent cooks, and some will surely fill their stomachs with amateur grub that is little better than raw stuff, warmed, and a few days of it puts them on the sick list. However, most boys know how to broil steaks and slices of ham, can fry bacon and make squaw bread, so that if the rations are properly selected a very simple cooking outfit suffices. The Y. M. C. A. boys take along nothing but a fry pan, a shallow tin and a cup, which is plenty for a short hike. The Boy Scout outfit consists of a fry pan with folding handle, a stew pan, a pot 
with cover and a cup, fork and spoon, the whole going in a khaki carrying bag with canvas shoulder strap and costing $\$ 1.50$. In shape and weight it resembles the army canteen, when packed. With this outfit you can boil rice or mulligan in the pot, fry a fish or make squaw bread or flapjacks, or broil meat with a birch or sassafras stick on the side and prepare wholesome food for an indefinite time. For older boys who can drink tea and coffee, a still more extensive cook kit such as the Stopple costing $\$ 2$, gives one two fry pans, a quart pot and two pint pots or cups depending upon how you use them, besides which you have a small wire grate which is very handy. You can get a whole meal in a jiffy on this outfit, but more of it later in the chapter devoted to camp cookery.

For hiking rations, choose easily cooked provisions and cut out the elaborate camp cuisine required by a long camping trip. In the latter you must save every ounce of weight and take along dry provisions, but on a short two or three day hike, there is no reason why brown bread, force, fresh fruits, fresh meat, eggs, etc., should not be taken or purchased en route. If the boys have but fry pan, mixing pan and cup (the outfit costing fifteen cents complete and weighing about six ounces), get steaks, ham, bacon, and codfish for 
meat, potatoes, eggs, flour, baking powder, sugar, prunes, raisins, cheese, dried apricots, force, flapjack flour, onions, salt, butter and lard, and you have enough to keep them all going in good health. Eggs, fruit, and milk can be picked up as you hike along. Breakfasts contemplate bacon and eggs, flapjacks, force and fruit. Lunches should be light on the stomach but sustaining, say brown bread, cheese, raisins and maybe a bit of smoked beef to avoid the necessity of fire making. The supper is the big meal of the day when you can deal out flour, baking powder, steak, potatoes, onions, dried fruits, etc. Each boy makes his own fire, makes a stew of chunks of steak, a cut-up potato, and a sliced onion in his stew pan, does a loaf of squaw bread in his fry pan, and makes a dessert of stewed prunes and apricots with a little sugar in his cup. Vary this with broiled steak and plain boiled potato, or a mess of creamed codfish in the stew pan, but be sure that they get a proper "mulligan" or stew at least once or twice on the trip, for nothing so soothes the digestive processes as a hot meaty stew before going to sleep and it does not take over half an hour to do. In the same way the breakfasts can be varied with boiled eggs, a slice of fried ham, or bacon and flapjacks. Details on the way to cook these for those who have never tried 
must wait for the proper chapter on the subjectwe must conclude with some observations on accessory equipment.

First of all a good belt axe. Not absolutely essential on a plain hiking trip, but, if you have tents along you will need pegs and poles cut, and a friendship fire at night can best be kept going with the aid of an axe even though it is easy to cook a meal with dry dead wood, hand broken. The best and cheapest axe I know of is the Collins quarteraxe, costing 75 cents. Good steel cannot be had for less. Next, a good jackknife-the Boy Scout is a good one, so is the Barlow. Some boys combine the two, axe and knife in a brush knife with ten inch blade, costing $\$ 3$, but I never was keen about it. A 75 cent axe and a $\$ 1$ knife will do all that the brush knife can do and a lot more. Driving tent pegs and camp fire stakes, for instance.

Then you want an electric flasher. The acetylene lamp is a fine thing for regular camps, but on a hike, each boy wants his own light when he wants it, to find this and that in the dark, and the party depends on the friendship fire for general illumination. Pocket flashers cost from 35 cents up to $\$ 1$ and save much tribulation. Next, a waterproof matchbox. You can buy them from forty cents up, or make one with a twelve gauge brass shell with a 
cork in one end. Either kind will float if dropped overboard and you are always sure of a dry match. And, the first paper birch tree that you run across, strip off a thin sheet and wrap it around your matches for emergency tinder. Some time, when everything is wet and you have plenty of split wood but no tinder, it will come handy.

Then you want a compass. You may get lost in attempting a short cut, or get left behind, and it is surprising how even a plain country road goes the wrong way when you are lost without a compass. And, when you come to a fork, it is invaluable in determining which is the right fork.

A piece of candle, some fishing tackle, needle and thread wound around a bit of paper, a small sharpening stone, these and the articles mentioned above all go in a small leather pouch with straps on it to pull your belt through. If stowed in your pockets they will surely get lost and turn up missing when wanted but if kept in the "ditty bag" as woodsmen call it, they are all there and nowhere else. Of course you can get along without these accessories,--borrow the other fellow's when you get into trouble-but-isn't it better to go well fixed in these essential comforts and be the lender yourself when some other boy needs help and the leader calls for volunteers? 


\section{CHAPTER III}

THE HUNTING AND FISHING CAMP

WHILE camping is great fun in itself, most boys like an incentive, such as good hunting or fishing to repay for the labour and toil of getting there and to give something to do during the week or so that one is in camp.

It is a matter, first of all, of carfare. Few boys are so fortunately situated as to be near good fishing or hunting; but there is not a city in tle United States from which a few dollars spent on carfare will not get you within striking distance of some forest lake where there is good fishing, freedom, and, in the season, good hunting.

Now, camping is cheap, infinitely cheaper than any scheme of boarding at a fisherman's hotel or camp, and, for a boy's pocketbook limitations, it is far better to spend the funds on carfare to some wild spot and then let a few dollars' worth of grub and a camp do the rest. Two dollars a week is ample for one's grub expense per boy;-if not, sweep the cook out of camp and get a good one! 
Remains the place to go. Almost any lake or pond in the mountains at least six miles from the nearest railroad station is pretty sure to have good fishing and plenty of wild forest land around it, where a camp site can be found. In the same way, any big stream large enough to show a long flow on the map is pretty sure to have trout or bass in it, if it flows down through a chain of mountains. And, as for hunting, the mountains themselves solve the problem, for they are sure to be forested and to contain grouse, woodcock, rabbits, squirrels, and generally, deer and wildeat. These are the broad principles of picking out a place to go, should you not know of any place whatever. The sporting magazines tell of many good localities, both in their monthly stories and their where-to-go departments so that one by writing them can get good up-to-date information about places. Beware however, of places that are too well knownthey are apt to have been so famous as to be fished out and shot out; I have had better luck by picking. some unknown spot in the mountains, packing my kit and jumping off at the nearest railroad station; seldom have I been disappointed, and usually more than pleasantly surprised. Every State has its mountain chain or bit of wild prairie lake country, and these are the spots to head for. 
The above ought to convince you that the soul of comfortable camping is going light. Now, any one can go light, but it takes considerable experience and study to go light and-right! Any one can go light-if he has the pocketbook to buy a light, fine outfit-but most boys cannot afford it and must make or improvise nearly every article that they take. I always made my own things when a boy-do yet for that matter-and in this chapter I am going to tell you how to make a complete golight outfit that will be warm and comfortable and yet none of it will cost more than the raw materials.

To begin with you need a light, warm, sleeping bag, for most good fishing and all the hunting is to be had when the nights are cold and a single blanket will freeze you to death. The warmest and lightest thing you can make is a light, wool-quilt sleeping bag. At any dry goods store get seven yards of brown sateen; it costs sixteen cents a yard (or \$1.12) and comes 28 inches wide. Cut four pieces out of it 13/4 yards long, or 63 inches and taper one side 8 inches, making the bag 28 inches wide at the top and 20 inches at the bottom. Get ten wool bats of Golden Fleece Australian wool at 14 cents a bat, or $\$ 1.40$. Lay down on the floor one of your pieces of sateen and take five bats and spread them out 
flat on it in thin sheets, overlapping each sheet on the one above it until the whole surface of the sateen is covered. Put down a second sheet of sateen on the first with the wool batting between, pin around the edges and here and there in the middle, and get your mother to sew it all around on the machine and quilt it cross-wise with brown 60 cotton thread. Do the same with the other pair of sateen sheets, sew the two quilts together all around, except two feet from the top on one side, turn inside out, and you have a light warm sleeping bag that will weigh $2 \frac{1}{2}$ pounds and be warm down to freezing. It cost $\$ 2.52$, which is less than a single shoddy blanket would cost and is infinitely warmer and lighter.

Next, you want a tent. The 'Boy Scouts' Handbook" tells you how to make my Forester tent, at a cost of $\$ 2.34$. It sleeps two boys and weighs 6 pounds in 8 ounce duck canvas. I will tell you here how to make another tent which I have dubbed "The Perfect Shelter Tent." It sleeps three boys and weighs $31 / 4$ pounds. Now, all you want of a shelter tent is to keep off rain and mosquitoes. To have this, the roof only is of 8 ounce duck, and the sides and front of mosquito netting, with an extra side to put on with snap buttons when there is a driving rain. The tent when made will give a floor 
space of 6 feet 3 inches by 5 feet wide, will be 4 feet 6 inches high at the front and 1 foot high at the rear. To make the roof, get $5 \frac{1}{2}$ yards of 8 ounce duck canvas which will cost you 99 cents. Waterproof it by soaking in a solution of 4 ounces alum to 10 ounces lime in 10 quarts water. This solution, when it settles clear, is to be poured off into a tub or pail and the tent roof soaked in it and hung up to dry without rinsing. Cut the canvas in half before waterproofing and sew together along the blue line, making a roof 5 feet wide by 8 feet 3 inches long, one foot of which is to form the back, and the rest the slope. Get $61 / 4$ yards mosquito netting, costing about 25 cents and coming 4 feet 6 inches wide. Cut in half, measure off $1 \frac{1}{8}$ yards for half the front, and then cut a diagonal from that point to a point on the end of the goods a foot up from the bottom. This piece is one side and half the front of the tent, and your mother is to hem it under the roof edge along rear foot, slope, and half the front. Do the same by the other side and finish off by getting a roll of grey tape and sewing it doubled all along the bottom and front edge of the mosquito cloth, so that you will have a substantial edge to fasten peg tapes to. Finish the tent by putting in two $3 / 8$ inch grommets in back 


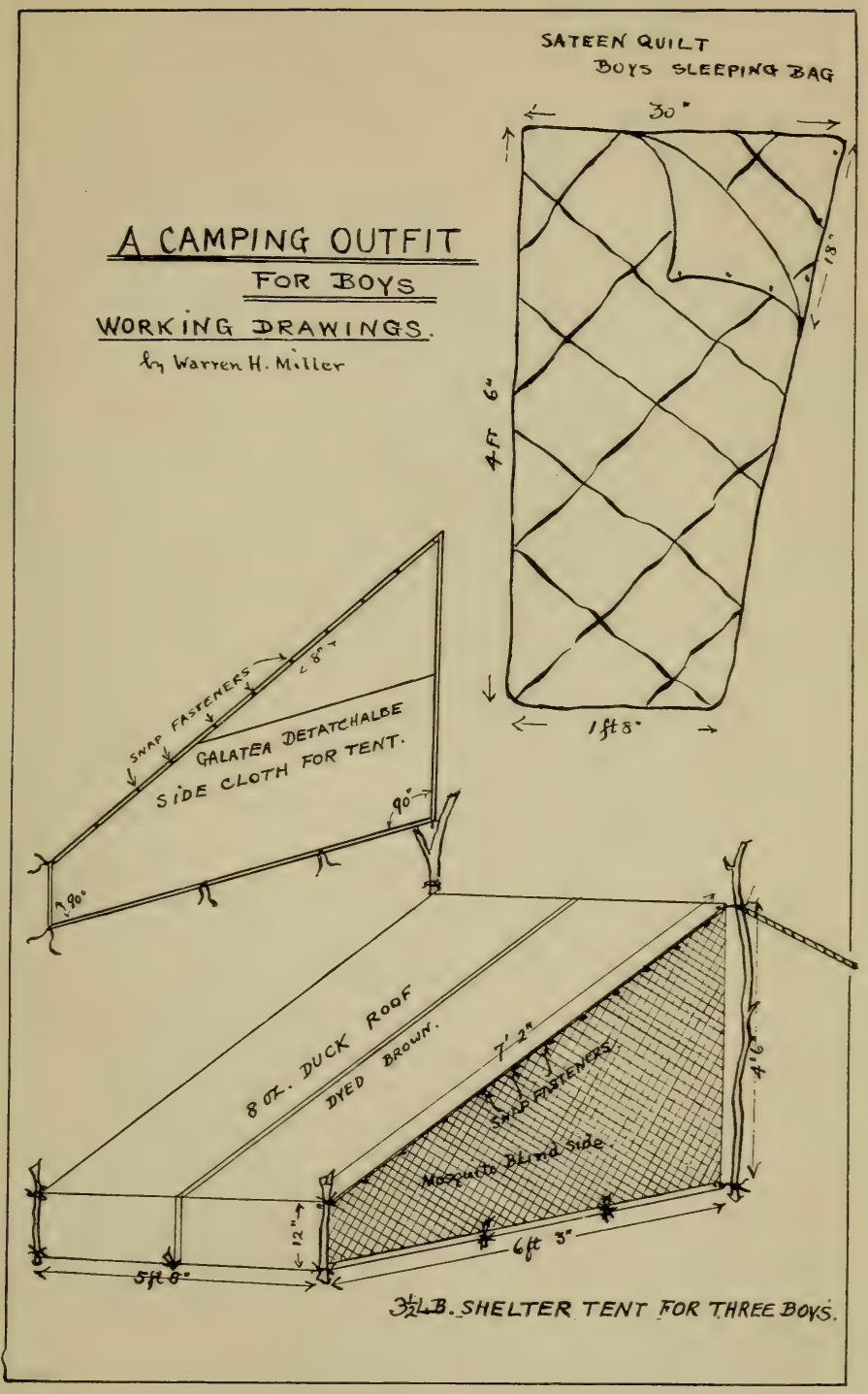



wall a foot up from the ground, three along back of tent and three along the front upper edge. These brass grommets can be bought at any hardware store and turned over with a nail, finishing with a blow of a hammer. Fasten short tapes in each grommet hole, and, along the bottom of the mosquito blind, sew tape ties about every foot and a half.

So finished, it is a dandy little tent, but it needs an extra side to snap on in the direction of rain in case a driving storm comes up. Most storms in the woods will not bother you, but a driving thunder shower requires a side piece. Make it of white galatea, $21 / 2$ yards, cut diagonally and sew together, the diagonal being cut across from the upper corner to a point one foot up from the lower corner. Hem and finish by sewing on snap buttons every six inches. These you get at the notion counter in any dry goods store, 4 cents a card of twelve. Sew the male half of the button on the side of galatea, and the females along both sides of the roof. You will need twice as many females as males, for the same piece of cloth will answer for either side of the tent, depending upon which way the wind is driving.

To put up this tent, cut two short stakes about two feet long and drive in where the back of the 
tent is to come. Fasten the lower tent tapes to the feet of these stakes and tie the upper rear tent tapes a foot up these same stakes. Cut two fivefoot poles and drive them in the ground where the front of the tent will come, 6 feet 3 inches from the rear stakes and square to them. Tie bottom tapes of mosquito blind to the feet of these poles, tie upper front roof tapes to the tops of same poles, guy out taut with some light tent rope, and the job is done. Takes about fifteen minutes. Finish by staking down the mosquito blind sides. where there are tape ties and securing the front mosquito flap with a large flat stone which holds the edges close together yet permits going in or out by simply lifting the stone. When you turn in for the night, take the stone in with you and secure by pinning fast the front inside with the stone. Roll out the three sleeping bags in a row, make a pillow of your spare clothes, and turn in. It will be the healthiest sleep you ever had!

The third important article of a camping outfit is the cook kit. As I said in our last chapter there are a number of light dandy ones to be bought for from $\$ 1.50$ to $\$ 2$-but suppos'n' you haven't got the coin! Well, that's nothing to worry about! Go down to the five and ten cent store and look over the aluminum counter. Two bowls and two 
fry pans will be all you need in that metal (and it may be well to put in here that the reason that aluminum is so prized by campers is not only because of its lightness but because it has three times the conductivity of iron and so will not scorch and burn things anywhere near so easily). These will cost forty cents, and to go with them you want a ten cent enamelled ware cup, a four cent shallow mixing tin about seven inches across, and three 2 cent 7 inch pie plates for covers for your pots and for eating plates. That is all you really need, to bake, fry and boil all you want to in the woods. Add to it sometime later a fifty cent canvas water bucket from the sporting goods store to put all your things in, and you have a dandy little cook kit that will weigh not over two pounds and cost about a dollar. To make your fry pans stowable, cut off the handles with a hack saw about an inch from the side, drill a hole through both stub and cut-off handle, get a short bolt with wing nut at the hardware store and you have a way to put the handle back on again whenever you want it. Aluminum, being such a very good conductor of heat, makes the handle of a fry pan a sizzling hot affair, so that a stick of wood lashed to it in camp will save many blisters. Also, buy a pair of ten cent brown cotton cooking gloves. They are fine 
in the woods, not only for cooking but to wear when paddling or when the mosquitoes are bad; and get a new pair every camp.

You have now the essentials for a real hunting or fishing camp. The accessories, described in a former chapter, will comprise a 75 cent belt axe, a knife, compass, electric flasher, candle, and ditty bag to hold them. To carry food, send to some big sporting goods store for a yard of paraffined muslin, costing 20 cents, and have your mother make up from it as many $4 \times 9$ inch and $3 \times 6$ inch bags as there is material. Simply fold flat and seam three sides and then turn inside out. If you have a rubber stamp set (and most boys do!) mark the $4 \times 9$ 's, flour, pancakes, rice, and sugar; and mark the $3 \times 6$ 's, coffee, cornmeal, tea, codfish, salt, cocoa, raisins, and cheese. Save all the used sugar bags that the kitchen gets for to stow potatoes, onions, prunes and apricots in, and save all the old baking powder tins for stowage of pork, bacon, butter and baking powder. Milk comes in its own can-the smallest tin of evaporated cream. Punch with two nail holes when you get into camp and plug up with small toothpicks. Eleven pounds of provisions ought to be enough to last two boys five days in any kind of fish and game country. For the essential egg, take either egg powder 
bought from the sporting goods stores or take along your eggs packed in the flour in a large friction top tin, or else broken into a small friction top 3 inch diameter by 5 inch can, which will hold fourteen.

With this outfit, when the frosty weather comes on and the fish begin to bite again and the game laws go off, you can pick out a chum or two and take this outfit into the mountains five to eight miles from the nearest railroad station with no fear of freezing at night or running short of good wholesome food. Fill the bags with a pound each of the larger commodities and assemble all the dingbats in one pile in your room. Spread out the tent with its mosquito blind folded inboard; fold up your sleeping bag into a flat parcel in the centre of the tent. Pile the other goods neatly on it. Then fold the tent over them like a big sheet of wrapping paper, first, however, laying your tump strap across the centre of the pile and then rolling. the pack around it. The ends of the tent are tucked over, leading out the tump strap ahead of the folds, and next the whole bundle is secured with the tent rope of which you will want about ten feet of $3 / 8$ inch braided. Now adjust the tump straps to the forehead band so that the pack rides easily a little below your shoulders. The pack 


\section{CAMPING FOR BOYS}

should not weigh over twenty pounds all told, and you can tump it five or ten miles through forest trails and old lumber roads with ease.

The regular Indian tump line has the broad central strap about 18 inches long and two long thongs about 8 feet each. These are laid side by side on the tent or pack cloth, about a foot or more inside the cloth so as to cross the two ends of your pile of duffle. The cloth is then folded in over the tump lines and the pile of duffle made up. Drawing in on the tump lines puckers up each end of the pack cloth over the pile and the outside ends of the tump line are then crossed and tied around the pack.

A word about how to make this tump strap. Get a nice piece of soft leather from your shoemaker, 11/2 inches wide by 18 inches long. Buy two one-inch buckles at the hardware store; neck down the ends of your leather band so as to secure on the buckles with a tongue hole and a rivet. Buy an inch strap a yard long for 25 cents, cut off the buckle and punch six holes in that end. It already has a set of holes in the other end and it then forms your tump strap, which you pass through your pack and adjust to the right length by the buckles on your forehead band. Or, substitute for this short strap through your pack two 


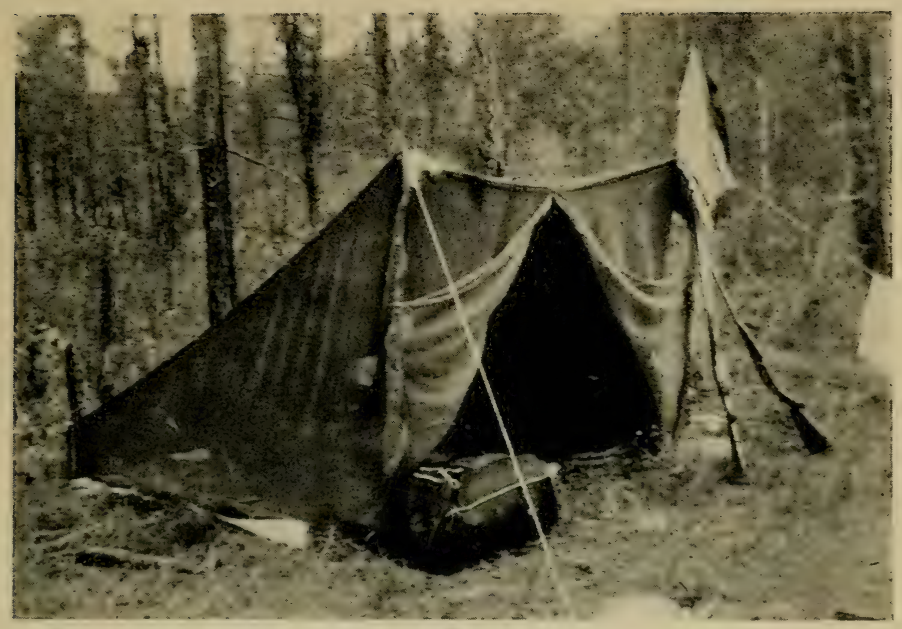

THE AUTHOR'S "PERFECT SIIELTER TENT"

This is the tent described in this chapter; sleeps three, weighs 3 llos.: easily put up, with two leng pegs and two short poles, in less than ten minutes. A fine tent for a boy's hunting or fishing trip.

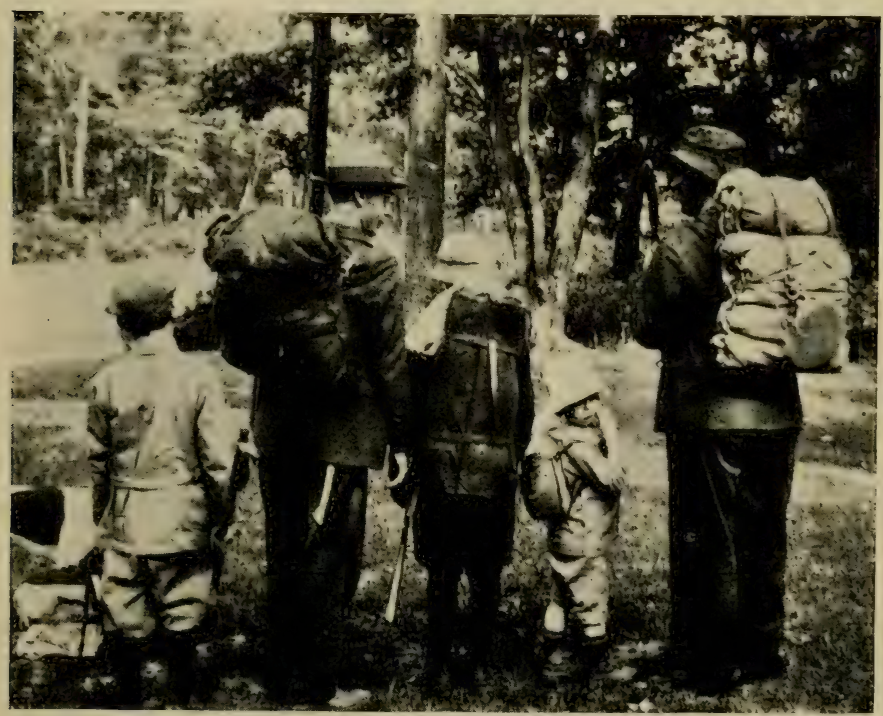

OFF FOR A WEEK'S CAMP

The author with his children and a friend. All tents, sleeping bags, cook kits and provisions for a week's camp are in the various packs carried by the party. 



\section{THE HUNTING CAMP}

long 8-foot thongs of rawhide or braided rope and make up the pack Indian fashion as described above. It is the easiest way to carry a pack, once your neck gets used to the unaccustomed strain, or, if you are naturally thin-necked and prefer shoulder straps, you can make up a shoulder strap harness out of five cent school book straps and two large leather bands.

The point of this entire outfit is that it is light and cheap, and no part of it is useless weight in camp. If the tent is dyed brown with Diamond Dye or the whole parcel wrapped in your rain coat or poncho it will make a more presentable package for the train and railroad station.

Next, get your tickets (some early morning train, so as not to get there too late in the evening); get off at the little jumping-off station, and melt into the forest for a week's good sport! 


\section{CHAPTER IV}

\section{CAMP COOKERY}

WHILE with a big hike, consisting of twenty boys and their leaders, the accepted plan is for each boy to cook his own rations as dealt out; on a hunting and fishing camp for three or four boys it is much the best organisation to elect the boy best fitted for the job as cook, with the next best as assistant cook. The other two attend to firewood and water, cleaning up the camp, airing the blankets mornings and washing the dishes after the meal is over. The cook and his assistant set the table, prepare the food, cook it, and help eat it, after which their work is done and the others take hold. The cook and his assistant should not be required to get firewood or water, both should be at hand in generous quantities, for no meal can be well done with insufficient fuel, nor can the cook leave his job for a single instant to rustle firewood or water. The other two attend to all this, also the night fire and the browse for bedding. It makes an equal division of work, and some boys are temperamentally 
better fitted for axemanship and such muscular jobs while others have in them the making of a first class chemist, which is what a good cook is in essence.

Here is a good grub list for three boys for one week: 2 pounds bacon, 2 pounds pork, 2 pounds rice, 5 pounds sugar, 1 pound raisins, 1 box chocolate or cocoa, 1 pound butter, $1 / 2$ pound coffee, 3 cans evaporated cream (small size), 2 dozen beef capsules, 4 pounds flour, 1 pound cornmeal, 2 pounds pancake flour, 2 pounds prunes, 2 pounds apricots, 2 pounds peaches dried, 1 pound cheese, $1 / 4$ pound baking powder, $1 / 2$ pound salt, 2 pounds side of codfish, 1 quart white onions, 1 quart potatoes, $1 / 4$ pound tea, $1 / 2$ pound lard, 1 dozen eggs, 1 dozen beef capsules, total, 30 pounds or ten pounds to each boy. This list supposes that you are going to catch fish and shoot game for meat or go hungry, that is not starve, but have to live on bacon and codfish eked out with stews in which the meat element is furnished by the beef capsules. These things will all come from the grocer's in a great box, and most of them have paper packages or boxes that add considerably to their weight. First of all transfer everything to all the food bags you can muster; use the paraffined bags for the flours, 
sugar, coffee, etc., which water can hurt, and stow the vegetables, dried fruits and the like in your muslin bags. Put the pork, butter, etc., in cans and stow the eggs in a large can with part of your flour around them. Another way is to get a friction top can about five inches high by three inches in diameter and break all the eggs into it. Such a can will hold fourteen eggs and most of the yolks will stay whole even after six or seven miles of hike.

The night before the expedition, the clan gets together and makes up the packs, distributing the provisions according to the carrying capacity of each boy. One takes the tent, the other the cook kit and the third an equivalent amount of provisions over and above the third portion. No pack should then go over twenty-two pounds. My own son, who is 11 years old and a husky brute at that, carries a twenty pound pack over the mountain trails all day without any great effort.

Starting out from the jumping-off place, the first thing to do is to quit fighting your pack. It is a burden, but if there are no sharp corners nor can edges in it, just get used to it and you will soon forget that it is there. There is no use fussing and fidgetting with it, that will tire you out in no time and do no good whatever. Once well on the 
trail there will be so much to see and do that there will be no thoughts left to expend on your pack. Try to follow old lumber roads and trails in your route through the forest; breaking through straight brush is exhausting and slow even without a pack, while with it it is mighty hard.

Your objective is a little forest lake where there are bass, and wild ducks, with plenty of partridges in the woods, and it is four miles off through the woods and over a mountain or two from the railroad station. You hike along, the leading boy with ready shotgun and (while on the subject of firearms, take but one gun each, no extra rifles or pistols allowed, make one gun do for all game chances, which a shotgun will).

These old lumber trails are fair places for grouse-and we are on the lookout for supper! After about two hours hiking, walking twenty-five minutes and resting five in each half hour, we make out the white shimmer of the lake under the forest trees, downhill. We pitch down through the brush regardless, for we must reach the bank quickly so as to skirt it on the lookout for a spring and a camp site. Choose a spot out on a point if possible, for there is more breeze in such places and fewer mosquitoes. Now the packs are opened and all provisions turned over to the cooks while the 
third boy gets stakes and poles for the tent. It is unrolled and put up by him and the assistant cook, while Cookie assembles the war bags, puts up a pole to hang them over in pairs, makes a stone shelf for his pots, pans and cans and clears a cook fire site some twenty feet to leeward of the tent. Assistant Cook is sent to the spring with the canvas bucket for fresh water, while the tent man brings in a quantity of firewood for the cook fire and piles it near the cook fire site. Then he goes after browse and the clearing away of roots and stubs from the tent floor, while Cookie looks over his layout.

Let's see; we had no luck at partridges on the way in, for Bony missed the only grouse that got up. That's what we brought along that steak for, to tide over the first gap before guns and rods get in their fine work. It is five o'clock and the sun is going down. Assistant cook cuts a springy sapling about ten feet long and this they drive down slantindiginally into the ground with a couple of low forks to hold it up and the long end of it sticking out over the cook fire site. This is called the "dingle stick" in the North and a good cook fire pot pole it makes, too! Assistant cook next cuts a couple of pot hangers out of maple bush; just a twig with a stub sticking out at its upper 
end and a notch cut with a jackknife at the lower end to take the bale of a kettle. Assuming that Cookie has with him the cook kit described in our last chapter, he takes the two aluminum pots and starts a "mulligan" in one of them while rice is doing in the other. Rice swells enormously when cooking and is sure to burn unless it has plenty of water. Three small grabs out of the warbag are plenty and the pot is filled nearly full of water, a pinch of salt added, and the rice stirred in when it is boiling furiously. In half an hour it will be done, when the rice water is poured off for soup stock or added to the mulligan, and the rice steamed a few minutes over the fire before serving. Cookie hangs this over the cook fire which assistant cook has started under the dingle stick, and next fills the other pot, puts in some salt, chops up half a pound of the steak into cubes, slices in two onions, and cubes in three smallish potatoes which assistant cook has been paring. This goes on the dingle stick ahead of the rice and the fire is organised between two short logs so that the rice gets the bulk of the fire after the first big blaze has burnt down. Tin covers ought to go on both pots, not only because they will come to a boil quickly that way but will keep boiling even if the coals are low. 
Cookie now starts his cornbread batter. One cup flour, one-half cup cornmeal, half teaspoonful salt, one tablespoonful sugar, two teaspoonfuls baking powder, mix all together in mixing pan. Add one egg and some milk water from evaporated "cow" can, and finally a teaspoonful of melted butter. Stir all together. Assistant cook has been greasing one fry pan meanwhile, and now you pour the batter out into it. It should be just thick enough to pour slowly with the help of a spoon; if too thin the cake will not come up. Over the fire with it, out on the ends of the logs with a bed of coals raked under. The second fry pan is put over it and a lot of brands stolen from the fire heaped up on it and blown to a separate fire. Watch that cake carefully for it is easy to burn it. Keep the coals under it free from flame and lift off the upper pan occasionally to see how it is getting on. The upper fire seldom burns it, and can be kept going merrily.

Assistant cook meanwhile has cleaned out the mixing pan and you fill it with mixed prunes, apricots, and peaches; add two tablespoonfuls of sugar and a little water and set it to simmering somewhere on the back of the fire. Meanwhile see that the two pots are boiling steadily and stir them occasionally. By the time the cake is done and 


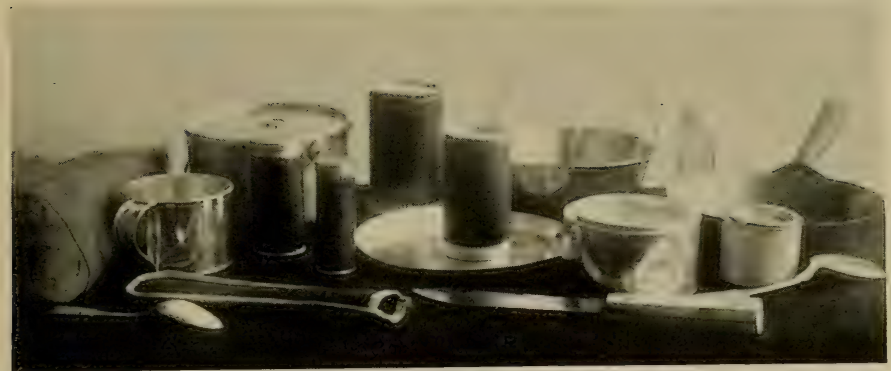

THE BOY SCOUT COOK KIT

As furnished by the N. Y. Sporting Goods Co. Fry pan, stew pan with cover, mixing pan, plate, cup, knife, fork and two spoons. Also note tins and paper containers with tin top, for small provisions. A oneboy list

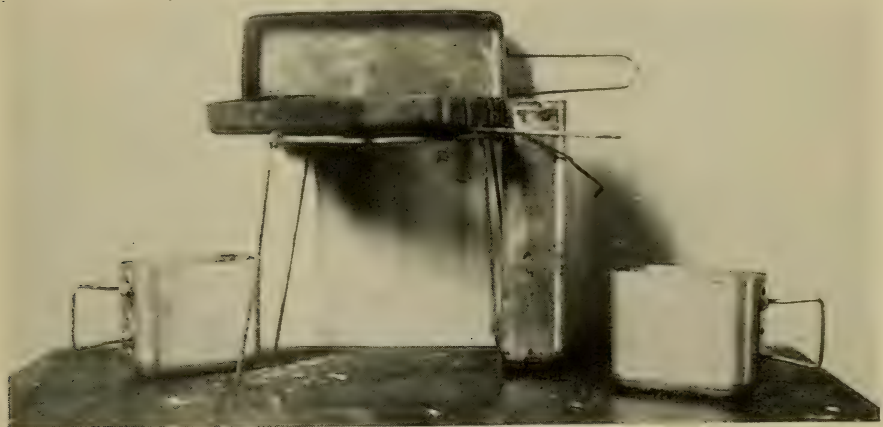

THE STOPPLE COOK KI'T

Two steel fry pans, which also make a fine bake oven, a quart pail, two large pint cups and wire grate; weight, 2 lbs. Whole kit goes in long pail and will fit in your pocket. There is room for forks, spoons, etc., besides the grate and all the detachable handles, inside the fry pan. A two-boy kit.

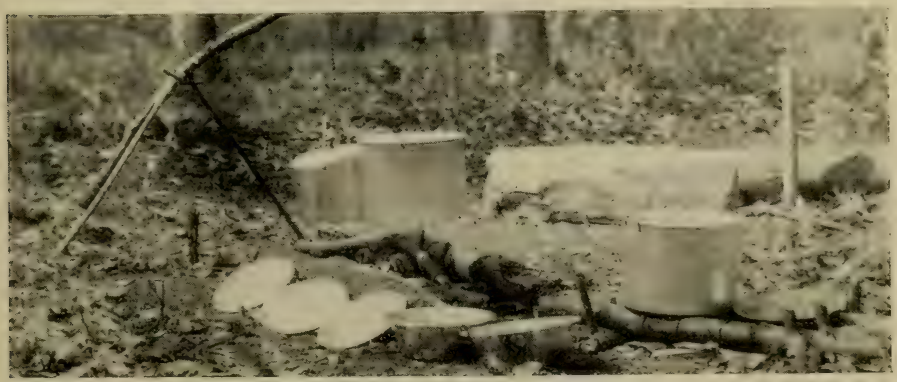

THE FORESTER COOK KIT

Two gallon aluminum pots, one 3 -qt. pail, 2 mixing pans, fry pan, 3 baking pans, 3 cover plates, aluminum 9 -inch plate, and cup. A kit for four boys, each bringing along his own table set. 

set aside, it is time to set table and call the third boy off his browse job. The Big Ceremony now takes place-tasting the mulligan! A spoonful of it is scooped out and blown cool, while cookie and assistant cook each take a solemn sip. Judgment is pronounced, and the same is done to the rice. If "Can't be beat!" pour out rice water and extra mulligan water into a container and add three beef capsules for soup. In a few minutes you announce soup and cornbread, set out the butter, serve the rice and mulligan on the plates and set water to boil in both pots again, one to use for washing water and the other to draw tea as soon as it comes to a boil.

By the time the soup is down, the rice and mulligan have cooled enough to "go at with a long" pole," and the tea water has come to a boil. Add three pinches of tea, set aside four minutes to steep and clean the cups for tea. It is ready to pour in four minutes. Add evaporated "cow" to taste, pass around the sugar bag and "hop to it." After it and the rice and mulligan have disappeared, bring on the fruit stew, by the end of which every one is full to the brim and that camp will sleep like a major! The sun has set, and if Third Boy has been busy the Camp Fire is ready to touch off. Cookie and assistant cook attend to 
this duty while all hands wash up. Then there is casting for bass by night, frogging, browse picking and sleeping bags to look to before turning in. Cookie ties all the food bags in pairs and hangs them over his pole, sees that all cans are closed and all covers on, throws a tarp over the outfit and is then sure that rain, squirrels, porcupines and such small marauders will not steal any food during the night.

The remains of the firewood are put on the camp fire and all hands turn in for an early start next morning, for daybreak is the time to hunt and fish. Never chop wood at night; it is as much as your life is worth.

Next morning Cookie is up betimes; do not let the crowd get out without a substantial meal. Pot No. One boils coffee; one grab of grounds to each boy, let boil five minutes and then simmer until wanted. Get out the bacon can and fry two slices for each boy. They should go over a hot fire and be taken out and put in a covered container as soon as they show translucent on both sides. Do not overdo or they will be just dry chips. If fish were caught the night before, have assistant chef cleaning them while this is going on. With the bacon fat still red hot put in two fish side by side, head to tail in one fry pan, first pouring off 
a little bacon fat in a cup for pancakes, and making up with a hunk of lard out of the lard can. Never put fish in cold fat.

Put a tin cover over the fish and keep assistant cook maintaining a small even fire under them. Meanwhile get out the mixing pan and the pancake flour, add enough milk water to make a batter that will just pour off the spoon and you are ready for flapjacks. Pour all your bacon grease in the cup into the second fry pan, let get sputtering hot over the fire, pour all back that will drip and then pour on enough batter to fill the bottom of the pan. Hold over hot fire, raising the edges occasionally with your hunting knife and giving a shake to keep from sticking to pan. Then-one, two, THREE! and over she goes! Most boys are afraid to flop high enough, with the result that the cake lands on the side of the pan, not having a chance to make a complete flip. However, six of these are enough; have on some peaches stewing in the second pot and serve breakfast; coffee, bacon, fish, flapjacks and fruit. Oatmeal is too mussy about camp; corn mush is better, but the above is plenty grub enough.

The whole party goes out hunting and fishing forthwith, letting dishes and bedding to take care of itself. There will be plenty of time later when 
the sun is up high, around eleven o'clock. Along about eleven they all straggle in, hungry, of course. For a midday lunch, chocolate, cheese, raisins and broiled birds are ample. Put on one pot to boil, stir up a teaspoonful of chocolate to each boy in a cup with cold water, stir into the boiling water, add milk and sugar to taste, and let boil for twenty minutes. Two grouse are enough for the whole outfit. Clean and broil before fire on sassafras fork with a strip of bacon skewered to the bird inside. His own fat will do outside. For breadstuff you will want biscuits or squaw bread. They are both made of the same ingredients. One cup of flour, one-half teaspoonful salt, one heaping teaspoonful baking powder, one lump of lard or butter as big as your thumb. Work latter thoroughly into flour with hands, add milk water little by little stirring the dough with a spoon (never with the hands for they are too warm) until the whole mass is a lively lump of biscuit dough. Press or roll out flat on a plate, tip into fry pan and set over fire. To make biscuits, cut up with the baking powder can top and set in floured fry pan, putting the other over it and building a fire of brands on top; to make squaw bread, put in floured fry pan, hold over fire a few minutes until the bottom has a firm crust and the cake has begun 


\section{CAMP COOKERY}

to rise, then tip up fry pan with a stick through hole in its handle, build up a high-flaming quick fire in front and watch her rise and brown on top!

This meal brings the cook around to supper again. For variations serve creamed codfish, made by boiling shredded up pieces off the steak in three waters to get out the salt, pour off third water and add a thumb of butter, some "cow" and a pinch of flour, stir thoroughly while cooking and serve hot. Always welcome, in a meat and fish diet. Never omit the mulligan, making it sometimes of bird or rabbit chunks, other times with the beef capsules alone, always having the onion and potato present for that is what they were brought along for. For variation in fruit, try "speckled pup," which is just raisins cooked in rice; also occasionally serve the prunes "as is," the idea being to cut down the midday cooking as much as possible. In fact, to do good hunting you ought to range far and wide and take along a midday lunch in your pocket, cooking enough extra to provide for it at either breakfast or supper. Woods lore allows but two meals a day, indeed the Indians hold that no man can remain sound and healthy in mind and body and eat three times each sun. Once in a while serve eggs and bacon for breakfast, first making sure that you have eggs enough for cornmeal. 
In a week's camp a dozen eggs will give enough for one go of bacon and eggs and the rest will be saved for corn bread. About the third day out you will not want but two meals a day, and begin to see that the Indian was right, for his country and mode of life. 


\section{CHAPTER V}

ALL ABOUT THE DIFFERENT TENTS

WHY is it that when you pick up any sporting goods catalogue, you find more than a dozen different kinds of tents? Why isn't the army wall tent the best if the Army uses it, and why, then, all these other kinds? This question strikes every boy's mind as he glances through pages and pages of tents in all sizes and weights and kinds-why not one army tent of a variety of sizes and weights and let the rest go? The question gets more acute still when he starts in to buy one, for of course he wants the best tent for his money, and he can afford but one.

For a boy the answer depends upon the country he lives in, and a knowledge of just why each kind of tent was invented or developed will help him more in deciding than any other information he could have. I myself have invented no less than three different kinds of tents, the first of which, the Forester, has become famous, and is to be found in every sporting goods catalogue put out by the large outfitters. Yet I own three others 
and use them all at one time or another. That is because I range so far and camp in so many different parts of our big country. For, the same tent that is ideal in the Eastern woods is not just the best for a canoe trip down some Canadian river, nor yet for a pack-and-saddle trip in the Rockies, nor yet in the deserts and mesas of the Southwest, nor yet again in the sand dunes of the Atlantic seaboard. True, any tent not too large or heavy will answer in all these countries, and there are a few models which nearly fit them all, but there is no one best bet that will beat all the rest for all of these countries.

For boys the first consideration is lightness. If you make it yourself of department store duck, the cloth will weigh about half a pound to the yard, so that a very few yards will run into a lot of weight. If you send to a large outfitting store and buy one of their patent waterproof tent cloths you will have to pay considerable for it, some forty cents a yard, so again the fewer yards the better. Again a tent is an indivisible load, so that for a large party of boys, one big enough to house them all is going to make a big burden for some one, and it is better to take along two or three small tents, each sheltering three or four boys, and no tent weighing over eight pounds. 
To begin with the wall and A-tents: These are of the closed tent type, that is, even with a fire in front their walls are at such an angle to the fire that they reflect no heat inside, and the tents are damp and cold in wet moist woods, near river banks, etc. For sand camping where no moisture exudes from the soil at night, and for mountain work where a dry site can be found with no deep forest duff underneath, they make a good type, because on both seashore and mountain the wind is forever blowing strongly and you must keep it out or get chilled down. For snow work it is also very good, particularly if there is room at one end for a light sheetiron tent stove which can be slipped over your cook kit. Many is the night I have slept in one, with the blizzard roaring outside and the snow settling in tons on the roof, while inside all was cheerfulness and warmth as the little tent stove gave out a ruddy glow and the carbide lamps lit up the interior. Many's the night I have slept in them to the rumbling accompaniment of the surf, while the wind whistied and howled across the sandy beach and the hum of mosquitoes pitched a high keynote just outside the gauze door front!

The Snow tent, is a modern modification of the wall tent which cuts off superfluous canvas and 


\section{2}

provides a reflecting rear wall. It is, so far as I know, the invention of David T. Abercrombie the well-known outfitter. If you shear off the rear roof of a wall tent from a point on the ridge about two feet back from the front peak down to the back wall, and replace this canvas with a flat triangle of canvas you will have saved a lot of roof cloth and improved the tent both in weight and in heat-reflecting properties, and you have made a Snow Tent of it. For all small sizes, sleeping three or four boys, it can do everything the wall tent can, is lighter and warmer. You do not need any height at the back of a small tent, that is where your head goes when sleeping, and you use the front for standing-up room.

Another closed tent, very popular in the West, is the Spike or Miner's tent. It is a small pyramid of canvas, with very sharp slant; only needs one pole inside to put up, stands any amount of wind, and where a dry site can be found is a light good tent for three or four boys. Its only standing room is, however, under the peak so that it is a trifle crowded for more than one at a time to dress in.

But, in the Eastern and Northern woods, where the forest damp is sure to arise like a mist at night from the soil, you want an open tent with a camp 
fire in front. A closed tent gets damp, and everything in it wilts from the mere exudation of mist from the layers and layers of mouldy wet leaves under the very floor of the tent, and if you take a ground cloth to keep this down, you have at once added materially to the weight to be carried. And so we get the Baker and leanto tents, so much used in the North Woods and Canada. For four boys, or three, they are about right. Put up with a rope stretched between two trees, or a pole nailed across two trees and the upper rear corners guyed out to pegs, you build a fine backlog fire in front, completely drying out the duff underneath and warming everything and everybody in the tent. The roof reflects the heat rays down on the floor of the tent, and so long as an ember yet glows its rays will continue to reflect down from the tent roof upon the sleeping boys below. A small rain flap or verandah guyed out in front keeps out driving rain and yet does not require the fire to be too far away. Altogether this tent is one of the best for woods camping for a party of three or four boys. In the larger sizes it loses a good many of its desirable qualities and requires too large a fire for the energies of a parcel of boys. It must not be over seven feet deep, for the heat intensity of the campfire varies as the square of the distance, and 
even nine feet of depth will give you only $49 / 81$ of the heat of the seven foot shanty tent. The Perfect Shelter Tent, described in Chapter II, is one of the best modifications of the shanty tent.

Coming next to my Forester Tent, we have one ideal for two boys. It is notably the warmest tent made, for all its angles reflect fire heat; it has a big floor space for its weight, a triangle 8 feet in a side for $43 / 4$ pounds weight, and two of them make not only an excellent camp for four boys with the same camp-fire heating both tents, but a pole can be put between the two and a "tarp" stretched over it, pegging down along the bottom and making a long lodge of the two tents and tarp that will accommodate eight boys on about 10 pounds of weight. It is hard to describe the appearance of the Forester tent in words, the illustrations tell something of how it looks, and the patterns and directions for making it may be found in the "Boy Scouts' Handbook." It must have the hood feature in front to keep out driving rains and yet let in the fire heat.

The Forester requires three poles to set up. They are easy to find in almost any thicket, but in canoe trips where one picks out a site as the sun is setting and gets right at the cooking of the evening meal, the tent should be the simplest possible 


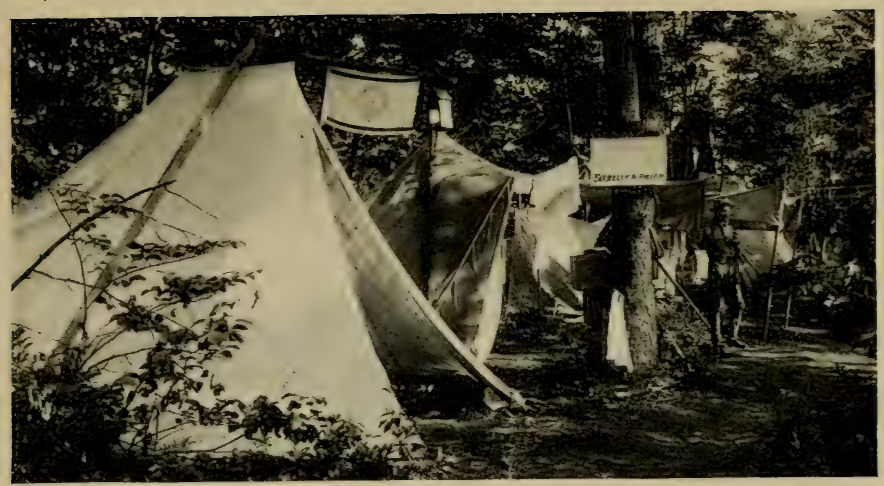

AN ENCAMPMENT OF THE CAMP FIRE CLUB

The tent in the foreground is a canoe tent.

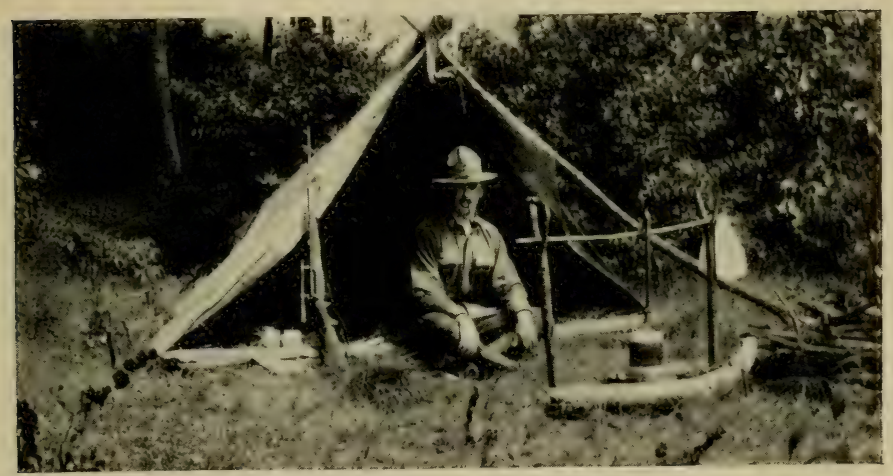

IN CAMP IN A FORESTER TENT

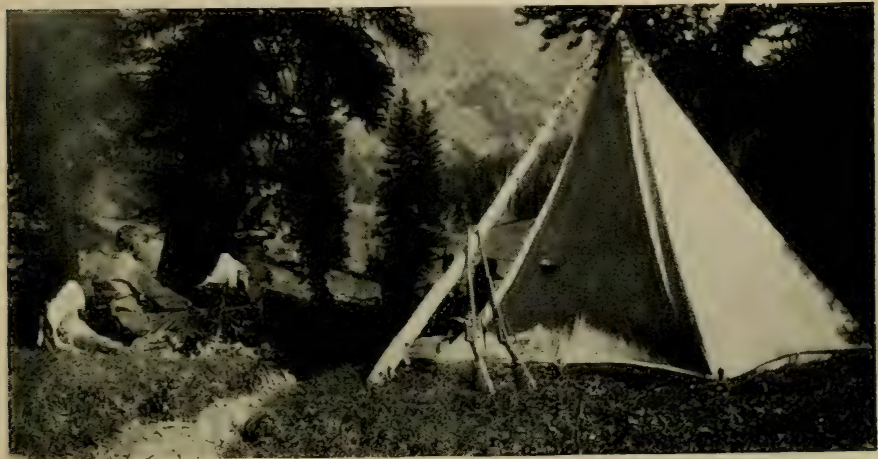

THE WESTERN MINER'S TEXT

An excellent model in windy, mountainous countries. 

thing to erect. To this end we get two types of canoe tent, the Hudson's Bay and the Canoe types. Both are erected with a rope to which the ridge is tied, or the Canoe type when made without ridge needs but a single short pole which may even be one of the canoe paddles. If no trees are available on the stream bank, cut two shears or short poles, straight or crooked, and run the ridge rope over them; pegging down to ground. Rope is always available on a canoe cruise, for you must have one for a tow rope, and most river points that are free from mosquitoes are windy, and so the Indians and trappers of the North devised the Hudson's Bay tent. It is an A tent with rounded ends. The ends are not only to give more roomthey do, lots of it, where it is most needed to pile your duffle in while the sleeping bags, side by side, take up the main floor of the tent-but, further than this, these rounded ends give an end strain to both ends of the tent so that it cannot tumble over once the ridge is up, even if you only use a club and a pair of shears instead of a rope. Such a tent will stand a blizzard, a gale, a thunder squall with equal ease and, with the flaps thrown back and a fire out in front, will warm up after a fashion from the fire heat while you are preparing the evening meal. A modification of this tent which I 
published in Field and Stream two years ago and dubbed the "Blizzard Tent" is, in effect, a Hudson's Bay with triangle ends instead of the rounded ones, and, for small sizes, such as $6 \times 5$ feet main floor space with three foot triangular ends, a single peg at the peak of each triangle or eight in all suffice whereas the regular Hudson's Bay requires from 12 to 22 pegs.

The Canoe Tent retains the rounded front of the Hudson's Bay, but is considerably altered at the rear. It is meant to do away with the crowded interior space of the latter tent and will sleep three or four comfortably. To get this room the rear wall is made from $1 \frac{1}{2}$ to 2 feet high and 7 to $83 / 4$ feet wide and held up by long stakes to which the upper edge of the wall is tied, while the bottom uses the same stakes as ground ties. From this wall the sides of the tent stretch out to the peak and front pegs in flat triangles so that there is plenty of sleeping room and reason. able space near the front pole to stand up and dress.

A final tent, and one that every boy should know well, is the Indian teepee. They are not hard to make, and, for a permanent camp or one where quite a party of boys, say eight or ten, expect to reach the site by team or boat, they make 
a great tent. The two big difficulties with a teepee are finding enough straight poles for it, and keeping mosquitoes out of it in summer. Most camper's tents provide for protection against two things, rain and mosquitoes. If they do not do that they are not tents at all, no matter whether compact or light, or handy to stand up in or have any other feature of excellence. But, for a crowd of boys who like to do things Indian fashion, to emulate all the finer qualities that ennobled the Red Man at his best, a teepee is the starting point for all the club activities. To make one covering a ten foot circle and sleeping eight to ten boys, get 26 yards of 8 ounce duck canvas and sew up to form a rectangle 21 feet by 10 feet. Cut out a semicircle of 10 feet radius out of this canvas and make the smoke flaps, door, etc., out of what is left over. The smoke flaps are 5 feet on the outer edge and four on the edge sewed to the body of the teepee, the upper edge of the flaps 2 feet long and the lower edge 1 foot. A strip 8 inches wide should be gotten out of the left-over canvas and sewed to the upper side of one edge of the teepee so as to form a flap with the lacing peg holes. Cut out a semicircle with 1 foot radius from the upper peak of the teepee, hem all around and work in eyelets enough for twelve pegs, and the teepee is 


\section{CAMPING FOR BOYS}

ready for dyeing and waterproofing. Use the lime-alum solution described in Chap. II and dye red, yellow, or brown to taste. An ornamental border is next painted along the bottom of the teepee cloth and the totems of the band put on. The main border is reserved for decorations commemorating the various camps of the tribe. Such a teepee will weigh 14 pounds and cost $\$ 5$ for materials. Once in possession of it your tribe can make stick beds, a teepee flap for the door, a hood to go over the pole top, stick back rests, ornamental birch teepee pegs and lacing pegs, and decorate the interior with skins and rugs and be as Indian as you wish. It is a very practical tent for cold weather camping; for summer it had better be pitched where the mosquitoes are not too thick, or some of them will find their way in via the top. However, with a fire going inside, even if only a small smudge, this mode of entrance is not likely to be patronised. I have had great times inside of many teepees, some of them real Indian ones. With the teepee fire going one can cook, and hold council, and do all kinds of woodcraft work, tell stories and generally live in the forest much more comfortably than with any form of white man's tent, most of which are merely sleeping spaces, whereas the In- 


\section{THE DIFFEREN'T TENTS}

dian's lodge is his home. Here he is out of the wind and dew and cold and insects, here he can throw off the outer garments of the trail and be at ease, here he can work and live and prepare food in peace, and most boys who have tried the teepee, are agreed that it is the greatest of tents -once they have learnt how to manage the fire. For the white man is prone to get too big a fire. A little one, of real dry woods giving out heat, not smoke, is the Indian's way. The white man piles on sticks, wet, damp and dry until a huge smudge and a thicket of flames is under way. It is far more than the smoke flaps can handle and the teepee immediately fills with smoke until no one can stay in it without crying eyes. The Indian builds a small bright, hot fire of perfectly dry sticks with the damp and dubious ones to one side, which latter are not fed on until dry. A few short thick billets are reserved for the night fire. After grub is through and the council ended, a bed of hot coals is left and on these are placed the two short six inch thick billets. These smoulder and char for hours and when they are partly done two more are started above them. The last of their embers will be alive by sunup, and meanwhile the teepee has had the chill and dampness off it all through the sleeping hours of the night, 
and its temperature is considerably above that of the outside forest.

In selecting your tent, think over the kind of country you will camp in most, your facilities for getting there, the prevailing wind and weather, the insect life and then pick out the tent which best suits your style of camping. For a permanent camp where you go in and stay in one spot for two to four weeks, a teepee will be hard to beat if you can cut poles for it, a wall tent if straight poles are scarce. For a canoe trip, the Hudson's Bay and Forester give two tents that have been eminently successful in that kind of service, and, for back pack trips into the mountains choose shelter tent or Forester depending upon the number to go. For sand and snow work a spike or canoe tent closed, or for a large party a wall tent with a tent stove is your solution, and for camping in dry countries no tent at all is the big idea-just a tarp to throw over your face and sleeping bags. 


\section{CHAPTER VI}

\section{CAMP FIRES}

THE camp fire is the one thing that boys are prone to be most careless about. It is the sign of the tenderfoot-that huddle of sticks and twigs laid on any old way and requiring one or more boys to be forever feeding to make it give any flame at all. But, when the Old Scout builds one, you notice that he does the job once for all, gets a fine strong fire the first thing, does not seem to have to tend it at all, and didn't apparently lose any time or labour in making it.

There is a whole lot of knowledge that went back of his seemingly smooth and easy performance. What woods to use and what to reject, how to start and build up the fire, how to arrange its structure for the purpose intended, how to get the most out of every billet of wood put on the fire-all this know-how was what saved his back and his arms and his axe edge, while you-well, you remember that last fire, how it took forever to get going, went out the minute your back was 
turned and seemed to use up a forest of wood to keep alive!

In the first place the Old Scout knew what he wanted that fire for. If it was for the general camp fire for heating the tents, he built it with a backstop of a big flat rock or a five-high back of logs laid one above the other against two leaning stakes. He did not propose to lose half his heat and light by letting it radiate out into the forest but rather built this backstop to throw that heat and light back into the tents where it was needed. If he wanted a cook fire he avoided anything that would grow into a conflagration, and confined it with logs or stones so that there would be something to rest pots and pans on and confine the heat under their bottoms. If he wanted light alone he built a tiny beehive crib of small sticks so that each stick would get all the air it needed to make a bright flame and not become a live coal too soon. If he was using a reflector baker he built a high back of small logs slipped between pairs of upright stakes and laid his sticks upright against them so as to get a high hot quick flame soon done-but so also would be the biscuits. Finally, if he had to build his fire on deep snow, he laid a groundwork of small logs on the snow and built up his fire on them, so that the embers 
would not melt the snow and sink down putting his fire out for lack of body.

Maybe you watched the Old Scout start a fire, and noticed how he used scraps of dry leaves and twigs scraped up out of the forest duff if the woods were dry, but if they were damp or wet he left them alone and instead broke off a few dry sticks from the under branches of the nearest softwood tree and then took out his jack-knife and whittled a little Christmas tree of shaving, leaving each set on its twig and sticking three or four of them in the ground close together. Then he unrolled his matches from a covering of paper birch, tore off a piece of birch bark from the roll and lit it with ONE match. And, how that little piece of bark did sputter and flame like a wax candle! and how quickly the little trees of shavings caught, even though it was raining, and how the wigwam of split sticks that the Old Scout built over his burning treelets did burst into flame!

And then, you noticed that before he did any of this he had his pile of wood, enough for a substantial fire, already at his elbow so that he didn't have to leave it an instant until he had a roaring fire. And, if you knew something about the forest trees and were curious, you would see that most of his first logs were birch, white or yellow 
(the gas oil of which "blows its own fire," as the woodmen say) and there was a lot of hickory, and white oak and split blackjack oak for the cook fire and plenty of dry balsam and pine for the main camp fire, so that we could have light as well as heat.

Almost every boy who loves the woods wants to be the Old Scout of his band, and, let me tell you something, boys do not give the leadership to any one in the woods but to He Who Knows. You. may be big and strong and the best fighter in the bunch, but the leadership goes to the quiet boy who seems to know all about how to do things in camp and trail, who does things better than any one else, and gets results quietly and efficiently every time. Beware of the boy who knows how things should be done but cannot do them himself. He may talk a good deal-the rest will watch and soon he makes a mess of it-and he gets the nickname "Professor" - while the leadership goes to the boy who makes good, even if his way is not the best.

The great game of woodcraft is technical, as technical as civil engineering: There is a lot to learn, and while some one who knows can tell you how in print, until you have practised at it yourself until you know how, your wooderaft is of the 
"Professor" type. We boys once made a camp for the sole purpose of building and trying out a variety of fires-and that at the tender age of twelve years! Some of those fires I make to this day, and I could build them in my sleep!

Old Nessmuk, the Pine Marten, was the first to put the backlog fire into print. We use it to this day, practically unmodified. Two two-inch hornbeam or red oak or red maple stakes are cut, four feet long and driven into the ground on the fire site, leaning slightly backwards and facing the open tents. Why these woods, so carefully mentioned above? Because they are nearly unburnable when green, and you do not want the fire to burn out these stakes and let your whole back log screen tumble over in a heap. The fire eats out the bottom $\log$ in time, and attacks the feet of these stakes, and if of any old wood they will surely burn through in no time. In sandy country green pitch pine will answer the same purpose. Against these stakes are piled, one on top of another, five four- or five-inch logs, three feet long. They are chosen of red oak or red maple or green pitch pine, green balsam or sour gum, for the reason that these will not burn out quickly and the logs are wanted to last and reflect heat and light into the tents. Two short billets of the same 
woods are next cut and staked against the back$\log$ s on each side for andirons. They are essential to get plenty of good draft, without which most fires smoke and smoulder and act like real tenderfoot blazes. Then, to hold the fire together, stake a forestick across the front of the andirons and you are ready to build the fire proper. First, a roll of birch bark, then a huddle of dry leaves and small twigs, or fresh shavings if the woods are wet. Then, on these, small dry sticks broken from the dead under branches of surrounding oaks or spruces, never picked up off the duff. Now two long sticks laid diagonally across the andirons from forestick to backlogs, and on these five or six assorted logs of birch, maple, pignut hickory, chestnut and white oaks. These are not laid parallel but slightly crossing, leaving plenty of room for flames to get through. This fire is next well chinked with small dry sticks thrust down through the upper logs into the starting fire below. It is best set off just at dusk, and is built about five P. M. while the chefs are cooking grub. It takes an hour's chopping to get twenty fourand five-inch logs three feet long with a belt axe, and, using seven for the structure of the fire, you have five for the main body and eight for two charges of night logs. When it gets too dark to 


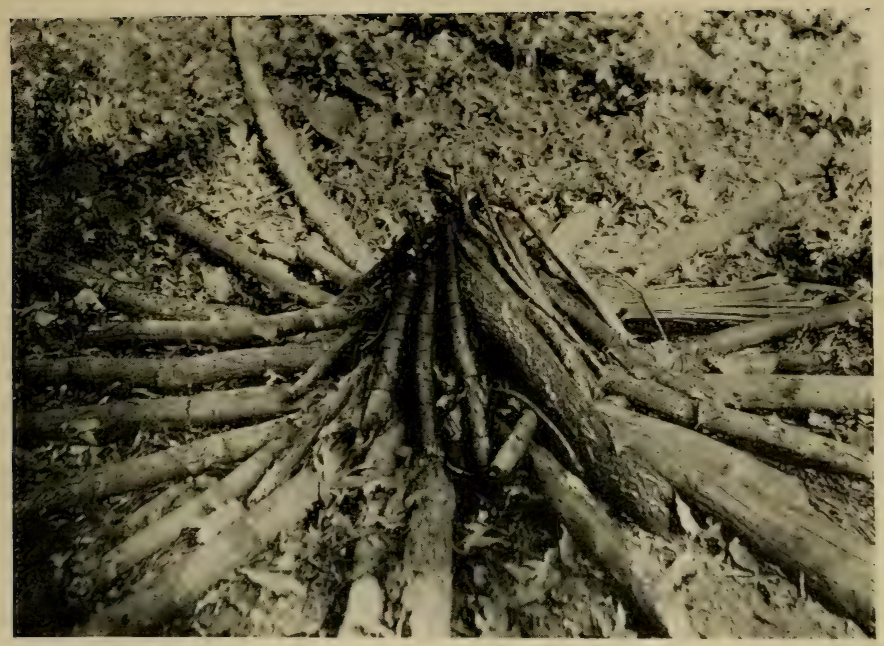

THE IXDIAT FIRE

A good model for a friendship fire. The poles are simply shoved in towards the center as their ends burn away.

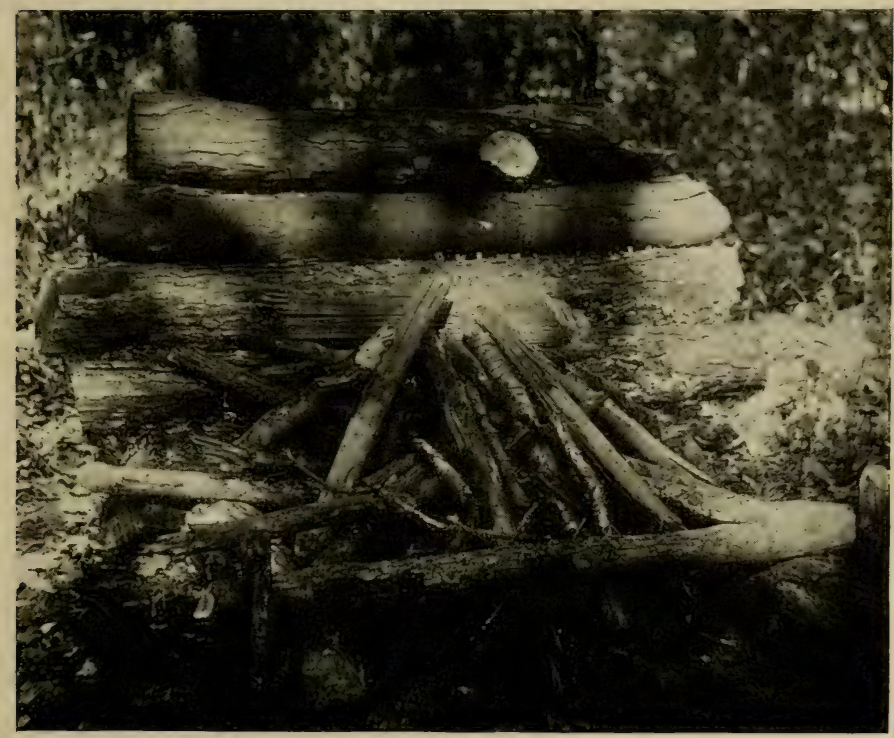

THE NESSMUK BACKLOG FIRE

The best fire for heating an open tent. In boy's size 4 - and 5 -inch logs of red oak or green balsam, or green pitch pine, three feet long, are plenty big enough for a night fire. 

see comfortably the match is applied, and immediately you have a flame six feet high which floods the camp with light and warmth, dries out the dampness from tents and bedding and gives a fine place to eat in front of. You need give it no attention for at least an hour, when the second charge is put on and the party settles down for after-dinner stories, council and preparations for bed. Then, about nine o'clock the last charge is put on, and the party turns in and is soon asleep in the ruddy glow of the fire, while its heat rays far into the night will be reflected down upon the sleepers from the tent walls, - the finest, heathiest sleep known to mankind.

Next morning the ruins of the backlog fire are made over into a Chinook fire. There are a few embers left buried in the ashes; pieces of dry stubs charred at the ends here and there, maybe three of the backlogs, half charred through. The Chef reorganises this to make a Chinook fire as in the illustrations. One $\log$ is laid over the andirons in the place of the former forestick, with its charred side down. The other two are laid side by side a short distance behind this one, and a fire started under them. It is fed with sticks of birch to make it go, and maple to give it coals that stay alive. Two uprights are set up over the rear 
pair of logs, a cross pole lashed to them, and the coffee pot and fruit bowl hung over them to boil. Fish, bacon, etc., are done in fry pans sitting on the two rear logs, and meanwhile cookie has gotten his cornbread batter or biscuit dough ready in the mixing pan. The fire has reached over and set the forward $\log$ all aglow underneath, and cookie helps this along by raking out a bed of live coals under it. At the same time he scoops away a hole from the ashes and dirt in front of the forward log and into this he rakes more coals. The batter or dough is next set in the largest fry pan and set to bake in this hole, tipped up at about forty-five degrees, getting heat underneath from the live coals (which should be covered with shagbark hickory or hemlock bark to keep them from burning the bread) and at the same time it gets strong heat from the glowing log overhead which is kept going by the fire under it. Such is the Chinook fire, one of the best breakfast fires ever devised.

Let us return to the night before and look over the labours of the chefs at the evening meal. As this is THE big eats of the day, they have a stew on, broiled meat, tea, stewed fruit, boiled rice or potatoes, and bread to make, and so the fire used is of great interest. Undoubtedly the most con- 


\section{CAMP FIRES}

venient range is the wire grid, such as comes separate from the outfitter's in the $9 \times 14$ inch size for 50 cents (or get half a broiler spider from the tencent store), or the grid which comes in the Stopple kit. The best fire under a grate that I know of is a crib of split sticks of green blackjack oak, the little oak with the clubshaped leaf which grows in thickets. It gives almost no flame, plenty of heat and lasts a long while. The Firemen of the camp see that the cooks are well supplied with this, all split for use. Just as good is hickory (not the shagbark which is too valuable for its nuts to waste on firewood) and after that, hard maple and the chestnut and white oaks. Lacking a grate the regular camp fire with two uprights and a cross pole is good. It is usually shown with crotches, but as these are hard to find and harder yet to drive into the ground, straight stakes are better with the cross pole lashed to them with pieces of copper wire. The woodsman's pothooks come next, made of forked branches with the lower end notched with the penknife to take the pot bales. Another good pothook that is adjustable can be made by any boy by getting ten cents worth of brass windowsash chain, cutting into 18 inch lengths, and putting on hooks at each end. These are hooked over the 
cross pole at any height desired by simply putting in the hook at any link in the chain that it comes at when thrown over the pole. The lower hook takes the pot bale. Under the cross pole go two logs of one of the unburnable woods, red oak, etc. These must rest on short billets under their ends or there will not be draft enough to keep a good fire going, and are best staked in place so that an inadvertent kick in passing may not displace the logs and tip any fry pan resting on them into the fire. For a midday "bilin' th' kittle" the crosspole is dispensed with and its place taken by a dingle stick, simply a long slender green pole stuck slantwise into the ground and held firm by two forked stakes a foot long driven in a short distance from the rear end. At its outer end hang the pots and as each new one bends the pole lower this must be allowed for in cutting pot hooks. A pair of parallel logs under the pole lengthwise of it, confine the fire within bounds and give a place to set the fry pans.

For baking with the reflector baker you want a high fire; in a dutch oven made of a fry pan with cover, a bed of coals protected by bark chips and a bright fire built on top of the pan. For the former the easiest way to get a high fire if you have a grate is to simply set a blazing log on top 
of the grate on one edge. The fire below will keep it going and its own flames will add greatly to the height of the fire. If no grate, drive in two pairs of small stakes 18 inches high and 2 inches apart. Fill in with short billets until you have a backstop a foot high. Build a high hot fire in front of this, with the sticks leaning upright against it. This will give you a flame thirty inches high with most of the heat up above, and is the only way to get biscuits browned on top before the bottoms burn. And remember that unless the reflector baker is clean and polished inside it will not bake at all. A sooty baker simply burns the good dough!

Occasionally, especially in midsummer camping, no hot fire is wanted for the main fire, but lots of light would be very acceptable and cheerful. For this purpose collect a lot of short dry sticks and split billets and build of them a crib of sticks laid in rows an inch apart, the next layer at right angles to the one below. The first three layers of this are to be just the outer sticks alone, like a log cabin, and the starting fire built inside. Touch this off and you will have a bright flaming fire of little heat. Good for council fires and going-to-bed fires. Another good one for midsummer is the Indian fire. All the dead saplings that 
can be pushed over are dragged to camp and arranged in a ring like the spokes of a wheel. Over the ends of these is built a pyramidal fire of dry sticks and touched off at dusk. As the embers and coals of these heap up on the ends of the saplings they too take fire, and, as they burn away, are fed in towards the centre. Like everything else the Indians do it gives the maximum of results with the minimum of work!

Let me conclude with dangerous fires. Some woods pop so that they are continually filling the forest with live coals and burning holes in the tents. Such woods are hemlock, the two cedars, chestnut, balsam and spruce, and all the soft pines. To qualify as Able Fireman a boy has to know almost as much forestry as the cookies have to know chemistry, so if you elect that job in camp, don't take it over without enough preliminary study in tree identification and axemanship to make good. And, when the camp is broken, it is the Fireman's duty to see that the fire laws are complied with. That fire must be out; not dead, but OUT. It will not do to kick it about and put dirt on it; just poke about in the duff with your thumb if you are not convinced that a few live coals are still alive. The only thing that will put it absolutely out is water and lots of it. Drown 
the site. I've known a fire, left for "dead" to hold One Spark, which in two days became a smouldering heap; a wind sprang up, blew some leaves on it, blew them off again (lighted), andset the forest afire! Some States have fire laws requiring a permit from the warden before going into camp and the Fireman should see to this permit before the party starts. If there is much leafage and duff about build a ring of rocks around the fire site, and always clear the site for several yards around before permitting any fire to be made. We once started a fire in a nice ravine for the midday lunch and before any one could say Jack Robinson that whole ravine was ablaze with burning leaves, requiring the united efforts of the whole tribe to get it under control and out again. Fire is the Forest's worst enemy, and as the Forest is your Big Friend, see that your fire never harms it! 


\section{CHAPTER VII}

\section{WOODSMANSHIP}

The boys of to-day are re-learning the ideal of the Indian. When I was a boy we openly adored Cooper's Indians, the noble Uncas and his stern father, Chingachgook. We took them to heart as our ideals and named ourselves after them and tried to live up to their examples. Then as we grew older we were told that the noble Red Man was a pure fake; that in reality he was dirty, lazy, savage and cruel, and that Cooper's word-paintings of him were a gross exaggeration. We now know that these base calumnies of the Red Man were industriously spread by those mainly interested in taking his lands away from him, aided and abetted by such historians as Parkman who judged only from what they saw as travellers coming into contact with the worst specimens of the race. But still our boyish ideal of Uncas and Chingachgook persisted; if the Indian was not like them in reality,--he ought to be, with such a glorious life to lead! and now we learn the truth from the neglected writings of such men as Catlin and 
others who lived with the early Indians, and again from such early plainsmen as really knew and appreciated him.

For he was the Spartan of the New World. His art is the only so-called savage art that endures modern criticism; his religion was singular in its simplicity and nobleness. He prayed daily for Courage, Truth, Honour and Chastity, and what boy of to-day could ask for more! For, with these four attributes of character, all that is desirable in this life will be added. The Indian's mode of life appeals to all boys; his ideal that since the Great Spirit is in everything then everything, even articles of daily use, should be made beautiful, appeals to boys and finds ready expression in the decoration of tents, accoutrements, rifle and equipment. And so, to boys and most outdoorsmen, comes a desire to know the primitive woodcraft of the Indian; how to make the rubbing stick fire, the stick bed, bark shelters and utensils, basketry, ropemaking, bow and arrow and fishing tackle, wilderness foods and cooking utensils-all that comes under the name of woodsmanship. Mr. Ernest Thompson Seton, who has done so much to restore to common knowledge the art and character of the Indian, has set all these things down at length in his "Book 
of Woodcraft." As I have used and made most of the things there described, since early boyhood, I will run over them briefly in this chapter. My equipment was, for the most part, copied from real Indian specimens in the big Museums, which I used to haunt whenever in the City.

To begin with the rubbing stick fire. Every boy should know this simple trick; most Boy Scouts learn it as part of their regular instruction. Given a shoe lace or thong, one can kindle a fire even if lost in the woods with this knowledge tucked away in the brain. Nature has supplied at least one tree in every woods that will give suitable wood for the purpose, and this in every part of our big country. For the West, dry cottonwood is the thing; Pacific coast, red fir; our Eastern woods, dry balsam, linden, red and white cedar; in the South, cypress. Even dry white pine will answer, provided it is not too young and resiny. What is wanted is a wood that is soft fibred, free from natural lubricants like resin, and capable of producing a fine charred dust under friction. Of your wood, make a drill a foot long and an inch thick, pointed at the lower end, and whittled to a shoulder and pinion at the upper end. The drill socket that fits over this pinion must be of some hard wood, preferably a pine 
knot which furnishes its own lubrication. For the fire board split out a flat piece of the same wood as the drill, cut a notch in it half an inch deep, and start a shallow cup with the penknife just beyond the point of the notch. Next you want a bow. Get it out of some stout springy wood like young hickory or a branch of white oak. Fasten your thong to both ends of it just tight enough to make one turn around the drill, gripping it tightly. Now some tinder, which can be made of a strip of cedar bark crumpled and broken with the hands, or of shredded and powdered birch bark, or crumpled fine dry grass. Now put a small chip under the notch in the fireboard, set both on the ground, put your left foot firmly down on it, put the point of the fire drill into the shallow cup at the tip of the notch, and start revolving the drill with long strokes of the bow. As you bear down on the drill socket with your left hand, the cup is reamed out into quite a hole, and presently smoke begins to come out of it. Now put on more speed, keeping the pressure about the same; when the smoke comes in dense clouds with yellowish tinge and there is a little hill of black dust in the notch, take away the drill and fan gently with your hand, not your breath, for the moisture in it would put out the spark. A thin column of 
smoke is ascending from the pile of dust, and if this persists you have the spark down inside and can raise chip and fireboard together and blow gently on it. Soon it has grown into a small live coal and then you take away the fireboard and put your tinder gently down on the pile of dust and live coal and blow gently on it. As soon as the tinder takes, blow hard and soon you have the flame. Linden is the quickest wood; the world's record so far as I know, is held by Dr. Joe Root of Hartford who got flame in 27 seconds from the word "Go!" Seton's record is 29 seconds when last heard from; my own, one minute and fifteen seconds, but I have not tried for speed. I am more interested in finding woods that will work, for in the Middle Atlantic States balsam is hard to find, linden is very rare and most of the woods are filled with oaks, maples, gums, pines and hemlocks, none of which will get the fire with any certainty. Cedar is the easiest wood to find; it takes lots of strength to get a fire with it before one tires out. The secret is to call up your last ounce of energy just about when you are all in, and "give her both barrels" at the end of the drilling.

The Indian stick bed is another primitive bit of woodcraft that appeals to boys. It is the lightest 
and most comfortable bed to carry on the trail, and rain cannot hurt it. I made several of them before I was satisfied. Seton's beds have too large sticks and too far apart to be very comfortable without a mattress, and as I had no use for any bigger mattress than a deerskin weighing under three pounds I made my bed of small sticks only three-eighths of an inch in diameter. The best woods are sour gum and pin oak, the reason being that these will bend but not break. In such narrow sticks as these your weight will let your hips down, but that is better in the long run than carrying a heavy bed of sticks stout enough to hold you up all over. The stick bed is rolled out on a couple of straight poles six feet long, and stretched to two stout cross pieces staked in place at the ends of the poles. Under where the hips come I put a pile of browse or leaves and let her touch; all the rest of me is held up springily at every point. To make, you need six strands of the smallest hemp rope about eight feet long. Whittle a fid of hard wood, something like a small marlinspike. Start the bed with a stout rod fiveeighths of an inch thick which is rove through the strands of the ropes, opening the strands with the fid. Lash with fish line at all six points. Now work in about seventy of the $3 / 8$ inch rods, spacing 
them not over $3 / 4$ inch from centre to centre. Each must be lashed at all six ropes to stay in place and not bunch up the strands of the rope. Finish with a second $5 / 8$ inch rod, laying all the others butts to tops alternately. Even bent and crooked sticks will straighten in threading through the rope, and when done you have a bed 24 inches wide, five feet long that will weigh about $3 \frac{1}{2}$ pounds and roll into a package 5 inches diameter. On the trail I roll it out and stake fast as described, covering it with a thin layer of hemlock or pine browse or even dry leaves, and then on that roll out the sleeping bag. It makes a fine, springy bed and you are asleep on it in no time. For decoration, dip half the bed in red dye made of boiled dogwood roots and the other half in black dye of bark of the white oak boiled with a nail in the pot. Add also a head piece of canvas, painted with your totem, and a suitable Indian border (see museum for decorative art) and put in it three rows of pockets to hold your small valuables when asleep especially the things that may be wanted quickly at night, such as your match box, electric flasher, watch, and pistol if in a wild game country where small animals come sniffing into the door of the tent of an early morning.

Another good bed, that can be made up in an af- 
ternoon if on a permanent camp not likely to be soon moved, is the grass mat. Make a loom of twine warps spaced three inches apart, each ten feet long. All of these (there will be eleven of them for a 30 -inch wide bed) must be fastened to a head string lashed to the head stick of the loom, which is pegged out some few inches above the ground. Half of the warps, alternately are to be pegged to stakes a foot high stuck in the ground at first about four feet from the head stick. The other half of the warps are tied to a foot stick which can be raised and lowered by the second boy on the job. All these warps come up and down between the ones fastened to the pegs, so that in raising and lowering the foot stick you cross the sets of warps. Get a quantity of grass and make it into bundles or sheathes some two inches thick. Start the first sheathes with the foot beam raised, and ram them home tight against the head stick. Now the beam boy lowers his foot stick, thus crossing all the warps and imprisoning the sheathes in place. A second set of sheathes is now rammed home against the first, and again the warps are crossed by raising the beam. This is kept up until you have woven a grass mat two inches thick, thirty inches wide and five or six feet long. Finish by tying all the warps over the last sheathes of 
grass and securing them in place with a foot twine so that they cannot slip sidewise.

Another bed for a one-night camp or other short stay camp where you have not much time to spend on bedding is the browse bed. Climb the nearest hemlock, white pine, or balsam, and lop off a dozen bushy lower limbs. It will not hurt the tree much, for these lower limbs are bound to be shade-killed in time anyway. Chop off your browse branches about a foot long. To carry them to camp in a woodsmanlike manner, cut a stout sapling four feet long with a crotch or stub at the lower end. Stick this upright in the duff and hook your browse branches around it by their big ends, laying each layer in a circle. Soon you will have a furry caterpillar of green browse of approximately the diameter of two browse branches and as high as the stick. Carry to camp like an old-timer; one stickful is enough for one bed. Lay the browse carefully with the big ends down, shingling from head to foot of bed. Spread on ground cloth or poncho and then your blankets or sleeping bag.

Another woodsman's tool that every boy likes to carry is the maple or cherry knob cup. These knobs are formed by the tree over old branch stubs. As the branch is shade-killed it dries and 
rots close to the trunk and the winter winds break it off. Season by season the bark creeps over it until finally the tree has buried it deep with layers and layers of new sapwood until there is a knob formed. Saw this off close to the trunk, and choose a big deep one while you are at it, for they are much smaller than they look outside. You will find the rotted powder of the old branch stub at the heart of the knob, and a lot of hard heart wood surrounding it. Bore holes in this with an auger bit, getting out the bulk of it by so doing. Now start with a gouge and begin shelling out the layers of sap wood. You will find that the knob consists of a regular series of these sapwood layers about an eighth of an inch thick. These are all to come out except the outer two and it is surprising how easily they spall out if you get right at the knob before the sap has had a chance to dry. I have made a knob cup within two hours from the time I began to saw off the knob (which, by the way is the hardest job of the lot). Your penknife will pry off the outer bark, but augur bit and gouge are the better tools for the interior. Stain, varnish or shellac outside, but do not put anything on the inside, for some liquids dissolve the shellac, and hot water is sure to make trouble for any inside finish. A leather thong and small 


\section{CAMPING FOR BOYS}

maple barrel suffice to fasten the cup through your belt over your left hip. I usually replace the barrel with some such useful appendix as a snipe whistle or dog call.

How to travel in the woods is a subject not often written about, most writers for boys overlooking its importance. Your veteran woodsman swings along hour after hour, noiselessly, easily, quietly, while you flounder and get into all sorts of difficulties. How does he do it? In the first place, by the way he handles his body. He has the woodsman's swing to his hips, not stiff and rigid like a man on a country road, but limber and flexible, his body always in perfect balance, so that no muscles are exerted in keeping himself on his feet. Keep an eye on this detail when next you travel in the woods, and keep it up until it becomes second nature. Let yourself go, loose and easy, don't strain and don't be in a hurry. Your eyes are always busy, not only in picking out the best going ahead but in searching every vista ahead for game and wild things. Of two possible routes always take the upper, for low lands in the woods always mean swamps, briars and hard going. Skirt around these rather than try to force through them, for they will always get worse as you go on. If into such country inadvertently, work towards higher 
ground. In running a line by compass do not try to steer yourself like a ship by it, but stop every few hundred yards and pick out a prominent object like a burnt or dead tree, a big one, a crooked one, a rock shelf, anything that you can set out for, and work over to it no matter how much detour you have to take to get to it. Once there you are on your course again, and can stop and pick out another prominent object ahead on your direct line. Thus you can run an absolutely straight line, whereas if you tried to steer yourself by compass you would have to change your position so much, owing to detours and obstructions, that your course would be a long crooked one, trending far off the correct line from where you started out.

In following a blazed trail, never abandon one blaze until you have spotted the next one ahead, and don't take a spalled piece of bark for a blaze no matter how good it looks, for to lose your blaze is to lose the trail, and your chances of finding it again are slight. Two blazes on a tree, one above the other, usually mark some object of interest or are a trap or cache sign, but if two blazes are on opposite sides of the same tree it means a turn in the trail, so watch out for the next blaze, somewhere else than in the line of your course. In 
stony country the blazes are usually small cairns of stones or short blazed stakes driven in along the trail. Here again a pile made in an angle indicates a sharp turn in the trail. If totally lost, do not follow a brook unless absolutely necessary, for its ways are devious and apt to be hard going. If you know the direction you want to go in cut loose from the brook and strike across the forest by compass. If your destination is a lake or river or valley which you are positive lies in a given direction, it will get you there much sooner and more easily than the brook, which is sure to take its own time. The north end of your compass needle is always black, but, in the panic of getting lost, every boy doubts this and isn't quite sure which is which - even a man tenderfoot can be bluffed into believing that the white end is north, as I have often tried it out on them when they knew very well that black was north! To avoid any such discussion, test your compass some day and scratch on the back of the case BLACK IS NORTH for this compass, date-so-and-so, for the other boy is sure to doubt it. The sun is a good guide, if you have a watch, for half way between the hour hand and twelve is south when the hour hand points at the sun; but, particularly in winter, the sun is so slow in getting over his course and ranges so far south that to 
steer by him is apt to set you off your course, without a watch to check up south.

If the course leads across a swamp, pick out something prominent across the swamp on the course, and then work around to it. Don't try to get into that low ground, for you will just tire yourself out and get panicky and discouraged.

If it is a grey day and no sun and you have no compass you are in for some adventures. Lost man gun signals are Bang! Bang! Bang! and repeat every ten minutes, or even five. Three fires, raising smoke a hundred feet apart mean the same thing, and every woodsman within sound or sight will come to you. If no answer, follow a brook or climb a tree on top of a mountain, hoping to spot some familiar landmark from there. There is nothing in the average woods that will tell north, but, by averaging up many indications of where the sun has shone and left evidence, you can find south with some certainty. In the woods north, east, south and west are all alike-deep shade; so waste not much time on moss on north sides of trees and the like-there won't be any. But, when you come to an open spot where the sun has had a chance, then look carefully. Weeds will be growing thick in front of a rock that faces south, with shade-loving weeds, if any, and moss 
on that side if the rock faces north. Lichens will be burnt and scanty on the south faces of rocks but abundant on the north faces, and again the moss. Weeds and brambles will be thick under the trees edging the open facing south, while they will be absent or scanty under the north-facing trees. All the bushy branches will lie to the south, those pointing north will be stunted and gnarly. Hemlocks in the open will have their tips bent to the east or northeast, and sweet gums will have most of their burrs strewn to the northeast by the prevailing southwest winds of autumn. Finally, on a grey day the wind is generally east, northeast or southeast.

Once having gotten north with reasonable certainty, don't rush off and lose it again, but keep it like you would a spark of fire, with the greatest care. Pick out a big landmark that can be seen from any tree top and work to it or away from it as your course may direct, and whenever you lose north again, climb a tree and find the landmark.

In a word, don't race, don't get frightened-it is the camp that is lost, not you-and work at the problem with all your brains, making them save your strength and legs instead of wearing out the latter in foolish going just for the sake of getting somewhere. It is better to stay where you are than to go away from camp. 


\section{CHAPTER VIII}

LIVING OFF THE FOREST

Boys are much more apt to need a meal from forest foods than even men hunters and trappers. For instance, you start for a hike in the forest; you intended to get back about noon, but before you know it it is noon and there is lots more that you want to explore-if you could only get a bite to keep you over midday, and so make a day's hike of it. You wished that you had brought along some lunch, but that is too late now; can't we find something edible? Well, there are literally tons of food all around you, and it is part of woodsmanship to know how and what to eat. In midsummer the natural lunch will be berries, frogs and fish; in the fall, nuts, rock tripe and game, and to get the latter we use the same tools that the Indian did before the white man was ever heard of.

One preferably hikes in the woods from September on, for the insects then have subsided somewhat. September is practically summer, except that berries are ripe and the fish are still in evi- 
dence. I once caught a brook pickerel with no other implement than a beech broom. He was motionless at the head of a shallow pool in a brook and I needed fish for breakfast. Cornering him in the shallow water, a few quick swipes of the brush swept him out on the rocky brook bed, and before he could hop back he was pounced on and was soon baking on a stick before a fire. But a better way to catch all small fish is to build an Indian fish weir. Cut a lot of small shoots of red maple or arrowwood or even elder. Bind them into a flat net by twisting greenbriar or wild grape vines with two or three of these twists crossing all the sticks, and one stick between each twist. Such a net will be two feet high, say three feet long, and all the big ends of the sticks will be downward with a twist of vine along the bottom, and a second about a foot higher. With this you make a fish trap. Find a small pool, down below a larger one that is full of fish-trout, sunnies, chub, dace, even minnows and catties-and set this net across the downstream end of the smaller pool. See that it is carefully chinked with mud and stones, so that there is no way for the water to get through except through the stick. Now fix up the upper end of the pool so that it has a narrow clear channel to the upper pool and set aside a big rock that will 


\section{LIVING OFF THE FOREST 271}

securely close it. Next, go up in the upper pool armed with brushes and wade in, scaring all the fish down into the little pool. Many of them will hide under rocks, etc., so be thorough in clearing the upper pool. Close the lower with your stone, cut a new channel for the overflow water, and you will have a whole aquarium of fish in the trap, most of which can be caught by hand or it can be drained dry by mudding the rock so no more water can come in.

For game, the bow and arrow is always good, and every boy should know how to shoot one. So long as you have a shoestring on you and there is a branch of oak, a hornbeam sapling or a young cedar you have your bow. The arrow is the important thing. Most young shoots of maple, chestnut and viburnum or arrowwood are plenty straight enough, but no arrow will fly anywhere near straight unless it is feathered. Make these of birch bark or even a tassel of shredded barkanything that will take the air currents and make the arrow fly head first. For a head the simplest point is just whittled and fire burnt. In using the bow the Indian's way of getting right on top of the game by his woodcraft before expending the shot is the only thing. Your easiest game is the confiding little chipmunk, and after him come such 
birds as robin and flicker, both of which are fond of wild cherries and dogwood berries. Sitting concealed under such a bush they will come not two arrow lengths away and can hardly be missed when the fatal shaft is loosed. In the North one can get almost as near to partridges, and the two squirrels are almost as unwary. Of course in the case of a starving lad, the game laws have to be temporarily suspended but otherwise some of these birds must be let severely alone. To have a bow that is all of your own woodsmanship the thong also must be woods-made, and the best thong I know of is the bast rope, made of a young mockernut hickory sapling. Cut this down and peel off the bark, which will come off like a glove any time but in winter when the sap is down, next slit the bark into three long strips an eighth-inch wide. Now knot these at the upper end, and plat a three-braid rope of it, adding more strips to each length as required. Three strong men cannot break such a rope, and it is flexible and knots readily. Makes a good lasting bowstring. The Indians fletch their arrows by splitting a feather and tearing off a little of the feathering at each end of the quill so as to get some three inches of vane. Three of these vanes are then lashed on with fine deer sinew. The point is made of a long 


\section{LIVING OFF THE FOREST 273}

piece of some heavy hard wood, such as locust, pin oak or persimmon, pointed, polished and fire-hardened, and these make good arrows for small game. Only do not waste them on game that is more than ten feet away!

To cook all these things the easiest is to split and broil before a bed of coals on a sassafras fork. Some one may have brought along some tea or a couple of potatoes or in some forest cache there may be some flour and a packet of baking powder. To cook these requires boiling for fifteen minutes for the potatoes, or steeping four minutes for the tea. The best way I have tried is with a maple log bowl, cut from a six inch billet two feet long. In this I dug out a long shallow hole, like gouging out a boat, using only the axe and hunting knife. It held a quart of water and to boil it I set a dozen stones as big as eggs over the fire and let them get white hot, that is so hot that they were fire-clean with no soot on them. Five of these stones brought the quart of water to a boil, and each stone thereafter kept the quart boiling for a minute. They were all put in at one end of the bowl, so as not to get the water dirty, and I made a fine erbswurst soup out of a teaspoonful of the powder. Another way is to cut a square of birch bark about a foot on a side, flex it over the fire, and bend to a 
rectangular boat skewing with sticks. This can go right over a bed of glowing embers and will come to a boil if you keep blowing on it. All the bark above the waterline will take fire and soon dip and spill the soup unless you reinforce it inside with a twig rim in contact with the liquid.

To make woods biscuit, cut out all the fat on your birds or squirrels and try it out in a shallow birch-bark bowl or a rock with a hollow in it. Mix this tallow with the flour and baking powder and form into a ribbon of biscuit dough about two inches wide and half an inch thick. Wind this around the end of a two-inch diameter maple stick which has been peeled and set over the fire until it is screeching hot and then lean it over your coals until the biscuit has been raised and browned. Peel off and eat as you go. This is the woods "Club Bread."

What is left of your fat will do to fry puff ball mushrooms with. The regular field mushroom does not grow in the woods, and all the deadly poisonous ones $d o$, in the greatest abundance, so the best rule is to let them all alone, for you do not know you are poisoned until over twelve hours later when it is too late and no human aid can save you. However, no one can mistake the puff-ball. It has no gills, no umbrella, nothing that a poison- 


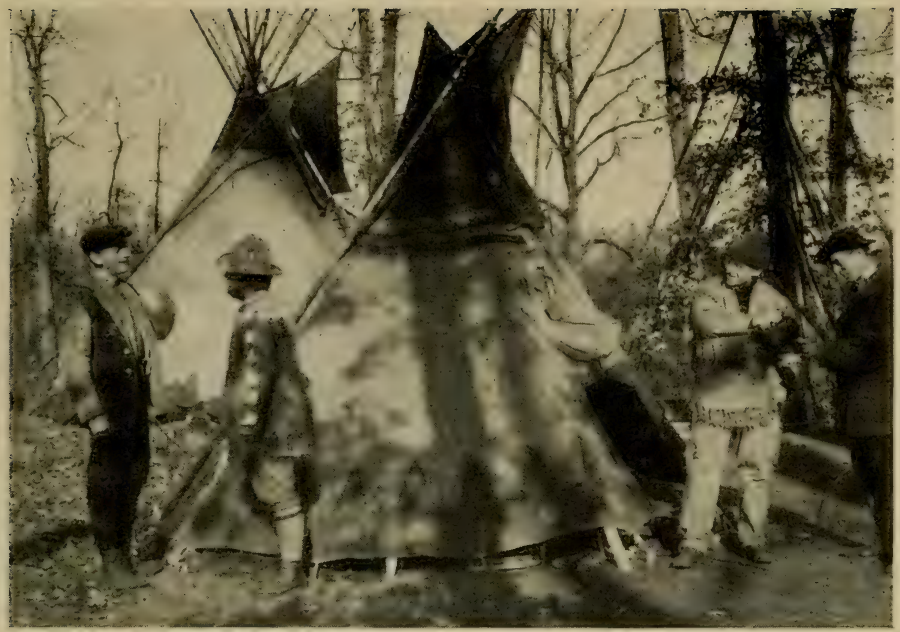

THE INDIAN TEEPEE

An encampment of the Red Lodge. The teepee malies one of the best and most picturesque camps for a crowd of boys. A good base for a permanent camping organization.

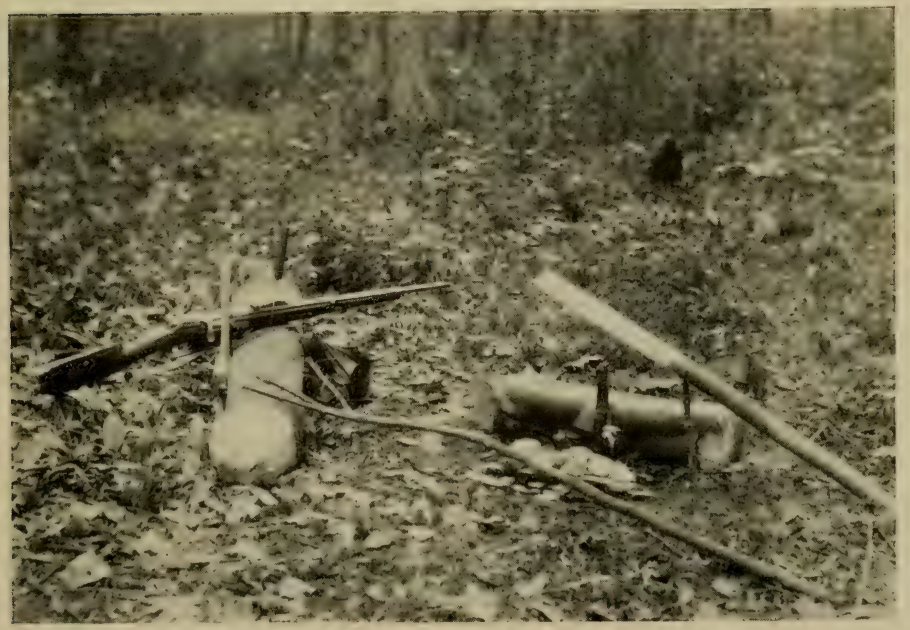

A PRIMITIVE COOK KIT

Maple club biscuit baker, log soup bowl, hot stones for boiling soup, and sassafras broiling fork with wire broiler. 

ous mushroom has, and it looks like a big leathery pear. Do not pick little ones, they may be just the cap of some deadly species. But a big one is all solid white inside, and you slice it and fry or bake on a smooth flat stone. When fully ripe and full of puff powder it is one of the best punks for carrying fire in the woods, for a coal embedded in it will keep for hours so that you can move your fire in a puff-ball with ease.

Rock tripe is the only other fungus I would eat on a bet, and it also is unmistakable. Growing on most rocks in the woods you will note a quantity of black ears, round as pennies and curled up off the rock. Pick these and dry thoroughly over the fire, for they will physic you otherwise, and then boil in the log bowl for half an hour. Resulting dish tastes like tapioca and is edible and nourishing.

Of course the most sustaining of all raw forest foods are nuts. No flour in the world can compare with them, as you can easily prove by taking along a pocketful of them and munching them during your hunting trip whenever you feel faint and in need of sustenance. Chestnut has the most meat for the least work, and after him comes shagbark hickory, black walnut, butternut and hazel nut. The most sustaining fruit of all is the persimmon; its only rival is the date of the Orient, 
both of them having almost as much protein as meat.

I might digress here for a few observations on woodcraft in hunting. Do not stick to forest roads, nor yet just tramp along; neither way will net you much game compared to real intelligent hunting. Put yourself in the animal's place; what would he naturally be doing at this hour, and what is he feeding on? These are the two great questions. Grouse love dried huckleberries, though they will not touch them when they are plump and juicy; they love dried wild grapes that have fallen to the ground, weed seeds, beech nuts, and, oh dear-how they love cranberries! Therefore open the crop and stomach of the first grouse you kill that day and see what he has been eating. Thereafter search those spots and let the other fellow just tramp along. When you come to a spot where one is likely to be, rest assured that he is watching you and will jump the instant he catches you off guard. If you whistle a little low tune he will linger a trifle longer than usual, but, whatever you do, do not make a single move without being ready at all times to shoot. Before putting your foot forward, look for a likely spot for it, and then feel for that spot without ever taking your eyes off the thicket, or bramble or grape vine just ahead 
of you that looks grousey. In the same way, be on the watch for woodcock in swamp bottoms, and for quail along the timber edge in the weeds and brambles bordering farm fields. Here they feed, and they are all crouched down and watching you as you move along. Kick every clump and brier patch for rabbits, and when you kick be sure to be in position to shoot. Haunt the oak ridges and dogwood thickets for squirrels. Their favourite food is acorns and nuts, with an occasional berry diet-it is wasting time to look for them in a maple or birch thicket. That is real hunting, not just blundering along.

And be always on the lookout for tracks and sign. Pass no sand patch or mud bank without examination. Muskrat leaves his little claw marks with no palm; mink, all five claws and a faint palm; 'coon, a tiny baby hand; squirrel, four tracks in a group with hind tracks in front of fore; rabbit, another larger group, usually with the front paw tracks set very close together making a three-track group of it; fox leaves the trail of a small dog, but it always registers, that is a single line of tracks like a two-legged animal, while the front and hind paws of a dog seldom register cleanly. Wildcat leaves a round four-toed-and-palm track larger than any cat and showing no claws. Quail tracks 


\section{8}

\section{CAMPING FOR BOYS}

are three-toed like small chickens, and grouse the same but larger. Watch roads, trails and stream banks for these tracks, and, if entirely fresh, stick around a bit and see what you can see. That means maybe half an hour of still hunting, but it will get you more game in that spot than just pushing right on, strong as is the temptation to do so.

When camped in a good game country in the trapping season, a good deal of game and fur can be added to the bag by setting a few simple woodsman's traps. Two woods-made traps suffice, one a springle for birds and one a deadfall for animals. The former is just a springy withe, bent into a bow by a string tied at the small end and held in a cleft in the large end by a short twig with a knife edge cut on it. The rest of the string is a slip noose lying on both sides of the twig. The bait is put at the end of the twig, firmly tied, and when the bird alights on it his weight bends down the twig, releases the string from its cleft, and the withe snaps straight, drawing the noose tight about the bird's feet. To make a deadfall, cut off a four-inch sapling about a foot above the ground, level off its top, and, with your axe make three clefts in it, forming three sides of a square. Into these are driven flat shooks, making three sides to your box. The rest of the sapling is squared off 


\section{LIVING OFF THE FOREST 279}

with the axe and cut about eight feet long. The squared end rests in your box and the other on the ground. The end of the log comes in the box and is held up as shown in the drawing by two triggers, the short one upright holding the log up and resting on the long one to which the bait is attached. There is no way for a little animal to touch the bait except by climbing up on the stump, with his head in the box, and when he pulls the bait, down comes the log on his head, much more humane than any steel spring trap and any boy can make it in an hour or so with axe and knife. 


\section{CHAPTER IX}

\section{PERMANENT CAMPS}

WHILE this chapter is primarily intended for older boys and men leaders who may be called upon to establish large encampments of boys for summer instruction and training, it also has its uses in the oft-occurring case where three or four boys elect to spend the entire summer, or at least a month, at some favourite lake, and a large tent with cots is contemplated. For a long stay, where a team takes you into the camp site and weight is of no importance, the big wall tent exceeds all others in comfort and convenience. Crowding it closely is the large teepee, which will sleep almost as many around its circumference and permits bright cheerful fire at night inside the tent. Also it appeals more to the romantio in boys-unless they happen to be militarily inclined when the wall tent will be the only bet. And the latter can be kept as warm as the teepee by the addition of a tent stove - a fine labour-saving device to cook on, by the way,-and one properly managed will give off abundant heat all night long. 
Plain duck army tents usually require a fly over them, or they will be apt to leak and will surely fill with a fine mist driven through the weave in a heavy thunder shower. Much better tents are furnished by the sporting goods outfitters, requiring no fly and also furnished in the various lightweight paraffined muslins when they give an astonishing amount of room and housing for very little weight. The $9 \times 12$ foot size of light special waterproof tent is very popular for permanent camping. It will sleep four boys easily, the cots being arranged lengthwise along each wall with a four foot space in between. It requires no fly and weighs 30 pounds, costing about $\$ 15$, so that if each boy chips in $\$ 3.75$ the crowd at once owns a fine forest home. It has no stakes and poles, for on any decent site such things ought to be cutable in the forest, the proper way to put up a wall tent being with a pair of shears at each end and a pole lengthwise between the shears to which the ridge tapes are tied - the way they do it in the Hudson's Bay country. A regular army tent with poles, stakes and fly, is a bulky nuisance, no less, and it costs a good deal more in the $9 \times 12$.

The 12 foot diameter by 101/2 feet high teepee will sleep five boys around the sides or eight to ten arranged like wheel spokes with feet to the 
fire, and it weighs 11 pounds in special khaki and costs about $\$ 14$. Because of its steeper roof it can be made of lighter canvas without any special waterproofing processes, as are used in the extremely light tent goods. A ten-foot diameter teepee can be made up for about $\$ 5$ by any enterprising set of boys who will buy 26 yards of 8-ounce duck and cut it into eight strips $3^{1 / 3}$ yards long. These strips are to be sewed on the machine to make a big square of canvas approximately 20 feet long by 10 feet wide. A semicircle is then struck on this cloth, ten feet in radius, and the canvas cut and hemmed. The remainder makes two nice flaps 4 feet on one edge, five feet on the other and about 24 inches wide. The four-foot edge is sewed to the teepee cloth and provided with pockets for the smoke poles. Such a teepee is to be dyed red or yellow, and ornamented with the totems of the tribe and later a pictorial story of the adventures of the tent in its various camps. A gang of four or five boys who study faithfully Indian lore and works on wooderaft will be able to follow the spirit of the Indian teepee life and have many enjoyable camps at it. Somehow it conduces more to the study of wooderaft and forestry than life in any wall tent, whose associa- 
tions lean so much towards the white man and the soldiery.

In either event I would not attempt a board floor for my permanent camp. It is expensive, difficult to transport and set up, and it precludes both tent stove and fire, so that it is in reality more conducive to cold and dampness than good Mother Earth under foot. A few camp mats of heavy 12 ounce duck or woven of grass should find a place beside each cot, leaving the rest of the ground free for the stove and eating table if the cooking is done elsewhere, as is usual in summer. In the fall and the early spring when the trout season opens, the nights will be cold and there will be more or less snow and ice, so that a fire in the teepee or in the tent stove means a lot of cheer and comfort. The main thing with a teepee fire is to avoid too much of it at first, so that the smoke flaps can carry off all the smoke made. Later, when a good bed of coals is established, the stunt is to keep three short fat billets on all the time. They last hour after hour, giving off much heat but no smoke, and when a deep bed of ashes is established and the last billets buried in them they will smoulder all night. Avoid a lot of small two-inch sticks which always have to be renewed and are always 
giving off much smoke. Dry six- and eight-inch logs, split in half, are the best teepee fire-wood.

For your wall tent the folding sheet iron stove, $10 \times 12 \times 26$ inches, weighing eighteen pounds, with two holes for cooking, is the thing. Go light with your fire at first or it will smoke everything out. The pipe comes up outside the tent, with the body of the stove inside and the front flaps held away from contact by withes. One cot should be set back in the rear alley when using the stove, making three cots in a row across the rear end of the tent, one on the forward left hand side and the stove and cupboard occupying the right front. Never close up a tent with a stove inside of it, for they all make more or less asphyxiating gas, and free draft for the air should be provided for. Once you have a bed of coals on the ground inside the stove you can add wood, a few sticks at a time and will find it a wonderfully handy cooker for the chef and fireman, as the stove eats very little wood in proportion to the cooking that it does. A one-hole stove is too small to get meals promptly on, but a two-hole will take care of almost any meal. The reflector baker is set against the side of the stove, which is red hot or nearly so, and will bake like a regular oven that way. Meanwhile the two holes have fry pan and pot going on them, while the coffee pot can usually 
be set to simmer somewhere on the sheet iron top around the smoke pipe. Such a stove will stand the crowd about $\$ 5$.

For berths there is the 80 cent wire cot with cheap mattress; the folding canvas tent cots, costing about $\$ 2.50$; or you can make your own cots by taking along each two yards of 8-ounce duck, lashing together a pole frame, tacking the canvas to it with 20 ounce galvanized iron tacks and resting the bed on two short log billets at either end. The Indian stick beds also do well, in permanent camps if reversed each day. They should have a mattress, which may be a muslin bag filled with dry leaves, pine needles or hay.

Once in camp, and sleeping accommodations provided for, set about making yourself comfortable in the matter of eating tables. It will do for the first meal or so to squat down with your plate on knees and cup somewhere on the ground, but, except in nomadic camps where there is no time to set up a log table, proper eating facilities are essential to continued comfort. The simplest is a stand-up table made of an old plank laid on cross sticks between four upright stakes. Its height should be about 40 inches. Next in order comes the sit-down eating table 32 inches high, with log benches 16 inches high on each side. This can be 
any dimension you prefer, but a long plank answers every purpose. Lacking a plank I have made very good tables out of two logs levelled off by filling with clean pebbles and sand and covered with a tarp or even birch bark tacked down.

As the crowd camps together, year after year, such comforts as folding tent tables and chairs can be added if a wall tent is the home, if a teepee, such Indian furniture as stools, headpieces for beds, etc., will be made, not forgetting the sweat lodge on the banks of the lake. In general the details of a permanent camp differ not greatly from hiking and hunting camps when a small party is out, but when it comes to handling a crowd of, say, one hundred boys, the conditions change materially. One of the best camps of the kind that I ever saw had the boys organised into eleven lodges of eight boys and a leader, each lodge having its own tent, $10 \times 14$ feet with eight berths and a central frame which had the clothes hooks for all wearing apparel. The berths were made by tacking canvas across a stout pine frame, with uprights at each end so as to get two-high bunks, four on each side of the tent. All trunks, suitcases, etc., were arranged down the centre of the tent underneath the clothes hook board. The tents were the standard army duck, with fly and board floor raised about a 
foot above the soil. They were pitched in a long row out in the sun, in a grass field; with a broad grass exercising ground in front where the blankets were spread out to air each morning. A central eating pavilion, a cook house and a teepee for the Big Chief and the leaders completed the establishment. This body was absolutely selfgoverning and self-sustaining, doing all their own work except cooking. The discipline was magnificent and highly beneficial to the boys. Each leader was held responsible by a system of "sinkers" and honours for the condition of his tent, and these "sinkers" meant something, toodeprivation of ice cream on Sunday for the whole lodge, for instance.

All the work of the encampment was done by the boys themselves. They built the council lodge, laid out tennis grounds, repaired roads and trails, prepared the food, set table, washed dishes, waited on table, built a church in the woods, painted and carpentered on the buildings, chopped wood, did all the work except that of two expert negro chefs. Every night at Council Lodge the leaders reported infractions of discipline, slovenliness, laziness, etc., and the Council meted out punishment in the form of "chump marks" - strips of surgical tape plastered on the bare arm and worn until work was 
done sufficient to deserve its removal. Part of the regular ceremonies of the Council Lodge was the string of boys coming before the Chief with bare arms proudly held out for removal of the hated chump mark (and teeth set to withstand the pain of its tearing off!) and other bare arms held out ruefully for the infliction of a mark. After which there were games before the council fire, plans for hikes and for the coming day's work, and by nine o'clock the night whistle was sounded and every Brave had to be in bed in fifteen minutes lest the Inspector catch him unawares!

Next morning at 7, from the Big Teepee would come the rising whistle and the whole camp would turn out in its pajamas for Army setting up exercises, after which five minutes for a dip in the lake and then fifteen minutes to dress and report for breakfast. After breakfast each lodge would spread its blankets in the sun and tidy up the lodge against the visit of the Inspector, and then set about its tasks for the morning. Those boys could do anything from grading a road to painting a totem pole.

At eleven the whistle sounded for the Big Swim, when for three quarters of an hour a hundred naked boys revelled in the waters of the lake, the 
younger ones being taught to swim properly by competent instructors. Then, grub; the report of the Inspector (consternation written on the faces of the Grey Wolf lodge over a "sinker" for a scrap of newspaper jammed in behind a trunk) and then the afternoon's play and study of nature under the leaders until five-thirty when again the dip in the lake. Boys were everywhere; knots of boys busy at this and that; gangs of boys hiking through the surrounding forested mountains ; little groups of boys on some special duty or other. It was a happy crowd, and the cost was but $\$ 6$ per week per boy. I had the pleasure of teaching them something of the arts of camping, forestry, and fly and bait casting, and it needed but some one to show them that there were game fish in their lake and how to catch them to give them the seventh heaven of satisfaction. Mighty few sick boys in that crowd!

Like most big camps of this kind, it owed its Indian spirit and organisation to Dan Beard and Ernest Thompson Seton, whose writings on the Red Man have been of such practical use to us all, boys and men. Like most of our natural resources we have wasted the Indian instead of conserving him. Certainly we whites could have 
much improved ourselves by grafting him on our stock instead of killing him off, for there is nothing that our nation is in so much need of to-day as the Red Man's simple virtues of Courage, Honour, Truth and Chastity. In a large camp, boys must have some ideal to work to, some underlying spirit with which to put themselves in accord. The encampment must be either military or Indian in its organisation. And it is the latter that by far the most appeals to the American boy. We have never been a military nation, and the absurd artificiality that causes a man to make a wooden monkey of himself before his ranking fellow-men in the name of military discipline smacks far too much of needless foolish restraint to appeal to boys. But the Indian's discipline, while quite as rigid, is much more logical and sensible, while the picturesque organisation and ritual of the Indian tribe, product as it is of our native land, is far more effective and workable in the fundamentals of human existence, life, liberty and the pursuit of happiness.

Personally there is no comparison in my mind between the Indian and the military style of encampment. The military has for its ultimate end the organisation of mankind for the grim purposes of Death; the Indian for the purposes of Life, for 


\section{PERMANENT CAMPS}

the most equal division of the common good so that none may lack and all share in the blessings which this good green earth so bounteously affords. 


$$
\text { H } 28484
$$







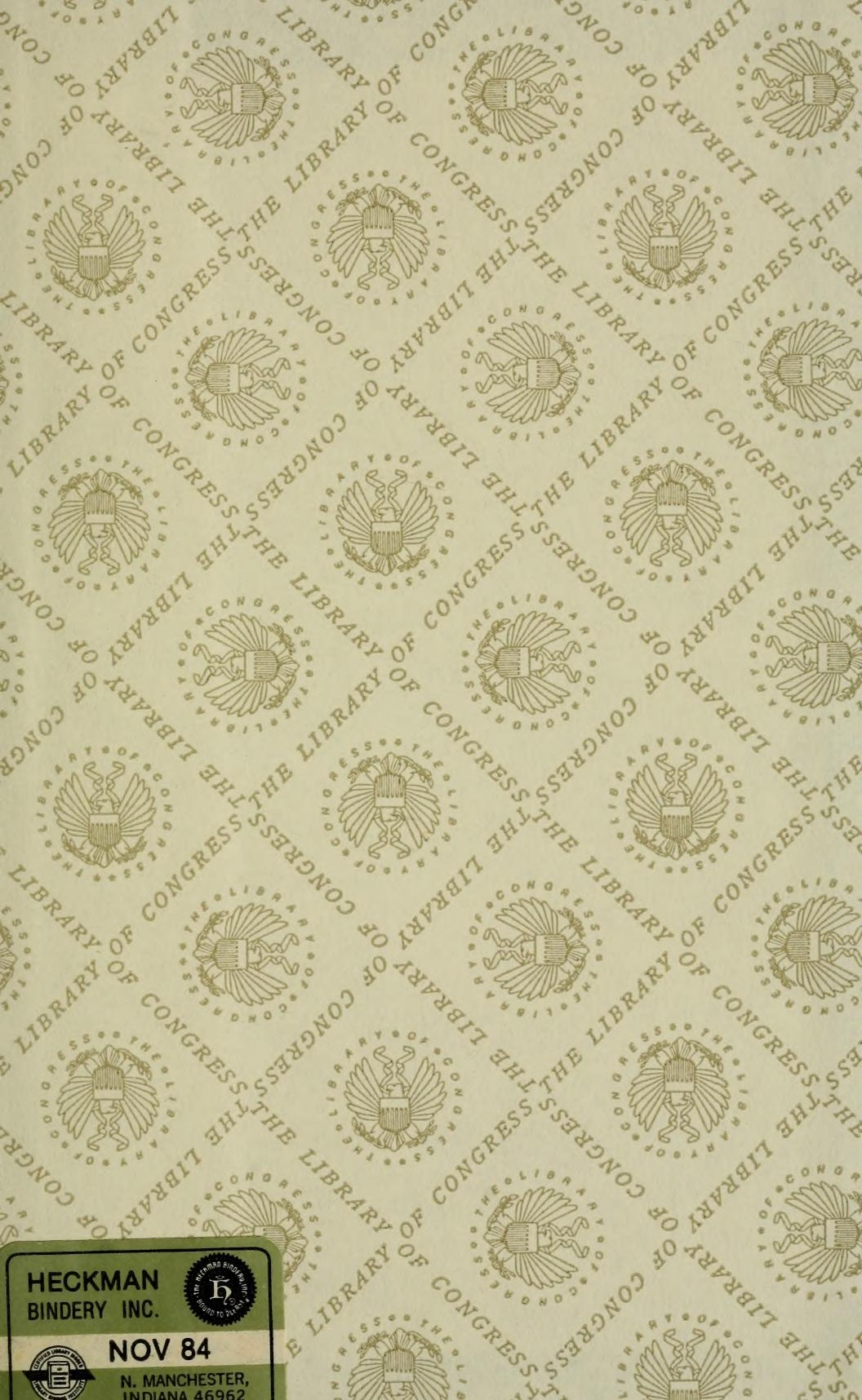


LIBRARY OF CONGRESS

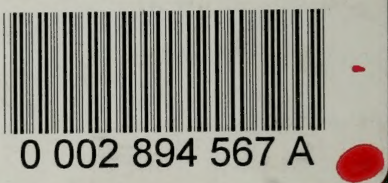

